
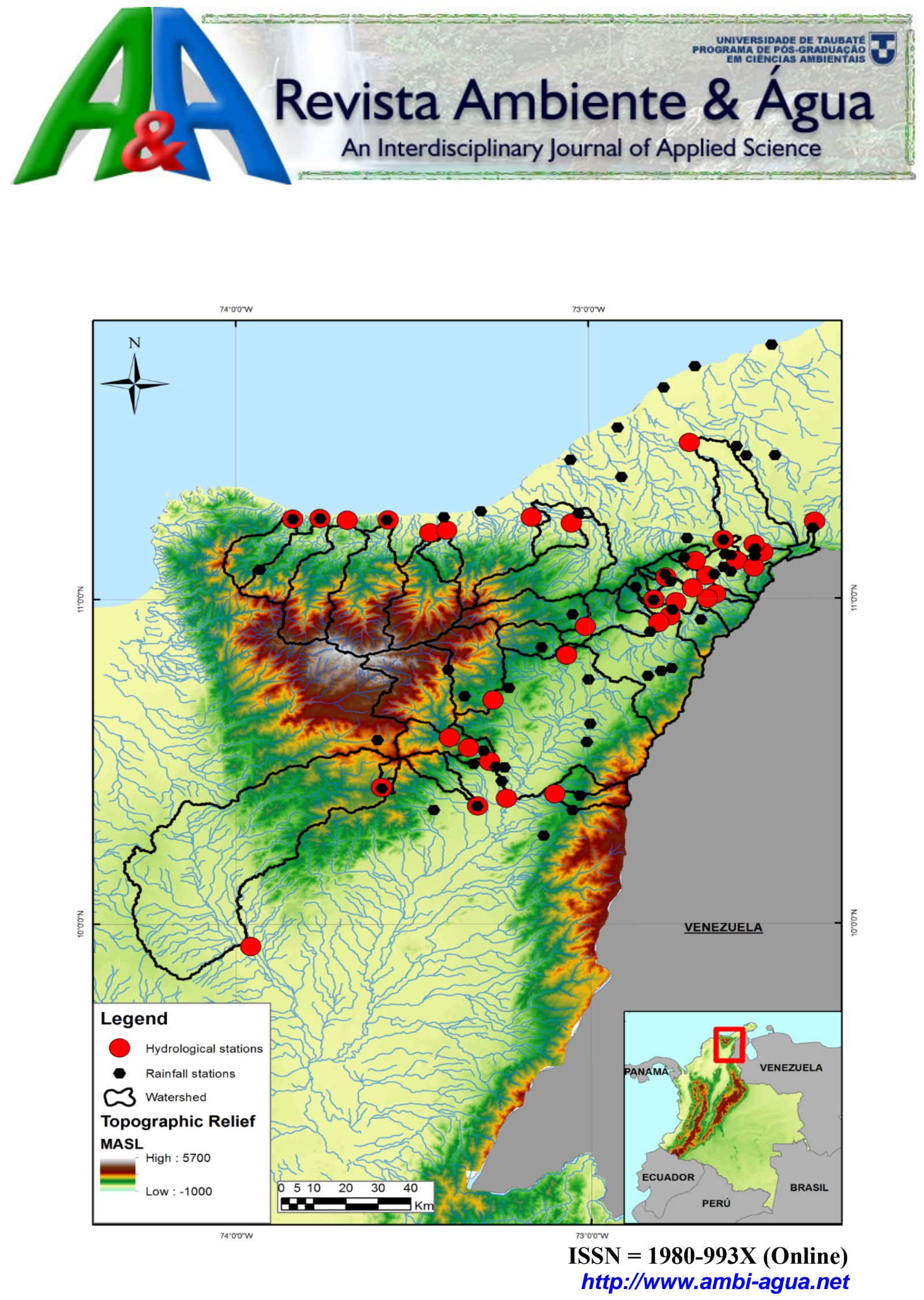

$38^{\text {th }}$ Edition of Revista Ambiente \& Água - An Interdisciplinary Journal of Applied Science, Taubaté, V. 12, N. 3, p. 351-512 May /June 2017. (doi:10.4136/ambi-agua.v12.n3) 
EDITORIAL BOARD

Editor

Getulio Teixeira Batista

Instituto de Pesquisas Ambientais em Bacias Hidrográficas (IPABHi), SP, BR

Amaury Paulo de Souza

Ana Aparecida da Silva Almeida

Andrea Giuseppe Capodaglio

Antonio Evaldo Klar

Antonio Teixeira de Matos

Apostol Tiberiu

Carlos Eduardo de M. Bicudo

Cláudia S. de C. M. dos S. Cordovil

Dar Roberts

Delly Oliveira Filho

Gabriel Constantino Blain

Giordano Urbini

Gustaf Olsson

Hélio Nobile Diniz

Ignacio Morell Evangelista,

János Fehér

João Vianei Soares

José Carlos Mierzwa

Julio Cesar Pascale Palhares

Luis Antonio Merino

Marcelo dos Santos Targa

Maria Cristina Collivignarelli,

Massimo Raboni

Nelson Wellausen Dias

Petr Hlavínek

Richarde Marques da Silva

Silvio Jorge Coelho Simões

Stefan Stanko

Teresa Maria Reyna

Yosio Edemir Shimabukuro

Zhongliang Liu Beijing

Editorial Section

Text Editors

Reference Editor

Layout Editors

Technical Support

Secretaria e Comunicação

\section{Associate Editors}

Universidade Federal de Viçosa (UFV), BR

Universidade de Taubaté (UNITAU), BR

University of Pavia, ITALY

Universidade Est. Paulista Júlio de Mesquita Filho (UNESP), BR

Universidade Federal de Viçosa (UFV), BR

University Politechnica of Bucharest, Romênia

Instituto de Botânica, IBT, BR

Centro de estudos de Engenharia Rural (CEER), Lisboa, Portugal

University of California, Santa Barbara, United States

Universidade Federal de Viçosa (UFV), BR

Instituto Agronômico de Campinas, IAC, Brasil.

University of Insubria, Varese, Italy

Lund University, Lund, Sweden

Inst. Geológico, Sec. do Meio Amb. do Est. de SP (IG/SMA),BR

University Jaume I- Pesticides and Water Research Institute, Spain

Debrecen University, Hungary

Instituto Nacional de Pesquisas Espaciais (INPE), BR

Universidade de São Paulo, USP, BR

Embrapa Pecuária Sudeste, CPPSE, São Carlos, SP, BR

Institute of Regional Medicine, National University of the Northeast, Corrientes, Argentina

Universidade de Taubaté, (UNITAU), BR

University of Pavia, Depart. of Civil Engineering and Architecture, Italy

LIUC - University "Cattaneo", School of Industrial Engineering, Italy

Inst. Bras. de Geogr. e Estatística (IBGE). Aracaju, SE, BR

Brno University of Technology República Tcheca

Universidade Federal da Paraíba, UFPB, BR

Univ. Est. Paulista Júlio de Mesquita Filho, UNESP, BR

Slovak Technical University in Bratislava Slovak, Eslováquia

Universidad Nacional de Córdoba, Argentina

Instituto Nacional de Pesquisas Espaciais (INPE), BR

University of Technology, China

Nelson Wellausen Dias, PPGCA, UNITAU, IBGE, BR

Theodore D`Alessio, FL, USA, Maria Cristina Bean, FL, USA

Getulio T. Batista, UNITAU, BR

Luciana Pedrosa da Fonseca Batista, - New Jersey, USA

Liliane Castro, Bibliotecária - CRB/8-6748, Taubaté, BR

Vera L. F. Batista, IPABHi \& Getulio T. Batista, UNITAU, BR

Tiago dos Santos Agostinho, LAGEO, UNITAU, BR

Luciana Gomes de Oliveira, UNITAU, BR

Library catalog entry by Liliane Castro CRB/8-6748

Revista Ambiente \& Água - An Interdisciplinary Journal of Applied Science / Instituto de Pesquisas

Ambientais em Bacias Hidrográficas. Taubaté. v. 12, n. 3 (2006) - Taubaté: IPABHi, 2017.

Quadrimestral (2006 - 2013), Trimestral (2014 - 2016), Bimestral a partir de Janeiro de 2017.

Resumo em português e inglês.

ISSN 1980-993X

1. Ciências ambientais. 2. Recursos hídricos. I. Instituto de Pesquisas Ambientais em Bacias Hidrográficas. 


\section{TABLE OF CONTENTS}

\section{COVER:}

\section{Spatial distribution of hydrological stations and watersheds studied in La Guajira Peninsula (Colombia)}

Source: DOMÍNGUEZ CALLE, E. A. et al. Objective assessment of ecosystem hydrological services in tropical areas: A Colombian experience in arid and semi-arid zones. Rev. Ambient. Água, Taubaté, vol. 12 n. 3, p. $365-$ 379, 2017. doi:10.4136/ambi-agua.2098

\section{ARTICLES \\ Hydrological modeling of the Ribeirão das Posses - An assessment based on the Agricultural Ecosystem Services (AgES) watershed model \\ 01 doi:10.4136/ambi-agua.2073 \\ Patrícia Porta Nova da Cruz; Timothy R. Green; Ricardo de Oliveira Figueiredo; Anderson Soares Pereira; Holm Kipka; Sandra Isay Saad; Jonathan Mota da Silva; Marco Antonio Ferreira Gomes \\ Objective assessment of ecosystem hydrological services in tropical areas: A Colombian experience in arid and semi-arid zones \\ 02 doi:10.4136/ambi-agua.2098 \\ Efrain Antonio Domínguez Calle; Jaime Andres Moreno Miranda; Maria Helena Olaya Rodríguez; \\ Juan Felipe Martínez; Cesar Augusto Ruíz Agudelo; Luis Francisco Madriñan; Jaime Burbano Girón; Sergio Esteban Lozano Baez}

Solid phase extraction using molecular imprinting polymers (MISPE) for the determination of estrogens in surface water by HPLC

03 doi:10.4136/ambi-agua.1991

Viviane do Nascimento Bianchi; Marcos Roberto de Araujo Silva; Marcus Augusto Lamim; Clovis Lucio da Silva; Elizabete Campos de Lima

Effects of global climate change on chlorophyll-a concentrations in a tropical aquatic system during a cyanobacterial bloom: a microcosm study

Meirielle Euripa Pádua de Moura; Lorraine dos Santos Rocha; João Carlos Nabout

Initial development of cowpea plants under salt stress and phosphate fertilization

05 doi:10.4136/ambi-agua.2070

Francisco Vanies da Silva Sá; Miguel Ferreira Neto; Yuri Bezerra de Lima; Emanoela Pereira de Paiva; Hans Raj Gheyi; Nildo da Silva Dias

Utilização da estrutura de comunidades de macroinvertebrados bentônicos como indicador de qualidade da água em rios no sul do Brasil

06 doi:10.4136/ambi-agua.2015

Flávia Bernardo Chagas; Camila Fatima Rutkoski; Gregori Betiato Bieniek; Gean Delise Leal Pasquali Vargas; Paulo Afonso Hartmann; Marilia Teresinha Hartmann

Validação de método analítico e de extração do malation em água e solo após nebulização de combate ao Aedes aegypti

07 doi:10.4136/ambi-agua.1993

Ana Carla Coleone; Flavio Soares da Silva; Angela Aparecida Machado; Joaquim Gonçalves Machado Neto; Wanderley da Silva Paganini

Caracterização de parâmetros de qualidade da água na área portuária de Barcarena, PA, Brasil

08 doi:10.4136/ambi-agua.1910

Alba Rocio Aguilar Piratoba; Hebe Morganne Campos Ribeiro; Gundisalvo Piratoba Morales;

Wanderson Gonçalves e Gonçalves 
Estudo da tratabilidade de lixiviado gerado em um aterro controlado

09 doi:10.4136/ambi-agua.1957

Daniela Vidal Vasconcelos; Larissa Loureiro Salgueiro Silva; Igor Lopes Guerra; Juacyara

Carbonelli Campos

\section{Análise bacteriológica da água de consumo comercializada por caminhões-pipa}

doi:10.4136/ambi-agua.1934

10 Maria Helena Martins Mendonça; Sthefany Angely Moraes Roseno; Thayany Ruanny Leite Cachoeira; Ákylla Fernanda Souza Silva; Paula Regina Luna de Araújo Jácome; Agenor Tavares Jácome Júnior

Análise hidrodinâmica do estuário do rio Lima, Portugal, a partir de simulação numérica

11 doi:10.4136/ambi-agua.1925

Nelson Carvalho Dantas de Brito Costa; Stênio de Sousa Venâncio; José Luís da Silva Pinho; José Manuel Pereira Vieira

Variabilidade de concentração de metano na região do Pantanal Mato-grossense usando dados do satélite AQUA

12 doi:10.4136/ambi-agua.1985

Tonny Jader de Moraes; Fernando da Silva Sallo; Carlo Ralph de Musis; Luciana Sanches; Iramaia Jorge Cabral de Paulo; Rafael da Silva Palácios

Efetividade do ensaio Trad-MCN para avaliação de contaminantes atmosféricos em regiões brasileiras

Juliana Caroline Vivian Sposito; Luiza Flávia Veiga Francisco; Alexeia Barufatti Grisolia 


\begin{tabular}{|c} 
Ambiente \& Água - An Interdisciplinary Journal of Applied Science \\
ISSN 1980-993X - doi:10.4136/1980-993X \\
www.ambi-agua.net \\
E-mail: ambi.agua@gmail.com
\end{tabular}

\title{
Hydrological modeling of the Ribeirão das Posses - An assessment based on the Agricultural Ecosystem Services (AgES) watershed model
}

\author{
doi:10.4136/ambi-agua.2073
}

Received: 30 Dec. 2016; Accepted: 12 Apr. 2017

\author{
Patrícia Porta Nova da Cruz ${ }^{*}$; Timothy R. Green²; \\ Ricardo de Oliveira Figueiredo ${ }^{1}$; Anderson Soares Pereira ${ }^{1}$; \\ Holm Kipka ${ }^{3}$; Sandra Isay Saad ${ }^{4}$; Jonathan Mota da Silva ${ }^{5}$; \\ Marco Antonio Ferreira Gomes ${ }^{1}$

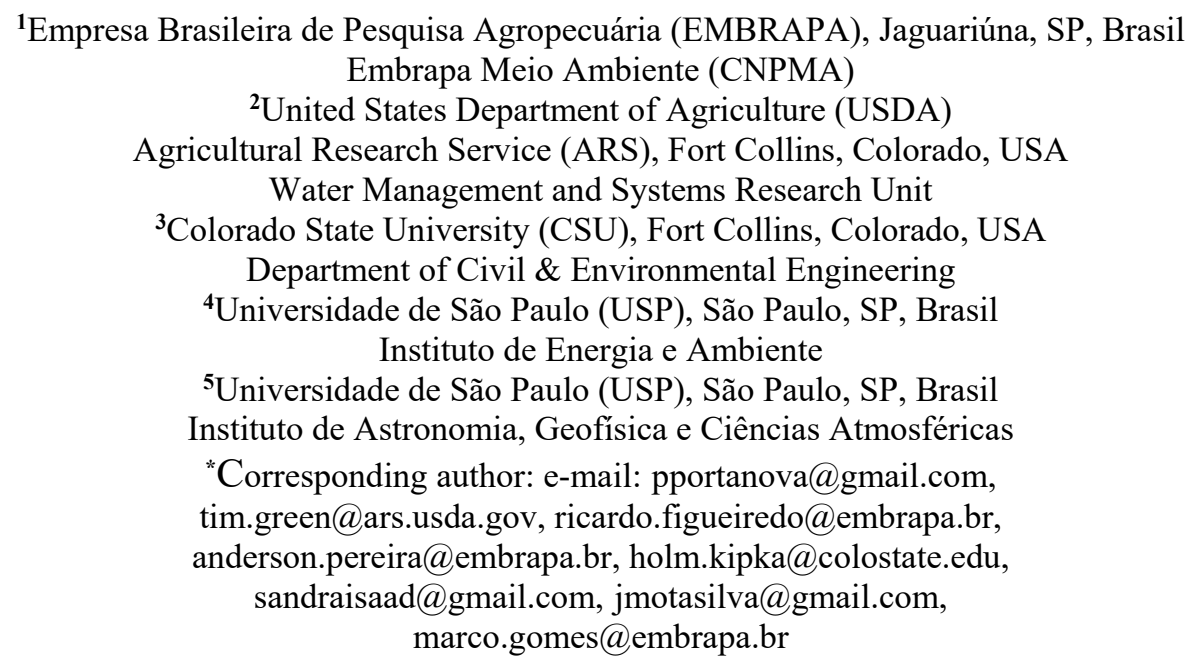

\begin{abstract}
Southeastern Brazil has recently experienced drought conditions that have impacted watershed conservation and the management of water quality and quantity for agricultural and urban demands. The Ribeirão das Posses watershed is being monitored as a headwater of the Jaguarí River, which is one of the contributing rivers of the Cantareira Reservoir Complex in the state of São Paulo. The landscape has changed over the last century from native forests to more homogeneous vegetation for pastures, crops and some forest plantations of eucalyptus, which have cumulative impacts on water yield and quality. Currently, the Projeto Conservador das Águas (Water Conservationist Project) has planted small areas with native species vegetation in order to recover degraded areas. The objective of this study was to evaluate the quantity of water in the Ribeirão das Posses Basin by both measurements and by simulating hydrological responses. The Agricultural Ecosystem Services (AgES) watershed model was applied to simulate water movement and storage among land areas. The simulation period was from 2009 to 2014, because the daily streamflow and meteorological data were available for model calibration and testing. We discuss data input requirements, model calibration to fit measured streamflow, and sensitivity to spatially variable rainfall inputs. The calibrated model may be used to estimate streamflow during periods of missing data, and in the future to estimate
\end{abstract}


impacts of land use changes on stream water quantity and quality. Such information can be used in programs of payments for ecosystem services.

Keywords: climate, ecosystem services, hydrology, water conservation, watershed model.

\section{Modelagem hidrológica do Ribeirão das Posses - Uma avaliação baseada no modelo Serviços Agrícolas Ecossistêmicos (AgES) da bacia}

\section{RESUMO}

A recente estiagem no Sudeste do Brasil tem impactado a conservação de bacias hidrográficas e a gestão da qualidade e quantidade da água para as demandas agrícolas e urbanas. A Bacia do Ribeirão das Posses está sendo monitorada por ser uma bacia de cabeceira da Bacia do Rio Jaguari, importante contribuinte do Sistema Cantareira no estado de São Paulo. A paisagem foi alterada no século passado, a partir de florestas nativas para uma vegetação mais homogênea como pastos, campos agrícolas e florestas de eucalipto, que geram impactos cumulativos sobre a quantidade e qualidade da água. Atualmente, o Projeto Conservador das Águas tem restaurado pequenas áreas com vegetação nativa para a recuperação de áreas degradadas. O objetivo dessa pesquisa foi avaliar a quantidade da água na Bacia do Ribeirão das Posses usando dados observados e dados da simulação de respostas hidrológicas. O modelo de bacia "Serviço Agroecossistêmico" (AgES) é aplicado para simular a variação no armazenamento e movimento da água nas áreas terrestres. O período de simulação (2009-2014) foi definido em função da disponibilidade dos dados de vazão e meteorológicos para calibrar e testar o modelo. Dados de entrada requisitados, calibração do modelo para ajuste à vazão medida e a sensibilidade do modelo aos dados de chuva são discutidos neste artigo. O modelo calibrado pode ser utilizado para estimar vazões durante períodos com dados ausentes e, no futuro, para analisar os impactos de mudança de uso da terra sobre a quantidade e qualidade da água. Essas informações podem ser usadas em programas de pagamentos por serviços ambientais.

Palavras-chave: clima, conservação da água, hidrologia, modelo de bacia hidrográfica, serviços ecossistêmicos.

\section{INTRODUCTION}

In 2014, Southeastern Brazil experienced a severe drought which has impacted the water quality and quantity for various demands. Increasing concerns exist about the watersheds of the Piracicaba, Capivari and Jundiaí Rivers, that cover an area of $15,303 \mathrm{~km}^{2}$ in the states of São Paulo (92.6\% of the area) and Minas Gerais (7.4\% of the area), and form a management region "PCJ Basins" (Bacias PCJ). In the 1990's, PCJ committees were created by federal and state legislation to direct the management of the PCJ Basins.

The PCJ Basins have five million inhabitants and the second largest industrial region in Brazil. Moreover, water from part of the PCJ Basins feeds into the Cantareira reservoir system that supplies more than eight million inhabitants in the São Paulo metropolitan area at an average rate of $31 \mathrm{~m}^{3} \mathrm{~s}^{-1}$, or approximately 2.7 million $\mathrm{m}^{3} \mathrm{~d}^{-1}$. In this context, some of the most important parts of the PCJ Basins are the headwater areas in Minas Gerais state, whose catchments feed the Jaguari River, a tributary of the Piracicaba River and a fundamental source of inter-basin transfers through the Cantareira reservoir system. 
The entire Jaguari watershed covers an area of $4,320 \mathrm{~km}^{2}$, including the vital headwater areas mentioned before. Originally covered by dense vegetation of the Atlantic Forest biome (Mata Atlântica), these headwater areas were converted to primarily agricultural lands, with beef and mostly dairy production serving as the primary source of revenue for farmers. Productivity is relatively low, as most farms are small, grazing potential is limited, and the labor force is aging (Gavaldão, 2009).

Inadequate agricultural management is an important factor contributing to deteriorating water production and quality (Solbé, 1986). According to DeFries and Eshleman (2004), land-use change will have a large impact on the water resources in the near future. Deforestation removes protective vegetation layers, and usually contributes to decreased evapotranspiration, and increased surface water runoff and erosion. As a potential consequence, flooding may occur and transport sediments into rivers, lakes and reservoirs. As rich surface soil layers are lost, reforestation of such areas is difficult, and parts of the landscape has become inhospitable for many native species (Ward and Trimble, 2011).

Moreover, climate change is likely to impact water resources in the basins, as it may be significant in the regional scale (Marengo et al., 2009). Consequently, it is necessary to understand the biophysical processes related to the water cycle and associated ecosystem services related to the water quality and quantity.

In 2005, the municipality of Extrema established laws to help enforce public policies regarding water resource management. To facilitate this, Projeto Conservador das Águas was created, with the support of ANA (Brazilian National Water Agency), stimulating payments for environmental services (PES). The Projeto Conservador das Águas assists farmers that participate in this project to adopt soil conservation practices, apply rural sewage systems, and restore riparian zones, steep slopes and hilltops lands of the Serra da Mantiqueira. Projeto Conservador das Águas has planted native species within three selected catchments, especially in riparian zones, around springs, and at hilltop positions, in order to restore forest vegetation. One of these catchments is the $12 \mathrm{~km}^{2}$ Ribeirão das Posses watershed, where the landscape has changed over the last two centuries from native forests to mostly pastures, and small areas of crops and some forest plantations of eucalyptus.

In this context, agro-hydrological modeling tools can generate information about water responses to climate and land use changes, to guide long-term planning for these watersheds which is essential for water resource management and sustainability (Targa and Batista, 2015). The Agricultural Ecosystems Services (AgES) watershed model (formerly called AgES-W) is used to simulate spatially variable water movement and storage among land areas or hydrological responses units. The objectives are to evaluate the water flow in the Ribeirão das Posses using measured data and simulation with the AgES model. We simulated the years 2009 to 2014 using available streamflow and rainfall data. We expect to provide scientific tools to help to analyze public policies of payments for ecosystem services (PES) by using calibrated models such as AgES to assess the effects of land-use change on the water resources quality and quantity, and simulate the combined effects of the projected climate changes.

\section{MATERIALS AND METHODS}

\subsection{Study Area}

The Ribeirão das Posses watershed is located in the south of Minas Gerais State, Brazil, and extends between geographic coordinates from $22^{\circ} 49^{\prime} 46^{\prime \prime}$ to $22^{\circ} 53$ ' $21^{\prime \prime}$ south and from $46^{\circ} 13^{\prime} 24^{\prime \prime}$ to $46^{\circ} 15^{\prime} 08^{\prime}$ " west (Figure 1). With an area of $12 \mathrm{~km}^{2}$, this headwater catchment of the Jaguari River is one of the contributing rivers of the Cantareira Reservoir Complex in the state of São Paulo and will likely become a long-term monitoring site. 


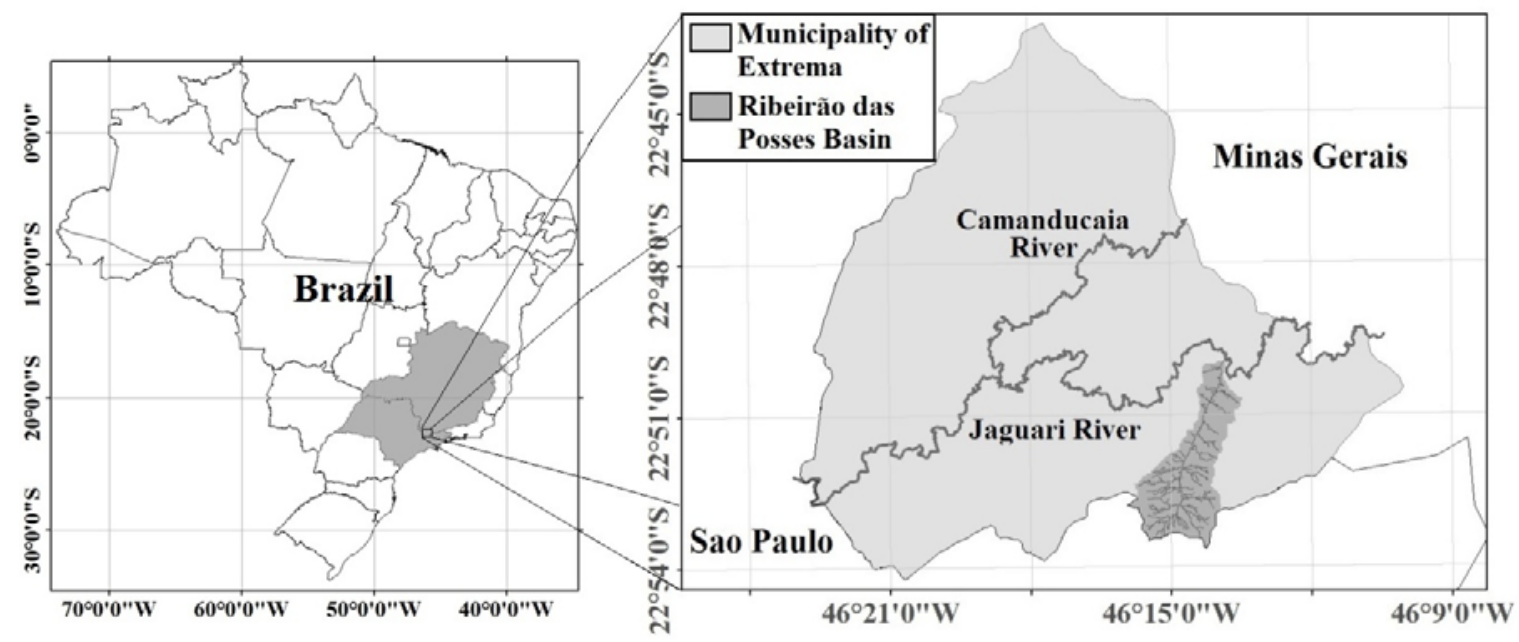

Figure 1. Map of the study location within the States of Minas Gerais and São Paulo, Brazil.

Ribeirão das Posses has elevations ranging from 1,144 to 1,739 m (Lima, 2013), including steep slopes in the upper portions. The climate in the sub-basin is defined as a hot and humid summer and with dry winter ( $\mathrm{Cwb}$ climate class in Köppen). The average temperatures during the winter and the summer are $13.1^{\circ} \mathrm{C}$ and $25.6^{\circ} \mathrm{C}$, respectively, with annual occurrences of frosts. The mean annual rainfall is $1,477 \mathrm{~mm}$ (ANA, 2008). The Posses sub-basin has over one hundred rural properties sustaining subsistence farming (Zolin et al., 2014).

\subsection{Agricultural Ecosystems Services (AgES) Watershed Model}

AgES is a modular, Java-based model developed and implemented under the Object Modeling System (OMS) (David et al., 2013). AgES is a spatially distributed watershed model (Ascough et al., 2015a) with the main components taken primarily from the J2000 (Krause et al., 2006) and J2000-SN models (Fink et al., 2007) and has been applied to cropping systems in Colorado (Green et al., 2015) and the Midwest USA (Ascough et al., 2015a). The AgES model explicitly simulates the hydrologic and agronomic responses from spatially distributed land use, management, and weather conditions across inter-connected land units.

One specific function of the AgES model is the simulation of the interactions, both hydrological and chemical, between land areas, using the concept at Hydrological Response Units (HRUs), and the calculation of the overland and subsurface lateral flows. For a single HRU, AgES simulates the fluxes of infiltration, runoff and vertical redistribution of soil water at a daily time step (Green et al., 2015). This approach provides biophysical process-based and detailed calculation of the water balance and nutrients within each HRU. Figure 2 shows the conceptual hydrologic and nitrogen components of AgES linked to the land use management and crop growth components.

\subsection{Data input and processing}

The AgES model requires various spatial and temporal inputs, which define the model structure (spatial extents and topology), parameters (e.g., soil and plant properties) and weather time series (daily basis). For this study, a soil class map (15x15 m ground resolution) was used, adapted from Lima (2013). The land use map (2.5x2.5 m ground resolution) and Digital Elevation Model (DEM) with $5 \mathrm{~m}$ grid spacing were obtained from the Secretary of Environment of Extrema. Figure 3A-C shows the DEM, soil class and land use maps. Daily meteorological data (solar radiation, minimum and maximum air temperatures, wind speed, rainfall and air relative humidity) drive the model. The model simulates the streamflow at the 
outlet, runoff at different land areas, and water quality within the basin. Here, we focus on spatial and temporal model inputs.

The HRUs (Figure 3D) were delineated using WDAML (Watershed Delineation in ARC Macro Language) software. This program is an AML tool based on multiple flow direction topology and input layers for soils and land use (Pfennig et al., 2009; Green et al., 2014). We used the DEM and soil class map to make the HRUs.

The climate data were obtained from the National Centers for Environmental Prediction (NCEP) Climate Forecast System Reanalysis (CFSR) site: globalweather.tamu.edu (see also Fuka et al., 2013) and rainfall measurements from field gauges obtained from the Agência Nacional de Águas (ANA, National Water Agency: hidroweb.ana.gov.br). We interpolated multiple spatial points to produce daily weather variables for each HRU; see details in the results.

Daily stream flow data were obtained from ANA and checked for consistency and data quality. Only station S2 (Figure 3D) was used in this study.

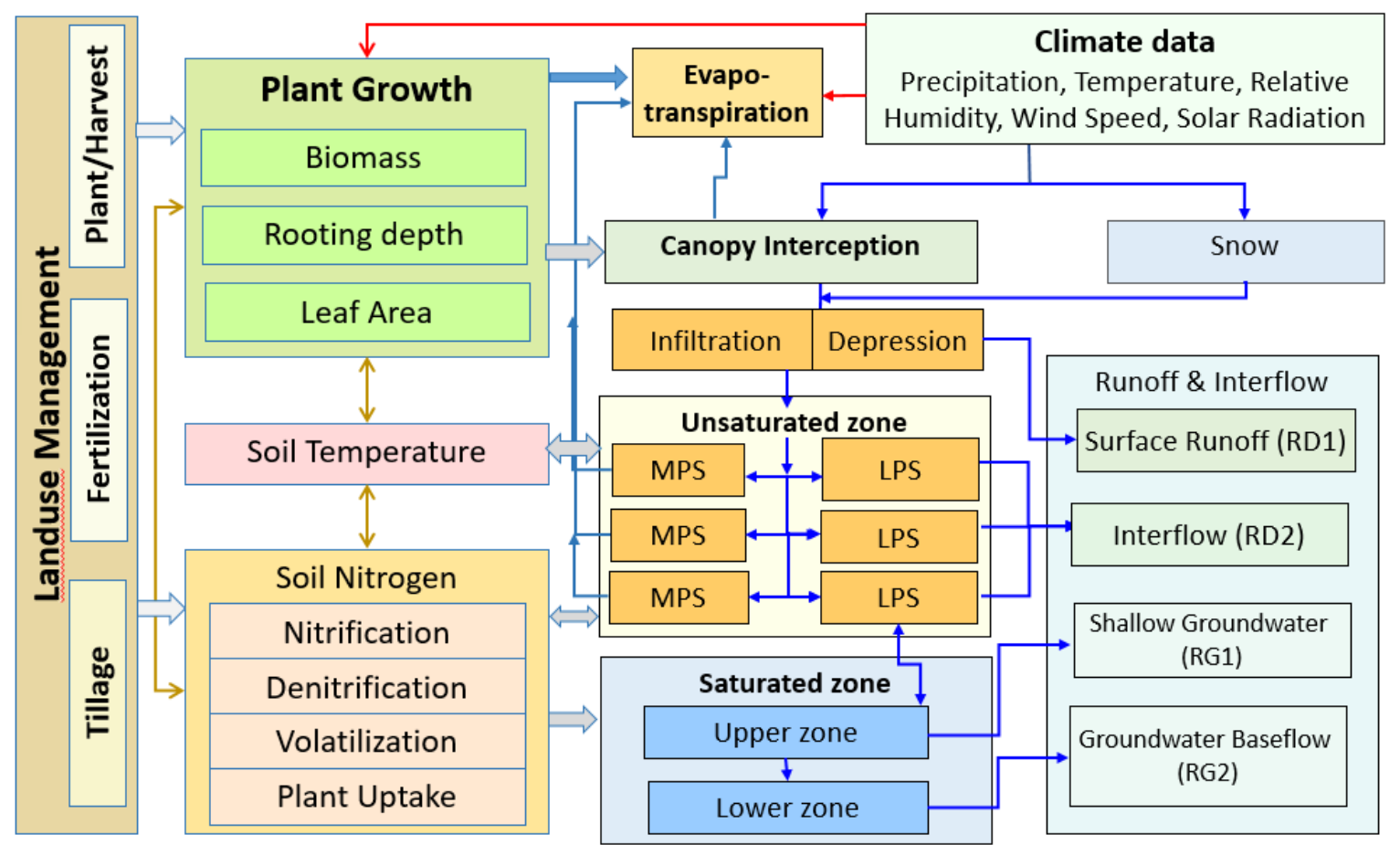

Figure 2. Conceptual hydrologic and nitrogen $(\mathrm{N})$ components of AgES coupled with land use management and crop growth components (Adapted from Ascough et al., 2015b). MPS is medium pore storage, and LPS is large pore storage.

\subsection{Model calibration}

The AgES model was calibrated to simulate the streamflow compared to measurements at the outlet of Ribeirão das Posses watershed. Daily streamflow data were used to calibrate the model using a Shuffled Complex Evolution method called Luca (Hay and Umemoto, 2006; Green et al., 2015) in OMS. The objective function used in Luca was the Root Mean Squared Error (RMSE) between measured and simulated daily streamflow. Measurements of precipitation using all five rain gauges (R1-R5 in Figure 3D) were used as input in the model calibration. The calibration scheme is defined in Table 1, where parameters are grouped by processes into steps. The parameter values are "shuffled" within each step, and the model is executed iteratively until convergence before proceeding to the next step. After five steps, Luca repeats these steps for a specified number of rounds. 

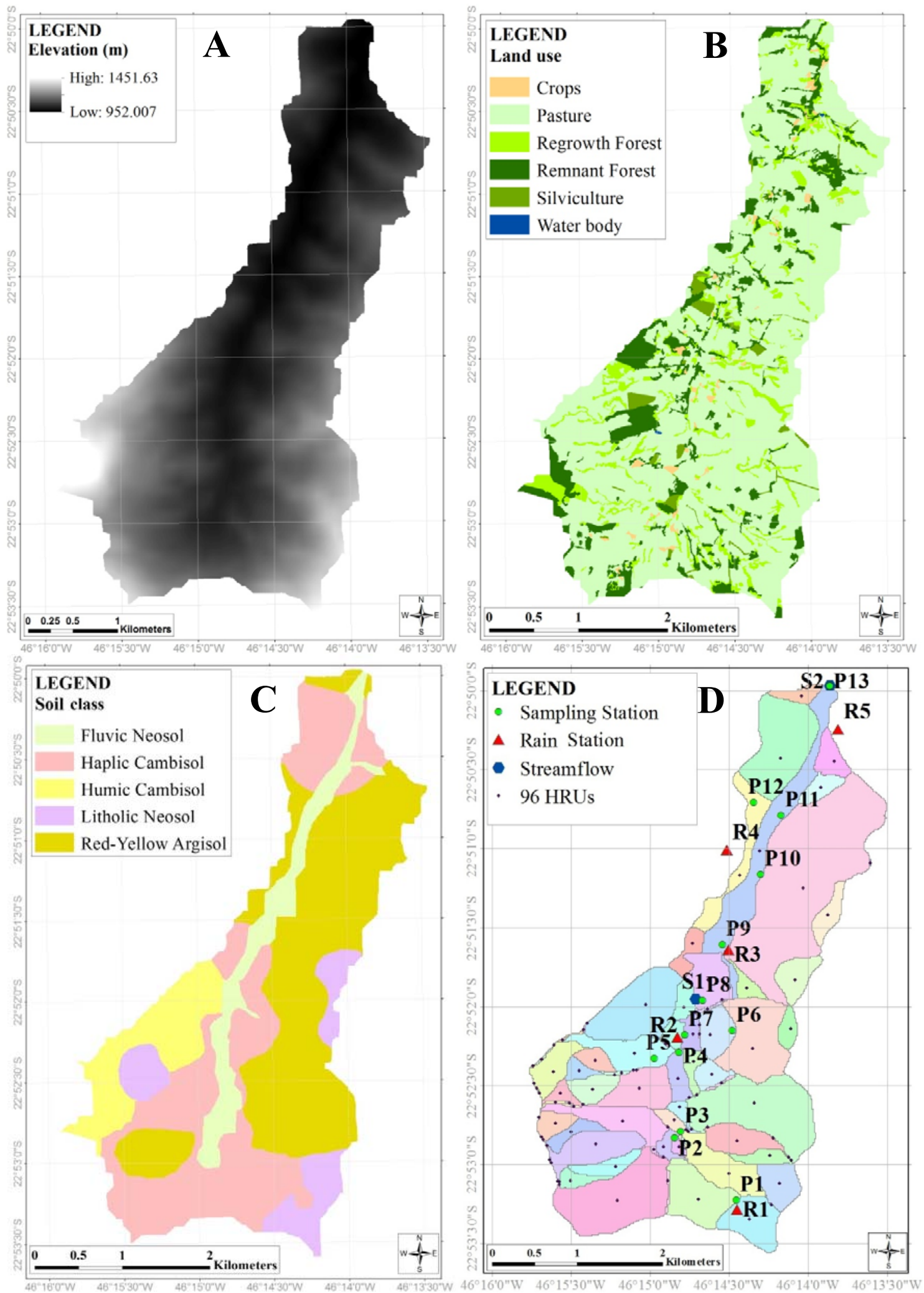

Figure 3. Maps of the study location: (A) watershed delineation and topography based on a 5-m Digital Elevation Model (DEM); (B) land use classes; (C) soil class (Adapted from Lima, 2013); and (D) Hydrological Response Units (HRUs). Labelled points show gauging stations for: streamflow (S) and rainfall (R) of ANA and the Geological Survey of Brazil (CPRM), and water quality collected by Embrapa and CENA/USP (P). 
Table 1. AgES model parameters used in the sensitivity analyses and calibration. Parameters are grouped into five steps for calibration in Luca. All parameters were assumed to be spatially uniform, but model responses can vary spatially by HRU. Details of the parameter definitions and process controls (response functions) are given in Green et al. (2015).

\begin{tabular}{lcll}
\hline Parameter Name & $\begin{array}{c}\text { Calibrated } \\
\text { Value }\end{array}$ & Units & \multicolumn{1}{c}{ Description } \\
\hline BetaW & & & Step 1 \\
soilPolRed & 5.997 & --- & shape factor for relative transpiration, T/PET \\
\hline & 83.979 & --- & Polynomial ET reduction factor \\
\hline flowRouteTA & 1.001 & --- & Step 2 \\
soilMaxDPS & 49.998 & $\mathrm{~mm}$ & maximum depression storage \\
soilMaxInfSummer & 47.273 & $\mathrm{~mm} \mathrm{~d}^{-1}$ & Infiltrability parameter for southern hemisphere "summer" \\
soilMaxInfWinter & 62.054 & $\mathrm{~mm} \mathrm{~d}^{-1}$ & Infiltrability parameter for southern hemisphere "winter" \\
soilDistMPSLPS & 0.158 & --- & controls distribution of infiltration to MPS and LPS \\
\hline & & & Step 3 \\
\hline soilDiffMPSLPS & 6.898 & --- & controls flux of water from LPS to MPS \\
soilOutLPS & 6.002 & --- & exponent in equation for LPS outflow \\
kdiff_layer & 0.227 & --- & resistance parameter for capillary flow between layers \\
soilLatVertLPS & 0.500 & --- & lateral/vertical distribution coefficient for LPS \\
\hline & & & Step 4 \\
\hline kf & 125.104 & $\mathrm{~cm} \mathrm{~d}^{-1}$ & saturated hydraulic conductivity \\
aircapacity & 0.650 & $\mathrm{~m}^{3} \mathrm{~m}^{-3}$ & soil porosity or saturated water content \\
fieldCapacity & 0.257 & $\mathrm{~m}^{3} \mathrm{~m}^{-3}$ & one-third bar soil water content (separates MPS and LPS) \\
deadCapacity & 0.0002 & $\mathrm{~m}^{3} \mathrm{~m}^{-3}$ & residual soil water content \\
\hline & & & Step 5 \\
\hline initRG1 & 0.266 & --- & initial storage of RG1 relative to maximum storage \\
gwRG1RG2dist & 2.989 & --- & RG1/RG2 distribution coefficient \\
gwRG1Fact & 0.574 & --- & adaptation of RG1 outflow \\
gwRG2Fact & 10.314 & --- & adaptation of RG2 outflow \\
\hline & & &
\end{tabular}

The calibration of AgES with Luca at this small watershed scale with 96 HRUs (Figure 3D) used thousands of iterations over approximately three days on a personal computer to complete three "rounds" with five "steps" each. Convergence to a globally optimal parameter set is indicated when the parameter values stabilize from one round to another. This method thus accounts for parameter interactions within and among steps, if they exist.

\section{RESULTS AND DISCUSSION}

For data processing (2.3), we faced some challenges and overcame them as follows:

- Short time series of meteorological and hydrometric data - Only nine years with rain data. Lack of field measurements of air humidity, wind speed, air temperature and solar radiation. Without these data, the model interpolates data using only two points in the vicinity with available data. The weather data (CFSR) was available until July 2014. 
- Missing data - The rainfall time series have a few missing values, some gauges are missing 30 days over the full period, and one station (R5) is missing four months of data (5.6\% in Table 2). The stream discharge data have more gaps. Although this can be problematic in general, the calibration routine ignores missing data and uses only the available data. For weather data, each day must have at least one valid value (one station) for each meteorological variable. If more than one station has data, values are interpolated spatially.

- Data quality assessment - The raw rainfall data quality was generally good, but the raw discharge data showed inconsistencies and many gaps. We used a database gap-filled by Silva (2014) and Saad (2016), who checked the data quality and made adjustments as needed. Deviations of the model calculations from "observed" streamflow can be caused by either model structural errors (inability to simulate real-world biophysical responses), calibration errors and inability to identify optimal parameter sets with limited information content using streamflow only at the outlet, or measurement errors and related data quality issues, and combinations of these factors.

- Mapping land use and agricultural management practices spatially and temporally - We used a $2.5 \mathrm{~m}$ resolution spatial land use map derived from WorldView (2 Satellite Images with resolution of $60 \mathrm{~cm}$ ) available for two years, 2004 and 2009, but only the latter has been used since it is the most recent. It is not strictly representative of a long period, because land use and agricultural management may likely have changed. Based upon the land use map, approximately $70 \%$ of land area is pasture. With this information, we decided to consider the whole basin as pasture for this study as a first approximation. Simulation of forests and crops is possible with AgES, but the current approach avoided the need for a long "warm-up" period in which trees would grow to maturity.

Despite these limitations and challenges, collaboration with national and local agencies provided the necessary input data to run AgES for a period of six years (2009-2014). Table 2 shows the periods of rainfall data availability. Since the AgES model interpolates rainfall for each day using only the available stations on that day, it is possible to have missing data or different periods of data.

Annual rainfall for each rain gauge from October 2008 to September 2014 is presented in Figure 4 (Water Year is October 1 to September 30 in this region), which displays a slight orographic effect with a tendency for rainfall to increase with elevation. Also, inter-annual variability is more pronounced than spatial variability within the Posses watershed, and drought conditions are evident in Water Years 2013-2014.

Table 2. Rainfall Stations and periods of available data.

\begin{tabular}{lcccc}
\hline Station ID & Station Code & Elevation $(\mathrm{m})$ & $\begin{array}{c}\text { Data Period } \\
\text { (month/year) }\end{array}$ & $\begin{array}{c}\text { Percentage of Days } \\
\text { with missing data (\%) }\end{array}$ \\
\hline R1 & 2246167 & 1,197 & $11 / 2008-05 / 2016$ & 2.2 \\
R2 & 2246168 & 1,003 & $11 / 2008-05 / 2016$ & 1.6 \\
R3 & 2246169 & 973 & $11 / 2008-05 / 2016$ & 2.3 \\
R4 & 2246170 & 966 & $11 / 2008-05 / 2016$ & 1.1 \\
R5 & 2246171 & 965 & $11 / 2008-05 / 2016$ & 5.6 \\
\hline
\end{tabular}

Rev. Ambient. Água vol. 12 n. 3 Taubaté - May / Jun. 2017 


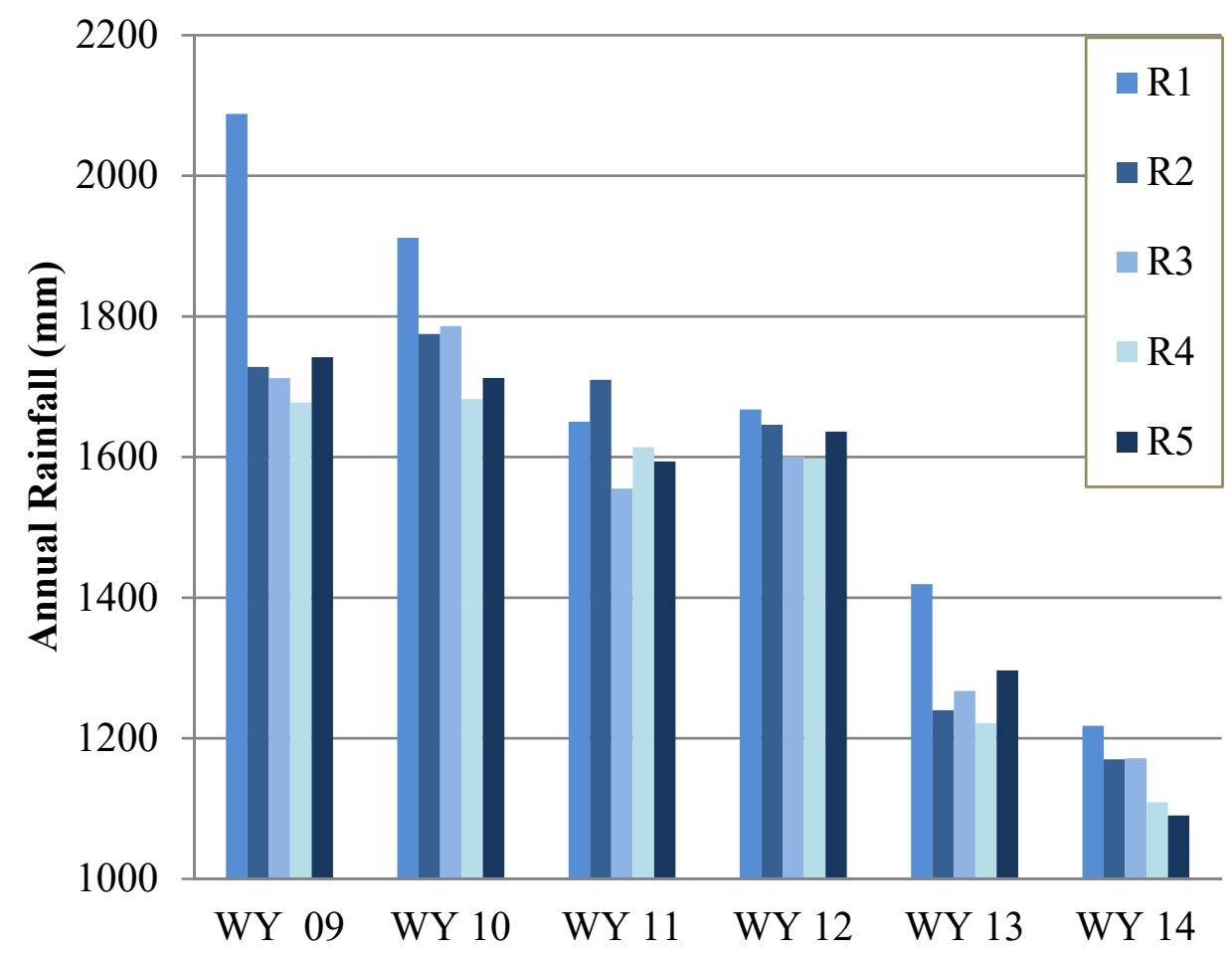

Figure 4. Annual rainfall amounts recorded at five rain gauges (R1-R5 in Figure 3D) used for inputs to AgES. WY denotes Water Year (previous calendar year Oct. 1 - Sep. 30). Note: The graph starts at $1000 \mathrm{~mm}$, which amplifies the differences.

The temporal streamflow pattern follows the seasonal precipitation pattern (Figure 5A). Typically, the streamflow response is almost immediate within the day of precipitation, since the basin is relatively small and wet with a short dry season. This is seen as spikes in both measured and simulated streamflow (Figure 5B). The results also reflect historical drought conditions during 2013 to 2014 in the study area. However, AgES could not reproduce all of the daily flows, and some events were similar in magnitude but the timing was off. The largest differences between the simulated and observed discharge were seen in peak events. This was the main reason for a high value for the Root Mean Square Error (RMSE), $0.257 \mathrm{~m}^{3} \mathrm{~s}^{-1}$, for a microbasin like Ribeirão das Posses. The SWAT model has the same difficulty of simulating the daily flow during peak flow events, having underestimated the flow (Silva, 2014). To discuss these differences more precisely, we show the differences between simulated and measured streamflow in Figure 5C. The main series of negative differences (simulated $<$ observed) occurred in 2012-2014, when the precipitation increased slightly but this response did not occur in the simulated flow. This could be because the region went through a dry period and, when it started to rain a bit more, there was more available storage in the soils and an increase in infiltration; likewise, groundwater levels were lower and baseflow decreased. Thus, the rain patterns are similar to flow except during the dry season.

After calibrating AgES using all five gauges (R1-R5) as the base case, we simulated streamflow with different rain gauges as inputs using the same set of calibrated model parameters (Table 1). For this analysis only R1 or R3 or R5 were used to test the model sensitivity to rainfall inputs (Figure 6A). The annual streamflow amount is not too sensitive, but some peak flows deviated substantially. The differences (Figure 6B) exceeded the deviations of simulated verses measured values on some dates. We note that R3 in the middle 
of the watershed (Figure 3D) produced the largest deviation in Jan 2011, and R1 can give the opposite deviations (see Water Year 2010 in Figure 6B). The differences shown for a specific rain gauge simulation are due to the bias in the rainfall time series. Thus, spatial differences in measured rainfall data can have substantial effects on the simulated runoff using a spatial watershed model like AgES. It is also worth noting that most watersheds of this size will not have more than one rain gauge, so such differences would be unknown.
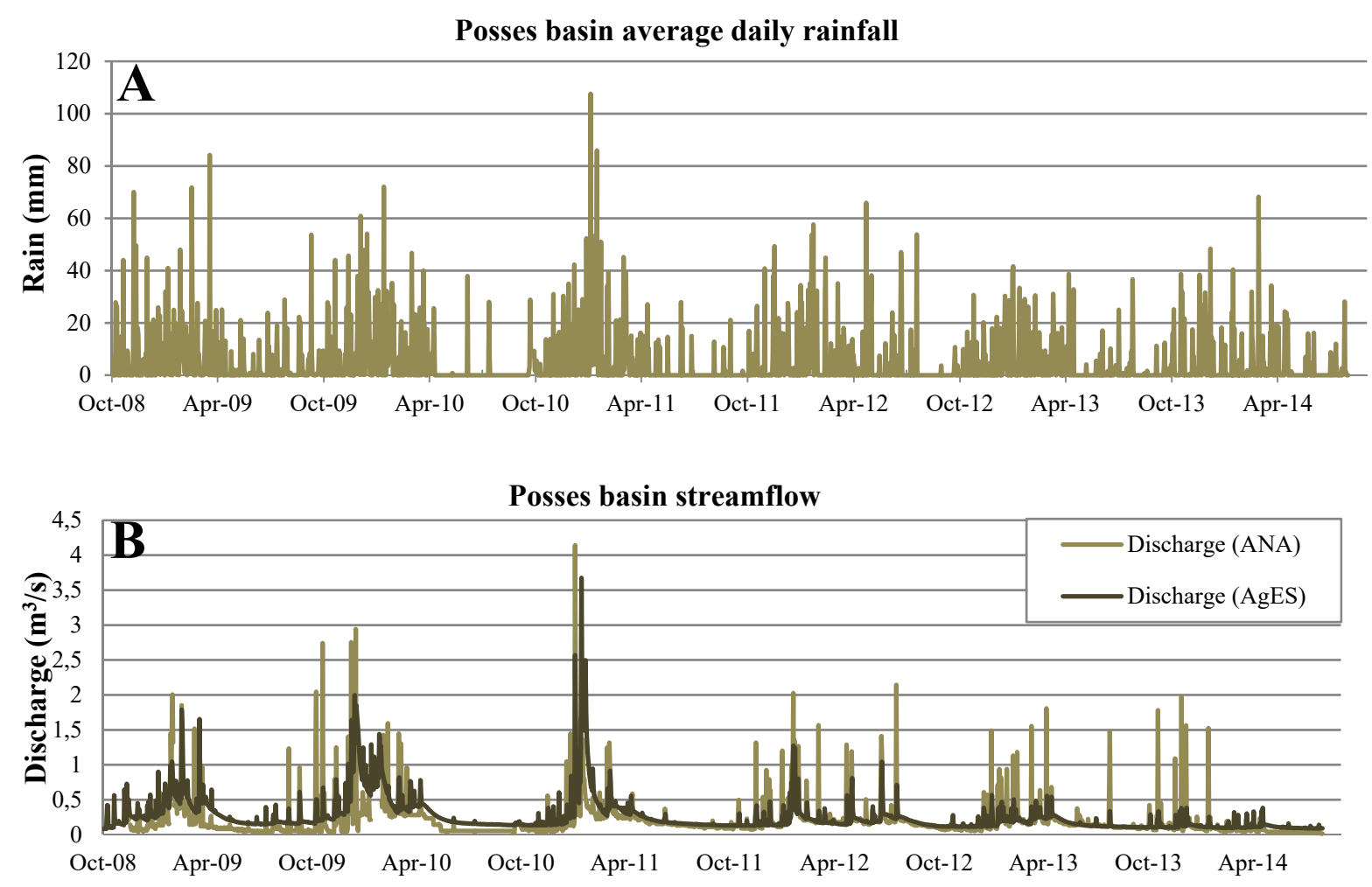

Difference (simulated - measured)

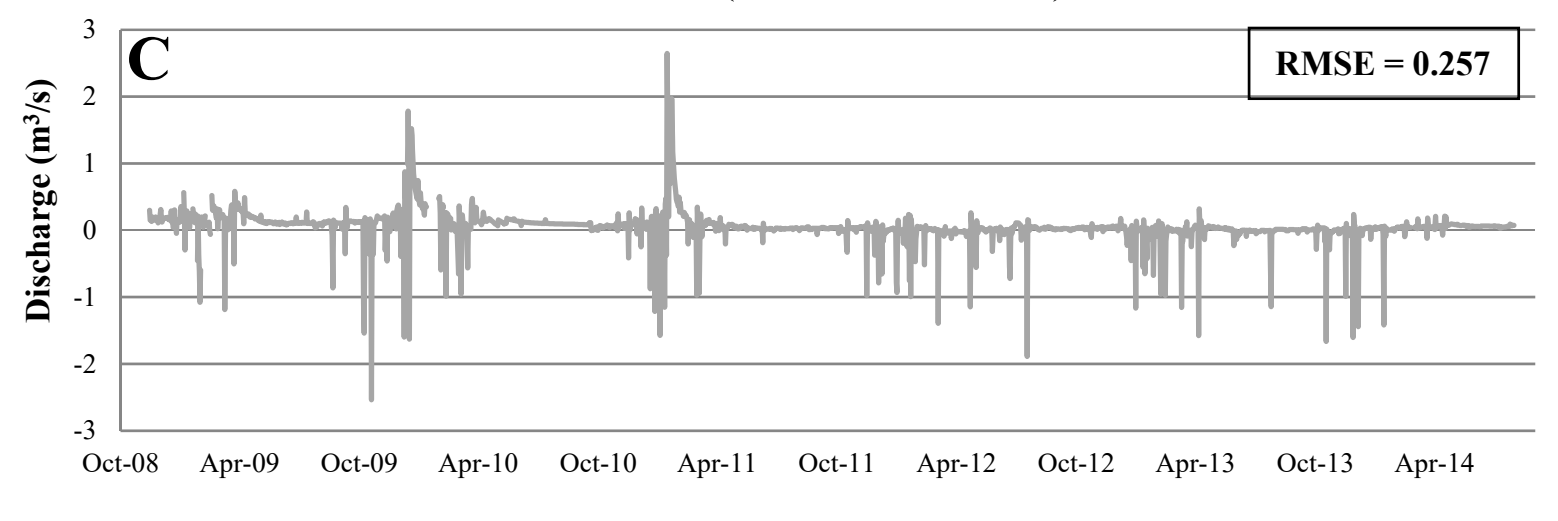

WATER YEAR 2009 |WATER YEAR 2010 |WATER YEAR 2011 |WATER YEAR 2012 |WATER YEAR 2013 |WATER YEAR 2014

Figure 5. Daily values of (A) basin-average rainfall estimated by AgES from rain gauges, (B) stream discharge at the outlet measured and simulated, and (C) difference between simulated minus observed stream discharge at the outlet. 

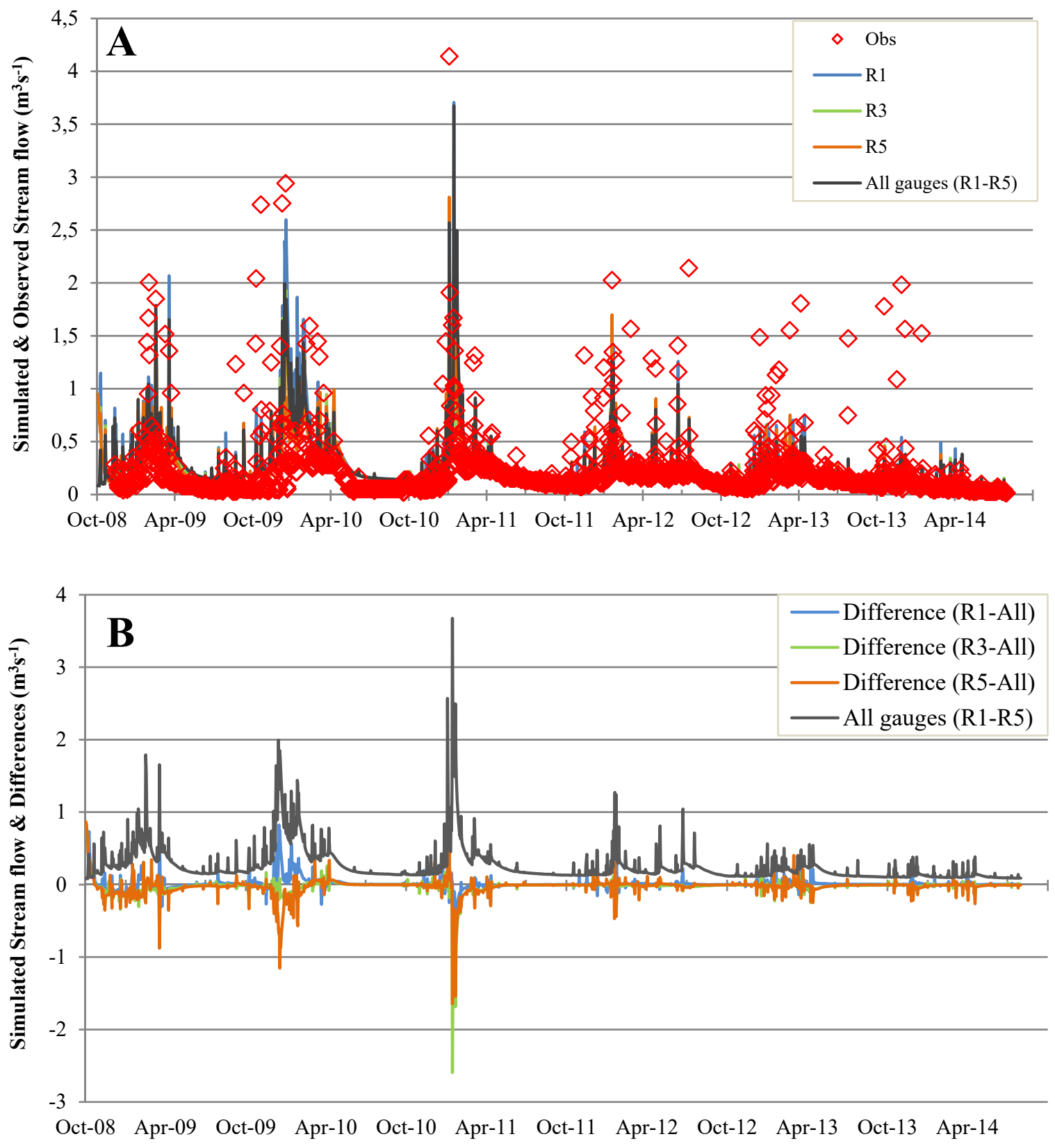

WATER YEAR 2009 |WATER YEAR 2010 |WATER YEAR 2011 |WATER YEAR 2012 |WATER YEAR 2013 |WATER YEAR 2014 |

Figure 6. (A) Simulated and observed streamflow with different rain gauges inputs, and (B) simulated streamflow and differences.

\section{CONCLUSIONS}

The AgES watershed model performed relatively well for simulating stream flow at the outlet of the Ribeirão das Posses basin, and we conclude that AgES can be used for evaluating the particular hydrological responses. The results reflect historical drought conditions during 2013 to 2014 and the streamflow response is almost immediate within the day of precipitation, since the basin is relatively small and wet with a short dry season. However, the RMSE was high due the high difference between the values simulated and observed in peak flows. AgES could not reproduce all of the daily flows, and some events were similar in magnitude but the timing was off. We should also remember that these results assumed that pasture (grass) 
covered the entire watershed. AgES should perform even better when using a more realistic distribution of land use based on maps with historical information.

Quantitative assessments of potential benefits of conservation practices in southeastern Brazil require both environmental field monitoring and computer simulations, such as those we discuss here. This paper illustrated the data requirements and model complexity needed to evaluate the water flow regime in areas with restoration and activities of payments for ecosystem services. The AgES model and current field data were proposed here as spatially distributed watershed tools for calibration and simulation of the water dynamics under climate variability.

The AgES model can also be used to predict watershed responses to different expected land-use patterns, and projected climate scenarios. In addition to streamflow, we plan to simulate water quality in the Ribeirão das Posses watershed. This may require further calibration and testing of the AgES model under historical (measured) conditions. Subsequently, the model may also be used to estimate missing or poor stream data.

\section{ACKNOWLEDGMENTS}

We thank Elias Gomes de Almeida, José Tadeu de Oliveira Lana and Ricardo Antonio Almeida Pazianotto, analysts at Embrapa Environment, who assisted with the generation of maps and the computational part of running the AgES model. AgES team members at USDA-ARS and Colorado State University (Jim Ascough, Nathan Lighthart, Rob Erskine, Greg McMaster, Debbie Edmunds, and Olaf David) supported the code development and deployment. $\mathrm{CNPq}$ funded this research and international collaboration under the program "Ciência Sem Fronteiras" (Science without Borders Program) (Grants 401178/2014-5, 150143/2015-3 and 150043/2016-3). Drs. Humberto Ribeiro da Rocha and Mark Tomer provided helpful comments prior to journal submission. We also thank EMBRAPA (SEG021421002) and FAPEMIG (APQ-03157-13) for supporting this work under the scope of the research project "Land use effects on quali-quantitative aspects of water resources in headwater areas of the Camanducaia and Jaguari river basins" with the partnership of the AgroHidro Network as well as the collaborative work with the FAPESP Project number 2016/02890-1 (Impact of Climate Change on the hidrobiogeochemistry of two small tributary watersheds to Cantareira system in an area attended by a program of Payment for Environmental Services).

\section{REFERENCES}

AGÊNCIA NACIONAL DE ÁGUAS - ANA (Brasil). Programa produtor de água superintendência de usos múltiplos. Brasília: Ministério do Meio Ambiente, 2008.

ASCOUGH, J. C.; GREEN, T. R.; DAVID, O.; KIPKA, H.; MACMASTER, G. S. The spatially-distributed AgroEcoSystem-Watershed (AgES-W) hydrologic/water quality (H/WQ) model for assessment of conservation effects. In: ANNUAL HYDROLOGY DAYS CONFERENCE PROCEEDINGS, 23-25 March 2015, Fort Collins, Colorado. Proceedings... Fort Collins: [s.n.], 2015a. 16p. http://hydrologydays.colostate.edu/ Papers_15/AgES-W_paper.pdf

ASCOUGH, J. C.; GREEN, T. R.; DAVID, O.; KIPKA, H.; MACMASTER G. S.; LIGHHART, N. P. The AgroEcoSystem-Watershed (AgES-W) model: Overview and application to experimental watersheds. AMERICAN SOCIETY OF AGRICULTURAL AND BIOLOGICAL ENGINEERS, 2015, New Orleans. Proceedings... New Orleans: ASABE, 2015b. p. 339-349. http://doi.org/10.1016/j.agwat.2014.02.006 
DAVID, O.; ASCOUGH, J. C.; LLOYD, W.; GREEN, T. R.; ROJAS, K. W.; LEAVESLEY, G. H. et al. A software engineering perspective on environmental modeling framework design: The Object Modeling System. Environmental Modelling \& Software, v. 39, p. 201-213, $2013 \mathrm{http}: / /$ doi.org/10.1016/j.envsoft.2012.03.006

DEFRIES, R.; ESHLEMAN K. N. Land-use change and hydrologic processes: a major focus for the future. Hydrological Processes, v. 18, p. 2183-2186, 2004. http://dx.doi.org/10.1002/hyp.5584

FINK, M. P.; KRAUSE, S.; KRALISCH, U.; BENDE-MICHL, W; FLÜGEL, A. Development and Application of the Modelling System J2000-S for the EU-Water Framework directive, Advances in Geosciences, v. 11, p. 123-130, 2007. https://hal.archivesouvertes.fr/hal-00297012

FUKA, D. R.; WALTER, M. T.; MACALLISTER, C. A.; DEGAETANO, A. T.; STEENHUIS, T. S.; EASTON, Z. M. Using the Climate Forecast System Reanalysis dataset to improve weather input data for watershed models. Hydrological Processes, 2013. http://dx.doi.org/10.1002/hyp.10073

GAVALDÃO M. Avaliação da percepção ambiental e dos impactos socio-econômicos do projeto "Conservador das Águas" Extrema, Minas Gerais. The Nature Conservancy, p.1-113, 2009.

GREEN, T. R.; ERSKINE, R. H.; ASCOUGH, J. C.; KIPKA, H.; DAVID, O.; COLEMAN, M. L. AgroEcoSystem-Watershed (AgES-W) simulation, scaling and delineation. In: INTERNATIONAL CONGRESS ON ENVIRONMENTAL MODELLING AND SOFTWARE (iEMSs), 8., 15-19 June 2014, San Diego. Proceedings... San Dieg: [s.n.], 2014.

GREEN, T. R.; ERSKINE, R. H.; COLEMAN, M. L.; DAVID, O.; ASCOUGH, J. C.; KIPKA, H. The AgroEcoSystem (AgES) Response-Function Model Simulates Layered SoilWater Dynamics in Semi-Arid Colorado: Sensitivity and Calibration. Vadose Zone Journal, 2015. http://dx.doi.org/10.2136/vzj2014.09.0119

HAY, L.E.; UMEMOTO, M. Multiple-objective stepwise calibration using Luca. Open-File Rep. 2006-1323. Reston: USGS, 2006. ftp://brrcrftp.cr.usgs.gov/pub/mows/pubs/hay_ pubs/hay_pdf/luca_manual.pdf

KRAUSE, P.; BÄSE, F.; BENDE-MICHL, U.; FINK, M.; W. FLÜGEL, W.; PFENNIG. B. Multiscale investigations in a mesoscale catchment - Hydrological modelling in the Gera catchment. Advances in Geosciences, v. 9, p. 53-61, 2006. https://hal.archivesouvertes.fr/hal-00296956

LIMA, G. C. Variabilidade Espacial dos atributos físicos e químicos e índice de qualidade dos solos da sub-bacia das Posses, Extrema (MG), sob diferentes agroecossistemas. 2013. Tese (Doutorado) - Universidade Federal de Lavras, Lavras, 2013

MARENGO, J. A.; JONES, R.; ALVES, L. M.; VALVERDE, M. C. Future change of temperature and precipitation extremes in South America as derived from the PRECIS regional climate modeling system. International Journal of Climatology, v. 29, p. 2241-2255, 2009. http://dx.doi.org/10.1002/joc.1863 
PFENNIG, B.; KIPKA, H.; WOLF, M.; FINK, M.; KRAUSE, P.; FLÜGEL, W. A.. Development of an extended routing scheme in reference to consideration of multidimensional flow relations between hydrological model entities. In: World IMACS; MODSIM09 INTERNATIONAL CONGRESS ON MODELLING AND SIMULATION, 18., 2009, Cairns, Australia. Proceedings... Cairns: 2009. p. 1972-1978.

SAAD, S. I. Modelagem e valoração dos serviços ambientais hidrológicos da recuperação da vegetação no Ribeirão das Posses, Extrema, MG. 2016. Tese (Doutorado em Ciências Ambientais) - Universidade de São Paulo, São Paulo, 2016.

SILVA J. M. da, O serviço ambiental hidrológico das áreas de proteção permanente: um estudo de caso com modelagem numérica em pequena e mesoescala na bacia do Rio Piracicaba. 2014. Tese (Doutorado em Meteorologia) - Instituto de Astronomia, Geofísica e Ciências Atmosféricas, Universidade de São Paulo, 2014.

SOLBÉ, J. F. L. G. (Ed). Effects of Land Use on Fresh Waters. Chichester: Ellis Horwood Publishers, 1986.

TARGA, M. S.; BATISTA G. T. Benefits and legacy of the water crisis in Brazil. Revista Ambiente \& Água, v. 10 n. 2, p. 234 -239, 2015. http://dx.doi.org/10.4136/ambiagua. 1629

WARD, A. D.; TRIMBLE, S. W. Environmental Hydrology. $2^{\text {nd }}$ edition. Boca Raton: CRC Press, 2011. 475p.

ZOLIN, C. A.; FOLEGATTI, M.V.; MINGOTI, R.; PAULINO, J.; SÁNCHEZ-ROMÁN, R. M.; GONZÁLEZ, A. M. O. The first Brazilian municipal initiative of payments for environmental services and its potential for soil conservation, Agricultural Water Management, v. 137, p. 75-83, 2014. http://doi.org/10.1016/j.agwat.2014.02.006 


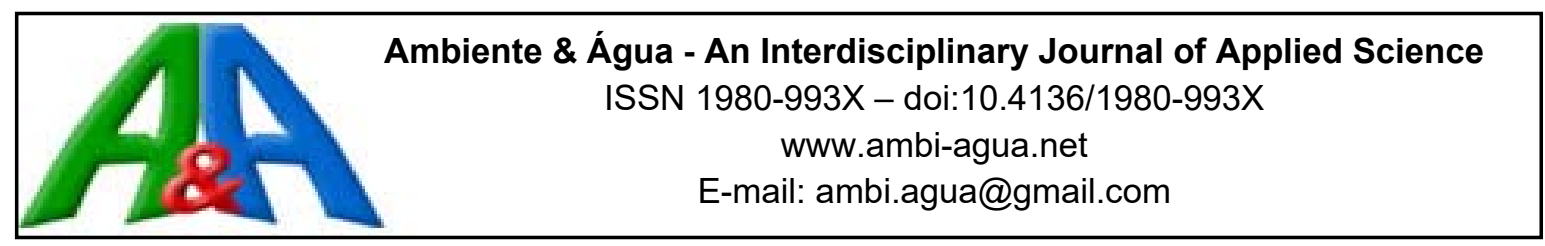

\title{
Objective assessment of ecosystem hydrological services in tropical areas: A Colombian experience in arid and semi-arid zones
}

\author{
doi:10.4136/ambi-agua.2098 \\ Received: 16 Feb. 2017; Accepted: 24 Mar. 2017 \\ Efrain Antonio Domínguez Calle ${ }^{1}$; Jaime Andres Moreno Miranda ${ }^{1}$; \\ Maria Helena Olaya Rodríguez ${ }^{2}$; Juan Felipe Martínez ${ }^{1}$; \\ Cesar Augusto Ruíz Agudelo ${ }^{3}$; Luis Francisco Madriñan ${ }^{4}$; \\ Jaime Burbano Girón ${ }^{1}$; Sergio Esteban Lozano Baez ${ }^{*}$ \\ ${ }^{1}$ Pontificia Universidad Javeriana (PUJ), Bogotá, Colombia \\ ${ }^{2}$ Instituto de Investigación de Recursos Biológicos Alexander Von Humboldt, Bogotá, Colombia \\ ${ }^{3}$ Conservation International Colombia, Bogotá, Colombia \\ ${ }^{4}$ Carbones del Cerrejón Limited, Bogotá, Colombia \\ ${ }^{5}$ Universidade de São Paulo (USP/ESALQ), Piracicaba, Brasil \\ *Corresponding author: e-mail: sergio.lozano@usp.br, \\ e.dominguez@javeriana.edu.co,moreno-jaime@javeriana.edu.co, \\ molaya@humboldt.org.co, juanfmartinezp@gmail.com, \\ cruiz@conservation.org, lfmadrinan@gmail.com, \\ burbano.j@javeriana.edu.co
}

\begin{abstract}
This study presents a methodology to address the challenge of objectively demonstrating Ecosystem Hydrological Services (EHS). A case study is used in the region of the La Guajira Peninsula (Colombia), with a focus on the EHS of water flow regulation. The proposed methodology hypothesizes that EHS that have not been objectively demonstrated lead to failures in the implementation of guidelines of Payments for Ecosystem Services (PES). Following this idea, we have tried to understand and quantify the relationship between vegetation coverage and streamflow regulation. To prove this relationship and the existence of the mentioned EHS in the La Guajira Ecosystem, we determined land cover changes from 2000 to 2013 using the Normalized Difference Vegetation Index (NDVI), and we also quantified the streamflow regulation using hydrological and meteorological time series in the study area. The analysis methods used were insufficient to determine the influence of vegetation on hydric regulation EHS; nevertheless, a greater influence of morphometry was observed in medium-and large-sized basins. Another important finding shows the relevance of selecting an adequate spatial and time resolution when quantifying water flow regulation services and its relationship with land cover characteristics. In this way, this exercise shows the complexity of quantifying EHS. Furthermore, we highlight some aspects that must be taken into account to properly quantify streamflow regulation due to vegetation coverage.
\end{abstract}

Keywords: river regulation, water availability, water flow regulation, water supply. 


\section{Avaliação objetiva dos serviços hidrológicos ecossistêmicos em áreas tropicais: Uma experiência colombiana em zonas áridas e semiáridas}

\section{RESUMO}

O presente estudo apresenta uma metodologia para enfrentar o desafio de mostrar objetivamente os Serviços Hidrológicos Ecossistêmicos (SHE). Um estudo de caso é utilizado na região da Península La Guajira (Colômbia), com ênfase sobre os SHE de regulação do fluxo de água. A metodologia proposta estabelece, como hipóteses, que os SHE não têm sido objetivamente mostrados, levando à falha na implementação de diretrizes de Pagamentos por Serviços Ambientais (PSA). Nesse sentido, objetivou-se compreender e quantificar a relação entre a cobertura vegetal e a regulação da vazão do rio. Para provar essa relação e a existência dos mencionados SHE nos ecossistemas de La Guajira, determinaram-se as mudanças na cobertura vegetal entre 2000 até 2013 utilizando o Índice de Vegetação por Diferença Normalizada (NDVI). Também foi quantificada a regulação da vazão usando séries de tempo hidrológicas e meteorológicas da área de estudo. Os métodos utilizados foram insuficientes para determinar a influência da vegetação na regulação hídrica dos SHE, porém, evidenciou-se uma maior influência da morfometria em bacias de tamanho médio e grande. Outro resultado importante mostra a relevância de se selecionar uma resolução espacial e temporal adequada quando se quantificam serviços de regulação hídrica e sua relação com as características da cobertura vegetal. Desta maneira, esse trabalho mostra a complexidade de se quantificar os SHE. Além disso, realça alguns aspectos que devem ser tomados em conta para quantificar corretamente a regulação da vazão devido à cobertura vegetal.

Palavras-chave: abastecimento de água, disponibilidade de água, regulação do fluxo de água, regulação do rio.

\section{INTRODUCTION}

Ecosystems provide essential services for the well-being of humanity. However, the continuous degradation of ecosystems caused by activities such as agriculture, cattle raising and mining have threatened the supply of these services. One of the main works regarding this concern is the Millennium Ecosystem Assessment (MEA), a program created to "provide an integrated evaluation of the consequences of the changes in ecosystems to human well-being and to analyze available options to improve the preservation of ecosystems and their contribution to meet human needs" (MEA, 2005). According to the MEA (2005), ecosystem services are defined as the benefits that the population obtains from ecosystems and are classified into four categories: (i) provision services that provide goods for the direct use for humankind (i.e., food, drinking water, wood and fibers); (ii) regulation services that maintain a world in which it is biophysically possible to exist (i.e., crop pollination, water damage reduction, climate stabilization); (iii) cultural services that make the world a place where people would like to live (i.e., recreation and aesthetic, intellectual and spiritual inspiration); and (iv) support services, defined as the subjacent ecosystem processes that provide the direct services described above. In particular, the services related to water that are offered by ecosystems have been called Ecosystem Hydrological Services (EHS) and cover the following four categories: water supply, water damage reduction, hydrological and cultural services, and support services related to water (Brauman et al., 2007).

Several authors have defined that the integrated management of ecosystem services in a region requires one to first identify, quantify and evaluate the ensemble of services that can be provided by different ecosystems (Harrison et al., 2010; Holland et al., 2011; Lele, 2009; MEA, 
2005; Quintero, 2010). The results of this process will provide the information base for the development of instruments whose aims would be the conservation of the ecosystems that provide these services, thus assuring human well-being for present and future generations (Fletcher and Breitling, 2012; Kinzig et al., 2011). In the same way, it will allow a more effective integration of these mechanisms for the institutional and political framework when making decisions about land management. (Locatelli et al., 2010; Quintero, 2010; Ferraro, 2011; Lü et al., 2012). One of the most widespread economic instruments for the management of ecosystems services is the Payments for Ecosystem Services (PES), which corresponds to a "voluntary transaction of an ecosystem service where at least a buyer and a seller participate; in that, the ecosystem service is 'well defined' and the service purveyor assures its provision" (Wunder, 2005). Despite its boom, it has been reported that in general, the hydrological PES schemes have not been preceded by a hydrological analysis that evaluates the effects of the activities and decisions promoted by the proposed PES scheme that ensures the supply of the studied service (Roumasset and Wada, 2013). It has been said about the EHS that in several of the world's regions, the abuse and wrongful use of resources, specifically those related to deforestation and forest degradation, along with contamination, increasingly threaten the availability and quality of the EHS, in particular that of the water supply (Calder et al., 2007; MEA, 2005; Quintero, 2010). In this context, the relationship between the vegetation cover, land use and hydrological cycle is widely recognized (Bosch and Hewlett, 1982; Brown et al., 2005; Calder, 1992; 2007; Calder et al., 1997; Farley et al., 2005; Huber, 2008; Iroumé and Huber, 2002; Lara et al., 2009; Little et al., 2009; Ward and Trimble, 2004); but despite recent advances, the understanding of this relationship is still controversial. The results vary between geographical latitudes and can be influenced by different factors (climate seasonality, bio-geographical basin characteristics, and the time and space resolution of developed studies, among others). In general, the results reported by different authors have agreed in asserting that the loss of forest coverage for the establishment of agricultural land or cattle pastures leads to an increment of the peak river discharges during rainy seasons and to a water retention capacity reduction and an increased production of sediments as well. However, these conclusions, especially the ones referring to the services of water supply and water flow regulation, still feed into an enormous discussion (FAO and CIFOR, 2005; Quintero, 2010).

Recently, the Colombian legal system has incorporated laws that favor the function and recognize the benefits of PES; in 2007, Law 1151 was enacted, a framework law for the National Development Plan 2006 - 2010 of Colombia. The structure of this law supports the management of the environment to achieve a sustainable development and includes the commitment of municipalities and departments to dedicate no less than $1 \%$ of its budget to purchase areas of high water availability or to implement PES instruments to ensure their preservation as water providers (Ruiz-Agudelo, 2011). Nevertheless, to implement these regulations appropriately, the formulation of PES schemes should be based on an appropriated quantification of the demanded EHS, and failing in this negatively affects the decisions made for natural resources management (Daily et al., 2009). Accordingly, this study establishes conceptual hydrological elements for the quantification of the EHS of water flow regulation (river regulation), taking as a case study the basins of the San Salvador, Negro, Jerez, Lagarto and Rancheria Rivers and the upper basin of the Cesar River in the Guajira Department, Colombia.

\section{MATERIALS AND METHODS}

According to the above, this document applies the following analysis stages:

a) Characterization of the state and changes in vegetation land cover through the NDVI;

b) Hydrologic quantification of streamflow regulation; 
c) Search of streamflow regulation-NDVI relationships; and

d) Ranking of ecosystem factors that influence the analyzed streamflow regulation.

For stages (a) and (b), the concepts of Normalized Difference Vegetation Index and regulation coefficient are introduced, but basin morphometric characteristics are also presented, allowing for the further determination of the morphometric characteristics that control the surface runoff and water flow regulation processes.

\subsection{Study area}

The study area is approximately $7.000 \mathrm{~km}^{2}$ and belongs to the "La Guajira" peninsula in Colombia. The range of geographical characteristics is quite varied and goes from the altitude of 5.575 meters above the sea level in the Sierra Nevada de Santa Marta to the coastal zone of the Caribbean Sea. The ocean influence and the fact that this territory is a part of a peninsular zone, in which the largest desert area of Colombia is located, makes it a region with a very high hydrological and ecosystem diversity. The variety of hydrological regimes within a relatively small area facilitates the identification of the ecosystem characteristics that influence the hydrological variables that are also the basis for EHS quantification.

To establish the dependency of water flow regulation variables on vegetation coverage, 23 watersheds were studied. These watersheds were obtained throughout supervised basin delineation using the ArcHydro tool incorporated in the extension HEC-GeoHMS tools in ARCGIS 10 (USACE and HEC 2011). As outlet points, hydrological stations were used (red points, Figure 1). Precipitation in the area is monitored by a meteorological network. Rainfall stations are shown in black hexagons.

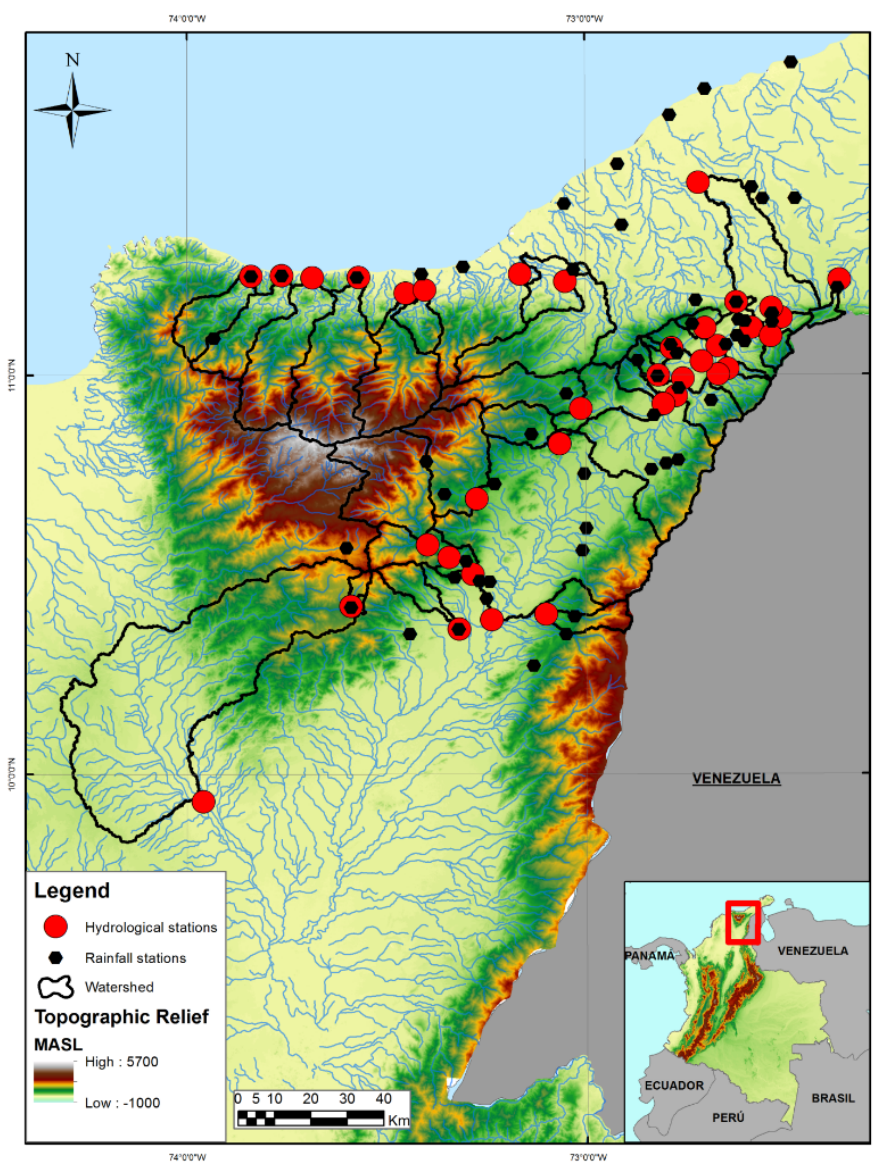

Figure 1. Spatial distribution of hydrological stations and watersheds studied. 


\subsection{The Normalized Difference Vegetation Index (NDVI)}

This index varies between values of -1 and +1 , where dense vegetation presents values between 0.5 and 0.7 (Holben, 1986). In this sense, the high index values are directly related to the content of chlorophyll, the phenological dynamics, the amount of $\mathrm{CO}_{2}$, the amount of rainfall received and the potential evapotranspiration (Chuvieco, 2006). It is a reliable index that has extensive use in the description of biophysical parameters of vegetation cover. The NDVI is calculated by the Near-Infrared Band $\left(B_{I R C}\right)$ and the visible red band $\left(B_{R}\right)$ as Equation 1.

$$
\mathrm{NDVI}=\frac{B_{I R C}-B_{R}}{B_{R}+B_{I R C}}
$$

For the calculation, we used a total of 298 images from the MODIS (Moderate Resolution Imaging Spectroradiometer) sensor, downloaded using the GloVis (USGS Global Visualization) tool. The images corresponded to the product MOD13Q1 taken from February 18, 2000 through January 17, 2013, every 16 days, with a spatial resolution of 250 meters.

To understand the spatial variability and dynamics of the NDVI vegetation coverage fields, temporal series were constructed in each one of the watersheds. The geoprocessing tasks performed to build such series included a) transformation into the spatial reference system MAGNA-SIRGAS and b) obtaining the proportion of four main categories of land coverage in each watershed according to the NDVI thresholds shown in Table 1 (Holben, 1986; Chuvieco, 2006).

Table 1. NDVI ranges used to classify the type of coverage according to the proportion and type of vegetation.

\begin{tabular}{ll}
\hline NDVI Range & \multicolumn{1}{c}{ Type of cover } \\
\hline$-1.0-0,0$ & Barren areas \\
$0.0-0.5$ & Vegetation cover \\
$0.5-0.7$ & Dense vegetation \\
$0.7-1.0$ & Very dense vegetation \\
\hline
\end{tabular}

These tasks allowed us to obtain 144 time series of the NVDI, 4 for each of the 36 afferent areas and each with a length of 298 registries. This analysis was performed using scripts that were developed in Python 2.6 and its scientific programming modules Numpy, Scipy, OGR and GDAL. Finally, we considered linear trend tests, the least squares test and the Mann-Kendall test (Salmi et al., 2002).

\subsection{Regulation coefficient}

The regulation coefficient is a quantitative measure of the streamflow regulation using data from a hydrological station, which is defined as Equation 2.

$$
C_{R}=\frac{A_{p}}{A_{T}}
$$

where:

$A_{p}$ and $A$ T are obtained from the flow duration curve (Figure 2), 
$A_{p}$ represents the partial area contained below the line of the mean flow, and

Aт is the total area under the whole curve. The regulation coefficient is always less than or equal to one, and according to Samokhin and Salaviov (1980), its values of 0.6 to 0.8 are characteristic of the surface currents regulated by lakes or reservoirs (artificial or natural) and by the currents located in geographical zones with a high level of rainfall saturation. The coefficient values of regulation from 0.2 to 0.1 are characteristic of currents with a very low regulation capacity.

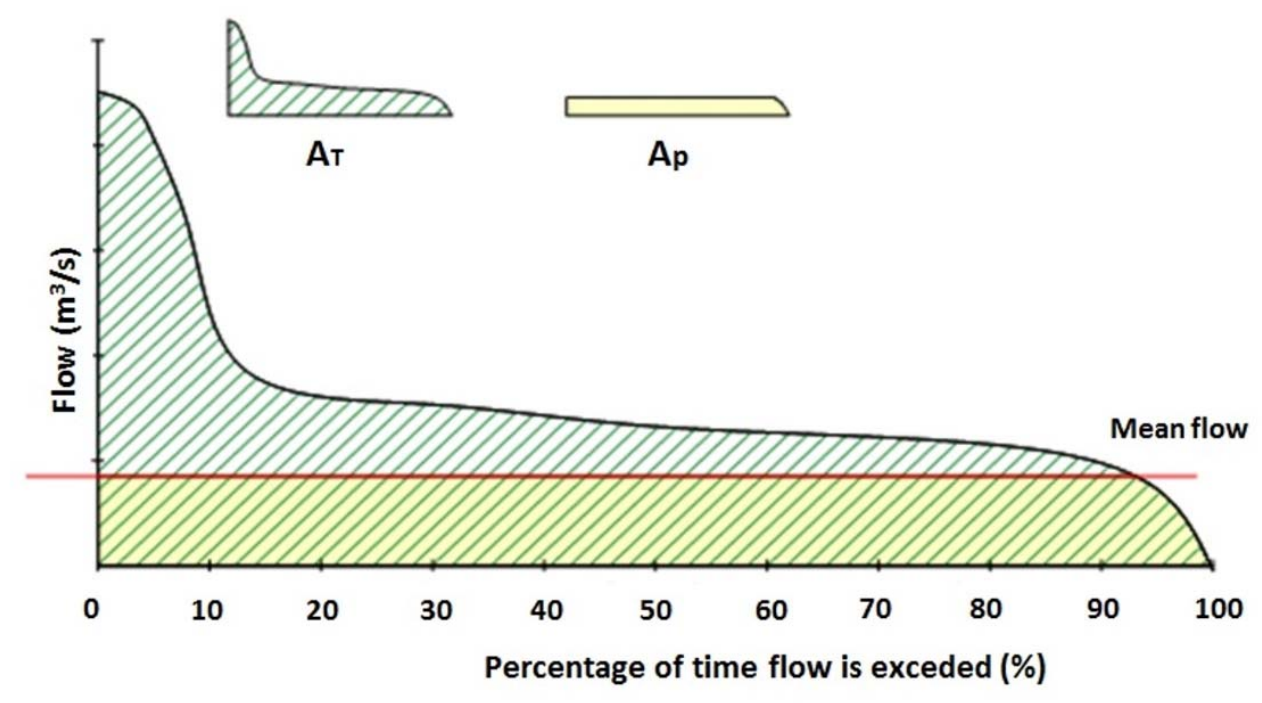

Figure 2. Determination of the regulation coefficient from the flow duration curve.

For this article, the authors propose a classification of the different regulation values as follows: Very high $(0.81-1.00)$, High $(0.71-0.80)$, Medium $(0.51-0.70)$, Low $(0.31-0.50)$ and Very low $(0.00-0.30)$. Taking as a base point the previous definition, the regulation coefficient was calculated for each one of the hydrological series available using data at a daily resolution. However, there are different ways to calculate the regulation coefficient that depend mainly on how the flow duration curve is built. One way to calculate the regulation coefficient is to build only one flow duration curve for each station, using the full record of the time series of daily flow, and the multi-annual regulation coefficient is obtained as a result. In a second method, one flow duration curve is built for each year and each series, and the annual dynamic of the regulation coefficient is obtained as a result. The third method is similar to the second, but for every hydrologic station case, one regulation coefficient is calculated for each month based on the construction of a flow duration curve for every month. In this way, the monthly dynamic of the regulation coefficient was obtained.

Following these three methods of calculation, we obtained the following:

a) For the first calculation method, 23 multi-annual regulation coefficients, one for each hydrological station.

b) For the second method, 23 series that show the annual temporal evolution of the regulation coefficient on each hydrological station.

c) For the third method, 23 series that show the monthly temporal evolution of the regulation coefficient on each hydrological station. 
To compare the regulation coefficients from the different methodologies, three versions for the multi-annual regulation coefficients were used. To obtain the multi-annual values from the second and third methods, the respective series were aggregated.

\subsection{Possible control factors of the regulation coefficient}

Having a quantitative characterization of the streamflow regulation for the watershed calculated on the outlet points (hydrological stations), we proceeded to look for the factors that may affect this magnitude. A correlation analysis was performed between the regulation coefficient values, the NDVI index and the morphometric characteristics of each watershed. The morphometric parameters for each of the 23 watersheds were determined using the SRTM digital elevation model of a 90-meter cell size (CGIAR-CSI, 2012; Sanders, 2007). Scripts in Python and $\mathrm{R}$ were developed to calculate the morphometric parameters. In Table 2, the Pearson correlation coefficient between the multi-annual regulation coefficient and the morphometric parameters is shown ( $\mathrm{p}$-value $\leq 0,05$ ). A detailed explanation of the calculation of these parameters is given in Samokhin and Saloviov (1980).

Table 2. Correlation between the morphometric parameters on each of the areas of surface runoff and the regulation coefficient.

\begin{tabular}{llcc}
\hline \multicolumn{1}{c}{ Symbol } & \multicolumn{1}{c}{ Morphometric parameters } & P-Value & $\begin{array}{c}\text { Correlation } \\
\text { coefficient }\end{array}$ \\
\hline$\sigma$ & Elongation or form coefficient & 0.476 & 0.15 \\
$\mathrm{~A}$ & Basin area & 0.726 & 0.07 \\
$\mathrm{~B}$ & Mean width of the basin & 0.514 & 0.14 \\
$\mathrm{D}$ & Hydrographic network density & $0.003^{*}$ & -0.57 \\
$H_{\text {basin }}$ & Mean height of the basin & $0.000^{*}$ & 0.76 \\
$H_{\text {riverbed }}$ & Mean height of the principal riverbed & $0.000^{*}$ & 0.69 \\
$H_{\text {dis }}$ & Dissection depth of the basin & $0.007^{*}$ & 0.52 \\
$I_{\text {riverbed }}$ & Median slope of the principal riverbed & $0.042^{*}$ & 0.41 \\
$I_{\text {basin }}$ & Mean slope of the basin & $0.000^{*}$ & 0.72 \\
$\mathrm{~N}$ & Order number of the basin & $0.001^{*}$ & 0.61 \\
$N_{\text {dis }}$ & Relief dissection level & $0.023^{*}$ & 0.45 \\
$k_{c}$ & Compactness coefficient & 0.540 & -0.13 \\
$K_{S}$ & Sinuosity coefficient & 0.698 & -0.08 \\
$L_{l}$ & Linear distance from the river origin to its rivermouth & 0.271 & 0.23 \\
$L_{\text {Lad }}$ & Mean length of the basin's slopes & $0.005^{*}$ & 0.55 \\
$L_{t}$ & Principal river length & 0.238 & 0.25 \\
$\mathrm{Q}_{\text {med }}$ & Mean flow & $0.001^{*}$ & 0.61 \\
$R b$ & Bifurcation coefficient & 0.299 & 0.22 \\
\hline
\end{tabular}

*Significant correlation $(\alpha=0,05)$. 
Subsequently, the collinearity analysis was conducted between the 9 morphometric parameters with statistically significant linear correlations. Then, the hydrographic network density (D), the mean height of the basin $\left(\mathrm{H}_{\text {basin }}\right)$ and the mean flow $\left(\mathrm{Q}_{\mathrm{med}}\right)$ parameters were selected to build a multiple regression to determine the regulation coefficient.

\subsection{Variability of precipitation series}

Simultaneously, there are local and global processes influencing rainfall regimes in different world regions (Huntington, 2006). All these processes of global change seem to influence not only the average magnitude of rainfall but also its variance (Haan Thomas, 1977; Kovalenko, 1993; Rozhdenstvenskiy and Chevotariov, 1974). The relationship between rainfall and surface runoff has been widely studied; in fact, this is the keystone that supports rainfall-runoff models (Chow et al., 1994; Clarke, 1973; Domínguez and Rivera, 2010). Changes in rainfall will likely affect streamflow. However, it is also well known that a basin works as a filter of the precipitation signal, and just a fraction of the precipitation variability reaches stream flows.

As a metric of how much a basin regulates the precipitation signal before it becomes a streamflow, we compared the precipitation regulation coefficients vs. the streamflow regulation coefficients. To achieve this type of analysis, the stations with rainfall registry were identified inside each analyzed watershed, and in cases without measurements, we associated the closest rainfall station. Then, to understand the role of basin regulation, the following procedure was developed:

a) A linear correlation and regression analysis between the regulation coefficients of the stream time series and the regulation coefficients of the rainfall series was performed.

b) The correlation coefficient between each of the series of the proportion of NDVI and the streamflow series for each of the 23 areas of surface runoff was determined. This comparison was performed using a monthly and annual resolution of time series.

c) From each of the regulation coefficients of the streams, we subtracted the obtained regulation coefficients from the corresponding rainfall series. In this way, a high difference means high basin regulation; in contrast, low differences mean low basin regulation. Then, a correlation analysis was performed using the series of regulation coefficient differences vs. NDVI series.

\section{RESULTS AND DISCUSSION}

\subsection{The Normalized Difference Vegetation Index (NDVI)}

The NDVI values between 0.7 and 1.0 (Areas with very dense vegetation) appear to be dominant for the 2000- to 2012-time period, sharing $62 \%$ of the study area. In the range between 0.5 and 0.7 (areas with dense vegetation), $23 \%$ of the area is found on average; with regard to the values between 0.0 and 0.5 (areas without dense vegetation cover), the share reaches $15 \%$. The NDVI values lower than 0.0 (Barren areas) occupy a low share, on the order of $0.2 \%$.

The barren areas, despite registering a small increasing trend, lacked statistical significance, at least to reach a 95\% confidence level. For areas with vegetation cover, the Mann Kendall test as well as the linear regression trend analysis show negative trends $(\alpha=0.05)$; in this case, the decreasing rate was $-0.5 \%$ annually. For areas with dense vegetation cover, even though the Mann Kendall test showed a significant negative trend $(\alpha=0.05)$, the slope coefficient in this trend defined by linear regression showed a p-value of 0.06 . As for the multi-annual monthly behavior of the vegetation cover, there is a clear pattern differentiating the vegetation cover in the months of February, March and April from the coverage pattern for the rest of the year. In these months, the proportion of the area with NDVI between 0.7 and 1.0

Rev. Ambient. Água vol. 12 n. 3 Taubaté - May / Jun. 2017 
decreases on average to $33 \%$ of the basin's area. In contrast, areas with NDVI between 0.0 and 0.5 increase to $33 \%$. This behavior seems highly conditioned by the rainfall regime, which has its first peak of the year between the months of March through April. Although the second high-water season occurs between the months of October and December, with higher rainfall values, there is no evidence of the same behavior in these months (Figure 3).

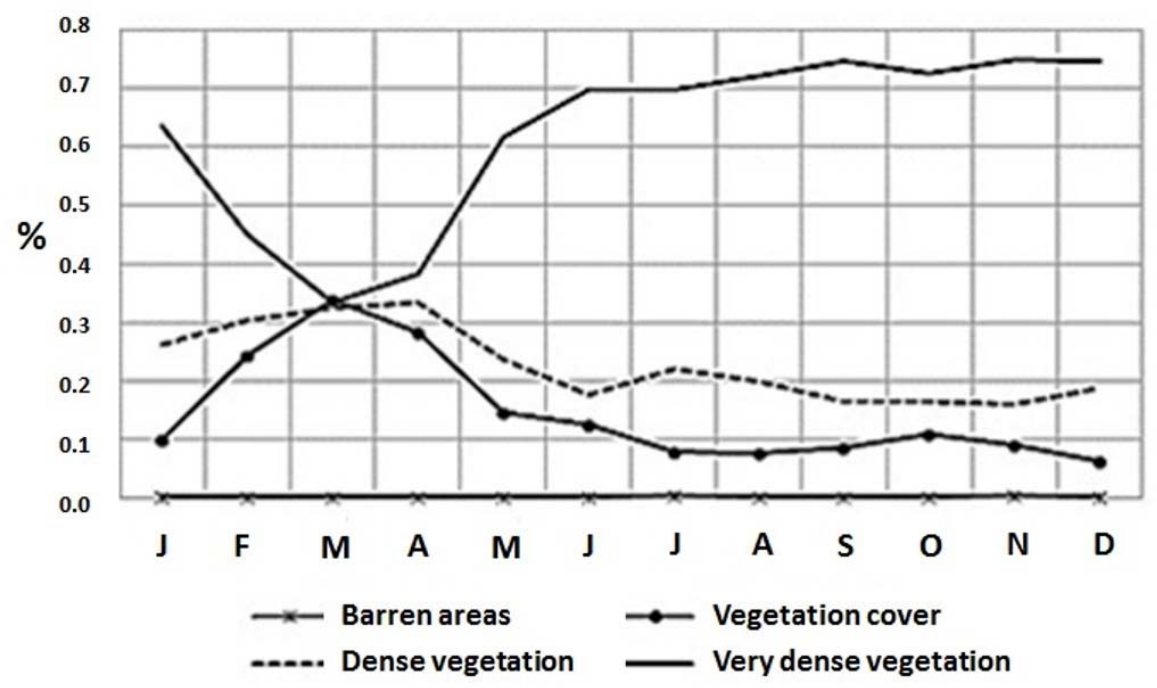

Figure 3. Monthly multi-annual distribution of area proportions by ranges of NDVI.

\subsection{Regulation coefficient}

The regulation coefficient magnitudes vary in accordance with the temporal resolution to which the flow duration curve was built. In general, the regulation coefficient magnitude increases with the flow duration curve's temporal resolution. In this way, the lesser regulation coefficient is obtained for the flow duration curve that is built for the multi-annual interval, and the biggest is obtained through the monthly regulation coefficient series, leaving an intermediate point of the regulation coefficient that is obtained as the average of the series of annual regulation coefficients. It must be noted that the regulation coefficients of these three methodologies scale linearly (Figure 4).

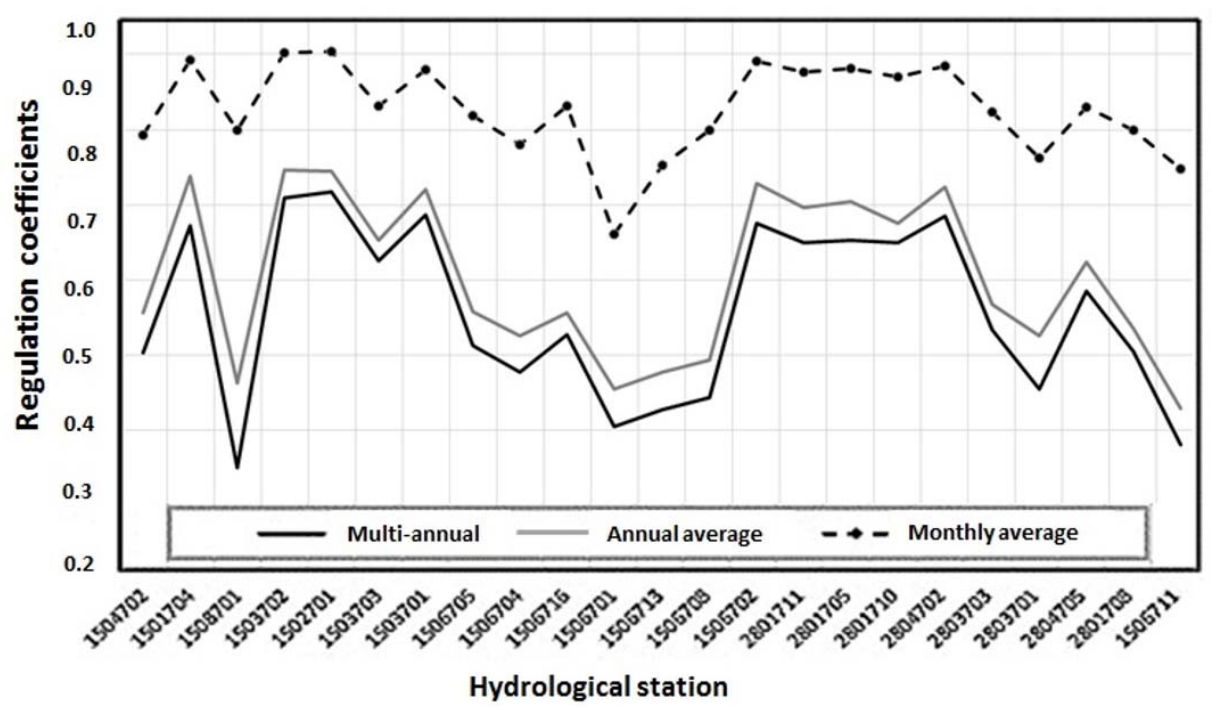

Figure 4. Regulation coefficients obtained from the three-stream aggregation methodologies of the series. 
Differences in the regulation coefficients obtained by the three methodologies seem to obey the fact that a monthly grouping of daily stream data has less variance than does one from annual and multi-annual groupings. It is widely known that the regulation coefficient depends in a significant way on the variance of the data used to calculate it.

\subsection{Possible factors controlling the regulation coefficient}

The analysis between the proportion series of the area occupied by NDVI ranges and the regulation coefficient series did not find statistically significant linear correlations. In the case of the correlation analysis of NDVI with the regulation coefficient through a monthly series, the result of a low correlation is not unexpected. To begin with, because of the positive bias of the regulation coefficient magnitude when it is calculated as a monthly resolution, it is correlated with a low variability magnitude (the monthly regulation coefficient) and with very high variability (the monthly NDVI). From this contrast, we can only expect a low linear correlation. On the other hand, in the case of the linear correlation analysis for the annual series of the regulation coefficient and the NDVI index, it might be explained by the annual NDVI being a bad indicator of the vegetation cycle. This result is a consequence of most of the vegetation dynamics occurring in the hydrological year, and using the mean NDVI value for the whole year could hide this property.

Additionally, even though the set of data of the NDVI has gone through a process of quality control, there are still problems that must be considered when using this type of study, such as the presence of mixed pixels (pixels that have more than one coverage type affecting the values of NDVI), registry deficiency (appearing as a result of mistakes when re-calculating the satellite position at the time of the image being recorded), comparison of values of the NDVI amongst pixels (factors such as plant architecture arrangements, canopy interactions, height, species composition, vegetation strength, leaf properties and vegetation stress can significantly affect the information of remote sensors, making it so that equal values of NDVI may represent different conditions for different vegetation communities, recommending previous knowledge in these elements of the study area) and quality information about spatial location (bigger mistakes may occur close to the equator because of the variations in the angle of the solar zenith in the majority of the satellite registry) (Pettorelli et al., 2005).

It is also important to take into consideration the fact that even if the image availability of MODIS-NDVI, which provides a high-quality series of time data, represents a great advance in the monitoring of the annual changes in the earth coverage and vegetation condition in large geographical regions, it also brings with it disadvantages and spatial resolution limitations (250 $\mathrm{m}$ ) because minor event changes to approximately 1.5 hectare would have a low probability of being detected. This issue is problematic for monitoring the changes in zones of riparian dampening and other events of small scale conversion that could be associated with high value ecological resources such as the evaluated EHS in this study.

The good relationship between the drainage density parameters, basin mean height and mean flow with the regulation coefficient can be explained more easily in some cases than in others. As for the drainage density, the negative correlation seems very clear; it is to be expected that in the measure in which a basin shows a higher length of currents per unit of area, the superficial surface runoff will flow easily, concentrating in the stream quickly, which will create more severe/sharp peaks of flooding. In contrast, a low drainage density indicates that the water should drain for a longer time over the terrain surface, in which the roughness coefficients are usually bigger than in the main stream, creating in this way higher friction to the water movement, slowing its concentration in the main stream and thus conducting a smoothed peak raise (Chow, 2009). In the first instance, it is not expected that the basin's mean height would have a positive influence on the regulation coefficient; on the contrary, an elevated mean height

Rev. Ambient. Água vol. 12 n. 3 Taubaté - May / Jun. 2017 
may indicate high slopes in which the superficial surface runoff is developed with high speeds. However, on the analyzed study area, it was found that the weight of this problem is not very significant ( $7.2659 \mathrm{E}^{05}$ vs. 0.77492865 corresponding to drainage density), and when analyzing the spatial distribution of the hydrological stations for which the regulation coefficient was calculated, it was found that the sloped and steep relief areas of the study area conserved vegetation coverage in such a way so that the small influence of the median height of the basin could be attributed indirectly to the EHS offered by the vegetation.

Finally, the multiple regression between the three selected parameters $\left(D, H_{\text {basin }}\right.$ and $\mathrm{Q}_{\text {med }}$ ) proved to be statistically significant. According to this result, morphometrics can explain close to $77 \%$ of the regulation coefficient of the streams time series, and it is proposed that the remaining 23\% should be explained by other factors such as vegetation and ground characteristics (Table 3).

Table 3. Multiple regression parameters for the calculation of $C_{R}$.

\begin{tabular}{lllllll}
\hline & Coefficient & Typical error & Statistic $\mathrm{t}$ & Probability & Lower 95\% & Higher 95\% \\
\hline Interception & 0.73695409 & 0.11264871 & 6.54205547 & $2.2452 \mathrm{E}-06$ & 0.501973 & 0.97193517 \\
$\mathrm{D}$ & -0.77492865 & 0.25113784 & -3.08567064 & 0.00583122 & -1.298793 & -0.2510643 \\
$\mathrm{H}_{\text {basin }}$ & $7.2659 \mathrm{E}^{-05}$ & $2.3527 \mathrm{E}^{-05}$ & 3.08832177 & 0.0057963 & $2.3583 \mathrm{E}-05$ & 0.00012174 \\
$\mathrm{Q}_{\text {med }}$ & 0.00330213 & 0.00131922 & 2.50310248 & 0.02109332 & 0.0005503 & 0.00605397 \\
\hline
\end{tabular}

\subsection{Variability of precipitation series}

According to the trend and the frequency distribution of the quotients between stream and rainfall, the regulation coefficients of the stream series are two to five times bigger than the regulation coefficients measured on the rainfall time series (Figure 5).

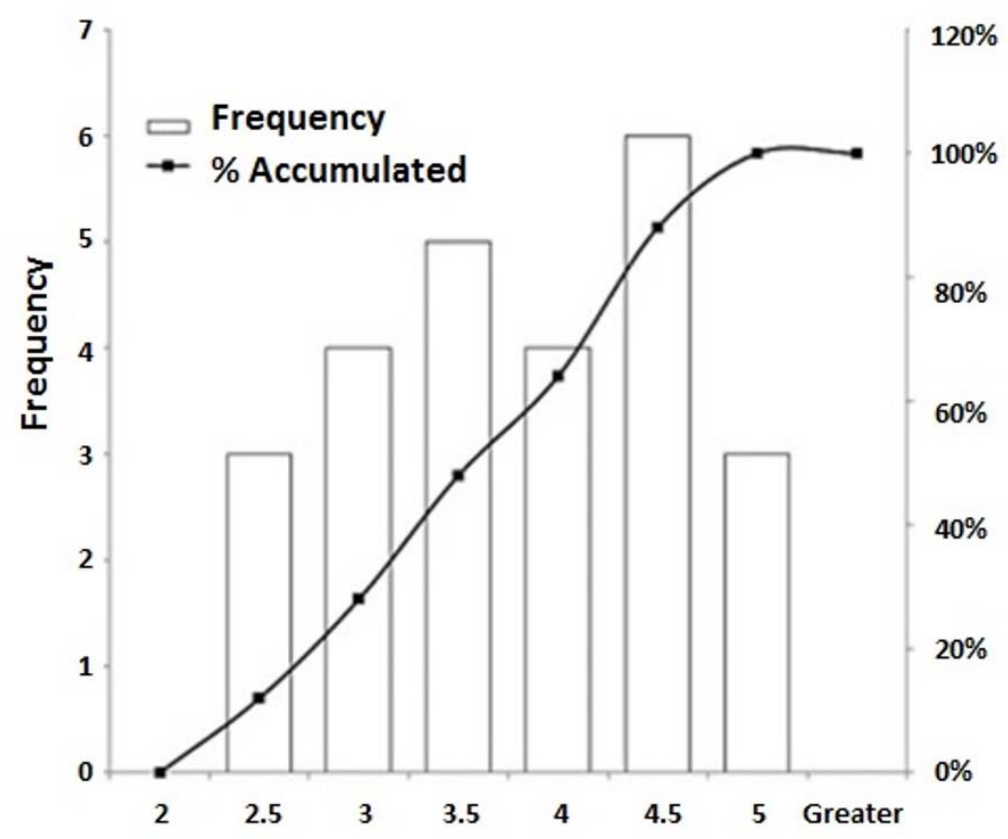

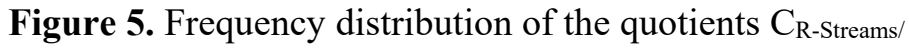
$\mathrm{C}_{\mathrm{R} \text { rainfall. }}$

This result, together with the influence of the morphometries on the regulation coefficient variability of the streams time series, indicates that in the study area, the basin as a system 
executes an attenuating filtering action that diminishes the rainfall variability that comes into the system. According to the proposed hypothesis, it was expected that as a result of steps (b) and (c), part of the unexplained variability could be assigned to the basin's vegetation coverage. In this sense, the applied correlation analysis did not show any significant linear correlation between the NDVI indexes and the regulation coefficient differences determined in step (c). Despite this result, it cannot be sustained that vegetation coverage does not have any effect on streamflow regulation, and it can only be said that there is no overwhelming evidence found to prove this ecosystem service. However, given the relationship between morphometric and streamflow regulation and, in particular, the positive linear relationship of the mean height of the basin with the regulation coefficients, it can be indirectly attributed to vegetation. This assertion takes into account the fact that mountain and hill landscapes have a mean height in the study area that is higher than flat landforms, and they have been higher in the last transformation of vegetation coverage. This result indicates that vegetation coverage also has an influence on the regulation coefficient magnitude of the stream series. On the other hand, this study did not contemplate the influence of the soil characteristics over the magnitudes of the regulation coefficient. The soil-vegetation system establishes a unit that surely produces synergy into the streamflow regulation of the basins; however, for the studied basins, the existing studies do not provide adequate information on the soil and its humidity dynamic to allow one to tie together the soil properties. Recent publications suggest that the satellite information on land humidity is beginning to have precision levels that convert it into relevant information for the analysis of the influence on the soil-vegetation system over the regulation coefficient magnitudes.

\section{CONCLUSIONS}

This study quantitatively determines the streamflow regulation and shows the preponderance of influences that have morphometric basin properties. This study also shows the difficulties of establishing a relationship between vegetation coverage and streamflow regulation as an ecosystem service. This same analysis is not conclusive in the determination of additional factors to the morphometric that control the regulation coefficient magnitudes obtained for the analyzed hydrologic stations. The analysis methods used were insufficient to determine the influence of vegetation on the hydric regulation EHS. This result can be attributed to congruence problems in the temporal resolution in the regulation coefficient of the series and the NDVI and to the presence of mistakes in the values of the latter due to mixed pixels and the other elements mentioned above, together with its limitations in spatial resolution. Finally, the findings and conclusions elaborated during this study allow us to suggest the existence of a vacuum at the time of the formulation of Payments for Ecosystem Services schemes. It is, therefore, necessary to ponder the hypothesis that is usually applied to sustain these schemes. According to the experience shown here, it is suggested that the decision makers in this matter include a project stage that looks for a clear and overwhelming demonstration of the ecosystem hydrological services in a permanent manner.

\section{REFERENCES}

BOSCH, J. M.; HEWLETT, J. D. A review of catchment experiments to determine the effect of vegetation changes on water yield and evapotranspiration. Journal of Hydrology, v. 55, p. 3-23, 1982. https://doi.org/10.1016/0022-1694(82)90117-2

Rev. Ambient. Água vol. 12 n. 3 Taubaté - May / Jun. 2017 
BRAUMAN, K. A.; DAILY, G. C.; DUARTE, T. K.; MOONEY, H. A. The Nature and Value of Ecosystem Services: An Overview Highlighting Hydrologic Services. Annual Review of Environment and Resources, v. 32, n. 1, p. 67-98, 2007. http://dx.doi.org/10.1146/annurev.energy.32.031306.102758

BROWN, A.; ZHANG, E.; MCMAHON, L.; WESTERN, A. W.; VERTESSY, R. A. A review of paired catchment studies for determining changes in water yield resulting from alterations in vegetation. Journal of Hydrology, v. 310, p. 28-61, 2005. http://dx.doi.org/10.1016/j.jhydrol.2004.12.010

CALDER, I.; HOFER, T.; VERMONT, S.; WARREN, P. Hacia una nueva comprensión de los bosques y el agua. Unasylva, v. 58, p. 3-10, 2007.

CALDER, I. R. A model of transpiration and growth of eucalyptus plantation in water-limited conditions. Journal of Hydrology, v. 30, 1-15, 1992. https://doi.org/10.1016/00221694(92)90099-H

CALDER, I. R. Forest and water - ensuring forest benefits outweigh water costs. Forest $\begin{array}{llllll}\text { Ecology and Management, } & \text { v. 251, p. 110-120, }\end{array}$ http://dx.doi.org/10.1016/j.foreco.2007.06.015

CALDER, I. R.; ROSIER, P. T. W.; PRASAN, K. T.; PARAMESWARAPPA, S. Eucalyptus water use greater than rainfall input a possible explanation from southern India. Hydrological \& Earth System Science, v. 1, p. 249-256, 1997.

CHOW, V. T. Open-Channel hydraulics. Caldwell: The Blackburn Press, 2009. 700 p.

CHOW, V. T.; MAIDMENT, D. R.; MAYS, L. W. Applied hydrology. Bogotá: Mc Graw Hill, 1994. 584 p.

CHUVIECO, E. Teledetección ambiental. Barcelona: Editorial Ariel, 2006. 586 p.

CLARKE, R. T. A review of some mathematical models used in hydrology, with observations on their calibration and use. Journal of Hydrology, v. 19, n. 1, p. 1-20, 1973. https://doi.org/10.1016/0022-1694(73)90089-9

DAILY, G. et al. Ecosystem services in decision making: time to deliver. Frontiers in Ecology and the Environment, v. 7, p. 21-28, 2009. http://dx.doi.org/10.1890/080025

DOMÍNGUEZ, E.; RIVERA, H. A Fokker-Planck-Kolmogorov equation approach for the monthly affluence forecast of Betania hydropower reservoir. Journal of Hydroinformatics, v. 12, n. 4, p. 486-501, 2010.

FAO; CIFOR. Forests and floods: drowning in fiction or thriving on facts? Bangkok, 2005.

FARLEY, K. A.; JOBBAGY, E. G.; JACKSON, R. B. Effects of afforestation on water yield: a global synthesis with implications for policy. Global Change Biology, v. 11, n. 10, p. 1565-1576, 2005. http://dx.doi.org/10.1111/j.1365-2486.2005.01011.x

FERRARO, P. The future of payments for environmental services. Conservation Biology, v. 25, n. 6, p. 1134-1138, 2011. http://dx.doi.org/10.1111/j.1523-1739.2011.01791.x

FLETCHER, R.; BREITLING, J. Market mechanism or subsidy in disguise? Governing payment for environmental services in Costa Rica. Geoforum, v. 43, p. 402-411, 2012. http://dx.doi.org/10.1016/j.geoforum.2011.11.008 
HAAN THOMAS, C. Statistical methods in hydrology. Iowa: Iowa State University Press, 1977. $378 \mathrm{p}$.

HARRISON, P. A. et al. Identifying and prioritizing services in European terrestrial and freshwater ecosystems. Biodiversity and Conservation, v. 19, n. 10, p. 2791-2821, 2010. http://dx.doi.org/10.1007/s10531-010-9789-x

HOLBEN, B. N. Characteristics of maximum-value composite images from temporal AVHRR data. International Journal of Remote Sensing, v. 7, p. 1417-1434, 1986. http://dx.doi.org/10.1080/01431168608948945

HOLLAND, R. A. et al. Spatial covariation between freshwater and terrestrial ecosystem services. Ecological applications, v. 21, n. 6, p. 2034-2048, 2011. http://dx.doi.org/10.1890/09-2195.1

HUBER, A. Effect of Pinus radiata plantations on water balance in Chile. Hydrological Processes, v. 148, p. 142- 148, 2008. http://dx.doi.org/10.1002/hyp.6582

HUNTINGTON, T. Evidence for intensification of the global water cycle: review and synthesis. Journal of Hydrology, v. 319, p. 83-95, 2006. http://dx.doi.org/10.1016/j.jhydrol.2005.07.003

IROUMÉ, A.; HUBER, A. Comparison of interception losses in a broadleaved native forest and aPseudotsuga menziesii (Douglas fir) plantation in the Andes Mountains of southern Chile. Hydrological Processes, v. 16, n. 12, p. 2347-2361, 2002. http://dx.doi.org/10.1002/hyp.1007

KINZIG, A. P. et al. Paying for ecosystem services - promise and peril. Science, v. 334, p. 603-604, 2011. http://dx.doi.org/10.1126/science.1210297

KOVALENKO, V. Modelling of hydrological processes. Saint Petersburg: Guidrometeoizdat, 1993. 255 p.

LARA, A. et al. Assessment of ecosystem services as an opportunity for the conservation and management of native forests in Chile. Forest Ecology and Management, v. 258, n. 4, p. 415-424, 2009. http://dx.doi.org/10.1016/j.foreco.2009.01.004

LELE, S. Watershed services of tropical forests: from hydrology to economic valuation to integrated analysis. Current Opinion in Environmental Sustainability, v. 1, n. 2, p. 148-155, 2009. http://dx.doi.org/10.1016/j.cosust.2009.10.007

LITTLE, C.; LARA, A.; MCPHEE, J.; URRUTIA, R. Revealing the impact of forest exotic plantations on water yield in large scale watersheds in South-Central Chile. Journal of Hydrology, v. 374, p. 162-170, 2009. http://dx.doi.org/10.1016/j.jhydrol.2009.06.011

LOCATELLI, B. et al. Ecosystem services and hydroelectricity in Central America: modelling service flows with fuzzy logic and expert knowledge. Regional Environmental Change, v. 11, n. 2, p. 393-404, 2010. http://dx.doi.org/10.1007/s10113-010-0149-x

LÜ, Y.; LIU, Y.; FU, B. Ecosystem service: from virtual reality to ground truth. Environmental Science \& Technology, v. 46, p. 2492-2493, 2012. http://dx.doi.org/10.1021/es300475w

MILLENNIUM ECOSYSTEM ASSESSMENT - MEA. Ecosystems and human well-being: synthesis. Washington, D.C.: Island Press, 2005. 155 p. 
PETTORELLI, N. Using the satellite-derived NDVI to assess ecological responses to environmental change. Trends in Ecology \& Evolution, v. 20, n. 9, p. 503-510, 2005. http://dx.doi.org/10.1016/j.tree.2005.05.011

QUINTERO, M. Servicios ambientales hidrológicos en la Región Andina. Lima: CONDESAN, 2010. $277 \mathrm{p}$.

ROUMASSET, J.; WADA, C. A. A dynamic approach to PES pricing and finance for interlinked ecosystem services: Watershed conservation and groundwater management. Ecological Economics, v. 87, p. 24-33, 2013. http://dx.doi.org/10.1016/j.ecolecon.2012.11.023

ROZHDENSTVENSKIY, A. V.; CHEVOTARIOV, A. I. Statistical methods in hydrology. Leningrad: Guidrometeoizdat, 1974. 424 p.

RUIZ-AGUDELO, C. Metodologías para mecanismos de conservación en comunidades rurales de Colombia, a través de esquemas de pago por servicios ambientales. Revista Facultad de Ciencias Básicas Universidad Militar Nueva Granada, v. 7, n. 2, p. 276 295, 2011. http://dx.doi.org/10.18359/rfcb.2106

SALMI, T.; MÄÄTTÄ, A.; ANTTILA, P.; RUOHO-AIROLA, T.; AMNELL, T. Detecting trends of annual values of atmospheric pollutants by the Mann-Kendall test and Sen's Solpe estimates - the Excel template application Makesens. Helsinki: Ilmatieteen laitos; Meteorologiska Institutet; Finnish Meteorological Institute, 2002.

SAMOKHIN, A.; SALOVIOV, N. Hydrology handbook. Leningrad: Hydrometeoizdat, 1980.

SANDERS, B. F. Evaluation of on-line DEMs for flood inundation modeling. Advances in Water Resources, v. 30, n. 8, p. 1831-1843, 2007. http://dx.doi.org/10.1016/j.advwatres.2007.02.005

THE CGIAR CONSORTIUM FOR SPATIAL INFORMATION. SRTM 90m Digital Elevation Data. 2012. Available in: http://srtm.csi.cgiar.org. Access in: Oct. 2015.

WARD, A. D.; TRIMBLE, S. W. Environmental hydrology. London: Lewis Publishers; New York: CRC Press Company, 2004. 472 p.

WUNDER, S. Payments for environmental services: some nuts and bolts. Jacarta: CIFOR, 2005. http://dx.doi.org/10.17528/cifor/001760 


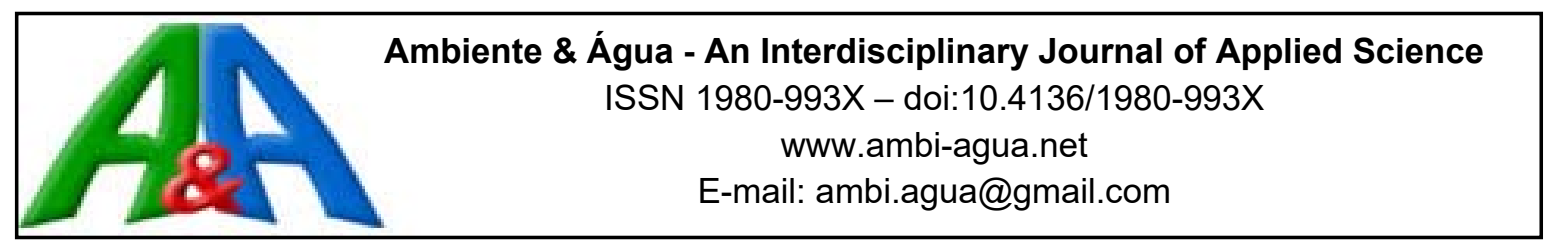

\title{
Solid phase extraction using molecular imprinting polymers (MISPE) for the determination of estrogens in surface water by HPLC
}

\author{
doi:10.4136/ambi-agua.1991 \\ Received: 19 Dec. 2016; Accepted: 15 Mar. 2017 \\ Viviane do Nascimento Bianchi; Marcos Roberto de Araujo Silva;
Marcus Augusto Lamim; Clovis Lucio da Silva;
Elizabete Campos de Lima* \\ Universidade Federal do ABC, (UFABC), Santo André, SP, Brasil \\ Centro de Ciências Naturais e Humanas \\ *Corresponding author: e-mail: elizabete.lima@ufabc.edu.br, \\ vivi.nbianchi@yahoo.com.br,marcos.araujo@ufabc.edu.br, \\ marcus.lamim@hotmail.com, clovis.silva@ufabc.edu.br
}

\begin{abstract}
Estrogens are emerging pollutants and traditional sewage treatments unable to remove them. They are harmful to human health and to the environment. It is therefore important to evaluate the presence and concentration of estrogens in water bodies and environmental matrices. This work presents the development and application of a methodology for the determination of E1, E3, EE2 and E2 in surface waters using solid phase extraction with molecular imprinting polymers (MISPE) followed by identification and quantification by HPLC-DAD. Acetonitrile and water deionized acidified with phosphoric acid pH $3(1: 1, \mathrm{v} / \mathrm{v})$, a flow rate of $1.0 \mathrm{ml} \mathrm{min}^{-1}$, at $40^{\circ} \mathrm{C}$ and an injection volume of $5 \mu \mathrm{L}$. The method was validated according to the protocol ICH Q2R. Reproducibility and repeatability tests resulted in a smaller variation coefficient of $10 \%$; the calibration curves in the concentration ranged from 1 to $20 \mathrm{mg} \mathrm{L}^{-1}$, with return linearity values greater than 0.99 . The limits of detection and quantification were less than $1 \mathrm{mg} \mathrm{L}^{-1}$ and the method was satisfactory for specificity and selectivity tests using caffeine, which is often found in water bodies receiving effluent, and DES, an estrogen used in the treatment of prostate cancer. Selected samples underwent cleanup and pre-concentration treatments using solid phase extraction with commercial phase (C18) and molecularly imprinted polymers (MISPE). The analysis of MISPE extracts indicate that it is possible to obtain results with greater sensitivity and precision for analyses of complex environmental matrices, demonstrating that the developed method can be applied in complex environmental matrices.
\end{abstract}

Keywords: emerging pollutants, endocrine disruptors, environmental matrices.

\section{Extração em fase sólida utilizando polímeros de impressão molecular (MISPE) para a determinação de estrógenos em águas superficiais por HPLC}

\section{RESUMO}

Estrogênios são poluentes emergentes e os tratamentos de esgoto tradicionais não são capazes de removê-los. São prejudiciais à saúde humana e ao ambiente. Portanto, torna-se 
importante avaliar a presença e concentração dessas substâncias em corpos hídricos e matrizes ambientais. No presente trabalho, apresenta-se o desenvolvimento e aplicação de uma metodologia para a determinação de E1, E3, EE2, E2 em águas superficiais utilizando a extração em fase sólida com polímeros de impressão molecular (MISPE) seguida da identificação e quantificação via HPLC-DAD. A fase móvel empregada foi acetonitrila e água acidificada, com ácido fosfórico, $\mathrm{pH} 3,(1: 1, \mathrm{v} / \mathrm{v})$, vazão $1,0 \mathrm{~mL} \mathrm{~min}^{-1}, 40^{\circ} \mathrm{C}$, injeção $5 \mu \mathrm{L}$ e $\lambda=280 \mathrm{~nm}$. O método foi validado segundo o protocolo ICH Q2 R1. Testes de reprodutibilidade e repetibilidade resultaram em coeficientes de variância menores que $10 \%$, e as curvas de calibração na faixa de concentração de 1 a $20 \mathrm{mg} \mathrm{L}^{-1}$ retornaram valores de linearidade maiores que 0,99 . Os limites de detecção e quantificação ficaram abaixo de $1 \mathrm{mg} \mathrm{L}^{-1}$ e o método mostrou-se satisfatório para testes de especificidade e seletividade usando cafeína encontrada em corpos hídricos que recebem efluentes, e DES, estrogênio utilizado em tratamento de câncer de próstata. Amostras selecionadas foram submetidas a clean-up e pré-concentração utilizando extração em fase sólida com fase comercial $(\mathrm{C} 18)$ e polímeros de impressão molecular (MISPE). Os extratos MISPE analisados indicaram que é possível obter resultados com maior sensibilidade e precisão para análises de matrizes ambientais complexas; mostrando que o método desenvolvido pode ser aplicado em matrizes ambientais complexas.

Palavras-chave: disruptores endócrinos, matrizes ambientais, poluentes emergentes.

\section{INTRODUCTION}

Emerging pollutants are defined as compounds of varied origins - pharmaceuticals, illicit drugs, personal care products, industrial additives, among others - that can be found in environmental and biological matrices, which often not controlled by regulatory agencies although they may pose a potential risk to human health and the environment (Naidu et al. 2016). Potential risks to human health and the environment include dysfunctions in the endocrine and reproductive systems of humans and animals, miscarriages, metabolic disorders and incidence of malignant neoplasms, as well as the introduction of resistant bacteria (Noguera-Oviedo and Aga, 2016).

The contamination of water resources is currently one of the main environmental problems, and the concern with micropollutants, substances found in concentrations in the order of $\mu \mathrm{g} \mathrm{L}^{-1}$ and $n g \mathrm{~L}^{-1}$, has recently increased (Bila and Dezotti, 2007) because they are capable of seriously harming living beings, despite the low concentrations in which they are detected. Hormones stand out from the substances that can be classified as micropollutants. Due to their damaging effects on the environment, it is necessary to develop techniques that detect and extract these substances from the aquatic environment. The impacts triggered by these substances on the environment are considered a matter of global scope, and can be observed from microinvertebrates to large vertebrates (Reis Filho et al., 2006).

Sexual hormones, one of the various classes of hormones, have greater relevance in the study of the contamination of effluents. Sexual hormones can be classified into female sex hormones, called estrogens, male hormones, known as androgens and pregnancy hormones or progestogens (Naidu et al., 2016; Reis Filho et al., 2006).

Estrogens are a group of hormones with similar chemical structure and effects in the estrous cycle, capable of acting as endocrine disruptors. In the aquatic environment, the effects of these compounds are not completely understood; but some damages have been observed, such as feminization of fish (Van Donk et al., 2016) and changes in physiological and reproductive behavior, including damages caused by progesterone (Figure 1), which acts as a reproductive hormone (Chang et al., 2011; Wang et al., 2015). 
Estrogens can be produced naturally by the human body, such as $\beta$-Estradiol(E2), estrone (E1) and estriol (E3); or may be synthetic, such as 17 $\alpha$-Ethynylestradiol (EE2) and mestranol(MeEE2) (Reis Filho et al., 2006). Figure 1 shows the molecular structures of these compounds.

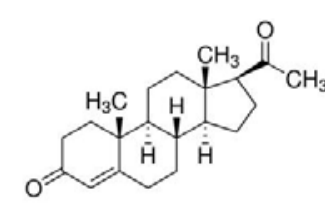

Progesterone

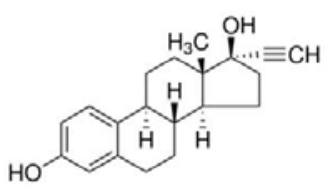

$17 \alpha$-ethinylestradiol

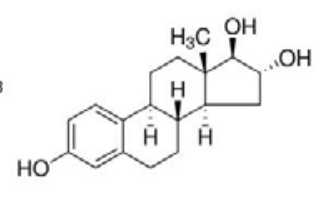

Estriol

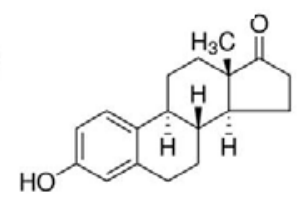

Estrone

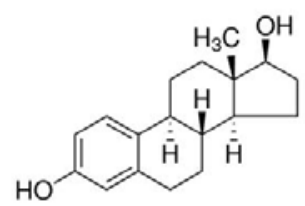

$\beta$-Estradiol

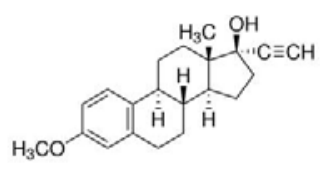

Mestranol

Figure 1. Molecular structure of the hormones progesterone (PROG), estriol (E3), $\beta$-estradiol (E2), 17 $\alpha$-ethinyl estradiol (EE2), estrone (E1) and mestranol (MeEE2).

The study by Liu and coworkers (Liu et al., 2015) estimated the natural estrogen excretion rates in some countries, and found Brazil to have the highest rate for E2 and E3 among countries as China, Korea, Japan, Iran, Turkey, Italy, Canada and the United States.

In order to better control the chemical compounds considered potentially emerging pollutants of interest in effluents, it is necessary to know the concentration of these compounds not only in natural water bodies but also in artificial water bodies and in water supply for human consumption (Nelson et al., 2010).

The most commonly used chemical instrumental analytical technique for determining hormones is high performance liquid chromatography (HPLC) coupled with different detection systems. In a review study, Gabet et al. (2007), Naidu et al. (2016), and Noguera-Ovedo and Aga (2016) gathered published papers from 1999 to 2007 highlighting information on hormone analysis in environmental matrices. In sample preparation prior to HPLC analysis, the most commonly used technique was filtration, solid phase extraction and online sample preparation. The most common techniques used for analysis were HPLC-MS, GC-MS and HPLC-MS / MS. Of the collected works, only one author used liquid chromatography with a DAD detector, resulting in limits of quantitation and detection higher than those obtained by HLC-MS. Therefore, the objective of the present work is to demonstrate the use of solid phase extraction with molecular imprinting polymers (MISPE) as an alternative clean-up and preconcentration methodology for the identification and quantification of estrogen hormones in surface water samples by HPLC-DAD. In sum, the main objective is to show the advantage of using a simple and sensitive preconcentration and clean-up technique and a more accessible detection system than an HPLC-MS system.

\section{MATERIAL AND METHODS}

A high-performance liquid chromatography (HPLC) method was developed for the determination of estrogens following the instructions provided by Snyder et al. (1997) and using as a starting point the study by Daniel and Lima (2014). An Agilent 1220 HPLC-DAD with 
automatic injector, a column furnace, OpenLAB revision A.01.05 data acquisition software, and a diode network detection system (DAD) were used to perform this work, with a Phenomenex kinetex C18 column $(30 \mathrm{~mm} \times 2,1 \mathrm{~mm} \times 5 \mu \mathrm{m})$. The parameters of the method were as follows: isocratic mode, mobile phase $50: 50 \mathrm{v} / \mathrm{v}$ acidified water with orthophosphoric acid (PA, LabSynth) (20 $\mu$ l of acid / L ultrapure water) and acetonitrile (HPLC grade, JT Baker), flow $1,0 \mathrm{~mL} \mathrm{~min}{ }^{-1}$, injection volume of $5 \mu \mathrm{L}$, temperature of $40^{\circ} \mathrm{C}$, reading in $\lambda=280 \mathrm{~nm}$, as described by Daniel and Lima (2014). In the same proportion of the mobile phase, stock solutions of estriol (E3), estrone (E1), 17 $\alpha$-ethinylestradiol (EE2), $\beta$-estradiol (E2), mestranol MeEE2) and progesterone (PROG) (all from Sigma Aldrich) were prepared in acetonitrile and water, in the concentration of $50 \mathrm{mg} \mathrm{L}^{-1}$. From these stock solutions, mixes of hormones in the concentration range of 1 to $20 \mathrm{mg} \mathrm{L}^{-1}$ were prepared.

The HPLC methodology developed as well as the solid phase extraction process were validated according to the protocol ICH Q2R1 (ICH, 2005). For this, tests were performed using a $10 \mathrm{mg} \mathrm{L}^{-1}$ hormone mix for repeatability and reproducibility and the respective coefficients of variance were calculated. A calibration curve was made with samples in the concentration range of 1 to $20 \mathrm{mg} \mathrm{L}^{-1}$, through which the linearity can be evaluated. In order to calculate the limits of detection and quantitation, the signal to noise ratio, $\mathrm{S} / \mathrm{N}$, was analyzed in a ratio of 3:1 for detection and 10:1 for quantification. To determine the specificity and selectivity, two compounds were used: caffeine (analytical standard in water, Agilent) and diethylstilbestrol (DES, Sigma Aldrich), adding $10 \mu \mathrm{L}$ of standard solution with a concentration of $50 \mathrm{mg} \mathrm{L}^{-1}$ to the mix previously used to provide repeatability and reproducibility.

\subsection{Extraction and preconcentration of hormones in surface water}

For extraction simulated samples with ultrapure water and simulated samples with tap water were prepared in triplicate by adding a standard solution of the mixed hormones, leading to a final concentration of $1 \mathrm{mg} \mathrm{L}^{-1}$. Duplicate samples of surface water collected in the subsurface region next to the discharge point of the Sewage Treatment Plant Pinheirinho, in the Alvarenga Arm of the Billings Dam. The water collected was kept in a thermal box for transporting and was then frozen until the day of the extraction procedure.

To begin, commercial C18 cartridges were washed with $3 \mathrm{~mL}$ of water, followed by $3 \mathrm{~mL}$ of methanol; $50 \mathrm{ml}$ of each sample was used for extraction. After passing this volume of sample through the cartridge, $3 \mathrm{~mL}$ of 50:50 v/v mixture of water and methanol was used to elute the retained compounds. The contents were eluted in test tubes and evaporated to dryness under nitrogen gas flow (99.9\% purity); then the samples were dissolved in $250 \mu \mathrm{l}$ of the mobile phase for analysis by the developed HPLC method. As an alternative, molecular imprinting polymer was used in the solid phase extraction of simulated samples with standard solutions.

The imprinting polymer was synthesized in a test tube using $2 \mathrm{~mL}$ of a $10 \mathrm{mg} \mathrm{L}^{-1}$ standard solution in acetonitrile of estriol, as template molecule (target analyte), $0.17 \mathrm{~mL}$ of methacrylic acid, $1.333 \mathrm{~mL}$ of ethylene glycol and $0.015 \mathrm{~g}$ of 2,2-azobisisobutyronitrile. The mixture was kept in a $60^{\circ} \mathrm{C}$ bath for 20 hours. The polymer was removed from the tube, oven dried at $40^{\circ} \mathrm{C}$ for 2 hours and triturated. The template molecule was removed by placing the polymer with $3 \mathrm{~mL}$ of methanol in ultrasonic bath for 5 minutes. After drying at room temperature, the polymer was placed in recycled extraction cartridges where the commercial stationary phase was replaced by the synthesized MISPE phase. The extraction procedure described for C18 cartridge was repeated for a simulated sample containing E3, E2, EE2 and E1 at the concentration of $1 \mathrm{mg} \mathrm{L}^{-1}$. The extracts obtained were analyzed comparatively (Figure 3 ). 


\section{RESULTS AND DISCUSSION}

\subsection{Development and optimization of the method}

The method was developed and optimized for the parameters of mobile phase proportion and temperature, until the best separation for the six hormones was obtained. The optimized mobile phase consisted of acetonitrile and acidified water in the ratio of 50:50 (v/v) and temperature of $40^{\circ} \mathrm{C}$, flow $1 \mathrm{~mL} \mathrm{~min}^{-1}$. To identify the corresponding peak for each analyte, $10 \mu \mathrm{L}$ of standard solution of each analyte was added at a time, and the mix was reanalyzed. Thus, by increasing the concentration of a compound, the intensity of its peak consequently increased so that the peak and its corresponding analyte were easily identified. To calculate the resolution obtained with the method under these conditions, a chromatogram (Figure 2) obtained for a mix of hormones containing E3, E2, EE2 and E1, mestranol (MeEE2) and progesterone (PROG) was used.

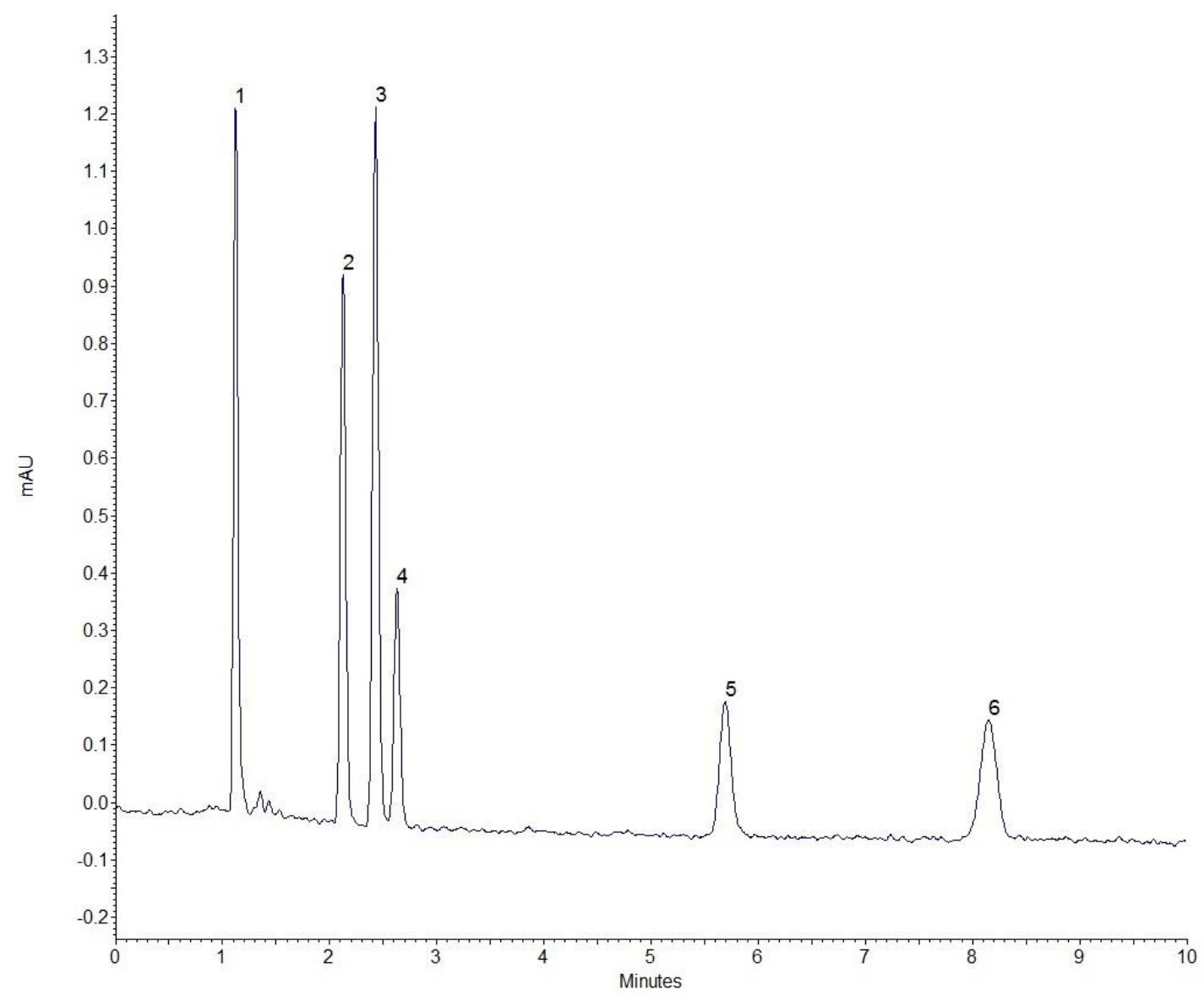

Figure 2. Amplified chromatogram of a mix at the concentration of $5 \mathrm{mg} \mathrm{L}^{-1}$ of the hormones studied. Analytical conditions: isocratic mode, mobile phase (50:50, v / v), deionized water acidified with orthophosphoric acid $\mathrm{pH} 3$, and HPLC grade acetonitrile, $1.0 \mathrm{~mL} \min -1$ flow, $5 \mu \mathrm{L}$ injection volume, $40^{\circ} \mathrm{C}, \lambda=280 \mathrm{~nm}$. The peaks refer to (1) E3, (2) E2, (3) EE2, (4) E1, (5) PROG, (6) MeEE2.

The obtained peaks had very good resolution values, i.e., resolution over 2 for all pairs of peaks; that is desirable when it comes to method development, except for the critical pair, peaks 3 and 4, i.e., EE2 / E1, presenting a value greater than 1.5, compatible for bands of similar sizes. Table 1 shows the resolution values obtained for each pair of analytes according to the chromatogram of Figure 2. 
The constant temperature at $40^{\circ} \mathrm{C}$ contributed to the good resolution, because, due to the increase in temperature the retention factor also increases and consequently the resolution improves (Snyder et al., 1997).

Table 1. Resolution obtained for the analytes studied in the method developed.

\begin{tabular}{lc}
\hline \multicolumn{1}{c}{ Pairs of peaks } & Resolution \\
\hline Estriol / $\beta$-estradiol(E3/E1) & 7.25 \\
$\beta$-estradiol / 17 $\alpha$-etinilestradiol (E2/EE2) & 2.20 \\
17 $\alpha$-ethinylestradiol / Estrone (EE2/E1) & 1.64 \\
Estrone / Progesterona (E1/PROG) & 15.84 \\
Progesterone / Mestranol (PROG/MeEE2) & 8.11 \\
\hline
\end{tabular}

\subsection{Validation of the method}

From the chromatogram of the $5 \mathrm{mg} \mathrm{L}^{-1}$ hormone mix with all peaks duly identified, the detection and quantification limits were calculated following the signal-to-noise ratio of 3:1 and 10: 1, respectively, for each analyte. The values found are shown in Table 2.

Table 2. Detection Limit Values and Quantification Limits for the hormones studied.

\begin{tabular}{lcc}
\hline Analyte & Detection Limit $\left(\mathrm{mg} \mathrm{L}^{-1}\right)$ & Quantification Limit $\left(\mathrm{mg} \mathrm{L}^{1}\right)$ \\
\hline Estriol (E3) & 0.12 & 0.41 \\
$\beta$-estradiol (E2) & 0.16 & 0.54 \\
17 $\alpha$-ethinylestradiol (EE2) & 0.12 & 0.41 \\
Estrone (E1) & 0.39 & 1.32 \\
Progesterone (PROG) & 0.83 & 2.77 \\
Mestranol (MeEE2) & 0.94 & 3.13 \\
\hline
\end{tabular}

The values found were satisfactory considering that they were micro-pollutants. However, these values are still higher than those obtained in studies using mass spectrometer detector (Gabet et al., 2007). It is therefore suggested that the use of a sample preconcentration step would be ideal.

Using a $10 \mathrm{mg} \mathrm{L}^{-1}$ hormone mix, the precision of the method was evaluated through intra-assay and inter-assay coefficients of variance. The values obtained are shown in Table 3 . The values were mostly below $2 \%$, with the exception of E1. According to Snyder et al. (1997), the accuracy should be close to $2 \%$. The ICH Q2R1 protocol does not specify the limit of the coefficient of variance.

Another parameter evaluated in the validation is the accuracy, that is, the proximity of the measured values to the actual values. For that, three concentrations of the extension of the calibration curve were used, in triplicate. The values are presented in Annex A. Accuracy values should be up to $2 \%$ or be between $10 \%$ and $20 \%$ when dealing with traits according to Snyder et al. (1997). Thus, the values are satisfactory for PROG, EE2 and E2. For the other hormones, the values are lower than $20 \%$; however, considering the concentration of $20 \mathrm{mg} \mathrm{L}^{-1}$, the accuracy is high, especially for E3 and E1. A possible contributing factor to increase this error is the standard solution used. There is no ready standard solution for these hormones, and it is necessary to prepare them from the solid compound. Therefore, the stock solution is susceptible to errors in weighing and dissolving the hormones. 
Table 3. Values of the coefficient of variance for intra- and interassay of the method developed for the six hormones.

\begin{tabular}{lcc}
\hline Analito & Intra-assay & Inter-assay \\
\hline Estriol & $1.55 \%$ & $4.31 \%$ \\
$\beta$-estradiol & $1.22 \%$ & $1.60 \%$ \\
$17 \alpha$-ethinylestradiol & $0.72 \%$ & $0.80 \%$ \\
Estrone & $2.72 \%$ & $3.23 \%$ \\
Progesterone & $1.32 \%$ & $1.97 \%$ \\
Mestranol & $1.61 \%$ & $2.67 \%$ \\
\hline
\end{tabular}

The calibration curve was made in the range of 1 to $20 \mathrm{mg} \mathrm{L}^{-1}$ concentration, with five points. The linearity obtained with the curves was very satisfactory, presenting $\mathrm{r}^{2}$ values greater than 0.999 . In order to verify the specificity of the method, the compound diethylstilbestrol (DES), a synthetic estrogen, was added to the standard mix.

In addition to DES, caffeine was added to the sample because it is a compound commonly found in effluent samples. The separation was effective, demonstrating the specificity of the method. The separation of the eight compounds applying the developed method can be observed in Figure 3.

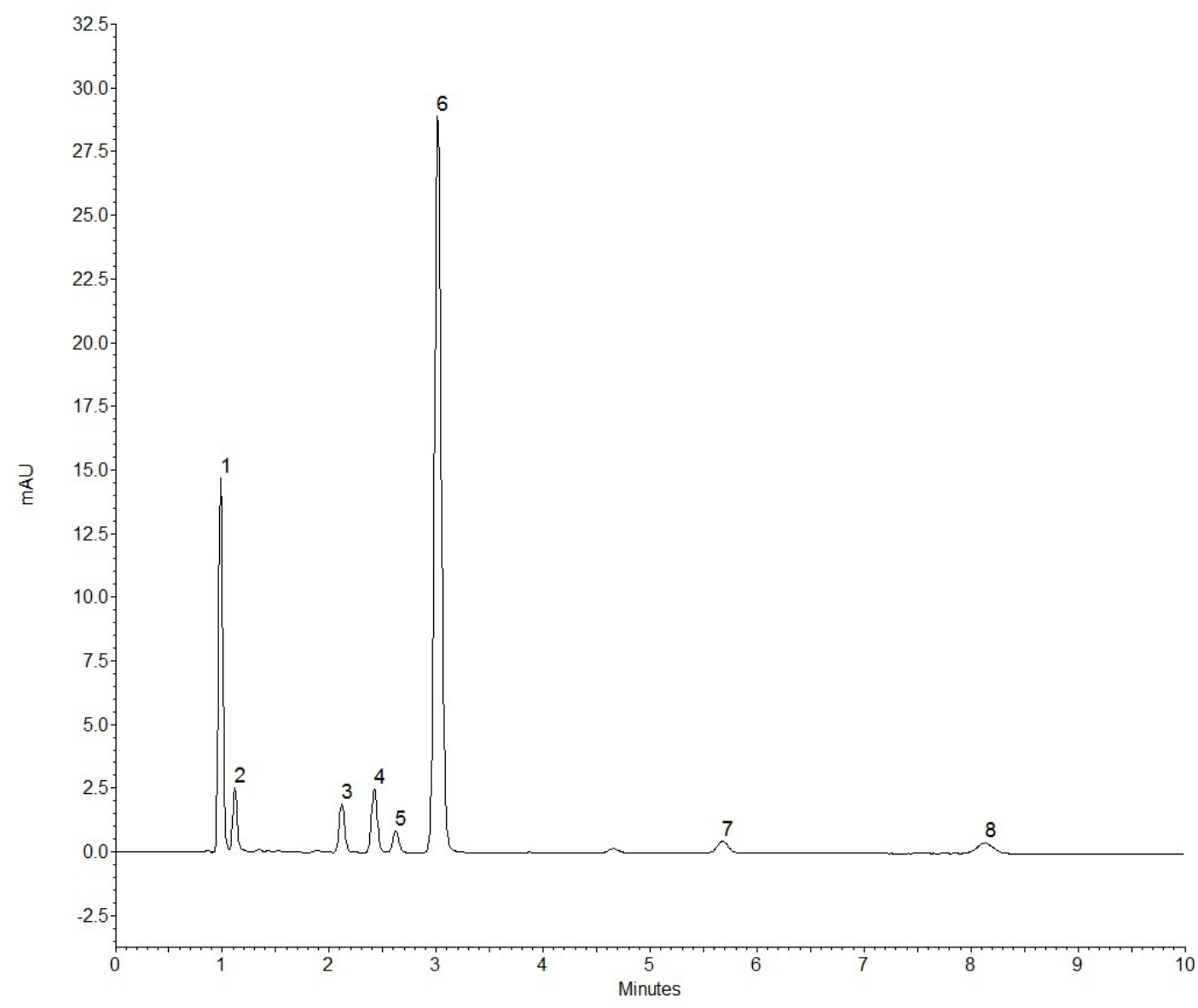

Figure 3. Chromatogram obtained after the addition of DES and caffeine, showing the separation for (1) caffeine, (2) E3, (3) E2, (4) EE2, (5) E1, (6) DES, (7) PROG and 8) MeEE2. Analytical conditions: isocratic mode, mobile phase $(50: 50, \mathrm{v} / \mathrm{v})$ deionized water acidified with orthophosphoric acid $\mathrm{pH} \mathrm{3}$, and HPLC grade acetonitrile, $1.0 \mathrm{~mL} \mathrm{~min}^{-1}$ flow, $5 \mu \mathrm{L}$ injection volume, $40^{\circ} \mathrm{C}, \lambda=280 \mathrm{~nm}$. 


\subsection{Simulated Sample Analysis and real Sample}

The simulated and collected samples submitted to the solid phase extraction (SPE) with commercial cartridge were analyzed using the validated method. However, no analyte could be identified. However, the fact that the extracts analyzed by the validated methodology did not result in a chromatogram with peaks suggests the $\mathrm{C} 18$ commercial phases do not promote clean-up and preconcentration with adequate sensitivity for the determination of trace levels of hormones. However, replacing the commercial phase $\mathrm{C} 18$ by the molecular imprinting polymer synthesized with estriol (E3) as template and applying the same procedure of the extraction, the analysis returned satisfactory results, as shown in Figure 4.

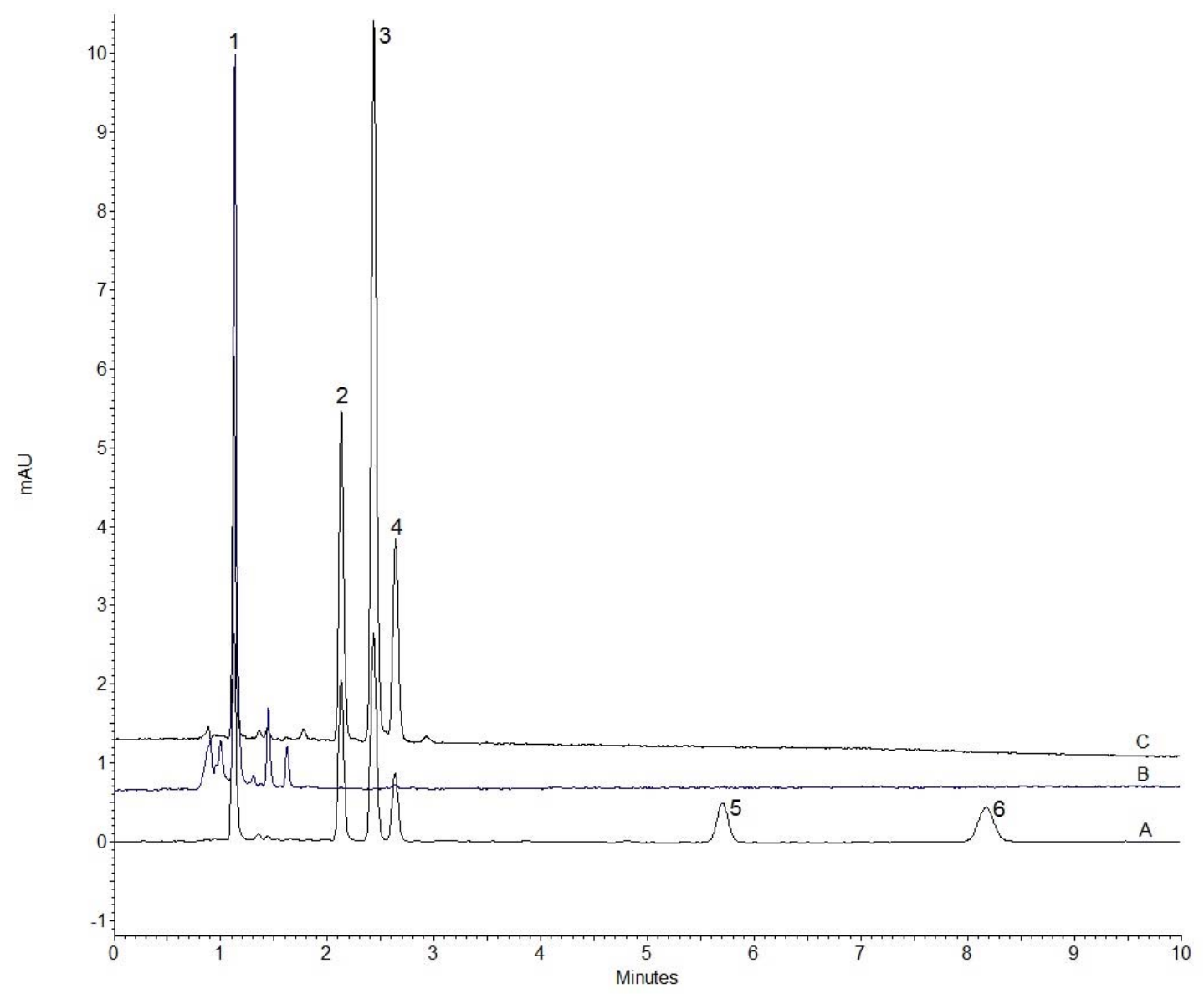

Figure 4. Chromatograms obtained for sample of estrogen hormone mix (1) E3, (2) E2, (3) EE2, (4) E1, (5) PROG, (6) MeEE2: (A) B) chromatogram of the SPE extract using commercial C18 cartridge and $(C)$ extract chromatogram using SPE with MIP phase synthesized in the laboratory. Analytical conditions: isocratic mode, mobile phase (50:50, v/ v) deionized water acidified with orthophosphoric acid $\mathrm{pH} 3$, and HPLC grade acetonitrile, $1.0 \mathrm{~mL} \mathrm{m^{-1 }}$ flow, $5 \mu \mathrm{L}$ injection, $40^{\circ} \mathrm{C}, \Lambda=280 \mathrm{~nm}$.

Because of the similar molecular structure, the estrogen hormones present in the simulated sample, in this case, estriol, $\beta$-estradiol, $17 \alpha$-ethinyl estradiol and estrone, were expected to be retained at the active sites and extracted from the sample. The results were compatible with the expected results, since in the simulated sample analysis the four hormones were identified. Therefore, the method proved to be effective in the proposed application and it was possible to highlight the potential of the molecular imprinting polymers for clean-up and pre-concentration of the analytes in complex matrices like the environmental samples. The sample of the Pinheirinho station analyzed showed the presence of $17 \alpha$-ethinylestradiol (EE2); but it was only 
possible to perform the spectral identification of the same using the spectrum analysis feature that the Agilent 1220 HPLC with the DAD detector allows, because the EE2 peak has a height and area below the limit of detection obtained by the validated methodology.

As can be observed, MIPs play an important role in the preparation of samples for chromatographic analysis, as shown by the work of Castillo-García et al. (2016) in which a survey from 2011 to 2015 found that $17.2 \%$ of the published papers used MIPs for sample preparation. This demonstrates the versatility, applicability and importance of these materials in preparation of samples for chromatographic analysis.

\section{CONCLUSIONS}

The developed method is simple, resulted in excellent resolution for the separation of the six hormones studied, with excellent linearity in the range of 1 to $20 \mathrm{mg} \mathrm{L}^{-1}$. The values for coefficient of variance and accuracy were good and the method was specific with very good separation of eight compounds, which are these hormones and the interfering caffeine and DES (diethylstilbestrol). The limits of detection and quantitation are in the order of microgram per liter, thus it may be better to analyze samples after preparation techniques that concentrate the analytes. An alternative is the application of solid phase extraction with molecular imprinting polymers, which seemed to be effective in applying the developed and validated method. Future studies involve the synthesis, characterization and application of these polymers and the method and afterwards for the inclusion of more environmentally important hormones as well as other classes of endocrine disruptors. It is also necessary to improve the sensitivity of the synthesized MISPE phases to minimize matrix effects.

\section{ACKNOWLEDGEMENTS}

We thank FAPESP Process 2013/12569-8 for the research support.

\section{REFERENCES}

BILA, D. M.; DEZOTTI, M. Desreguladores endócrinos no meio ambiente: efeitos e consequências. Química Nova, v. 30, p. 651-666, 2007. http://dx.doi.org/10.1590/ S0100-40422007000300027

CASTILlO-GARCÍA, M. L.; AGUILAR-CABALLOS, A.; GÓMEZ-HENZ. Nanomaterials as tools in chromatographic methods. Trends in Analytical Chemistry, v. 82, p. $385-$ 393, 2016. http://dx.doi.org/10.1016/j.trac.2016.06.019

CHANG, H.; WAN, Y.; WU, S.; FAN, Z.; HU, J. Occurrence of androgens and progestogens in wastewater treatment plants and receiving river Waters: Comparison to estrogens. Water Research, v. 45, p. 732-740, 2011. http://dx.doi.org/10.1016/j. jhazmat.2009.06.135

DANIEL, M. da S.; LIMA, E. C. de. Determinação simultânea de estriol, $\beta$-estradiol, $17 \alpha$-etinilestradiol e estrona empregando-se extração em fase sólida (SPE) e cromatografia líquida de alta eficiência (HPLC). Revista Ambiente \& Água, v. 9, p. 688695, 2014. http://dx.doi.org/10.4136/ambi-agua.1346

GABET, V.; MIÈGE, C.; BADOS, P.; COQUERY, M. Analysis of estrogens in environmental matrices. Trends is Analytical Chemistry, v. 26, n. 11, p. 1113-1131, 2007. http://dx.doi.org/10.1016/j.trac.2007.10.003 
INTERNATIONAL CONFERENCE ON HARMONISATION OF TECHNICAL REQUIREMENTS FOR REGISTRATION OF PHARMACEUTICALS FOR HUMAN USE (ICH). Validation of analytical procedures: text and methodology Q2(R1). Ottawa, 2005.

LIU, Z.; LU, G.; HUA, Y.; DANG, Z. Estimated human excretion rates of natural estrogens calculated from their concentrations in raw municipal wastewater and its application. Environmental Science and Pollution Research, v. 22, p. 9554 - 9562, 2015. http://dx.doi.org/10.1021/es035342u

NAIDU, R.; ESPANA, V.; LIU, Y.; JOYTTISHNA, J. Emerging contaminants in the environment: Risk-based analysis for better management. Chemosphere, v. 154, p. 350357, 2016. http://dx.doi.org/10.1016/j.chemosphere.2016.03.068

NELSON, E. D.; DO, H.; LEWIS, R. S.; CARR, S. A. Diurnal variability of pharmaceutical, personal care product, estrogen and alkylphenol concentrations in effluent from a tertiary wastewater treatment facility. Environmental Science \& Technology, v. 45, p. 1228 1234, 2010. http://dx.doi.org/10.1021/es102452f

NOGUERA-OVIEDO, K.; AGA, D. S. Lessons learned from more than two decades of research on emerging contaminants in the environment. Journal of Hazardous Materials, v. 316, p. 242-251, 2016. http://dx.doi.org/10.1016/j.jhazmat.2016.04.058

REIS FILHO, W. R.; ARAUJO J. C.; VIEIRA, E. M. Hormônios sexuais estrógenos: contaminantes bioativos. Química Nova, v. 29, p. 817-822, 2006. http://dx.doi.org/10.1590/S0100-40422006000400032

SNYDER, L. R.; KIRKLAND, J. J.; GLAJCH, J. L. Practical HPLC Method Development. $2^{\text {nd }}$ Ed. New Jersey: Wiley, 1997. p. 22-92

VAN DONK, E.; PEACOR, S.; GROSSER, K.; DOMIS, L. N. De S.; LÜRLING, M. Pharmaceuticals May Disrupt Natural Chemical Information Flows and Species Interactions in Aquatic Systems: Ideas and Perspectives on a Hidden Global Change. Reviews of Environmental Contamination and Toxicology, v. 238, p. 91-105, 2016. http://dx.doi.org/10.1007/978-3-319-30791-6

WANG, Y.; WANG, Q.; HU, L.; LU, G.; LI, Y. Occurrence of estrogens in water, sediment and biota and their ecological risk in Northern Taihu Lake in China. Environmental Geochemistry Health, v. 37, p. 147-156, 2015. http://dx.doi.org/10.1007/s10653-0149637-0 


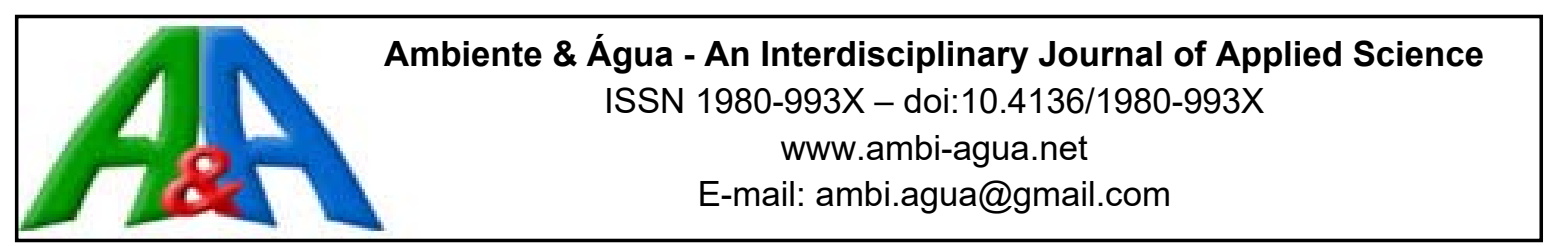

\title{
Effects of global climate change on chlorophyll-a concentrations in a tropical aquatic system during a cyanobacterial bloom: a microcosm study
}

doi:10.4136/ambi-agua.2014

Received: 11 Oct. 2016; Accepted: 23 Feb. 2017

\author{
Meirielle Euripa Pádua de Moura ${ }^{1}$; Lorraine dos Santos Rocha ${ }^{2}$; \\ João Carlos Nabout ${ }^{2 *}$ \\ Universidade Estadual de Goiás (UEG), Anápolis, GO, Brasil \\ ${ }^{1}$ Departamento de Recursos Naturais do Cerrado \\ ${ }^{2}$ Departamento de Ciências Biológicas \\ *Autor correspondente: e-mail: joao.nabout@ueg.br, \\ meirielle-euripa@hotmail.com, santoslor18@gmail.com
}

\begin{abstract}
Recent studies have investigated the impact of climate change on aquatic environments, and Chlorophyll- $a$ (Chl- $a$ ) concentration is a quick and reliable variable for monitoring such changes. This study evaluated the impact of rainfall frequency as a diluting agent and the effect of increased temperature on Chl- $a$ concentrations in eutrophic environments during a bloom of cyanobacteria. This was based on the hypothesis that the concentration of Chl- $a$ will be higher in treatments in which the rainfall frequency is not homogeneous and that warmer temperatures predicted due to climate change should favor higher concentrations of Chl-a. The experiment was designed to investigate three factors: temperature, precipitation and time. Temperature was tested with two treatment levels $\left(22^{\circ} \mathrm{C}\right.$ and the future temperature of $\left.25^{\circ} \mathrm{C}\right)$. Precipitation was tested with four treatments (no precipitation, a homogeneous precipitation pattern, and two types of concentrated precipitation patterns). Experiments were run for 15 days, and Chl- $a$ concentration was measured every five days in each of the temperature and precipitation treatments. The water used in the microcosms was collected from a eutrophic lake located in Central Brazil during a bloom of filamentous cyanobacteria (Geilterinema amphibium). Chl-a levels were high in all treatments. The higher temperature treatment showed increased Chl- $a$ concentration $(\mathrm{F}=10.343 ; P=0.002)$; however, the extreme precipitation events did not significantly influence Chl- $a$ concentrations $(\mathrm{F}=1.198 ; P=0.326)$. Therefore, the study demonstrates that future climatic conditions (projected to 2100), such as elevated temperatures, may affect the primary productivity of aquatic environments in tropical aquatic systems.
\end{abstract}

Keywords: extreme events, Geitlerinema amphibium, primary productivity, temperature.

\section{Efeito das mudanças climáticas globais na concentração de Chlorofila-a em um Sistema aquático tropical durante uma floração de cianobactéria: Um estudo em microcosmo}

\section{RESUMO}

Estudos recentes têm investigado o impacto das mudanças climáticas em ambientes aquáticos, além disso a Clorofila-a (Clo-a) é uma variável de rápida avaliação e confiável para 
o monitoramento de ambientes aquáticos. O objetivo do presente estudo foi avaliar o impacto da frequência da precipitação e do aumento da temperature na concentração de Clo-a em um ambiente aquático eutrófico durante um período de floração de cianobactéria. As hipóteses para o presente trabalho: i) A concentração de Clo-a será maior em tratamentos em que a frequencia de precipitação não é homogênea, e ii) Temperaturas mais quentes devem promover aumento na concentração de Clo-a. Foi utilizado um desenho experimental com três fatores: Precipitação, temperature e tempo. A temperature foi avaliada em dois tratamentos $\left(22^{\circ} \mathrm{C}\right.$ e a temperatura futura de $25^{\circ} \mathrm{C}$ ). A precipitação foi avaliada em quatro tratamentos (ausência de precipitação, precipitação homogênea, e dois tipos precipitação concentrada). O experimento foi desenvolvido por 15 dias e a concentração de Clo-a foi mensurada a cada cinco dias para cada tratamento. Os níveis de Clo-a foram elevados em todos tratamentos, além disso, a concentração de Clo-a foi maior em tratamentos mais aquecidos (simulando cenário futuro) $(\mathrm{F}=10.343 ; P=0.002)$; entretanto, os eventos extremos de precipitação não demonstraram influência na concentração de Clo-a $(\mathrm{F}=1.198 ; P=0.326)$. Portanto, o presente trabalho demonstrou que as condições climáticas futuras (projetadas para 2100), como o aumento da temperatura, devem afetar a produtividade primária de ambientes aquáticos.

Palavras-chaves: eventos extremos, Geitlerinema amphibium, produtividade primária, temperatura.

\section{INTRODUCTION}

The study of global climate change has attracted interest from the scientific community since the 1970s (e.g., Kopec, 1971). However, it was not until the beginning of the twenty-first century that scientific publications concerning climate change increased significantly (see Nabout et al., 2012a). Various scenarios have been proposed concerning the negative effects of climate change on human and natural systems, including warming and ocean acidification (Christensen et al., 2006; Doney et al., 2009), biodiversity loss (Hoegh-Guldberg et al., 2007), loss of arable land (Nabout et al., 2012b), and changes to disease vector distributions (Paz, 2015).

In aquatic environments, the major factors impacted by increased air temperatures are changes in precipitation and wind (Nickus et al., 2010; Roland et al., 2012). These factors can cause physical changes to the environment through stratification (Jeznach and Tobiason, 2015) or turbidity (Meerhoff et al., 2007), and chemical changes such as oxygen concentration (Gordon et al., 2004; Jeppesen et al., 2013) or nutrient cycling (Lecerf et al., 2007), and biological changes in the phenology of species (Daufresne et al., 2009). Experimental approaches have been used to evaluate the effect of climate change in aquatic environments. These experiments typically focus on the effects of the increased temperature expected in future scenarios (Jeppesen et al., 2010; Yvon-Durocher et al., 2010; Roland et al., 2012). However, recent studies have investigated other elements affecting aquatic ecosystems as well as their combined effects, such as the interaction between warming, drying, and acidification on consumers and planktonic producers (Christensen et al., 2006), the effects of climate change on water levels compounded with stratification (Berger et al., 2010), the effect of light and $\mathrm{CO}_{2}$ enrichment on nutrient concentrations (Andersen et al., 2005), and the effect of temperature and predation on phytoplankton community (He et al. 2015).

In addition to changes in temperature, the Intergovernmental Panel on Climate Change (IPCC, 2014) predicts that tropical ecosystems will experience altered hydrological cycles with an increased frequency of extreme events such as concentrated precipitation (IPCC, 2014). Extreme rainfall in some river basins can lead to increased flooding risk (Rockström et al., 2014), changes in runoff (Roland et al., 2012), and changes in Chl- $a$ concentrations (Belnap et al., 2005). Thus, extreme rainfall events can change dilutive effects and reduce zooplankton 
predation, promoting an increase in Chl- $a$ concentrations (see Dolan et al., 2000 for dilution effects). In addition to altered aquatic and peripheral communities, climate change can also compromise water resource quality (Codd, 2000; IPCC, 2014). Certain types of climate change can cause eutrophication that stimulates the growth of cyanobacteria facilitating the concentration of toxins (Reichwaldt and Ghadouani, 2012). Thus, studies that investigate the combined effect of climate change phenomena, such as elevated temperature and precipitation, are necessary in order to understand the changing conditions of tropical aquatic environments.

Experimental studies are therefore important tools to test the effects of climate change in aquatic ecosystem (see for example Li et al., 2016; 2017; Short et al., 2016). In fact, the majority of these experimental studies have been developed in temperate regions, and thus offer little insight about the impact of climate change in tropical aquatic ecosystems (see Roland et al., 2012). Nonetheless, experimental and whole lakes studies have shown that climate change (e.g. extreme events and warming) can affect aquatic tropical environments by modifying their geochemistry (Roland et al., 2012), altering species composition and functional groups (e.g. Costa et al., 2015), or increasing cyanobacterial dominance (Kosten et al., 2012). In fact, toxic Cyanophyceae has occurred in tropical environments (Mowe et al., 2015a).

Some studies have not found any relationship between temperature change and Chl- $a$ concentrations (see Moss et al., 2003; Feuchtmayr et al., 2009). Due to the diversity of phytoplankton species, there are many optimum temperature ranges for growth (Seip and Reynolds, 1995), thus elevated temperatures may not change the size of the community, but rather species composition (Moss et al., 2003 Van de Bund et al., 2004). Other studies, however, have found associations between increased temperature and frequency of cyanobacterial bloom phenomena (Reynolds, 2006; Jeppesen et al., 2009; Tundisi et al., 2015; Mowe et al., 2015b) and increased gross primary production (Yvon-Durocher et al., 2015).

This study evaluated the impact of rainfall frequency and increased temperature on chlorophyll- $a$ concentrations in eutrophic environments during a bloom of cyanobacteria. This was based on the expectations that: i) the intensity of rainfall in a short period of time would increase chlorophyll- $a$ concentrations in the treatments with the most homogeneous precipitation conditions, and ii) the warmer temperatures predicted due to climate change should favor higher concentrations of chlorophyll- $a$.

\section{MATERIAL AND METHODS}

\subsection{Experimental design}

The experimental design investigated three factors: temperature, precipitation, and time. There were two temperature levels (current and future) and four levels of precipitation (no precipitation, a homogeneous precipitation pattern, and two types of concentrated precipitation patterns). Experiments were run for 15 days, and Chl- $a$ concentration was measured every five days in each temperature and precipitation treatment.

Experiments were performed in microcosms. We prepared 40 beaker microcosms, each with a total volume of $2 \mathrm{~L}$. Each beaker received $1 \mathrm{~L}$ of water initially from an artificiallandscape with a eutrophic lake located at the Universidade Estadual de Goiás (City of Anápolis, Central Brazil). Samples were gathered from the lake during a bloom of the filamentous cyanobacteria, Geitlerinema amphibium (Figure 1 in supplementary material S1), in May 2015. Other organisms, such as other species of algae or zooplankton adhering to the mass of Geitlerinema amphibium were not removed. However, the analysis of algae species presented in this lake indicated that $99 \%$ of the total biomass was represented by G. amphibium. Thus, the Chl-a analysis used in this study was represented exclusively by this species.

Rev. Ambient. Água vol. 12 n. 3 Taubaté - May / Jun. 2017 


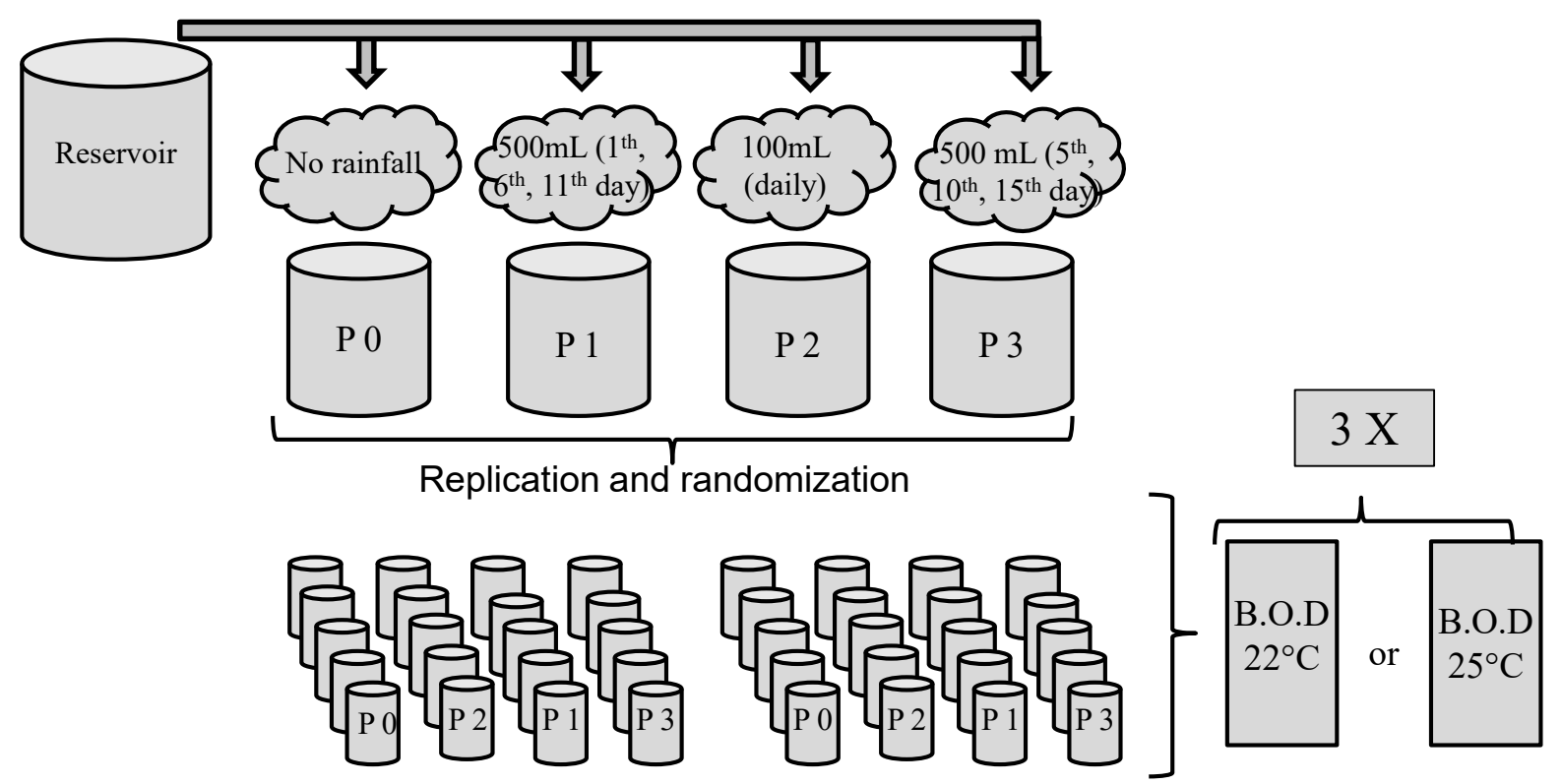

Figure 1. Schematic representation of the experiment. Water from a lake was used to fill the microcosms. The microcosm P0 received no distilled water, P1 received $500 \mathrm{~mL}$ of distilled water on the first day and every five days following, $\mathrm{P} 2$ received $100 \mathrm{~mL}$ of distilled water daily, and P3 received $500 \mathrm{~mL}$ of distilled water on the fifth day and every five days following. The experiments were placed in BOD incubators, simulating current $\left(22^{\circ} \mathrm{C}\right)$ and future $\left(25^{\circ} \mathrm{C}\right)$ temperatures. There were 20 replicates of each treatment of temperature and 10 replicates of each treatment of precipitation. The experiment was conducted for 15 days with samples collected every five days for Chlorophyll- $a$ measurements.

We obtained climate data from the EcoClimate database (Lima-Ribeiro et al., 2015) for neotropical regions, which includes current and predicted future climate conditions under different scenarios and global circulation models. We defined temperature and precipitation values using the CCSM model (Community Climate System Model) RCP 4.5 (obtained through the EcoClimate database; Lima-Ribeiro et al., 2015). The EcoClimate database has 19 climatic variables (derived from temperature and precipitation) for worldwide, containing current and future climate data. We used a climate scenario considered to have an intermediate level of greenhouse gas emissions, projected for the year 2100. This climate scenario has been used often in global climate change research (Pendergrass and Hartmann, 2012). The annual mean temperature for the Cerrado Biome is $23.7^{\circ} \mathrm{C}$, and the future climate scenarios estimate an increase of $3^{\circ} \mathrm{C}$ (according to the CCSM model, available in the EcoClimate database). According CCSM model the annual rainfall for the Cerrado Biome is $1170 \mathrm{~L}$ for the current climate scenario, and 1096L in future scenarios. Although this is only a small change in rainfall, the climate models suggest an increase of extreme events, such as, concentrated rainfall in a short period of time, and long periods of drought (see Marengo et al., 2009). Thus, based on this expectation, we simulated the concentrated precipitation as an extreme event. For this, the experiments received the same amount of water, but the variance was different. Thus, the concentrated treatments presented higher variance. The variance was estimated based on the change of precipitation in future scenarios, according to the CCSM model.

We used the temperature and precipitation values of the region where the lake samples were collected (City of Anápolis, Central Brazil), and selected two climatic variables: annual mean temperature and the precipitation of the wettest quarter corresponding to our study period. These two variables were obtained for the current and future climate scenarios. The current temperature was set at $22^{\circ} \mathrm{C}$ and the future temperature at $25^{\circ} \mathrm{C}$. For precipitation, we simulated three conditions of rainfall (two concentrated and one homogeneous) and one control, according 
to projected future scenarios (Marengo et al., 2009) Thus, for the same amount of precipitation we simulate extreme and homogeneous conditions.

Considering the climatic data of the study region, we developed the following experimental design. We simulated two temperature conditions in the microcosms; one treatment level corresponded to the current temperature of $22^{\circ} \mathrm{C}$ and the other corresponded to the future temperature of $25^{\circ} \mathrm{C}$ predicted according to CCSM RCP4.5, projected to 2100 . To simulate the effect of different rainfall patterns, distilled water was added to the microcosms. There were three precipitation scenarios, and a control ( $\mathrm{P} 0)$ with no precipitation. In the first treatment $(\mathrm{P} 1)$, $500 \mathrm{~mL}$ of distilled water was added to the microcosms every five days, beginning on the first day of the experiment, in order to simulate an extreme precipitation event. In the second treatment (P2), $100 \mathrm{~mL}$ of distilled water was added daily to the microcosms in order to simulate frequent rainfall. In the third treatment (P3), $500 \mathrm{~mL}$ of distilled water was added every five days beginning on the fifth day of the experiment. Treatments P1 and P3 simulated similar extreme events but with different start dates during the experiment (Figure 1).

We distributed the precipitation treatments in two BOD incubators with a photoperiod of $12 \mathrm{~h} / 12 \mathrm{~h}$ set at the two different temperatures, $22^{\circ} \mathrm{C}$ and $25^{\circ} \mathrm{C}$. The distribution of beakers in BOD incubators was determined randomly. Thus, each temperature treatment had 20 replicas, and each precipitation treatment had 10 replicas.

Before the experiment, we developed two series of pilot experiments, in which it was possible to determine the temporal interval of the experiment (degradation of chlorophyll-a occurred at more than 15 days), time among water adding, the method for adding water, time of light exposure, and other factors.

\subsection{Chlorophyll-a analysis}

The water from each microcosm was filtered through $47 \mathrm{~mm}$ glass fiber filters (Milipore $0.45 \mathrm{~m}$ ) prior to chlorophyll- $a$ analysis. Filters were placed in foil envelopes, stored in the dark, and kept in a refrigerator until processing. Quantitative analysis of chlorophyll- $a$ was performed after acetone extraction according to the method in Golterman et al. (1978). Chl- $a$ concentrations were determined once for each beaker using a volume of $190 \mathrm{~mL}$.

\subsection{Data analysis}

The difference between treatments was determined using a factorial analysis of variance (ANOVA, $\mathrm{P}<0.05$ ) for repeated measures (Zar, 2010). Chl- $a$ concentration was the dependent variable, with precipitation (at 3 levels) temperature (at 2 levels) and time as factors. Time was the total number of days in the experiment. The variables were $\log x+1$ transformed to meet the assumptions of normality and homogeneity of variances. To verify the assumptions, we used the Kolmogorov-Smirnov (KS) test for normality and the Levene homogeneity tests for homogeneity of variance.

\section{RESULTS AND DISCUSSION}

Chlorophyll- $a$ concentrations presented high values in all treatments (see descriptive statistic in Table 1); moreover, the value varied between treatments. Thus, after transforming the data, the assumption of normality required for ANOVA was supported, for Chl- $a$ on the $5^{\text {th }}$ day $(\mathrm{d}=0.18 ; \mathrm{P}=0.15), 10^{\text {th }}$ day $(\mathrm{d}=0.15 ; \mathrm{P}=0.20)$ and $15^{\text {th }}$ day $(\mathrm{d}=0.14 ; P=0.20)$. The assumption of homogeneity of variance was also supported for Chl- $a$ on the $5^{\text {th }}$ day $(\mathrm{F}=3.8$; $\mathrm{P}=0.06), 10^{\text {th }}$ day $(\mathrm{F}=1.1 ; \mathrm{P}=0.29)$ and $15^{\text {th }}$ day $(\mathrm{F}=0.07 ; \mathrm{P}=0.79)$. 
Table 1. Mean and standard deviation (SD) of Chlorophyll-a concentration $\left(\mu \mathrm{gL}^{-1}\right)$ registered in each treatment and levels in microcosm experiment.

\begin{tabular}{|c|c|c|c|c|c|c|c|}
\hline \multirow[t]{2}{*}{ Treatment } & \multirow[t]{2}{*}{ Levels } & \multicolumn{2}{|c|}{ 5th day } & \multicolumn{2}{|c|}{ 10th day } & \multicolumn{2}{|c|}{ 15th day } \\
\hline & & Mean & SD & Mean & SD & Mean & SD \\
\hline \multirow{3}{*}{ Temperature } & Current & 170.8 & 169.8 & 191.8 & 122.0 & 157.3 & 164.3 \\
\hline & Future & 179.9 & 117.6 & 223.1 & 161.2 & 706.5 & 1235.9 \\
\hline & $\mathrm{P} 1$ & 195.4 & 174.0 & 330.5 & 175.8 & 727.9 & 957.5 \\
\hline \multirow[t]{3}{*}{ Precipitation } & $\mathrm{P} 2$ & 152.5 & 48.2 & 144.0 & 86.3 & 235.8 & 308.8 \\
\hline & P3 & 240.4 & 213.4 & 178.9 & 70.7 & 624.4 & 1524.4 \\
\hline & P4 & 113.1 & 44.4 & 176.5 & 144.0 & 139.6 & 66.1 \\
\hline
\end{tabular}

Chl- $a$ concentrations varied significantly with temperature (Table 2; Figure 2). Increased temperature caused a significant increase in Chl- $a$ concentrations, but precipitation did not cause any significant difference in Chl- $a$ concentrations (Figure 3).

Table 2. Statistical significance of the treatment effects on Chlorophyll- $a$ concentration, considering the interaction of precipitation, temperature, and time, through repeated analysis of variance. Significant values are in bold $(P<0.05)$.

\begin{tabular}{lccc}
\hline & Degrees Freedom & $\mathrm{F}$ & $\mathrm{P}$ \\
\hline Temperature (Temp) & 1 & $\mathbf{1 0 . 3 4 3}$ & 0.002 \\
Precipitation (Prec) & 3 & 1.198 & 0.326 \\
Temp X Prec & 3 & 0.705 & 0.556 \\
Time & 2 & 0.241 & 0.786 \\
Time X Temp & 2 & $\mathbf{3 . 2 5 6}$ & 0.044 \\
Time X Prec & 6 & 0.634 & 0.702 \\
Time X Temp X Prec & 6 & 1.065 & 0.393 \\
\hline
\end{tabular}

The interaction between time and temperature was also significant. The third week of the experiment (15 days), there was an increase in the concentration of Chl- $a$ in treatments simulating future climate change scenarios (Figure 4). There was no significant interaction between time and precipitation. However, at elevated temperatures, time has an important role in determining concentrations of Chl- $a$.

We used experimentally manipulated microcosms to evaluate the effects of precipitation (i.e. rainfall) and temperature on the Chlorophyll- $a$ concentration of a sampled phytoplankton community collected from a eutrophic environment with an ongoing cyanobacterial bloom (G. amphibium). Although previous multi-factorial studies have investigated the impacts of climate change, this is the first study to assess the combined effects of temperature and precipitation in tropical environments. We found that temperature was the factor responsible for increased Chl- $a$ concentrations in future climate change scenarios. 


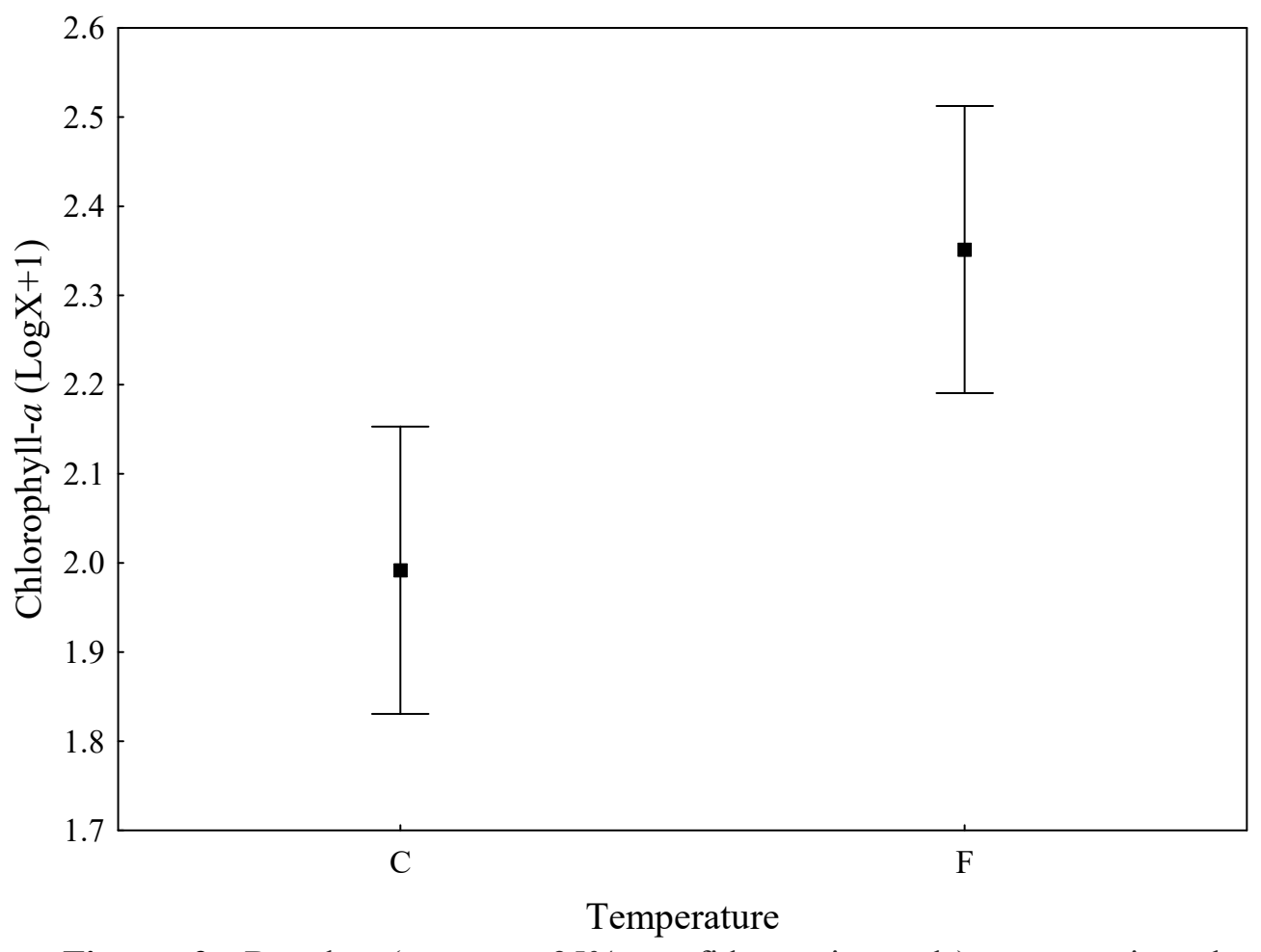

Figure 2. Boxplot (mean $\pm 95 \%$ confidence intervals) representing the concentration of Chlorophyll- $a$ in both simulated temperature conditions, where $\mathrm{C}$ is the current temperature and $\mathrm{F}$ the future temperature.

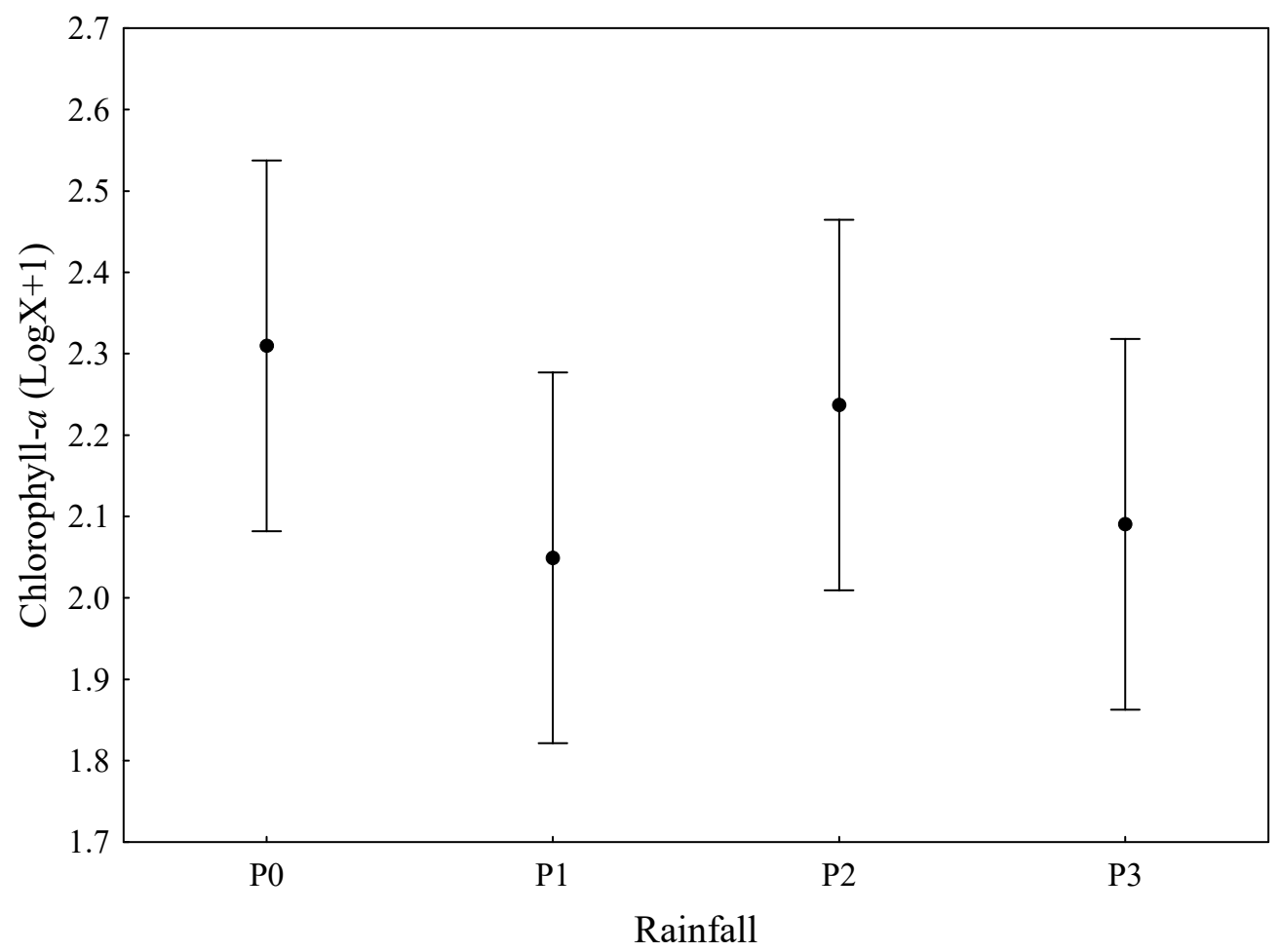

Figure 3. Boxplot (mean $\pm 95 \%$ confidence interval) representing the concentration of Chlorophyll- $a$ in the four simulated rainfall conditions (see details of $\mathrm{P} 0, \mathrm{P} 1, \mathrm{P} 2$, and $\mathrm{P} 3$ in methods). 


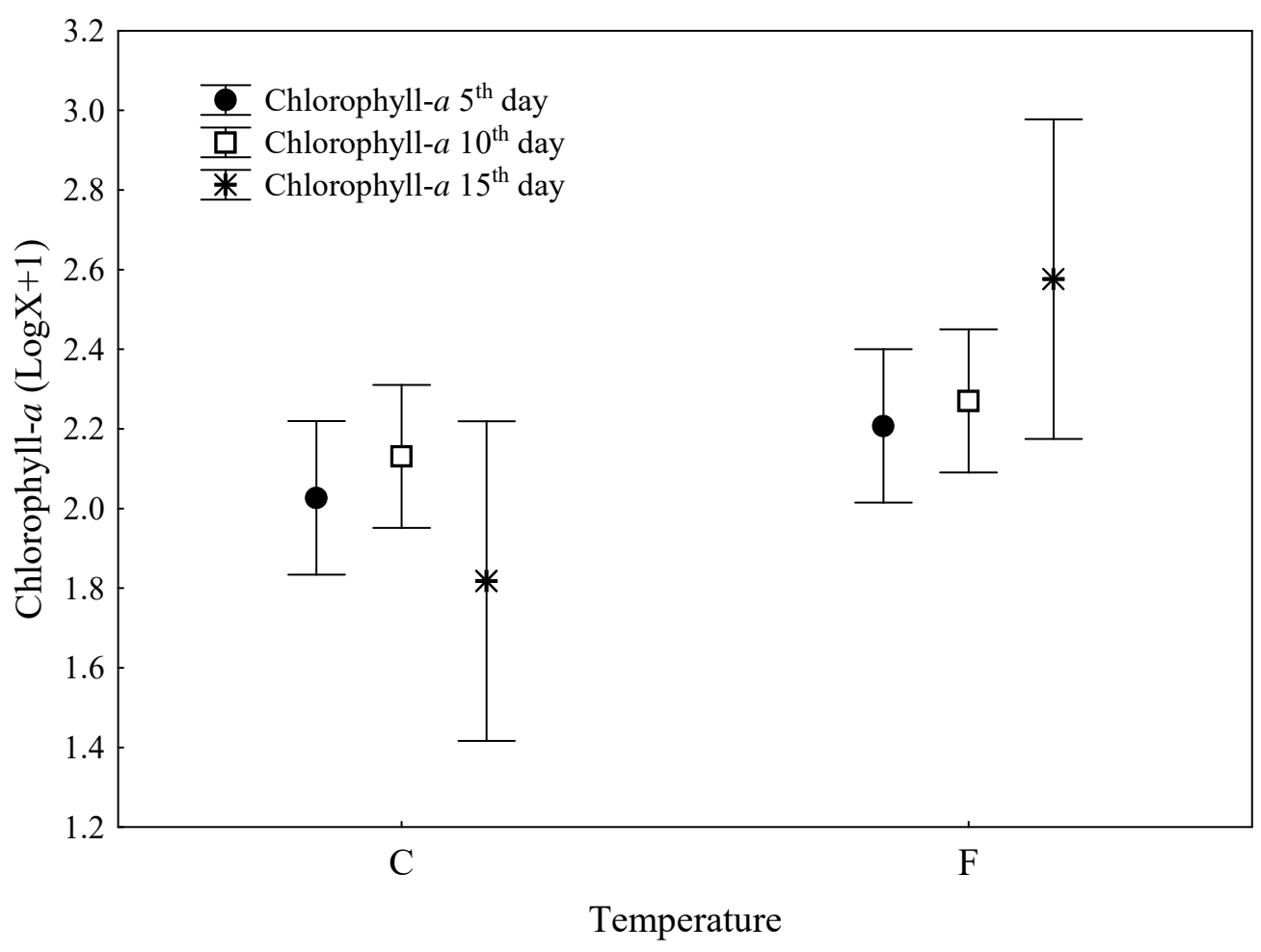

Figure 4. Boxplot (mean $\pm 95 \%$ confidence interval) representing the chlorophyll- $a$ concentration and the interaction effect among Temperature $(\mathrm{C}$ is current and $\mathrm{F}$ is Future) and time.

In fact, both thermal and hydrological changes can have serious consequences for aquatic ecosystems (Floury et al., 2012). Water temperature influences many processes in aquatic environments, including dissolved oxygen concentration (Gordon et al., 2004; Jeppesen et al., 2013), conductivity (Esteves et al., 2011), nutrient concentration (Jeppesen et al., 2009; 2011), and rates of primary productivity and decomposition (Lecerf et al., 2007).

Primary producers in aquatic environments are primarily controlled by nutrient availability, light (Huszar et al., 2006; Roland et al., 2012), and temperature (Roland et al., 2012). Temperature changes directly affect photosynthesis because higher temperatures accelerate the enzymatic reactions during photosynthesis and result in higher rates of primary productivity (Fernandes et al., 2005). Thus, algae growth tends to be linked with temperature, being faster at higher temperatures (Fernandes et al., 2005). Many cellular processes of algae depend on this variable (Reynolds, 1984). Moreover, many species of cyanobacteria are favored by an increase of temperature, promoting bloom events (see Moss et al., 2011; Jeppesen et al., $2013 ; 2014)$

An increase of water temperatures in the future may favor not only higher growth rates but may also increase the activity (Paerl and Huisman, 2009) and geographical distribution of cyanobacteria (Briand et al., 2004; Paerl and Huisman, 2009). Cyanobacterial blooms will likely be more frequent in future climatic conditions (Romo et al., 2005; Huber et al., 2012). This might be problematic because some species of cyanobacteria can produce toxic substances (Stewart et al., 2007; Paerl and Huisman, 2009) that can directly or indirectly contaminate other aquatic organisms through the food chain (Smith et al., 2008).

These blooms can also compromise the integrity of aquatic ecosystems by promoting massive oxygen consumption by algae and bacterial respiration during decomposition (Fernandes et al., 2005). In addition, cyanobacteria may be able to raise the local water 
temperature through light absorption, increasing their ability to dominate aquatic ecosystems (Paerl and Huisman, 2008).

In this study, precipitation does not affect the concentration of Chl- $a$; however, it was expected that concentrated rainfall can result in the dilution of nutrients and the washing away of algae blooms (Reichwaldt and Ghadouani, 2012) due to high discharge rates (Bouvy et al., 2003). In fact, the treatments (P1, P2, P3) presented higher Chl- $a$ concentrations than P0 (no precipitation) (see Figure 3). However, the possible nutrient dilution effect was compensated by the increase in temperature, promoting the growth of Chl- $a$ concentrations. Moreover, in microcosm the rainfall not remove the algae bloom (because of the physical limitations of the experiment); thus, even with the precipitation the original mass of the species was allowed to remain in the experiment, not being carried away. Finally, the addition of a large amount of water may interrupt the bloom and cause a lag in the resurgence of the algae bloom (Ahn et al., 2002), explaining the increase of Chl- $a$ in some treatments during the third week of the experiment.

However, it is still a challenge to provide precise answers regarding the consequences of climate change in aquatic ecosystems because there are a variety of Atmosphere-Ocean General Circulation Models (AOGCM), as well as climate scenarios (e.g. RCP 2.6, RCP 4.5, RCP6 and RCP 8.5). Current climate projections have a high degree of uncertainty, and this impedes the study of potential future impacts of warming. Microcosm experiments are one way to overcome this problem. This type of experiment provides important information about large-scale processes while only requiring minimal time to replicate different systems and scales (Benton et al., 2007). The use of microcosms in research is also supported by the need to tightly control conditions in order to correlate community dynamics with environmental variability. Future studies should consider the indirect effects of climate change, such as runoff, that are strongly influenced by the intensity of rain. Additionally, future studies investigating water temperature effects should also evaluate the uncertainty involved in choosing different climate change scenarios.

\section{CONCLUSIONS}

Based on our results, we reject our first hypothesis that extreme precipitation events increase Chl- $a$ concentrations relative to homogeneous rainfall. However, it is important to consider that in this study we evaluated the effect of precipitation on the dilution of the Chl- $a$. Our results supported our second hypothesis; higher temperatures favor higher Chl- $a$ concentrations. The future temperature used in this study (RCP 4.5) is based on intermediate greenhouse gas emissions, which would cause changes in the primary productivity of eutrophic environments.

This study also adds more information to a number of recent studies that investigate the impact of climate change on aquatic environments. In addition, the use of microcosm has proven to be satisfactory. Therefore, new studies using a similar approach may be undertaken, and different factors may be explored, such as new climatic scenarios and climatic variables.

\section{ACKNOWLEDGEMENTS}

We thank L.C.G Vieira and F.B. Teresa for suggestions on early versions of the experimental design and manuscript. We thank the two anonymous reviewers whose suggestions helped to improve the manuscript. We thank the CNPq (Process 473730/2013-8), CAPES (Process 2036/2013) and FAPEG (Process 201210267001071) for their financial support. Meirielle Euripa Pádua de Moura and Lorraine dos Santos Rocha thank Universidade

Rev. Ambient. Água vol. 12 n. 3 Taubaté - May / Jun. 2017 
Estadual de Goiás (UEG) and CNPq, respectively, for their scholarships. João Carlos Nabout thanks CNPq (Process 309700/2013-2) for the "Produtividade em Pesquisa" Scholarship.

\section{REFERENCES}

AHN, C. Y.; CHUNG, A. S.; OH, H. M. Rainfall, phycocyanin and N:P rations related to cyanobacterial blooms in a Korean large reservoir. Hydrobiologia, v. 474, n. 1-3), p. 117 124, 2002. http://dx.doi.org/10.1023/A:1016573225220

ANDERSEN, T.; PEDERSEN, O.; ANDERSEN, F. O. Nutrient concentration in a Littorella uniflora community at higher $\mathrm{CO}_{2}$ concentrations and reduced light intensities. Freshwater Biology, v. 50, p. 1178-1189, 2005. http://dx.doi.org/10.1111/j.13652427.2005.01390.x

BELNAP, J.; PHILLIPS, S. P.; MILLER, M. E. Response of desert biological soil crusts to alterations in precipitation frequency. Oecologia, v. 141, n.2, p. 306-316, 2005. http://dx.doi.org/10.1007/s00442-003-1438-6

BENTON, T. G.; SOLAN, M.; TRAVIS, J. J. J.; SAIT, S. M. Microcosm experiments can inform global ecological problems. Trends and Ecology \& Evolution, v. 22, n. 10, p. 516-521, 2007. http://dx.doi.org/10.1016/j.tree.2007.08.003

BERGER, S. A.; DIEHL, S.; STIBOR, H.; TROMMER, G E.; RUHENSTROTH, M. Water temperature and stratification depth independently shift cardinal events during plankton spring succession. Global Change Biology, v. 16, p. 1954-1965, 2010. http://dx.doi.org/10.1111/j.1365-2486.2009.02134.x

BOUVY, M.; NASCIMENTO, S. M.; MOLICA, R. J. R.; FERREIRA, A.; HUSZAR, V.; AZEVEDO, S. M. F. O. Limnological features in Tapacura reservoir (northeast Brazil) during a severe drought. Hydrobiologia, v. 493, n. 1-3, p. 115-130, 2003. http://dx.doi.org/10.1023/A:1025405817350

BRIAND, J. F.; LEBOULANGER, J. F.; HUMBERT, J. F.; BERNAND, C.; DUFOUR, P. Cylindrospermopsis raciborskii (Cyanobacteria) invasion at mid-latitudes: selection, wide physiological tolerance, or global warming? Journal of Phycology, v. 40 n. 2, p. 231-238, 2004. http://dx.doi.org/10.1111/j.1529-8817.2004.03118.x

CHRISTENSEN, M. R.; GRAHAM, M. D.; VINEBROOKE, R. D.; FINDLAY, D. L.; PATERSON, M. J. TURNER, M. A. Multiple anthropogenic stressors cause ecological surprises in boreal lakes. Global Change Biology, v. 12, p. 2316-2322, 2006. http://dx.doi.org/10.1111/j.1365-2486.2006.01257.x

CODD, G. A. Cyanobacterial toxins, the perception of water quality, and the prioritization of eutrophication control. Ecological Engineering, v. 16, p. 51-60, 2000. http://dx.doi.org/10.1016/S0925-8574(00)00089-6

COSTA, M. R. A.; ATTAYDE, J. L.; BECKER, V. Effects of water level reduction on the dynamics of phytoplankton functional groups in tropical semi-arid shallow lakes. Hydrobiologia, v. 778, n. 1, p. 75-89, 2015. http://dx.doi.org/10.1007/s10750-015-25936

DAUFRESNE, M.; LENGFELLNERA, K.; SOMMER, U. Global warming benefits the small in aquatic ecosystems. PNAS, v. 106, n. 31, p. 12788-12793, 2009. http://dx.doi.org/10.1073/pnas.0902080106 
DOLAN, J. R.; GALLEGOS, C. L.; MOIGIS, A. Dilution effects on microzooplankton in dilution grazing experiments. Marine Ecology Progress Series, v. 200, p. 127-139, 2000. http://dx.doi.org/10.3354/meps200127

DONEY, S. C.; FABRY, V. J.; FEELY, R. A. KLEYPAS, J. A. Ocean acidification: the other CO2 problem. Annual Review of Marine Science, v. 1, p. 169-192, 2009. http://dx.doi.org/10.1146/annurev.marine.010908.163834

ESTEVES, F. A.; FIGUEREDO-BARROS, M. P.; PETRUCIO, M. M. Principais Cátions e Ânions. In: ESTEVES, F. A. (Ed.). Fundamentos de Limnologia. 3. ed. Rio de Janeiro: Interciências, 2011. p. 299-319.

FERNANDES, L. F.; LAGOS, P. D.; WOSIACK, A. C.; PACHECO, C. V.; DOMINGUES, L.; ZENDER-ALVES, L. Comunidades fitoplanctônicas em ambientes lênticos. In: ANDREOLI, C. V.; CARNEIRO, C. (Eds.). Gestão integrada de mananciais de abastecimento eutrofizados. Curitiva: Finep, 2005.

FEUCHTMAYR, H.; MORAN, R.; HATTON, K.; CONNOR, L.; HEYES, T.; MOSS, B.; Harvey, I. et al. Global warming and eutrophication: effects on water chemistry and autotrophic communities in experimental hypertrophic shallow lake mesocosms. Journal of Applied Ecology, v. 46, p. 713-723, 2009. http://dx.doi.org/10.1111/j.13652664.2009.01644.x

FLOURY, M.; DELATTRE, C.; ORMEROD, S. J. SOUCHON, Y. Global versus local change effects on a large European river. Science of Total Environment, v. 441, p. 220-229, 2012. http://dx.doi.org/10.1016/j.scitotenv.2012.09.051

GOLTERMAN, H. L.; CLYMO, R. S.; OHMSTAD, M. A. M. Methods for physical and chemical analysis of freshwaters. Oxford: Blackwell Scientific Publication, 1978. 214 p.

GORDON, N. D.; FINLAYSON, B. L.; MCMAHON, T. A. Stream Hydrology an introduction for ecologists. 2. ed. London: John Wily \& Sons, 2004. 423p.

HE, H.; ZHU, X.; SONG, X.; JEPPESEN, E.; LIU, Z. Phytoplankton response to winter warming modified by large-bodied zooplankton: an experimental microcosm study. Journal of Limnology, v. 74, n. 3, p. 618-622, 2015. http://dx.doi.org/10.4 081/jlimnol.2015.1066

HOEGH-GUldBERG, O.; MUMBY, P. J.; HOOTEN, A. J.; STENECK, R. S.; GREENFIELD, P.; GOMEZ, E. et al. Coral reefs under rapid climate change and ocean acidification. Science, v. 318, p. 1737-1742, 2007. http://dx.doi.org/10.1 126/science. 1152509

HUBER, V.; WAGNER, C.; GERTEN, D.; ADRIAN, R. To bloom or not to bloom: contrasting responses of cyanobacteria to recent heat waves explained by critical thresholds of abiotic drivers. Oecologia, v. 169, p 245-256, 2012. http://dx.doi.org/10.1007/s00442-011-21867

HUSZAR, V. L. M.; CARACO, N. F.; ROLAND, F.; COLE, J. Nutrient-chlorophyll relationships in tropical-subtropical lakes: do temperate models fit? Biogeochemistry, $v$. 79, p. 239-250, 2006. http://dx.doi.org/10.1007/978-1-4020-5517-1_11 
INTERGOVERNMENTAL PAINEL ON CLIMATE CHANGE. Climate change: synthesis report. 2014 Available in: http://ar5-syr.ipcc.ch/topic_futurechanges.php. Access in: July 2015.

JEPPESEN, E.; KRONVANG, B.; JØRGENSEN, T. B.; LARSEN, S. E. ANDERSEN, H. E.; SØNDERGAARD, M. et al. Recent climate-induced changes in freshwaters in Denmark. In: GOLDMAN, C. R.; KUMAGAI, M.; ROBARTS, R. D. (Eds.). Climatic change and global warming of Inland waters: impacts and mitigation for ecosystems and societies. [S.1.]: John Wiley \& Sons, 2013. p. 155-171.

JEPPESEN, E.; KRONVANG, B.; MEERHOFF, M.; SØNDERGAARD, M.; HANSEN, K. M.; ANDERSEN, H. E. et al. Climate change effects on runoff, catchment phosphorus loading and lake ecological state, and potential adaptations. Journal of Environmental Quality, v. 38, p. 1930-1941, 2009. http://dx.doi.org/10.2134/jeq2008.0113

JEPPESEN, E.; KRONVANG, B.; OLESEN, J. E.; AUDET, J.; SØNDERGAARD, M.; HOFFMANN, C. C. et al. Climate change effect on nitrogen loading from catchment in Europe: implications for nitrogen retention and ecological state of lakes and adaptations. Hydrobiologia, v. 663, p. 1-21, 2011. http://dx.doi.org/10.1007/s10750-010-0547-6

JEPPESEN, E.; MEERHOFF, M.; DAVIDSON, T. A.; TROLLE, D.; SONDERGAARD, M.; LAURIDSEN, T. I. et al. Climate change impacts on lakes: an integrated ecological perspective based on multi-faced approach, with special focus on shallow lakes. Journal of Limnology, v. 73, p. 88-111, 2014. http://dx.doi.org/10.4081/jlimnol.2014.844

JEPPESEN, E.; MOSS, B.; BENNION, H.; CARVALHO, L.; DE MEESTER, L. et al. Interaction of climate change and eutrophication. In: KERNAN, M.; BATTARBEE, R.; MOSS, B. (Eds.). Climate change impacts on freshwater ecosystems. Oxford: WileyBlackwell, 2010. p. 119-151.

JEZNACH, L. C.; TOBIASON, J. E. Future climate effects on thermal stratification in the Wachusett Reservoir. Journal AWWA, v. 107, n. 4, p. E197-E209, 2015. http://dx.doi.org/10.5942/jawwa.2015.107.0039

KOPEC, R. J. Global climate change and impact of a maximum sea level on coastal settlement. Journal of Geography, v. 70, p. 541-550, 1971. http://dx.doi.org/10.1 080/00221347108981908

KOSTEN, S.; HUSZAR, V. L.; BÉCARES, E.; COSTA, L. S.; DONK, E.; HANSSON, L. A. et al. Warmer climates boost cyanobacterial dominance in shallow lakes. Global Change Biology, v. 18, n. 1, p. 118-126, 2012. http://dx.doi.org/10.1111/j.1365-2486. 2011.02488.x

LECERF, A.; RISNOVEANU, G.; POPESCU, C.; GESSNER, M. O.; CHAUVET, E. Decomposition of diverse litter mixtures in streams. Ecology, v. 88, p. 219-227, 2007. http://dx.doi.org/10.1890/0012-9658(2007)88[219:DODLMI]2.0.CO;2

LI, Z.; HE, L.; ZHANG, H.; URRUTIA-CORDERO, P.; EKVALL, M. K.; HOLLANDER, J.; et al. Climate warming and heat waves affect reproductive strategies and interactions between submerged macrophytes. Global change biology, v. 23, n. 1, p. 108-116, 2017. http://dx.doi.org/10.1111/gcb.13405 
LI, W.; XU, X.; FUJIBAYASHI, M.; NIU, Q.; TANAKA, N.; NISHIMURA, O. Response of microalgae to elevated $\mathrm{CO}_{2}$ and temperature: impact of climate change on freshwater ecosystems. Environmental Science and Pollution Research, v. 23, n. 19, p. 1984719860, 2016. http://dx.doi.org/10.1007/s11356-016-7180-5

LIMA-RIBEIRO, M. S.; VARELA, S.; GONZÁLEZ-HERNÁNDEZ, J.; OLIVEIRA, G.; DINIZ-FILHO, J. A. F.; TERRIBILE, L. C. EcoClimate: a database of climate data from multiple models for past, present, and future for Macro ecologists and Biogeographers. Biodiversity Informatics, v. 10, p. 1-21, 2015. https://doi.org/10.17161/bi.v10i0.4955

MARENGO, J. A.; JONES, R.; ALVES, L. M.; VALVERDE, M. C. Future change of temperature and precipitation extremes in South America as derived from the PRECIS regional climate modeling system. International Journal of Climatology, v. 29, n. 15, p. 2241-2255, 2009. http://dx.doi.org/10.1002/joc.1863

MEERHOFF, M.; CLEMENTE, J. M.; MELLO, F. T.; IGLESIAS, C.; PEDERSEN, A. R.; JEPPESEN, E. Can warm climate-related structure of littoral predator assemblies weaken the clear water state in shallow lakes? Global Change Biology, v. 13, p. 1888-1897, 2007. http://dx.doi.org/10.1111/j.1365-2486.2007.01408.x

MOSS, B.; KOSTEN, S.; MEERHOFF, M.; BATTARBEE, R. W.; JEPPESEN, E.; MAZZEO, N. et al. Allied attack: climate change and eutrophication. Inland waters, v. 1, n. 2, p. 101-105, 2011.

MOSS, B.; MCKEE, D.; ATKINSON, D.; COLLINGS, S. E.; EATON, J. W.; GILL, A. B. et al. How important is climate? Effects of warming, nutrient addition and fish on phytoplankton in shallow lake microcosms. Journal of Applied Ecology, v. 40, p. 782 792, 2003. http://dx.doi.org/10.1046/j.1365-2664.2003.00839.x

MOWE, M. A.; MITROVIC, S. M.; LIM, R. P.; FUREY, A.; YEO, D. C. Tropical cyanobacterial blooms: a review of prevalence, problem taxa, toxins and influencing environmental factors. Journal of Limnology, v. 74, n. 2, p. 205-224, 2015a. http://dx.doi.org/10.4081/jlimnol.2014.1005

MOWE, M. A.; POROJAN, C.; ABBAS, F.; MITROVIC, S. M.; LIM, R. P.; FUREY, A. Rising temperatures may increase growth rates and microcystin production in tropical Microcystis species. Harmful Algae, v. 50, p. 88-98, 2015 b. http://dx.doi.org/10.1016/j.hal.2015.10.011

NABOUT, J. C.; CARVALHO, P.; PRADO, U. M.; BORGES, P. P.; MACHADO, K. B.; HADDAD, K. B. et al. Trends and biases in global climate change literature. Natureza \& Conservação, v. 10, p. 45-51, 2012 a.

NABOUT, J. C.; CAETANO, J. M.; FERREIRA, R. B.; TEIXEIRA, I. R.; ALVES, S. M. F. Using correlative, mechanistic and hybrid niche models to predict the productivity and impact of global climate change on maize crop in Brazil. Natureza \& Conservação, v. 10, p. $177-183,2012$ b.

NICKUS, U.; BISHOP, K.; ERLANDSSON, M.; EVANS, C. D.; FORSIUS, M.; LAUDON, H. et al. Direct impacts of climate change on freshwater ecosystems. In: KERNAN, M.; BATTARBEE, R. W.; MOSS, B. (Ed.). Climate change impacts on freshwater ecosystems. India: Wiley-Blackwell, 2010. 
PAERL, H.W.; HUISMAN, J. Blooms like it hot. Science, v. 320, p. 57-58, 2008. http://dx.doi.org/10.1111/j.1758-2229.2008.00004.x

PAERL, H.W.; HUISMAN, J. Climate Change: a catalyst for global expansion of harmful cyanobacterial blooms. Environmental Microbiology Report, v. 1, p. 27-37, 2009. http://dx.doi.org/10.1111/j.1758-2229.2008.00004.x

PAZ, S. Climate change impacts on West Nile virus transmission in a global context. Philosophical Transactions of the Royal Society. B., v. 370, p. 1-11, 2015. http://dx.doi.org/10.1098/rstb.2013.0561

PENDERGRASS, A. G.; HARTMANN, D. L. Global-mean precipitation and black carbono in AR4 simulations. Geophysical Research Letters, v. 39, n. 1, 2012. http://dx.doi.org/10.1029/2011GL050067

REICHWALDT, E. S.; GHADOUANI, A. Effects of rainfall patterns on toxic cyanobacterial blooms in a changing climate: Between simplistic scenarios and complex dynamics. Water Research, v. 46, p. 1372-1393, 2012. http://dx.doi.org/10.1016/j.watres.2011.11.052

REYNOLDS, C. S. The ecology of freshwater phytoplankton. Cambridge: University Press, 1984.

ROCKSTRÖM, J.; BRASSEUR, G.; HOSKINS, B.; LUCHT, W.; SCHELLNHUBER, J.; KABAT, P. et al. Climate change: The necessary, the possible and the desirable Earth league climate statement on the implications for climate policy from the 5th IPCC assessment. Earth's Future, v. 2, p. 606-611, 2014.

http://dx.doi.org/10.1002/2014EF000280

ROLAND, F.; HUSZAR, V. L. M.; FARJALLA, V. F.; ENRICH-PRAST, A.; AMADO, A. M. et al. Climate change in Brazil: perspective on the biogeochemistry of inland waters. Brazilian Journal of Biology, v. 72, p. 709-722, 2012. http://dx.doi.org/10.1590/S151969842012000400009

ROMO, S.; VILLENA, M. J.; SAHUQUILLO, M.; SORIA, J. M.; GIMENEZ, M.; ALFONSO, $\mathrm{T}$. et al. Response of a shallow Mediterranean lake to nutrient diversion: does it follow similar patterns as in northern shallow lakes? Freshwater Biology, v. 50, p. 1706-17, 2005. http://dx.doi.org/10.1111/j.1365-2427.2005.01432.x

SEIP, K. L.; REYNOLDS, C. S. Phytoplankton functional attributes along trophic gradient and season. Limnology and Oceanography, v. 40, p. 589-597, 1995.

http://dx.doi.org/10.4319/lo.1995.40.3.0589

SHORT, F. T.; KOSTEN, S.; MORGAN, P. A.; MALONE, S.; MOORE, G. E. Impacts of climate change on submerged and emergent wetland plants. Aquatic Botany, v. 135, p. 3-17, 2016. http://dx.doi.org/10.1016/j.aquabot.2016.06.006

SMITH, J. L.; BOYER, G. L.; ZIMBA, P. V. A review of cyanobacterial odorous and bioactive metabolites: Impacts and management alternatives in aquaculture. Aquaculture, v. 280, p. 5-20, 2008. http://dx.doi.org/10.1016/j.aquaculture.2008.05.007

STEWART, I.; SEAWRIGHT, A. A.; SHAW, G. R. Cyanobacterial poisoning in livestock, wild mammals and birds -- an overview. In: HUDNELL, H. K. (Ed.). Cyanobacterial harmful algal blooms: state of the science and research needs. [S.1.]: Springer, 2007. 
TUNDISI, J. G.; MATSUMURA-TUNDISI, T.; TUNDISI, J. E. M.; BLANCO, F. P.; ABE, D. S.; CONTRI, C. L. et al. A bloom of cyanobacteria (Cylindrospermopsis raciborskii) in UHE Carlos Botelho (Lobo/Broa) reservoir: a consequence of global change? Brazilian Journal of Biolology, v. 75, n. 2, p. 507-508, 2015. http://dx.doi.org/10.1590/1519-6984.24914

VAN DE BUND, W. J.; ROMO, S.; VILLENA, M. J.; VALENTIN, M.; VAN DONK, E.; VICENTE, K. Responses of phytoplankton to fish predation and nutrient loading in shallow lakes: a pan-European mesocosm experiment. Freshwater Biology, v. 49, n. 12, p. 1608-1618, 2004. http://dx.doi.org/10.1111/j.1365-2427.2004.01307.x

YVON-DUROCHER, G.; ALLEN, A. P.; MONTOYA, J. M.; TRIMMER, M.; WOODWARD, G. The temperature dependence of carbon cycle in aquatic ecosystems. Avdances in Ecological Research, v. 43, p. 267-313, 2010. http://dx.doi.org/10.1016/B978-0-12-385005-8.00007-1

YVON-DUROCHER, G.; ALLEN, A.P.; CELLAMARE, M.; DOSSENA, M.; GASTON, K. J.; LEITAO, M. et al. Five years of experimental warming increases the biodiversity and productivity of phytoplankton. PLoS Biology, v. 13, n. 12, 2015. http://dx.doi.org/10.1371/journal.pbio.1002324

ZAR, J. H. Biostatistical Analysis. 5. ed. [S.1.]: Pearson, 2010. 


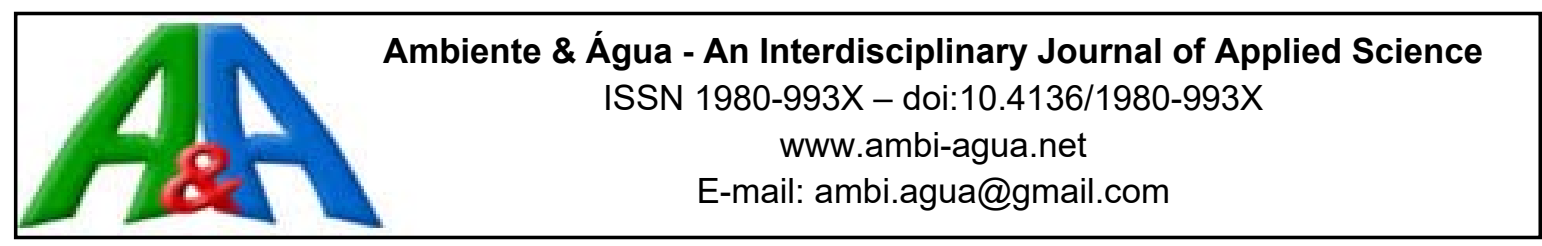

\title{
Initial development of cowpea plants under salt stress and phosphate fertilization
}

\author{
doi:10.4136/ambi-agua.2070
}

Received: 25 Dec. 2016; Accepted: 24 Mar. 2017

\author{
Francisco Vanies da Silva Sá ${ }^{*}$; Miguel Ferreira Neto ${ }^{2}$; Yuri Bezerra de Lima ${ }^{3}$; \\ Emanoela Pereira de Paiva ${ }^{3}$; Hans Raj Gheyi ${ }^{4}$; Nildo da Silva Dias ${ }^{2}$ \\ ${ }^{1}$ Universidade Federal de Campina Grande (UFCG), Campina Grande, PB, Brasil \\ Departamento de Recurso Naturais \\ ${ }^{2}$ Universidade Federal Rural do Semi-Árido (UFERSA), Mossoró, RN, Brasil \\ Departamento de Ciências Ambientais e Tecnológicas \\ ${ }^{3}$ Universidade Federal Rural do Semi-Árido (UFERSA), Mossoró, RN, Brasil \\ Departamento de Ciências Vegetais \\ ${ }^{4}$ Universidade Federal do Recôncavo da Bahia (UFRB), Cruz das Almas, BA, Brasil \\ Departamento de Núcleo de Engenharia de Água e Solo \\ *Autor correspondente: e-mail: vanies_agronomia@hotmail.com, \\ miguel@ufersa.edu.br, yuribzdlima@hotmail.com, emanuelappaiva@hotmail.com, \\ hans@pq.cnpq.br,nildo@ufersa.edu.br
}

\begin{abstract}
The objective of this work was to study the effects of irrigation with saline water associated with phosphate fertilization on the emergence and early growth of cowpea plants. The assay was conducted in the greenhouse of the Department of Environmental Sciences and Technology of the Federal Rural University of the Semi-Arid (UFERSA) in Mossoró-RN, during October and November of 2015. The study adopted a randomized block with treatments arranged in a $5 \times 3$ grid, corresponding to five levels of water salinity $\left(0.5,1.5,2.5,3.5\right.$ and $\left.4.5 \mathrm{dS} \mathrm{m}^{-1}\right)$ and three doses of superphosphate, based upon the soil analysis $(60 \%, 100 \%$ and $140 \%$ of the recommended dose for the crop $60 \mathrm{~kg} \mathrm{P}_{2} \mathrm{O}_{5} \mathrm{ha}^{-1}$ ), with five repetitions. The cowpea plants, $\mathrm{cv}$. Paulistinha, were grown in lysimeters with capacity of $8 \mathrm{dm}^{3}$. During the first 15 days of the initial stage of development the plants were evaluated for emergence, growth and biomass accumulation. The increase in water salinity above $1.5 \mathrm{dSm}^{-1}$ reduced the emergence, growth and dry matter accumulation of cowpea plants. The increase of $40 \%$ in the recommendation of phosphorus fertilization of cowpea increased the growth and biomass accumulation of shoot plants, regardless of salinity.
\end{abstract}

Keywords: saline water, soil and water management, Vigna unguiculata.

\section{Desenvolvimento inicial de plantas de feijão-caupi sob estresse salino e adubação fosfatada}

\section{RESUMO}

Objetivou-se estudar os efeitos da irrigação com água salina associada à adubação fosfatada com superfosfato simples na emergência e crescimento inicial de plantas de feijão-caupi. A pesquisa foi realizada em casa de vegetação do Departamento de Ciências Ambientais e Tecnológicas da Universidade Federal Rural do Semi-Árido (UFERSA), em 
Mossoró-RN, no período de outubro a novembro de 2015, no delineamento experimental de blocos casualizados com tratamentos arranjados em esquema fatorial $5 \times 3$, relativos a cinco

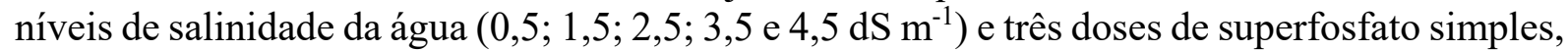
tendo como base a análise de solo $(60 \%, 100 \%$ e $140 \%$ da dose recomendada para a cultura- 60 $\mathrm{kg} \mathrm{P}_{2} \mathrm{O}_{5}$ ha $^{-1}$ ), com cinco repetições. As plantas de feijão-caupi cv. Paulistinha foram cultivadas em lisímetros com capacidade de $8 \mathrm{dm}^{3}$. Durante os primeiros 15 dias da fase inicial de desenvolvimento, as plantas foram avaliadas quanto à emergência, crescimento e acúmulo de biomassa. $\mathrm{O}$ aumento da salinidade da água de irrigação acima de $1,5 \mathrm{dS} \mathrm{m}^{-1}$ reduziu a emergência, o crescimento e o acúmulo de massa seca das plantas de feijão-caupi. O incremento de $40 \%$ na recomendação da adubação fosfatada do feijão-caupi promoveu incrementos no crescimento e no acúmulo de biomassa da parte aérea da planta, independente da salinidade.

Palavras-chave: água salina, manejo de solo e água, Vigna unguiculata.

\section{INTRODUCTION}

Cowpea, Vigna unguiculata (L.) Walp., is a socioeconomically important crop in Brazil, supplementing food supplies and employing farm workers, especially in the North and Northeast regions (Rocha et al., 2009). Although the Northeast is the main producing region, accounting for $90 \%$ of the Brazilian cowpea crop (Bezerra et al., 2010), the limited availability of water, particularly in the northeastern semi-arid portion, means the crops must be irrigated to achieve satisfactory yields. The high sensitivity of cowpea plants to water deficiencies in the soil, combined with differing amounts of variations in rainfall in different years and cultivation areas, causes great variations in the annual yields of this crop (Mousinho et al., 2008).

Irrigation is a necessary practice for the adequate development and production of the plants. However, besides quantitative aspects, the region also faces factors of qualitative nature, such as the excess of salts in the water (Medeiros et al., 2007). Thus, inadequate irrigation management increases the salt content of the soil, promoting its salinization, which in turn reduces the capacity of plants to absorb water, causing metabolic alterations identical to those caused by water stress (Munns and Tester, 2008). In addition, inadequate irrigation has indirect effects such as toxicity by specific ions, for example, salts of sodium and chlorine (Syvertsen and Garcia-Sanchez, 2014).

In the evaluation of three cowpea cultivars, Patel et al. (2010) and Coelho et al. (2013) observed that there were drastic reductions in the biomass accumulation of the plants with the increase in irrigation water salinity. These authors claimed that the increase in water salinity led to increments of salts in the soil, making it unproductive for the crop. It becomes necessary to adopt strategies that go beyond irrigation management, such as the management of mineral and organic fertilizers along with irrigation management, to assist in the maintenance of soil salinity and sodicity.

Among the fertilization strategies, phosphate fertilization stands out, because it is crucial to obtain satisfactory crop yields and, additionally, phosphorus $(\mathrm{P})$ is the most problematic nutrient for Brazilian soils, due to its low availability and mobility in the soil (Santos et al., 2008). Among the phosphate fertilizers, single superphosphate has the highest potential in soils with salinity and sodicity problems, because it is formulated based on P, calcium and sulfur. In addition to meeting the demand for $\mathrm{P}$, the presence of calcium sulfate (gypsum) favors the supplementation of calcium and sulfur (Lopes et al., 2010), besides the competition between calcium and sodium ions in the exchange complex and in the soil solution, reducing the effects of sodicity (Sousa et al., 2012; Sá et al., 2013; 2015; Mesquita et al., 2015). 
However, the interaction of salinity vs. phosphate fertilization is still little-studied for most crops, including cowpea. In studies conducted by Oliveira et al. (2010), the authors observed that the quality of irrigation water directly influences the determination of phosphate fertilization, which is more efficient for waters of low salinity. Thus, the objective of this work was to study the effects of irrigation with saline water associated with phosphate fertilization using single a superphosphate at the emergence and initial growth of cowpea plants.

\section{MATERIAL AND METHODS}

The study was carried out in a greenhouse of the Department of Environmental and Technological Sciences of the Federal Rural University of the Semi-Arid Region (UFERSA), in Mossoró-RN, from October to November 2015. The municipality of Mossoró is located in the semi-arid region of Northeast Brazil, at the local geographic coordinates of $5^{\circ} 11^{\prime} 31^{\prime \prime} \mathrm{S}$ and $37^{\circ} 20^{\prime} 40^{\prime}$ ' $\mathrm{W}$, at an altitude of $18 \mathrm{~m}$.

The experiment was conducted in a completely randomized design, in $5 \times 3$ grid scheme, formed by five levels of irrigation water salinity $\left(\mathrm{S}_{1}=0.5 ; \mathrm{S}_{2}=1.5 ; \mathrm{S}_{3}=2.5 ; \mathrm{S}_{4}=3.5\right.$; $\left.\mathrm{S}_{5}=4.5 \mathrm{dS} \mathrm{m}^{-1}\right)$ and three doses of phosphate fertilization with single superphosphate $\left(\mathrm{A}_{1}=\right.$ $60 \% ; \mathrm{A}_{2}=100 \%$ and $\mathrm{A}_{3}=140 \%$ of the dose of $60 \mathrm{~kg} \mathrm{P}_{2} \mathrm{O}_{5} \mathrm{ha}^{-1}$, recommended by Cavalcanti et al., 2008), with 5 replicates, totaling 75 experimental plots.

The $\mathrm{P}$ doses were calculated based on the soil analysis and the soil used in the experiment came from a virgin area of the experimental farm of the UFERSA, Campus of Mossoró, classified as latosolic Red-Yellow Argisol. The soil samples were collected in the layer of 0-30 cm and analyzed at the Laboratory of Analysis of Soils, Water and Plant - LASAP, of the UFERSA, following the methodology of EMBRAPA (2011) (Table 1).

Table 1. Physical and chemical characteristics of the soil collected in the layer of $0-30 \mathrm{~cm}$ and the bovine manure used in cowpea cultivation.

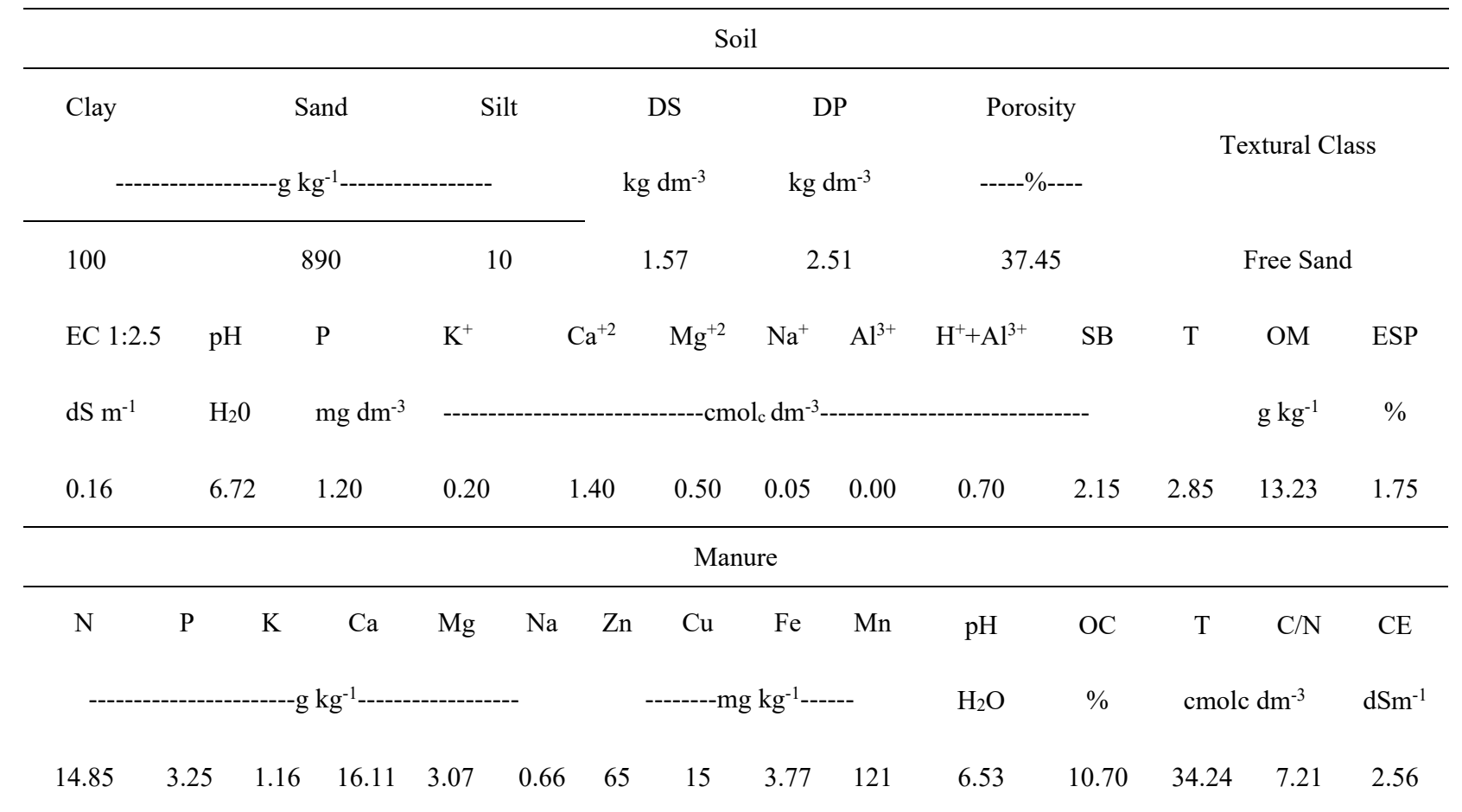

Note: $\mathrm{P}, \mathrm{K}^{+}, \mathrm{Na}^{+}$: extracted by Mehlich $1 ; \mathrm{Al}^{3+}, \mathrm{Ca}^{2+}, \mathrm{Mg}^{2+}$ : extracted by $1.0 \mathrm{~mol} \mathrm{~L}{ }^{-1} \mathrm{KCl}$; DS: Soil bulk density; DP: Soil particle density; EC: Electrical conductivity; SB: Sum of bases; T: Cation exchange capacity; OM: Walkley-Black wet digestion; ESP: Exchangeable sodium percentage; OC: Organic Carbon. 
Fertilization was based on the technical bulletin of recommendation of fertilization for the state of Pernambuco (Cavalcanti et al., 2008). The recommendation for the cowpea crop is 60 $\mathrm{kg} \mathrm{ha}^{-1}$ of $\mathrm{P}_{2} \mathrm{O}_{5}, 20 \mathrm{~kg} \mathrm{ha}^{-1}$ of $\mathrm{K}_{2} \mathrm{O}$ and $50 \mathrm{~kg} \mathrm{ha}^{-1}$ of $\mathrm{N}$ for one crop cycle, also adding $15 \mathrm{~kg} \mathrm{ha}^{-1}$ of $\mathrm{Mg}$ in the form of $\mathrm{MgSO}_{4}$. The recommendation of fertilization was used to establish the doses of $\mathrm{P}_{2} \mathrm{O}_{5}\left(\mathrm{~A}_{1}=36 ; \mathrm{A}_{2}=60\right.$ and $\left.\mathrm{A}_{3}=84 \mathrm{~kg} \mathrm{ha}^{-1}\right)$ applied as basal in the form of single superphosphate $\left(\mathrm{A}_{1}=0.7 ; \mathrm{A}_{2}=1.17\right.$ and $\mathrm{A}_{3}=1.64 \mathrm{~g} \mathrm{pot}^{-1}$ of $\left.\mathrm{P}_{2} \mathrm{O}_{5}\right)$, while planting was performed after 20 days. During this period, the soil was maintained with moisture content close to its maximum water holding capacity.

After physical and chemical characterization of the soil and establishment of fertilizations, the soil was put in lysimeters with capacity for $8 \mathrm{dm}^{3}$, of which $7 \mathrm{dm}^{3}$ were filled by soil, $0.5 \mathrm{dm}^{3}$ by bovine manure and $0.5 \mathrm{dm}^{3}$ by crushed stone at the bottom, to facilitate drainage. The lysimeters were filled in the following sequence: screen, crushed stone; $2 \mathrm{dm}^{3}$ of soil; and the mixture of soil $\left(5 \mathrm{dm}^{3}\right)$, manure $\left(0.5 \mathrm{dm}^{3}\right)$ and the $\mathrm{P}$ doses established for each treatment.

After preparation, the soil was irrigated to remain close to its maximum water holding capacity and subsequent irrigations were performed once a day to keep the soil close to its maximum retention capacity, based on the method of drainage lysimetry. The applied water depth was supplemented by a leaching fraction (LF) of 0.20 every seven days. The volume applied $\left(\mathrm{V}_{\mathrm{a}}\right)$ per container was obtained by the difference between the previous water depth $\left(\mathrm{L}_{\text {prev }}\right)$ and the mean drainage (D), divided by the number of containers (n), as indicated in Equation 1.

$$
V_{a}=\frac{V_{\text {prev }}-(D / n)}{1-L F}
$$

The waters with different saline levels were prepared by the addition of sodium chloride $(\mathrm{NaCl})$, which accounts for $70 \%$ of the salt ions in water sources used for irrigation in small properties of Northeast Brazil (Medeiros et al., 2007). The solutions were prepared using water from the local supply system $\left(\mathrm{ECW}=0.53 \mathrm{dS} \mathrm{m}^{-1}\right)$, which was mixed with the salts as necessary. After preparation, the salinized waters were stored in 150-L plastic containers, one for each studied ECW level, properly protected to avoid evaporation, entry of rain water and contamination with materials that could compromise their quality. To prepare the waters, with the specific values of electrical conductivity (EC), the salts were weighed according to the treatment and water was added until the desired EC level was achieved. The values were monitored with a portable conductivity meter, with conductivity adjusted to the temperature of $25^{\circ} \mathrm{C}$.

After irrigation, the cowpea cv. 'Paulistinha' was sown on October 14, 2015, using 10 seeds per pot. Fifteen days after sowing, with total emergence of the plantlets, thinning was performed, leaving only three plants per pot. The number of emerged plantlets (cotyledons above the soil level) was counted, without discarding them, thus obtaining a cumulative value. Hence, the number of emerged plantlets referring to each count was obtained by subtracting the reading of the previous day from the value of the current day. The number of emerged plantlets referring to each reading was used to calculate the mean time of emergence (MTE), emergence speed index (ESI) and the emergence speed coefficient (ESC), according to the Equations 2, 3 and 4 described by Schuab et al. (2006).

$$
\operatorname{MTE}=\frac{\left(N_{1} G_{1}\right)+\left(N_{2} G_{2}\right)+\cdots+\left(N_{n} G_{n}\right)}{G_{1}+G_{2}+\cdots+G_{n}}
$$

Rev. Ambient. Água vol. 12 n. 3 Taubaté - May / Jun. 2017 


$$
\begin{aligned}
& \mathrm{ESI}=\frac{\left(\mathrm{N}_{1}\right)+\left(\mathrm{N}_{2}\right)+\cdots+\left(\mathrm{N}_{\mathrm{n}}\right)}{\mathrm{G}_{1}+\mathrm{G}_{2}+\cdots+\mathrm{G}_{\mathrm{n}}} \\
& \mathrm{ESC}=\frac{\mathrm{G}_{1}+\mathrm{G}_{2}+\cdots+\mathrm{G}_{\mathrm{n}}}{\left(\mathrm{N}_{1} \mathrm{G}_{1}\right)+\left(\mathrm{N}_{2} \mathrm{G}_{2}\right)+\cdots+\left(\mathrm{N}_{\mathrm{n}} \mathrm{G}_{\mathrm{n}}\right)} \times 100
\end{aligned}
$$

where:

$$
\begin{aligned}
& \text { MTE = Mean time of emergence (days); } \\
& \text { G = number of emerged plantlets in each count; } \\
& \mathrm{N}=\text { number of days from sowing to each count; } \\
& \text { ESI = emergence speed index; and } \\
& \text { ESC = emergence speed coefficient. }
\end{aligned}
$$

After stabilization of emergence at 10 days after sowing, emergence percentage (EP) was determined using the relationship between the number of emerged plants and the number of planted seeds.

The initial growth of cowpea plantlets was monitored 15 days after sowing based on the evaluation of plant height $(\mathrm{PH})$; stem diameter $(\mathrm{SD})(\mathrm{mm})$, measured with a digital caliper at the base of the plants; and the number of leaves (NL), determined through the count of mature leaves. Three plants were collected, separated into shoots (leaves + stem) and roots, and dried in a forced-air oven at $65^{\circ} \mathrm{C}$ until constant weight. Then, the material was weighed on an analytical scale with precision of $0.0001 \mathrm{~g}$. These data were used to calculate leaf dry matter (LDM) (g), stem dry matter (StDM) (g) and total shoot dry matter (ShDM) (g).

The obtained data were subjected to analysis of variance by $F$ test at 0.05 probability level. In case of significance, polynomial regression analysis was applied for the factor irrigation water salinity and test of means (Tukey) was applied for the factor phosphate fertilization, both at 0.05 probability level, using the statistical software SISVAR ${ }^{\circledR}$ (Ferreira, 2011).

\section{RESULTS AND DISCUSSION}

Irrigation water salinity affected the emergence of cowpea plants, with reductions of $21.1 \%$ in the emergence of plants cultivated at the lowest salinity level $\left(0.5 \mathrm{dS} \mathrm{m}^{-1}\right)$ in comparison to those at the highest level $\left(4.5 \mathrm{dS} \mathrm{m}^{-1}\right)$ (Figure 1A). For MTE, there was an increment in the time required for total emergence, so that plants irrigated with high saline level $\left(4.5 \mathrm{dS} \mathrm{m}^{-1}\right)$ required $12.4 \%$ more time to emerge, in relation to the control $\left(0.5 \mathrm{dS} \mathrm{m}^{-1}\right)$ (Figure $\left.1 \mathrm{~B}\right)$.

There was a decrease in the ESI of cowpea plants due to the increase in irrigation water salinity, with reductions of $7.2 \%$ per unit increase in water salinity (Figure 1C). Still regarding the emergence of cowpea plantlets, the decrease in the number of emerged seeds, as well as in the emergence speed, caused by the salt stress, linearly reduced the ESC (Figure 1D), which expresses the uniformity of emergence of the plants, indicating that the salt stress affected the physiological potential of the seeds and plantlets that emerged at a high salinity level, causing a reduction of vigor and possibly the death of the plants still in the germination stage. This probably occurred due to the reduction in the osmotic potential caused by the increase in the contents of $\mathrm{NaCl}$ in the soil, besides the toxicity caused by these ions, decreasing the viability of the seeds and the emergence of the plantlets (Munns and Tester, 2008; Voigt et al., 2009; Dantas et al., 2011; Taiz and Zeiger, 2013). 
A
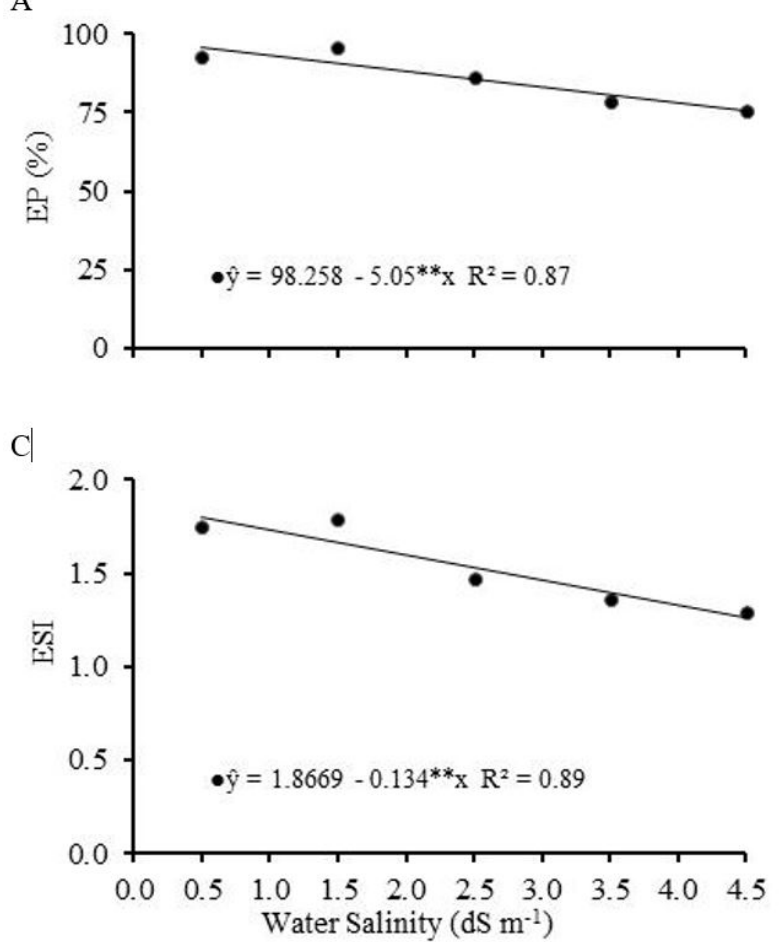

B

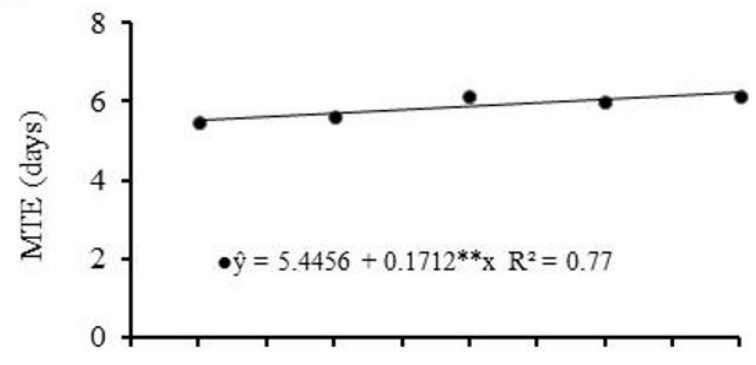

$\mathrm{D}$

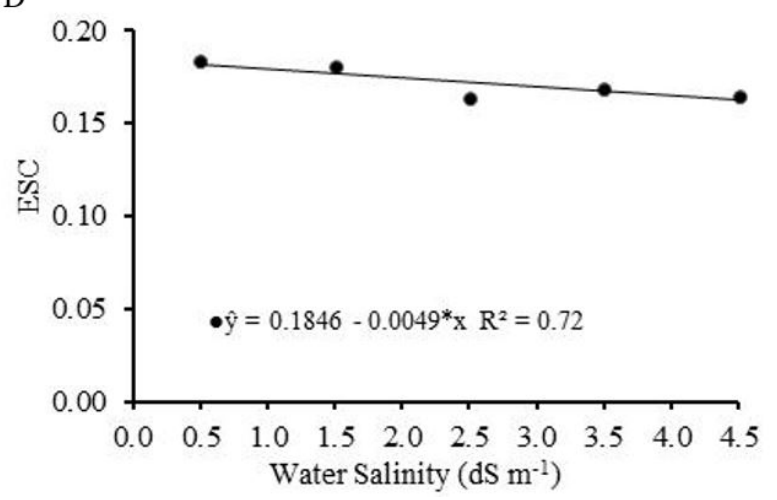

Figure 1. Emergence percentage (EP) (A), mean time of emergence (MTE) (B), emergence speed index (ESI) (C) and emergence speed coefficient (ESC) (D) of cowpea plantlets, cv. Paulistinha, under different levels of water salinity, at 15 days after sowing.

Note: $*$ and $* *=$ significant at 5 and $1 \%$ probability $(\mathrm{p}<0.05$ and $\mathrm{p}<0.01)$.

The increase in salinity linearly reduced the height and stem diameter of cowpea plants at rates of $0.76 \mathrm{~cm}$ and $0.17 \mathrm{~mm}$ per $\mathrm{dS} \mathrm{m}^{-1}$, respectively (Figure $2 \mathrm{~A}$ and $\mathrm{C}$ ). For plant height, the management of phosphate fertilization also had a significant effect, so that plants showed the highest growth when fertilized with $40 \%$ more of $\mathrm{P}_{2} \mathrm{O}_{5}$ (Figure $2 \mathrm{~B}$ ). These results express the positive effect of phosphate fertilization on the nutritional aspects of cowpea plants, promoting increments in the growth in height, regardless of the salinity condition. Similar results were reported by Oliveira et al. (2010), who observed that the higher P availability also promoted the growth of radish plants, regardless of the studied level of salinity. In addition, the levels of 60 and $100 \%$ of the $\mathrm{P}$ recommendation did not differ, possibly because of the low $\mathrm{P}$ concentrations existing in the soil of these treatments, which were not sufficient to promote satisfactory plant growth (Figure 2B).

For the number of leaves, there was significant interaction between the levels of irrigation water salinity and phosphate fertilization, so that plants cultivated with 60 and $100 \%$ of the $\mathrm{P}$ recommendation linearly reduced the number of leaves by 28.1 and $30.7 \%$ at the high salinity level $\left(4.5 \mathrm{dS} \mathrm{m}^{-1}\right)$ in relation to the control $\left(0.5 \mathrm{dS} \mathrm{m}^{-1}\right)$. Plants cultivated with $140 \%$ of the $\mathrm{P}$ recommendation showed mean production of 4.06 leaves per plant, at all salinity levels studied, which indicates the previous lack of salt stress on the leaf production of these plants (Figure 2D).

The reduction of growth in cowpea plants when subjected to salt stress can be related to the decrease in the water potential of the tissues caused by the excess of salts in the soil solution, leading to restrictions in the rates of cell elongation and division, which directly depend on the extensibility of the cell wall. Consequently, the failures occurring in the adjustment resulted in injuries similar to those caused by drought, such as loss of turgor and growth reduction (Silva 
et al., 2009; Sousa et al., 2011; Taiz and Zeiger, 2013). In addition, the low water content in the cells, caused by the restriction imposed by salts due to the soil salinity, promotes metabolic alterations and indirect effects, such as toxicity by specific ions, for example salts of sodium and chlorine (Munns and Tester, 2008; Syvertsen and Garcia-Sanchez, 2014). However, plants fertilized with higher P doses obtained greater growth in height and their number of leaves was not affected by salinity during the first 15 days of cultivation, indicating that the plants responded to phosphate fertilization even under saline conditions (Figure 2B and D).

A

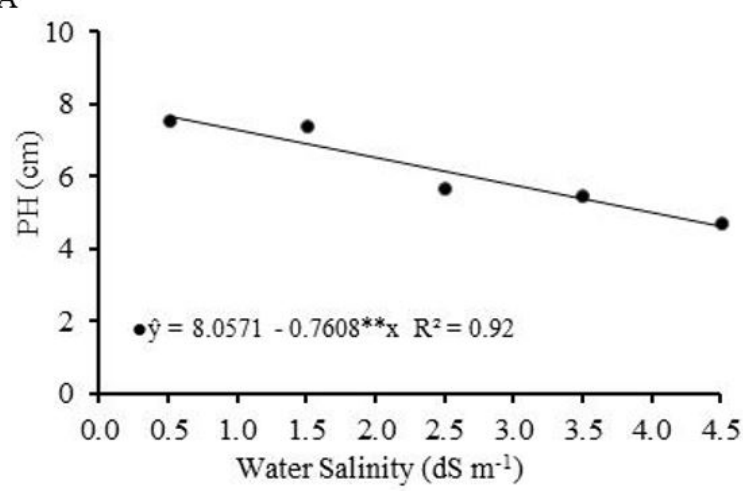

$\mathrm{C}$

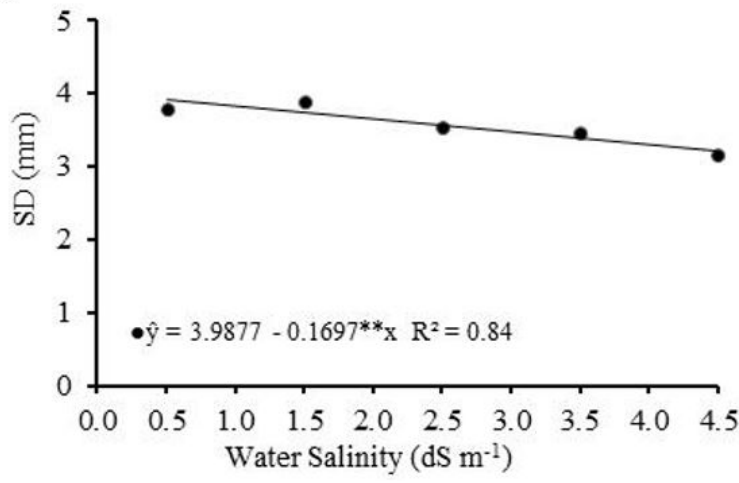

B

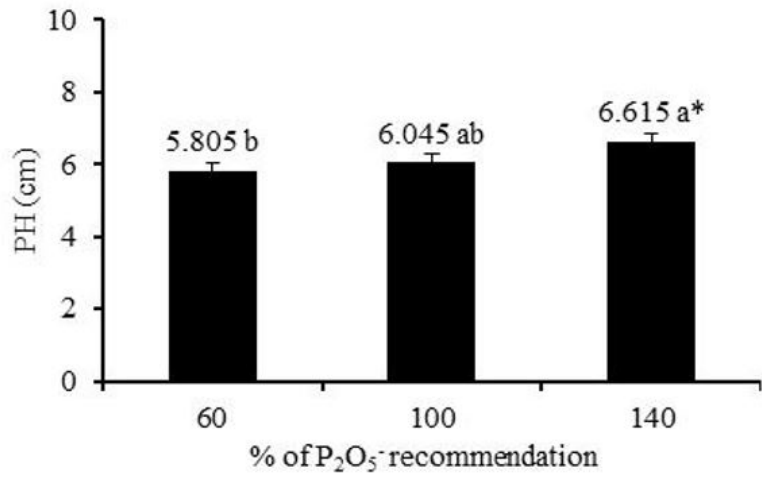

D

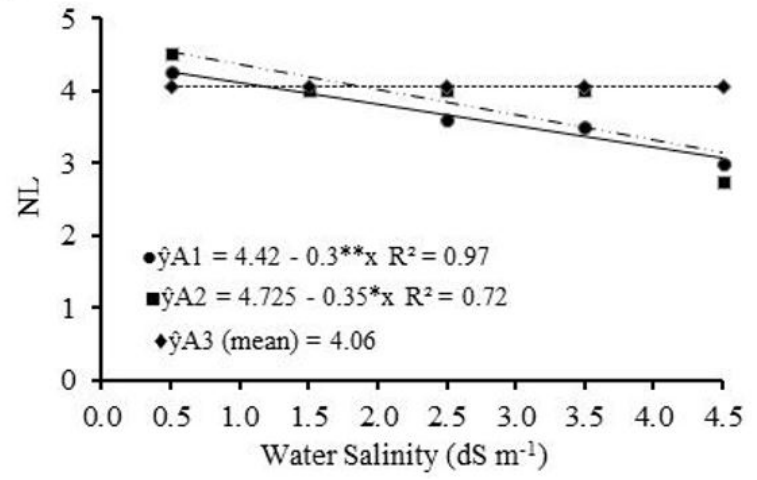

Figure 2. Plant height (PH) (A and B), stem diameter (SD) (C) and number of leaves (NL) (D) of cowpea, cv. Paulistinha, under different levels of water salinity and phosphate fertilization $\left(\mathrm{A} 1=60, \mathrm{~A} 2=100 \%\right.$ and $\mathrm{A} 3140 \%$ of the recommendation of $\mathrm{P}_{2} \mathrm{O}_{5}{ }^{-}$of $60 \mathrm{~kg} \mathrm{ha}^{-1}$ ), at 15 days after sowing.

Note: $*$ and $* *=$ significant at 5 and $1 \%$ probability $(\mathrm{p}<0.05$ and $\mathrm{p}<0.01)$. Equal letters do not differ from the Tukey test at the 5\% probability level.

Ferreira et al. (2007) observed that high soil salinity decreases the P contents in the tissue of maize plants, because the ionic force reduces the phosphate activity in the soil. Possibly, the addition of $\mathrm{P}$ beyond the recommendation promoted the higher availability of the nutrient, thus leading to better growth in relation to plants cultivated under the lowest doses.

StDM was influenced by water salinity, with linear reductions in the stem phytomass accumulation of $14.2 \%$ per dS m${ }^{-1}$ (Figure 3). According to Munns and Tester (2008), plant growth is restricted by both the water deficit induced by the high osmolarity of the solution and the ionic toxicity, involving metabolic and physiological damages, thus affecting the phytomass accumulation of the plant. 


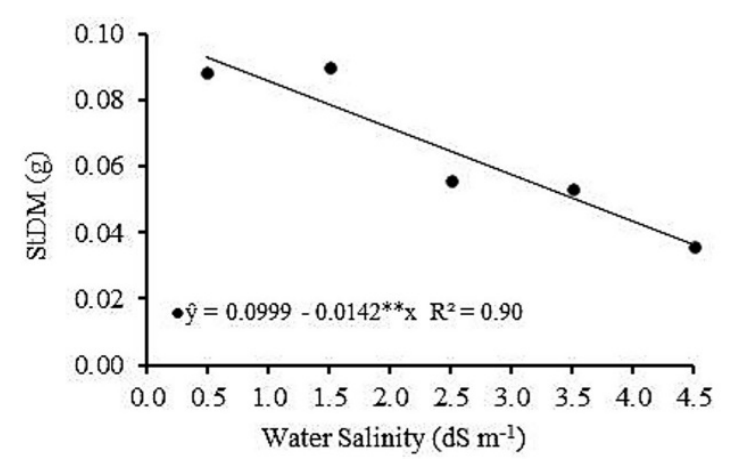

Figure 3. Stem dry matter (StDM) of cowpea plants, cv. Paulistinha, under different levels of irrigation water salinity and phosphate fertilization $(\mathrm{A} 1=60, \mathrm{~A} 2=100 \%$ and $\mathrm{A} 3$ $140 \%$ of the recommendation of $\mathrm{P}_{2} \mathrm{O}_{5}{ }^{-}$of 60 $\left.\mathrm{kg} \mathrm{ha}^{-1}\right)$, at 15 days after sowing.

Note: $* *=$ significant at 0.01 probability level $(\mathrm{p}<0.01)$.

For LDM and ShDM, as observed for StDM, there were linear reductions in the phytomass accumulation, as the irrigation water salinity increased, respectively to 0.062 and $0.76 \mathrm{~g}$ per $\mathrm{dS} \mathrm{m}^{-1}$ (Figure 4A and C). The observed behavior denotes the severity of the salt stress on cowpea plants, which affected the synthesis of carbohydrates and, consequently, biomass accumulation. However, plants cultivated in soil containing $140 \%$ of the recommended dose of P showed higher accumulations of LDM (on average, 25.5\%) and ShDM (on average, 19.2\%) in relation to the other treatments, indicating that under this condition the reduction in phytomass accumulation by the salt stress was attenuated (Figure 4B and D). Possibly, with the application of $\mathrm{P}$ in the form of single superphosphate, besides meeting the requirement of $\mathrm{P}$, the release of calcium sulfate favored the supply of calcium and sulfur.
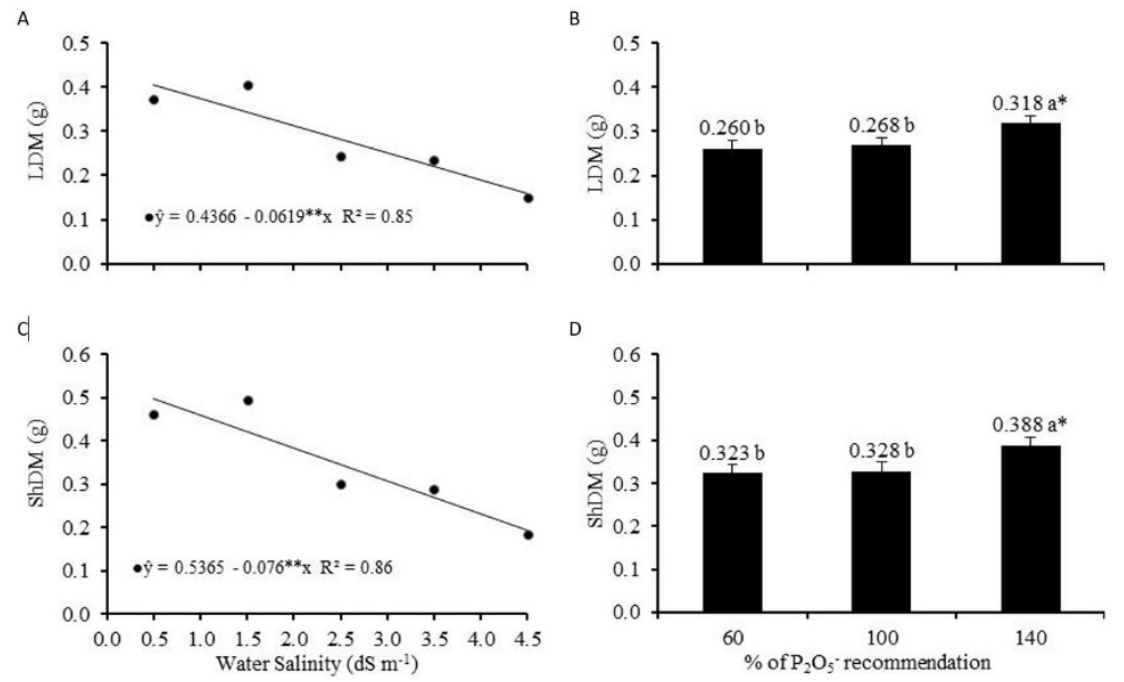

Figure 4. Leaf dry matter (LDM) (A and B) and shoot dry matter (ShDM) (C and D) of cowpea plants, cv. Paulistinha, under different levels of irrigation water salinity and phosphate fertilization $(\mathrm{A} 1=60$, $\mathrm{A} 2=100 \%$ and $\mathrm{A} 3140 \%$ of the recommendation of $\mathrm{P}_{2} \mathrm{O}_{5}{ }^{-}$of $60 \mathrm{~kg} \mathrm{ha}^{-1}$ ), at 15 days after sowing.

Note: $*$ and $* *=$ significant at 5 and $1 \%$ probability $(\mathrm{p}<0.05$ and $\mathrm{p}<0.01)$. Equal letters do not differ from the Tukey test at the $5 \%$ probability level. 


\section{CONCLUSIONS}

The increase in irrigation water salinity above $1.5 \mathrm{dSm}^{-1}$ reduced emergence, growth and dry matter accumulation of cowpea plants.

The increment of $40 \%$ in the recommendation of phosphate fertilization for the cowpea crop promoted increments in the growth and biomass accumulation of the shoots, regardless of the salinity level.

\section{ACKNOWLEDGMENTS}

To the Coordenação de Aperfeiçoamento de Pessoal de Nível Superior (CAPES) for granting the master's scholarship ( $1^{\text {st }}$ author), to the Instituto Nacional de Ciência e Tecnologia em Salinidade (INCTSal) for funding the research and to the Conselho Nacional de Desenvolvimento Científico e Tecnológico $(\mathrm{CNPq})$ for the research productivity $\left(5^{\text {th }}\right.$ and $6^{\text {th }}$ author) and scientific initiation scholarships ( $3^{\text {rd }}$ author $)$.

\section{REFERENCE}

BEZERRA, A. K. P.; LACERDA, C. F.; HERNANDEZ, F. F. F.; SILVA, F. B.; GHEYI, H. R. Rotação cultural feijão caupi/milho utilizando-se águas de salinidades diferentes. Ciência Rural, v.40, n.5, p.1075-1082, 2010. http://dx.doi.org/10.1590/S010384782010000500012

CAVAlCANTI, F. J. A.; SANTOS, J. C. P; PEREIRA, J. R.; LEITE, J. P.; SILVA, M. C. L.; FREIRE, F. J. et al. Recomendações de adubação para o Estado de Pernambuco. $2^{\text {a }}$ Aproximação. Recife: IPA, 2008. 212p.

COElho, J. B. M.; BARros, M. F. C.; BEZERRA NETO, E.; CORREA, M. M. Comportamento hídrico e crescimento do feijão vigna cultivado em solos salinizados. Revista Brasileira de Engenharia Agrícola e Ambiental, v.17, n.4, p.379-385, 2013. http://dx.doi.org/10.1590/S1415-43662013000400004

DANTAS, C. V. S.; SILVA, I. B.; PEREIRA, G. M.; MAIA, J. M.; LIMA, J. P. M. S.; MACEDO, C. E. C. Influência da salinidade e deficit hídrico na germinação de sementes de Carthamus tinctorius L. Revista Brasileira de Sementes, v.33, n.3, p.574-582, 2011. http://dx.doi.org/10.1590/S0101-31222011000300020

EMBRAPA. Centro Nacional de Pesquisa de Solos. Manual de métodos de análise do solo. 3. ed. Rio de Janeiro, 2011, 230 p. (Embrapa - CNPS. Documentos, 132).

FERREIRA, D. F. Sisvar: a computer statistical analysis system. Ciência e Agrotecnologia, v.35, v. 6, p.1039-1042, 2011. http://dx.doi.org/10.1590/S1413-70542011000600001

FERREIRA, P. A.; GARCIA, G. O.; NEVES, J. C. L.; MIRANDA, G. V.; SANTOS, D. B. Produção relativa do milho e teores folheares de nitrogênio, fósforo, enxofre e cloro em função da salinidade do solo. Revista Ciência Agronômica, v.38, n.1, p.7-16, 2007.

LOPES, A. S.; GUILHERME, L. R. G.; CUNHA, J. F. Superfosfatos simples e outros fertilizantes fosfatados solubilizados industrialmente via rota do ácido sulfúrico. São Paulo: Ed. Gráfica Nagy, 2010. 48 p. 
MEDEIROS, J. F.; SILVA, M. C. C.; SARMENTO, D. H. A.; BARROS, A. D. Crescimento do meloeiro cultivado sob diferentes níveis de salinidade, com e sem cobertura do solo. Revista Brasileira de Engenharia Agrícola e Ambiental, v.11, n.3, p.248-255, 2007. http://dx.doi.org/10.1590/S1415-43662007000300002

MESQUiTA, E. F.; SÁ, F. V. S.; BERTINO, A. M. P.; CAVALCANTE, L. F.; PAIVA, E. P.; FERREIRA, N. M. Effect of soil conditioners on the chemical attributes of a saline-sodic soil and on the initial growth of the castor bean plant. Semina: Ciências Agrárias, v.36, n.10, p.2527-2538, 2015. http://dx.doi.org/10.5433/1679-0359.2015v36n4p2527

MOUSINHO, F. E. P.; ANDRADE JR, A. S.; FRIZZONE, J. A. Viabilidade econômica do cultivo irrigado do feijão-caupi no Estado do Piauí. Acta Scientiarum Agronomy, v.30, n.1, p.139-145, 2008. http://dx.doi.org/10.4025/actasciagron.v30i1.1165

MUNNS, R.; TESTER, M. Mechanism of salinity tolerance. Annual Review of Plant Biology, v.59, n.6, p.651-681, 2008. http://dx.doi.org/10.1146/annurev.arplant.59.032607.092911

OLIVEIRA, F. R. A.; OLIVEIRA, F. A. O.; MEDEIROS, J. F.; SOUSA, V. F. L.; FREIRE, A. G. Interação entre salinidade e fósforo na cultura do rabanete. Revista Ciência Agronômica, v.41, n.1, p.519-526, 2010. http://dx.doi.org/10.1590/S180666902010000400003

PATEL, P. R.; KAJALII, S. S.; PATELI, V. R.; PATEL, V. J.; KHRISTIII, S. M. Impact of saline water stress on nutrient uptake and growth of cowpea. Brazilian Journal of Plant Physiology, v.22, n.1, p.43-48, 2010. http://dx.doi.org/10.1590/S167704202010000100005

ROCHA, M. M.; CARVALHO, K. J. M.; FREIRE FILHO, F. R.; LOPES, A. C. A.; GOMES, R. L. F.; SOUSA, I. S. Controle genético do comprimento do pedúnculo em feijão-caupi.

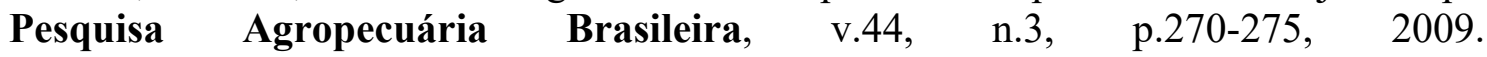
http://dx.doi.org/10.1590/S0100-204X2009000300008

SÁ, F. V. S.; ARAÚJO, J. L.; NOVAIS, M. C.; SILVA, A. P.; PEREIRA, F. H. F.; LOPES, K. P. Crescimento inicial de arbóreas nativas em solo salino-sódico do Nordeste brasileiro tratado com acondicionadores. Revista Ceres, v. 60, n.3, p. 388-396, 2013. http://dx.doi.org/10.1590/S0034-737X2013000300012

SÁ, F. V. S.; MESQUiTA, E. F.; BerTinO, A. M. P.; COSTA, J. D.; ARAÚJO, J. L. Influência do gesso e biofertilizante nos atributos químicos de um solo salino-sódico e no crescimento inicial do girassol. Irriga, v.20, n.1, p.46-59, 2015. http://dx.doi.org/10.15809/irriga.2015v20n1p46

SANTOS, D. R.; GATIBONI, L. C.; KAMINSKI, J. Fatores que afetam a disponibilidade do fósforo e o manejo da adubação fosfatada em solos sob sistema plantio direto. Ciência Rural, v. 38, n.2, p. 576-586, 2008. http://dx.doi.org/10.1590/S010384782008000200049

SCHUAB, S. R. P.; BRACCINI, A. L.; FRANÇA NETO, J. B.; SCAPIM, C. A.; MESCHEDE, D. K. Potencial fisiológico de sementes de soja e sua relação com a emergência das plântulas em campo. Acta Scientiarum. Agronomy, v.28, n.4, p.553-561, 2006.

SILVA, F. E. O.; MARACAJÁ, P. B.; MEDEIROS, J. F.; OLIVEIRA, F. A.; OLIVEIRA, M. K. T. Desenvolvimento vegetativo do feijão-Caupi irrigado com água salina em casa de vegetação. Revista Caatinga, v. 22, n.3, p. 156-159, 2009. 
SOUSA, A. E. C.; GHEYI, H. R.; CORREIA, K. G.; SOARES, F. A. L.; NOBRE, R. G. Crescimento e consumo hídrico de pinhão manso sob estresse salino e doses de fósforo. Revista Ciência Agronômica, v.42, n.2, p.310-318, 2011. http://dx.doi.org/10.1590/S1806-66902011000200008

SOUSA, F. Q.; ARAÚJO, J. L.; SILVA, A. P.; PEREIRA, F. H. F.; SANTOS, R. V.; LIMA, G. S. Crescimento e respostas fisiológicas de espécies arbóreas em solo salinizado tratado com acondicionadores. Revista Brasileira de Engenharia Agrícola e Ambiental, v.16, n.2, p. 173-181, 2012. http://dx.doi.org/10.1590/S1415-43662012000200007

SYVERTSEN, J. P.; GARCIA-SANCHEZ, F. Multiple abiotic stresses occurring with salinity stress in citrus. Environmental and Experimental Botany, v.103, n.6, p.128-137, 2014. http://dx.doi.org/10.1016/j.envexpbot.2013.09.015

TAIZ, L.; ZEIGER, E. Fisiologia vegetal. 5. ed. Porto Alegre: Artmed, 2013. 918p.

VOIGT, E. L.; ALMEIDA, T. D.; CHAGAS, R. M.; PONTE, L. F. A.; VIÉGAS, R. A.; SILVEIRA, J. A. G. Source-sink regulation of cotyledonary reserve mobilization during cashew (Anacardium occidentale) seedling establishment under $\mathrm{NaCl}$ salinity. Journal of Plant Physiology, v.166, n.1, p.80-89, 2009.

http://dx.doi.org/10.1016/j.jplph.2008.02.008 


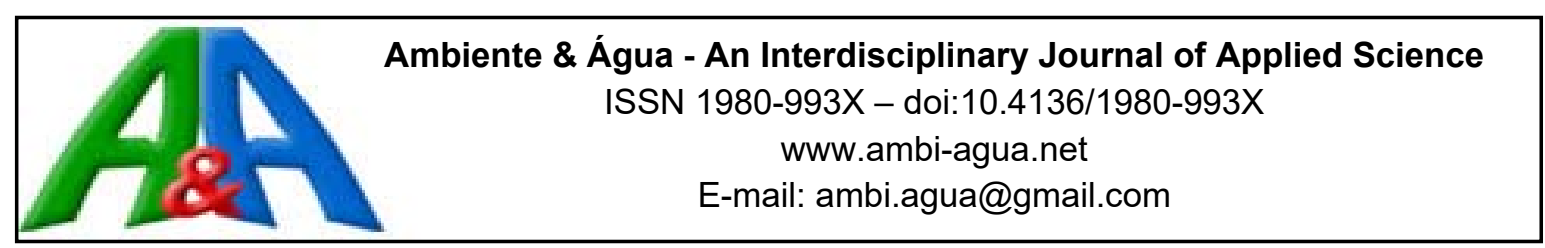

\title{
Utilização da estrutura de comunidades de macroinvertebrados bentônicos como indicador de qualidade da água em rios no sul do Brasil
}

\author{
doi:10.4136/ambi-agua.2015
}

Received: 27 Sep. 2016; Accepted: 06 Feb. 2017

\author{
Flávia Bernardo Chagas*; Camila Fatima Rutkoski; \\ Gregori Betiato Bieniek; Gean Delise Leal Pasquali Vargas; \\ Paulo Afonso Hartmann; Marilia Teresinha Hartmann \\ Universidade Federal da Fronteira Sul (UFFS), Erechim, RS, Brasil \\ Setor de Laboratórios \\ *Autor correspondente: e-mail: flavia_bio@uffs.edu.br, \\ camilarutkoski@hotmail.com,gbetiatobieniek@yahoo.com.br, \\ geandelise@uffs.edu.br, hartmann.paulo@uffs.edu.br, \\ marilia.hartmann@uffs.edu.br
}

\section{RESUMO}

Macroinvertebrados bentônicos são afetados pela alteração dos sistemas aquáticos, que diminuem ou aumentam sua população. $O$ conhecimento sobre macroinvertebrados bentônicos pode ser utilizado para conhecer a qualidade da água de lagos e rios, pois estes organismos respondem às variações nas condições ambientais. $\mathrm{O}$ objetivo deste estudo foi utilizar a estrutura de comunidades de macroinvertebrados como indicador de qualidade ambiental em dois rios de abastecimento público no município de Erechim, Estado do Rio Grande do Sul. As coletas foram realizadas mensalmente de novembro de 2014 até abril de 2015, utilizando-se amostrador tipo Surber. Para a avaliação das condições ambientais foi aplicado um protocolo de avaliação rápida (PAR). Foram identificados 4.096 macroinvertebrados, distribuídos em 41 táxons de Annelida, Nematoda, Crustacea, Aracnida e Insecta. Os dois rios apresentaram trechos com alteração antrópica nas margens e os ambientes mais alterados foram associados com a maior abundância do grupo trófico coletor-catador. Integrar o método de avaliação da diversidade de habitats com análises da comunidade bentônica pode ser um método eficiente para obtenção de parâmetros mais completos da qualidade da água e da degradação dos sistemas aquáticos.

Palavras-chave: ambientes aquáticos, estrutura trófica, protocolo de avaliação rápida.

\section{Use of benthic macroinvertebrate community as a water quality indicator in streams in Southern Brazil}

\begin{abstract}
Benthic macroinvertebrates are affected by changes in aquatic systems that can influence their population size and community structure. Because of this, knowledge about benthic macroinvertebrates fauna can be used as a water quality indicator in lakes and streams, since many of them are sensitive to environmental disturbances. This study sought to evaluate the
\end{abstract}


use of the benthic macroinvertebrate community as a water quality indicator in two streams in Southern Brazil. The streams were sampled monthly from November 2014 to April 2015. The macroinvertebrate collections were made with a Surber sampler. Environment heterogeneity was evaluated using the protocol for rapid assessment of habitat diversity (RAP). A total of 4096 benthic macroinvertebrates was recorded, distributed among 41 taxa of the Annelida, Nematoda, Crustacea, Arachnida and Insecta. The two rivers showed antropic influence on their banks, and the more affected sites were associated with a higher abundance of the collectors-gatherers. The taxon diversity was determined by the environmental heterogeneity and the trophic structure of the community seems to be influenced by the presence of organic matter and nutrients. The use of the RAP integrated with knowledge of the benthic macroinvertebrates communities can be an efficient tool to evaluate water quality and the parameters of degradation in aquatic systems.

Keywords: aquatic environments, rapid assessment protocol, trophic structure.

\section{INTRODUÇÃO}

Macroinvertebrados bentônicos compreendem invertebrados com tamanho de 2 a $5 \mathrm{~mm}$, que habitam ou passam pelo menos parte do ciclo de vida nos substratos de fundo de corpos de águas continentais (Mugnai et al., 2010). Os principais grupos de invertebrados bentônicos são insetos, anelídeos, moluscos e crustáceos (Tundisi e Matsumura-Tundisi, 2008). A distribuição destes macroinvertebrados é influenciada por diversos fatores ambientais (Barbola et al., 2011) e alimentação (Merritt e Cummins, 1996; Mugnai et al., 2010). Estas informações são usadas para entender fatores que influenciam a estrutura da comunidade de rios (König et al., 2008; Giuliatti e Carvalho, 2009; Hepp e Santos, 2009; Hepp et al., 2010).

Os organismos bentônicos são diretamente afetados pela alteração na composição natural dos sistemas aquáticos, que diminuem ou aumentam sua população (Marques e Barbosa, 2001; Hepp e Restello, 2007). A composição qualitativa de fauna bentônica é um bom indicador das condições ambientais de rios e lagos, por exemplo, na composição de Chironomidae, porque estes resistem a baixas concentrações de oxigênio dissolvido, fato que já foi observado em rios próximos aos deste estudo (König et al., 2008). Espécies de macroinvertebrados bentônicos dos grupos Ephemeroptera, Plecoptera e Trichoptera podem ser indicadoras de ambientes de baixo impacto antrópico (Dohet et al., 2002; Hepp e Restello, 2007).

A divisão dos grupos funcionais de alimentação foi descrita por Merritt e Cummins (1996). O emprego de grupos tróficos funcionais e o conhecimento de como os organismos colonizam os habitats compõem uma ferramenta útil para a conservação dos recursos hídricos, pois pode ser usado como base para políticas e propostas de conservação e manutenção dos recursos naturais de uma determinada área (Callisto et al., 2001; König et al., 2008; Batista et al., 2010). Ao longo da extensão de um rio é possível verificar diferenças na estrutura das comunidades bentônicas resultantes das alterações dos fatores físicos e da disponibilidade de nutrientes (Vannote et al., 1980; Hepp et al., 2010).

Os macroinvertebrados aquáticos são importantes no fluxo de energia de um corpo hídrico, pois constituem a maior fonte de alimento para outros organismos, como peixes e outros insetos (Rosenberg e Resh, 1993). Além disso, fazem parte da ciclagem de nutrientes, e tornam possível o transporte de matéria orgânica pelo rio, podendo esta ser utilizada por organismos filtradores, coletores e também pelos predadores (Vannote et al., 1980).

Nesse contexto, o objetivo deste estudo foi utilizar a estrutura de comunidades de macroinvertebrados como indicador de qualidade ambiental em dois rios de abastecimento público no município de Erechim, Estado do Rio Grande do Sul. 


\section{MATERIAL E MÉTODOS}

\section{1. Área de estudo}

O estudo foi realizado em dois rios utilizados para abastecimento público no município de Erechim, no norte do Estado do Rio Grande do Sul. Os Rios Leãozinho e Ligeirinho são a principal fonte de abastecimento de água para o município (barragem da Companhia Riograndense de Saneamento - CORSAN). Os Rios Leãozinho e Ligeirinho são tributários do arroio Tigre e pertencem a Área de Proteção Ambiental (APA) dos Rios Tigre e leãozinho, localizada entre as coordenadas geográficas $27^{\circ} 39^{\prime} 38,3^{\prime \prime}$ a $27^{\circ} 42^{\prime} 48,6^{\prime \prime} \mathrm{S}$ e $52^{\circ} 1415^{\prime \prime}$ a $52^{\circ} 17^{\prime}$ $23 " \mathrm{~W}$.

\subsection{Coleta de dados}

As coletas foram realizadas mensalmente no período de novembro de 2014 a abril de 2015 . Foram selecionados oito locais nos Rios Leãozinho e Ligeirinho, sendo quatro em cada rio. Selecionamos pontos com características equivalentes nos dois rios: próximo a nascente ponto 1, (Rio Leãozinho: $27^{\circ} 39^{\prime} 58^{\prime \prime} \mathrm{S} / 052^{\circ} 16^{\prime} 35^{\prime \prime} \mathrm{W}$; Rio Ligeirinho: $27^{\circ} 42^{\prime} 3^{\prime \prime} \mathrm{S} / 052^{\circ} 16^{\prime} 53^{\prime \prime}$ $\mathrm{W}$ ); meio do rio (considerado entre a nascente analisada e a entrada do reservatório de abastecimento) - ponto 2 (Rio Leãozinho: $27^{\circ} 40^{\prime} 18^{\prime \prime} \mathrm{S} / 052^{\circ} 15^{\prime} 55^{\prime \prime} \mathrm{W}$; Rio Ligeirinho: $27^{\circ} 41^{\prime} 55^{\prime \prime} \mathrm{S} / 052^{\circ} 16^{\prime} 12^{\prime \prime} \mathrm{W}$ ) e ponto 3 (Rio Leãozinho: $27^{\circ} 40^{\prime} 15^{\prime \prime} \mathrm{S} / 052^{\circ} 14^{\prime} 54^{\prime \prime} \mathrm{W}$; Rio Ligeirinho: $\left.27^{\circ} 41^{\prime} 48^{\prime \prime} \mathrm{S} / 052^{\circ} 15^{\prime} 50^{\prime \prime} \mathrm{W}\right)$, e próximo a entrada do reservatório para abastecimento - ponto 4 (Rio Leãozinho: 27 $40^{\prime} 18^{\prime \prime}$ S/ 52 $14^{\prime} 59^{\prime \prime}$ W; Rio Ligeirinho: $\left.27^{\circ} 40^{\prime} 58^{\prime \prime} \mathrm{S} / 052^{\circ} 14^{\prime} 41^{\prime \prime} \mathrm{W}\right)$. Em cada ponto foram realizadas três amostragens seguidas, no mesmo dia, uma vez por mês, totalizando 144 amostragens no período do estudo.

Para a avaliação das condições ambientais foi aplicado o Protocolo de Avaliação Rápida (PAR) da diversidade de habitats para trechos de bacias hidrográficas (ver Callisto et al. 2002). Este protocolo avalia um conjunto de parâmetros atribuindo pontuação com base na observação das condições do hábitat. O valor final do protocolo de avaliação é obtido a partir do somatório dos valores atribuídos a cada parâmetro independentemente. O protocolo indica condições de habitat e ambientais dos pontos analisados, determinando locais "impactados" (pontos: 0 a 40), "alterados" (pontos: 41 a 60) e "naturais" (pontos: acima de 61).

A coleta dos macroinvertebrados bentônicos foi realizada com um amostrador do tipo Surber (malha de $250 \mu \mathrm{m}$ e área de $0,1 \mathrm{~m}^{2}$ ). Os indivíduos foram acondicionados em frascos etiquetados contendo álcool $70 \%$. Os organismos foram triados sob estereomicroscópio de aumento de até 45 vezes. Os macroinvertebrados bentônicos foram identificados sempre que possível ao nível taxonômico de família, utilizando-se o Manual de Identificação de Macroinvertebrados Aquáticos do Estado do Rio de Janeiro (Mugnai et al., 2010).

Os macroinvertebrados foram classificados em cinco categorias tróficas (ver Merritt e Cummins, 1996): (1) coletores-catadores - alimentam-se de pequenas partículas de matéria orgânica por coleta nos depósitos de sedimento; (2) coletores-filtradores - capturam, por filtração, pequenas partículas de matéria orgânica em suspensão na coluna d'água; (3) fragmentadores - alimentam-se de folhas ou tecido de planta vascular vivo ou escavam madeira; (4) predadores - engolem a presa inteira ou ingerem os fluidos do tecido corporal; (5) raspadores - adaptados a raspar superfícies duras, alimentam-se de algas, bactérias, fungos e matéria orgânica morta adsorvidos aos substratos.

\subsection{Análises}

Foram estimados os valores de abundância, riqueza taxonômica, frequência de indivíduos nas amostras (considerados frequentes quando presentes em $50 \%$ ou mais das amostras (Dajoz, 2005) e calculadas a abundância total, índice de diversidade de Shannon-Wiener; índice de 
equitabilidade de Pielou e dominância Berger-Parker, por ponto amostral. Foi calculada também a abundância relativa de Ephemeroptera, Plecoptera e Trichoptera (EPT), pois estes grupos apresentam gêneros mais sensíveis às perturbações ambientais. Para avaliar se as diferenças foram significativas foi utilizado o teste não paramétrico de Mann-Whitney. Os resultados dos índices de estrutura bentônica foram correlacionados entre si e com os resultados do protocolo de avaliação rápida por meio de correlações múltiplas, utilizando o coeficiente de Pearson. As análises estatísticas foram processadas por meio do programa Statistica versão 8.0 e os cálculos dos índices biológicos com o programa DIVES.

\section{RESULTADOS E DISCUSSÃO}

Foram registrados 4.096 organismos bentônicos, pertencentes a 41 táxons de Annelida, Nematoda, Crustacea, Aracnida e Insecta, sendo este último o grupo mais representativo (Tabela 1). As ordens mais abundantes foram Trichoptera (Rio Leãozinho $n=760$; Rio Ligeirinho $n=800$ ), Diptera (Rio Leãozinho $n=738$; Rio Ligeirinho $n=287$ ) e Ephemeroptera (Rio Leãozinho $\mathrm{n}=451$; Rio Ligeirinho $\mathrm{n}=384$ ). As famílias mais abundantes foram Chironomidae (21\%) da ordem Diptera e Hydropsichidae (15\%) da ordem Trichoptera. A bacia do Rio Leãozinho apresentou maior abundância com 2244 organismos coletados, distribuídos em 37 táxons (Tabela 1).

Tabela 1. Macroinvertebrados bentônicos e sua classificação trófica. Rios Leãozinho e Ligeirinho, município de Erechim, Norte do Estado do Rio Grande do Sul.

\begin{tabular}{lccc}
\hline \multicolumn{1}{c}{ Táxons } & Rio Leãozinho & Rio Ligeirinho & Classificação trófica \\
\hline Annelida & 21 & 3 & Coletor-catador \\
Oligochaeta & 2 & 0 & Coletor-catador \\
Nematoda & & & \\
Arthropoda & & & \\
Crustacea & 30 & 18 & Coletor-catador \\
Aeglidae & 0 & 1 & Coletor-catador \\
Hyalellidae & 15 & 160 & Coletor-catador \\
Talitridae & & & \\
Aracnida & 4 & 2 & Predador \\
Acarina & & & \\
Insecta & & & Predador \\
Coleoptera & 6 & 3 & Raspador \\
Dytiscidae & 125 & 94 & Raspador \\
Elmidae & 1 & 1 & Fragmentador \\
Hydrophilidae & 9 & 8 & \\
Psephenidae & 1 & 0 & \\
Ptylodactilidae & & 2 & Raspador \\
Diptera & 0 & & \\
Blephariceridae & & & \\
Ceratopogonidade & & & \\
\hline Continua... & & & \\
\hline
\end{tabular}




\begin{tabular}{|c|c|c|c|}
\hline \multicolumn{4}{|l|}{ Continuação... } \\
\hline Chironomidae & 675 & 226 & Coletor-catador \\
\hline Culicidae & 1 & 1 & Coletor-catador \\
\hline Simuliidae & 54 & 56 & Coletor-filtrador \\
\hline \multicolumn{4}{|l|}{ Ephemeroptera } \\
\hline Baetidae & 96 & 136 & Coletor-catador \\
\hline Caenidae & 32 & 32 & Coletor-catador \\
\hline Leptohyphidae & 136 & 85 & Coletor-catador \\
\hline Leptophlebiidae & 186 & 130 & Raspador \\
\hline Oligoneuriidae & 1 & 1 & Coletor-catador \\
\hline \multicolumn{4}{|l|}{ Hemiptera } \\
\hline Gerridae & 1 & 0 & Predador \\
\hline Helotrephidae & 2 & 0 & Predador \\
\hline Naucoridae & 8 & 0 & Predador \\
\hline Veliidae & 0 & 1 & Predador \\
\hline \multicolumn{4}{|l|}{ Lepidoptera } \\
\hline Pyralidae & 1 & 0 & Fragmentador \\
\hline \multicolumn{4}{|l|}{ Odonata } \\
\hline Aeshnidae & 3 & 1 & Predador \\
\hline Calopterygidae & 4 & 1 & Predador \\
\hline Gomphidae & 1 & 0 & Predador \\
\hline Libellulidae & 6 & 16 & Predador \\
\hline Megapodagrionidae & 23 & 3 & Predador \\
\hline \multicolumn{4}{|l|}{ Plecoptera } \\
\hline Gripopterygidae & 30 & 66 & Fragmentador \\
\hline Perlidae & 2 & 3 & Predador \\
\hline \multicolumn{4}{|l|}{ Trichoptera } \\
\hline Anomalopsychidae & 4 & 1 & Raspador \\
\hline Glossosomatidae & 0 & 22 & Raspador \\
\hline Hydrobiosidae & 273 & 311 & Predador \\
\hline Hydroptilidae & 4 & 3 & Raspador \\
\hline Hydropsychidae & 273 & 339 & Coletor-filtrador \\
\hline Leptoceridae & 36 & 37 & Predador \\
\hline Odontoceridae & 141 & 76 & Fragmentador \\
\hline Philopotamidae & 18 & 0 & Coletor-catador \\
\hline Xyphocentronidae & 11 & 11 & Coletor-catador \\
\hline Abundância total & 2.244 & 1.852 & 4.096 \\
\hline
\end{tabular}

No Rio Leãozinho 10 táxons foram frequentes, sendo eles Chironomidae (95\%), Leptophlebiidae (95\%), Hydropsychidae (91\%), Hydrobiosidae (79\%), Elmidae (87\%), Baetidae (83\%), Leptohyphidae (70\%), Simuliidae (66\%), Megapodagrionidae (58\%) e 
Odontoceridae (54\%). No Rio Ligeirinho nove táxons foram frequentes: Hydropsychidae (87\%), Chironomidae (83\%), Hydrobiosidae (70\%), Baetidae (62\%), Elmidae (66\%), Leptophlebiidae (66\%), Gripopterygidae (58\%), Simuliidae (54\%) e Leptohyphidae (54\%).

Macroinvertebrados coletores-catadores (como os Chironomidae e os Baetidae) estão entre os mais frequente nos Rios Leãozinho e Ligeirinho (Tabela 2). Chironomidae normalmente é numericamente dominante em ambientes dulciaquícolas nas diferentes regiões climáticas (Suriano e Fonseca-Gessmer, 2004). Altas densidades destes gêneros podem evidenciar elevado teor de matéria orgânica no ambiente, o que os tornam eficientes indicadores de degradação ambiental (König et al., 2008; Hepp et al., 2010; Barbola et al., 2011). Devido a presença de grande quantidade de grupos tolerantes a poluição, como Chironomidae, outro estudo realizado na mesma região considerou a qualidade da água dos rios como insatisfatória (König et al., 2008).

Os predadores tiveram a segunda maior presença e riqueza de táxons nos Rios Leãozinho e Ligeirinho, devido ao predomínio da família Hydrobiosidae. Segundo Giuliatti e Carvalho (2009), os predadores alimentam-se de pedaços ou de presas inteiras de todos os grupos funcionais, não refletindo diretamente a influência do alimento de origem externa no ecossistema lótico.

Tabela 2. Proporção (\%) das categorias trófica dos macroinvertebrados nos pontos amostrais e totais nos Rios Leãozinho e Ligeirinho, município de Erechim, Norte do Estado do Rio Grande do Sul.

\begin{tabular}{|c|c|c|c|c|c|c|c|c|c|c|}
\hline & \multicolumn{5}{|c|}{ Rio Leãozinho } & \multicolumn{5}{|c|}{ Rio Ligeirinho } \\
\hline & $\mathrm{P} 1$ & $\mathrm{P} 2$ & P3 & $\mathrm{P} 4$ & Total & $\mathrm{P} 1$ & $\mathrm{P} 2$ & P3 & $\mathrm{P} 4$ & Total \\
\hline Fragmentadores & 3 & 8 & 8 & 11 & 8 & 2 & 10 & 11 & 9 & 9 \\
\hline Raspadores & 32 & 19 & 8 & 11 & 14 & 7 & 9 & 17 & 32 & 14 \\
\hline $\begin{array}{l}\text { Coletores- } \\
\text { filtradores }\end{array}$ & 18 & 8 & 18 & 11 & 15 & 12 & 28 & 22 & 25 & 21 \\
\hline $\begin{array}{l}\text { Coletores- } \\
\text { catadores }\end{array}$ & 30 & 53 & 48 & 47 & 46 & 57 & 27 & 32 & 26 & 36 \\
\hline Predadores & 17 & 12 & 18 & 15 & 17 & 22 & 26 & 18 & 8 & 20 \\
\hline
\end{tabular}

As pontuações das condições ambientais pelo Protocolo de Avaliação Rápida (PAR) foram de 60 a 68 pontos no Rio Leãozinho, e de 49 a 72 pontos no Rio Ligeirinho (Tabela 3). Os pontos 1 e 3 do Rio Leãozinho e o ponto 4 do Rio Ligeirinho foram classificados como natural no PAR. No entanto, foram observadas alterações ambientais nas margens dos rios, como redução da mata ciliar, culturas agrícolas, prática de pecuária, acúmulo de lixo e proximidade ao perímetro urbano. Essas alterações já tinham sido citadas para rios próximos, como a retirada da vegetação ciliar e a implementação de culturas ao longo das margens (König et al., 2008). Foram encontrados 1.243 exemplares dos grupos EPT no Rio Leãozinho e 1.253 exemplares no Rio Ligeirinho, correspondendo respectivamente a $55 \%$ e $67 \%$ do total de indivíduos dos rios. A ordem Trichoptera foi a mais abundante, tanto para o número de indivíduos quanto para táxons (Rio Leãozinho $n=9$; Rio Ligeirinho $n=9$ ). $O$ ponto 3 do Rio Leãozinho e ponto 3 do Rio Ligeirinho apresentaram maior porcentagem de macroinvertebrados das ordens EPT (19\% e $26 \%$ do total de indivíduos coletados; Tabela 3). Os pontos classificados como naturais pelo PAR não representam os pontos com maiores valores de EPT (Tabela 3 ).

Os Ephemeroptera, Plecoptera e Trichoptera (EPT), compõem um rico conjunto de táxons que ocorrem em córregos de baixa e média ordem. Vários fatores podem influenciar a distribuição de EPT, entre eles, os tipos de substratos (Silveira et al., 2006), a heterogeneidade de habitats, além da velocidade de correnteza e a disponibilidade de recursos tróficos (Crisci-Bispo et al., 2007; Hepp e Santos, 2009). Nos Rios Leãozinho e Ligeirinho foi observada maior abundância de macroinvertebrados das ordens EPT em trechos com 
corredeiras com a largura igual à do rio (ponto 3 dos Rios Leãozinho e Ligeirinho) e com substrato pedregoso no leito dos rios (de acordo com itens analisados no PAR; detalhes do protocolo em Callisto et al. 2002).

Tabela 3. Valores de EPT (\%), Diversidade (H'), Equitabilidade, Dominância, Riqueza absoluta e pontuação e classificação pelo Protocolo de Avaliação Rápida (PAR), nos pontos amostrais dos Rios Leãozinho e Ligeirinho, município de Erechim, Norte do Estado do Rio Grande do Sul. N = Natural; A = Alterado; (pontuação PAR).

\begin{tabular}{|c|c|c|c|c|c|c|c|c|}
\hline & \multicolumn{4}{|c|}{ Rio Leãozinho } & \multicolumn{4}{|c|}{ Rio Ligeirinho } \\
\hline & $\mathrm{P} 1$ & $\mathrm{P} 2$ & P3 & P4 & P1 & $\mathrm{P} 2$ & P3 & $\mathrm{P} 4$ \\
\hline EPT & $7 \%$ & $13 \%$ & $19 \%$ & $15 \%$ & $11 \%$ & $21 \%$ & $26 \%$ & $8 \%$ \\
\hline Diversidade $\left(\mathrm{H}^{\prime}\right)$ & 1,009 & 1,113 & 0,917 & 0,967 & 0,904 & 0,986 & 1,025 & 1,055 \\
\hline Equitabilidade & 0,789 & 0,769 & 0,674 & 0,732 & 0,684 & 0,724 & 0,788 & 0,825 \\
\hline Dominância & 0,172 & 0,249 & 0,359 & 0,340 & 0,320 & 0,259 & 0,189 & 0,151 \\
\hline Riqueza & 19 & 28 & 23 & 21 & 21 & 23 & 20 & 19 \\
\hline PAR & $\mathrm{N}(68)$ & $\mathrm{A}(60)$ & $\mathrm{N}(65)$ & $\mathrm{A}(60)$ & A (49) & A (57) & $\mathrm{A}(60)$ & $\mathrm{N}(72)$ \\
\hline
\end{tabular}

O grupo coletor catador dominou as amostras (Tabela 2). Essa categoria se alimenta de matéria orgânica, o que mostra a grande importância da matéria orgânica como recurso alimentar na dieta dos macroinvertebrados analisados (Giuliatti e Carvalho, 2009). Esse grupo não teve forte correlação com os resultados do PAR (-0,57), mas é possível verificar que os pontos que tiveram maior pontuação no PAR (P1 do Rio Leãozinho e P4 do Rio Ligeirinho) apresentaram as menores porcentagens de catadores-coletores, significando que nos ambientes naturais a representatividade desse grupo diminuiu. $\mathrm{O}$ contrário também ocorreu pois o ponto com menor pontuação no PAR (49) foi exatamente o local com maior porcentagem do grupo coletor catador (57\%). É possível inferir que neste estudo os coletores catadores tiveram maior afinidade com áreas alteradas, embora somente maiores estudos poderiam confirmar esse fato.

A porcentagem de coletores-filtradores foi negativamente correlacionada com coletores catadores nos pontos amostrados $(-0,87)$. Isso significa que foram encontrados mais coletores filtradores em locais que tinham menor número de coletores catadores. Os outros grupos não tiveram correlação significativa entre si.

O grupo raspador foi o único que apresentou correlação clara com os resultados do PAR $(0,77)$. Dos três pontos classificados como natural pelo PAR, dois (ponto 1 do Rio Leãozinho e 4 do Rio Ligeirinho) apresentaram maior proporção de raspadores (ambos 32\%; Tabelas 2 e 3). Os raspadores, como Leptophlebiidae e Elmidae, tiveram abundância reduzida nos demais pontos amostrais, indicando baixa quantidade do litter cedido pela vegetação ripária (pobre), que é a principal fonte de alimento para esses dois táxons (Batista et al., 2010). A maior proporção nos pontos considerados naturais e baixa proporção nos considerados alterados parecerem indicar que os raspadores servem como fortes indicadores da qualidade ambiental nos corpos hídricos estudados.

O ponto 2 do Rio Leãozinho apresentou o maior índice de diversidade $\mathrm{H}^{\prime}=1,113$. A maior equitabilidade foi observada no ponto 1 do Rio Leãozinho $(0,789)$ e no ponto 4 do Rio Ligeirinho (0,825). A maior dominância de espécies foi obtida no ponto 3 do Rio Leãozinho $(0,359)$ e no ponto 1 do Rio Ligeirinho $(0,320)$. O Rio Leãozinho apresentou maior riqueza de táxons no ponto 2 (28 táxons), os menores resultados foram registrados no ponto 1 do Rio Leãozinho (19 táxons) e ponto 4 do Rio Ligeirinho (19 táxons; Tabela 3). Os valores de

Rev. Ambient. Água vol. 12 n. 3 Taubaté - May / Jun. 2017 
abundância não apresentaram diferenças significativas $(p=0,06 ; U=200)$ entre os rios. A riqueza taxonômica dos organismos entre os rios apresentou diferença significativa $(p=0,02$, $\mathrm{U}=179$ ).

Variáveis biológicas como diversidade e equitabilidade podem ser utilizadas como parâmetro de qualidade das águas, e neste sentido, valores elevados de riqueza, diversidade e equitabilidade indicam boa qualidade de água (Hepp e Restello, 2007). No presente estudo, os valores destes parâmetros podem ser considerados altos (Tabela 3), indicando qualidade de água boa. Percebe-se também que os dois rios são semelhantes nestas variáveis, pois ao comparar os rios por resultados dos índices de estrutura da comunidade bentônica, não houve diferença significativa entre diversidade, equitabilidade, dominância e riqueza $(p>0,05)$. A quantificação do PAR também concordou com os índices de estrutura bentônica, pois não teve diferença significativa entre eles. $(p>0,05)$. A equitabilidade apresentou correlação de Pearson positiva com a diversidade $(r=0,81)$ e negativa com a dominância $(r=-0,92) \operatorname{com} p<0,05$. A dominância entre os táxons se correlacionou positivamente com a abundância total $(r=0,75)$.

Os resultados obtidos por meio da equitabilidade podem ser explicados através da correlação positiva com a diversidade e negativa com a dominância. Assim, pontos com maiores resultados de diversidade e menores resultados de dominância tendem a apresentar grupos igualmente abundantes. Considerando a dominância entre táxons, pode-se inferir que o ponto 3 do Rio Leãozinho e o ponto 1 do Rio Ligeirinho, onde foi registrada a menor equitabilidade e a maior abundância de macroinvertebrados, também apresentaram maior dominância. Resultados menores de equidade na distribuição da comunidade se devem a dominância de Chironomidae, Hydrobiosidae e Hydropsychidae ao se comparar com a abundância dos demais táxons. O índice de diversidade também foi menor nestes pontos.

Pela análise do PAR foi possível perceber que os Rios Leãozinho e Ligeirinho apresentaram trechos com alteração antrópica nas margens dos rios, como ausência de mata ciliar, culturas agrícolas, prática de pecuária, acúmulo de lixo e proximidade ao perímetro urbano, inclusive na nascente dos rios. Essa perturbação urbana é comum nos rios da região (Biasi et al., 2010), o que torna o fato preocupante.

\section{CONCLUSÃO}

Seria esperado que os rios amostrados tivessem nascentes com condições ambientais de alta diversidade de macroinvertebrados e grupos tróficos ligados a este ambiente. No entanto, a condição ambiental mostrada pelo PAR mostrou uma nascente natural e outra alterada, e ao longo do rio essa condição foi se alternando, provavelmente de acordo com o uso da terra no entorno. A diversidade em si dos macroinvertebrados encontrados não teve relação com a qualidade ambiental, mas sim com as diferentes características dos grupos funcionais encontrados, como mostrou a abundância de diferentes grupos com locais mais ou menos alterados.

A avaliação pelo protocolo proposto por Callisto et al. (2002) permitiu relacionar ambientes alterados com a maior abundância do grupo trófico coletor-catador. Da mesma forma, pontos com maior qualidade foram associados com maior proporção de raspadores.

Os resultados dos índices de estrutura da comunidade bentônica mostraram diminuição na qualidade ambiental dos rios, dada à representatividade de famílias dominantes e tolerantes a poluição moderada. Os grupos de Ephemeroptera, Plecoptera e Trichoptera foram representativos nos trechos dos Rios Leãozinho e Ligeirinho relacionados a ambientes com correnteza e substrato rochoso. A estrutura trófica da comunidade de macroinvertebrados parece sofrer influência da disponibilidade de matéria orgânica e de nutrientes.

O uso do protocolo de avaliação rápida como o protocolo desenvolvido por Callisto et al. (2002) é uma importante ferramenta no desenvolvimento de programas de monitoramento 
ecológico e na restauração de ambientes lóticos. Os resultados obtidos por meio do protocolo de avaliação rápida podem ser reforçados e/ou ajustados em função de informações sobre estrutura das comunidades de macroinvertebrados bentônicos. Integrar o método de avaliação da diversidade de habitats com análises da comunidade bentônica pode ser utilizado para obtenção de parâmetros mais completos da estrutura e qualidade de corpos hídricos, especialmente naqueles utilizados para abastecimento público, pois necessitam de uma boa qualidade de água para que o tratamento convencional de água seja efetivo. Neste sentido estudos como este são importantes para compreender melhor como monitorar a qualidade de água nos rios, sem recorrer sempre aos parâmetros físicos químicos.

\section{REFERÊNCIAS}

BARBOLA, I. F.; MORAES, M. F. P. G.; ANAZAWA, T. M.; NASCIMENTO, E. A.; SEPKA, E. R.; POLEGATTO, C. M. et al. Avaliação da comunidade de macroinvertebrados aquáticos como ferramenta para o monitoramento de um reservatório na bacia do Rio Pitangui, Paraná, Brasil. Iheringia, Série Zoologia, v. 101, n. 2, p. 15-23, 2011. http://producao.usp.br/handle/BDPI/6782

BATISTA, H. U.; BARBOLA, I. F.; KLOTH, A. E. G.; MILLÉO, J. Estrutura e composição da fauna de macroinvertebrados como forma de avaliação da qualidade da água do rio Verde, em Ponta Grossa, Paraná, Brasil. Terr@Plural, v. 4, n. 2, p. 241-256, 2010.

BIASI, C.; KÖNIG, R.; MENDES, V.; TONIN, A. M.; SENSOLO, D.; SOBCZAK, J. R. C. et al. Biomonitoramento das águas pelo uso de macroinvertebrados bentônicos: oito anos de estudos em riachos da região Alto Uruguai. Perspectiva, v. 34, n. 125, p. 67 - 77, 2010.

CALlisto, M.; FERREIRA, W. R.; MORENO, P.; GOULART, M.; PETRUCIO, M. Aplicação de um protocolo de avaliação rápida diversidade de habitats em atividades de ensino e pesquisa (MG-RJ). Acta Limnologica Brasileira, v. 14, n. 1, p. 91-98, 2002.

CALliSTO, M.; MORETTI, M.; GOULART, M. Macroinvertebrados Bentônicos como Ferramenta para Avaliar a Saúde de Rios. Revista Brasileira de Recursos Hídricos, v. 6, n. 1, p. 71-82, 2001.

CRISCI-BISPO, V. L.; BISPO, P. C.; FROEHLICH, C. G. Ephemeroptera, Plecoptera and Trichoptera assemblages in two Atlantic Rainforest streams, Southeastern Brazil. Revista Brasileira de Zoologia, v. 24, n. 2, p. 312-318, 2007. http://dx.doi.org/10.1590/S010181752007000200007

DAJOZ, R. Princípios de Ecologia. 7. ed. Porto Alegre: Artmed, 2005.

DOHET, A.; DOLISY, D.; HOFFMANN, L.; DUFRÊNE, M. Identification of bioindicator species among Ephemeroptera, Plecoptera and Trichoptera in a survey of streams belonging to the rhithral classification in the Grand Duchy of Luxembourg. Verhandlungen des Internationalen Verein Limnologie, v. 28, p. 381-386, 2002. http://hdl.handle.net/2268/202432

HEPP, L. U.; MILESI, S. V.; BIASI, C.; RESTELLO, R. M. Effects agricultural and urban impacts on macroinvertebrates assemblages in streams (Rio Grande do Sul, Brazil).

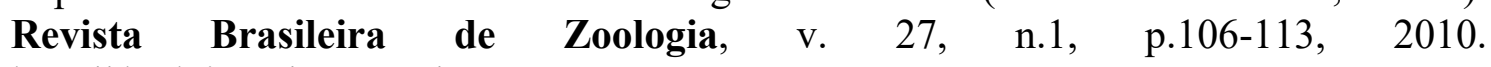
http://dx.doi.org/10.1590/S1984-46702010000100016 
HEPP, L.U.; RESTELLO, R.M. Macroinvertebrados bentônicos como bioindicadores da qualidade das águas do Alto Uruguai Gaúcho. In. ZAKRZEVSI, S.B.B. (Org.). Conservação e uso sustentável da água: múltiplos olhares. Erechim: Edifapes, 2007. p.7585.

HEPP, L. U.; SANTOS, S. Benthic communities of streams related to different land uses in a hydrographic basin in southern Brazil. Environmental Monitoring and Assessment, v. 157, p. 305-318, 2009.

GIULIATTI, T. L.; CARVALHO, E. M. Distribuição das assembleias de macroinvertebrados bentônicos em dois trechos do córrego Laranja Doce, Dourados/MS. Interbio, v. 3, n. 1, p. 4-14, 2009.

KÖNIG, R.; SUZIN, C. R. H.; RESTELLO, R. M.; HEPP, L. U. Qualidade das águas de rios da região norte do Rio Grande do Sul (Brasil) através de variáveis, físicas, químicas e biológicas. Pan-American Journal of Aquatic Sciences, v. 3, n. 1, p. 84-93, 2008

MARQUES, M. M.; BARBOSA, F. Biological quality of waters from an impacted tropical watershed (middle Rio Doce basin, southeast Brazil), using benthic macroinvertebrate communities as an indicator. Hydrobiologia, v. 457, p. 69-76, 2001.

MERRITT, R. W.; CUMMINS, K. W. An introduction to the aquatic insects of North America. 3. ed. Dubuque: Kendall/Hunt, 1996.

MUGNAI, R.; NESSIMIAN, J. L.; BAPTISTA, D. F. Manual de Identificação de Macroinvertebrados Aquáticos do Estado do Rio de Janeiro. Rio de Janeiro: Tecnical books Editora, 2010.

ROSENBERG, D. M.; RESH, V. H. Freshwater Biomonitoring and Benthic Macroinvertebrates. Journal of the North American Benthological Society, v. 12, n. 2 , p. 220-222, 1993.

SILVEIRA, M. P.; BUSS, D. F.; NESSIMIAN, J. L.; BAPTISTA, D. F. Spatial and temporal distribution of benthic macroinvertebrates in a Southeastern Brazilian river. Brazilian Journal Biology, v. 66, p. 623-632， 2006. http://dx.doi.org/10.1590/S151969842006000400006

SURIANO, M. T.; FONSECA-GESSMER, A. A. Chironomidae (Diptera) Larvae in streams of Parque Estadual de Campos do Jordão, São Paulo state, Brazil. Acta Limnológica Brasileira, v. 16, n. 2, p. 129-136, 2004.

TUNDISI, J. G.; MATSUMURA-TUNDISI, T. Biodiversidade no neotrópico: valores ecológicos, econômicos e sociais. Brazilian Journal of Biology, v. 68, n. 4, supl. 0, p. 913-915, 2008. http://dx.doi.org/10.1590/S1519-69842008000500002

VANNOTE, R. L.; MINSHALL, G. W.; CUMMINS, K. W.; SEDELL, J. R.; CUSHING, C. E. The river continuum concept. Canadian Journal of Fisheries and Aquatic Sciences, v. 37, p. 130-137, 1980. 


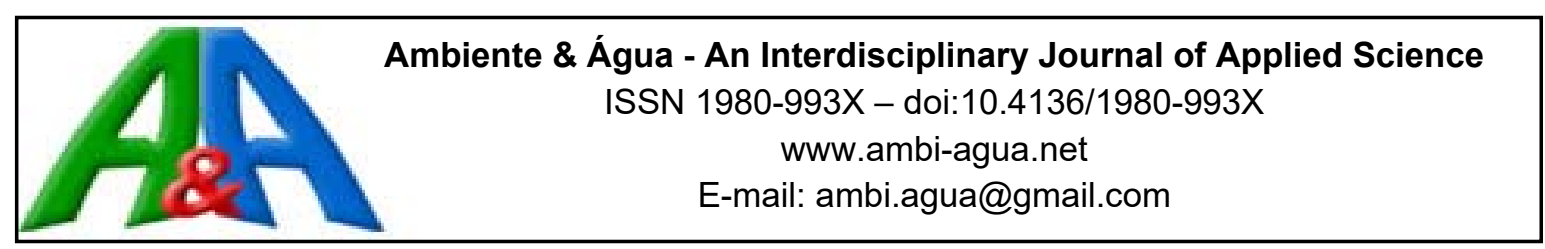

\title{
Validação de método analítico e de extração do malation em água e solo após nebulização de combate ao Aedes aegypti
}

doi:10.4136/ambi-agua.1993

Received: 27 Aug. 2016; Accepted: 22 Mar. 2017

\author{
Ana Carla Coleone ${ }^{1,2^{*}}$; Flavio Soares da Silva ${ }^{3}$; Angela Aparecida Machado ${ }^{2}$; \\ Joaquim Gonçalves Machado Neto ${ }^{2}$; Wanderley da Silva Paganini ${ }^{1}$ \\ ${ }^{1}$ Universidade de São Paulo (USP), São Paulo, SP, Brasil \\ Departamento de Saúde Ambiental \\ ${ }^{2}$ Universidade Estadual Paulista (UNESP), Jaboticabal, SP, Brasil \\ Departamento de Fitossanidade \\ ${ }^{3}$ Universidade Federal de Itajubá (UNIFEI) Itajubá, MG, Brasil \\ *Autor correspondente: e-mail: anacarlacb@yahoo.com.br, \\ flavio_ss_ss@yahoo.com.br, angela_machado88@hotmail.com, \\ joaquim@fcav.unesp.br, paganini@usp.br
}

\section{RESUMO}

O mosquito Aedes aegypti é vetor de doenças de grande relevância para a saúde pública, como a dengue, febre amarela, zika e chikungunya. Em áreas urbanas, para o controle dos insetos adultos, é realizada a nebulização a ultrabaixo volume (UBV) do malation. A pulverização pode levar à contaminação ambiental do solo e da água com o inseticida. Objetivou-se ajustar e validar um método analítico para determinação de malation em cromatografia líquida de alta eficiência (CLAE) e determinar o método de extração do inseticida das matrizes água e solo. A fase móvel foi uma mistura isocrática de acetonitrila e água (68:32), à vazão de $1 \mathrm{~mL}$ min $^{-1}$, o volume de injeção de $20 \mu 1 \mathrm{e}$ UV a $210 \mathrm{~nm}$. Após fortificação, o analito foi extraído com acetonitrila (ACN) por agitação mecânica nas amostras de solo, e por evaporação das amostras de água, pré-concentrado, redissolvido em ACN e a recuperação foi calculada. O método é simples, específico e adequado para análise do malation com linearidade entre as concentrações de 0,05 e $1,00 \mu \mathrm{g} \mathrm{mL} \mathrm{m}^{-1}\left(\mathrm{R}^{2}=0,999\right)$ e limites de

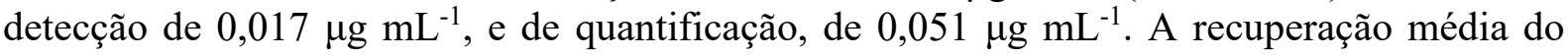
malation da água foi de $97 \%$ e do solo, $96 \%$, sendo o método exato e preciso (coeficiente de variação $<8,8 \%$ ). O método ajustado pode ser utilizado com segurança para quantificação do inseticida em matrizes de água e solo.

Palavras-chave: cromatografia líquida, inseticida, saúde pública.

\section{Analytical method of validation and extraction of malathion in water and soil after fogging against Aedes aegypti}

\begin{abstract}
The Aedes aegypti mosquito is a vector of diseases such as dengue, yellow fever, chikungunya and zika, which has great relevance to public health. In urban areas, ultra-low volume (ULV) malathion fogging is used for the control of adult mosquitoes. Spraying with the insecticide can contaminate soil and water. The goal of this study was to adjust and validate an
\end{abstract}


analytical method for the determination of malathion in high-performance liquid chromatography (HPLC) and determine the pesticide extraction method of water and soil matrices. The mobile phase used an isocratic mixture of acetonitrile and water (68:32), at a flow rate of $1 \mathrm{~mL} \mathrm{~min}^{-1}$, an injection volume of $20 \mu \mathrm{L}$, and a UV at $210 \mathrm{~nm}$. After fortification, the analyte was extracted with acetonitrile $(\mathrm{ACN})$ by mechanical agitation of the soil samples, and by evaporation of the water samples, pre-concentrated, re-dissolved in ACN, and the recovery was calculated. The method is simple, specific and suitable for analysis of malathion with linearity between concentrations of 0.050 and $1.00 \mu \mathrm{g} \mathrm{mL}^{-1}\left(\mathrm{R}^{2}=0.999\right)$ and detection limits of $0,017 \mu \mathrm{g} \mathrm{mL}^{-1}$ and quantification of $0.051 \mu \mathrm{g} \mathrm{mL} \mathrm{L}^{-1}$. The average recovery of malathion from water was $97 \%$, and from soil, $96 \%$, being the method exact and precise (coefficient of variation $<8.8 \%$ ). The set method can be safely used for the quantification of the insecticide in water and soil matrices.

Keywords: insecticide, liquid chromatography, public health.

\section{INTRODUÇÃO}

O mosquito Aedes aegypti é um dos maiores problemas da Saúde Pública nas regiões tropicais e subtropicais do mundo. Além de ser o principal vetor da dengue e da febre amarela em áreas urbanas no Brasil, recentemente foi identificado também como transmissor da zika e da chikungunya, arboviroses responsáveis por sérias disfunções ou malformações.

Em áreas de grande transmissão de doenças ocasionadas por esse vetor, é realizado o controle químico do inseto com a nebulização do inseticida organofosforado malation, aplicado com turbo atomizado, calibrado com volume de aplicação ultrabaixo volume (UBV) a frio, conforme orientação da Organização Mundial da Saúde (OMS) e do Ministério da Saúde (MS).

No Brasil, esta prática é realizada desde a década de 1960, com a aplicação do malation diluído em óleo de soja, e mais recentemente, em água. Para a nebulização são utilizados equipamentos de transporte costal ou acoplados a veículos, com aplicação nas vias públicas, terrenos, parques e praças, ou no interior das edificações (Brasil, 2009).

O controle vetorial a UBV consiste na fragmentação de uma pequena quantidade do inseticida pelo equipamento de aplicação, formando aerossóis. Parte destes aerossóis sofre deriva, podendo depositar-se sobre o solo e nas águas locais (Chaim, 1989). Portanto, ajustar métodos químicos analíticos e determinar resíduos do malation nas matrizes água e solo é de extrema importância para monitorar a contaminação ambiental devido ao combate ao A. aegypti com este inseticida, cujos efeitos tóxicos ao homem e demais organismos são comprovados por muitos pesquisadores.

A determinação de resíduos de pesticidas em diferentes matrizes é tradicionalmente realizada por meio de técnicas cromatográficas, devido à facilidade de separação, identificação e quantificação dos analitos presentes na amostra, e há diversos detectores com possibilidade de uso.

A cromatografia a gás $(\mathrm{CG})$ é uma técnica muito utilizada na quantificação de compostos organofosforados. Contudo, alguns autores descrevem métodos de análise por cromatografia líquida de alta eficiência (CLAE). Em análise de malation em plasma e urina, Abu-Qare e AbouDonia (2001) utilizaram um detector de ultravioleta (UV) a $210 \mathrm{~nm}$ e a fase móvel composta por acetonitrila e água. Em matriz água, Morales et al. (2012) utilizaram CLAE com detector de arranjo de diodos, e metanol e água como fase móvel. Kulluru et al. (2010) também utilizaram CLAE para análise de malation em solo, com fase móvel consistindo de acetonitrila e água e detector de UV a $254 \mathrm{~nm}$.

Para quantificação de um pesticida em determinada matriz é necessária a validação do método analítico, que consiste na determinação de alguns parâmetros como especificidade, 
linearidade, limites de detecção e quantificação, exatidão e precisão dos dados, como recomendado pela Resolução $n^{\circ} 899$ da Agência Nacional de Vigilância Sanitária - ANVISA (Anvisa, 2003) e pela NBR14029:2005 da ABNT (ABNT, 2005).

Ensaios de recuperação são normalmente utilizados para validação do método analítico a fim de estimar-se a exatidão e a precisão dos dados. Estes ensaios são realizados com a fortificação da matriz, ou seja, com adição de uma concentração conhecida do analito à amostra. Segundo Brito et al. (2003), a recuperação consiste na relação percentual entre a concentração real e a concentração determinada após aplicação do procedimento analítico, e é calculada para diferentes níveis de fortificação. A porcentagem adequada de recuperação de um analito é estabelecida em função de sua concentração, conforme as classes descritas pela Association of Official Analytical Chemists (AOAC, 1998).

A existência de interferentes nas matrizes e a presença das substâncias de interesse em baixas concentrações requerem a utilização de técnicas de extração, purificação no caso de amostras muito complexas, e pré-concentração para que a determinação dos componentes de interesse se torne possível. O objetivo final é a obtenção de uma subfração da amostra original limpa e enriquecida com as substâncias de interesse analítico. Uma maneira pouco custosa de pré-concentrar uma amostra é a evaporação seguida da redissolução do analito em um pequeno volume de solvente.

A extração de amostras livres de interferentes que prejudiquem a análise cromatográfica, como determinadas amostras de água, pode ser feita simplesmente com a evaporação e redissolução do composto de interesse em solvente específico (Amarante et al., 2002). Para a extração de pesticidas de matrizes mais complexas como o solo, os métodos mais frequentemente empregados são o Soxhlet, agitação mecânica e banhos ultrassônicos com solventes orgânicos como acetonitrila, hexano, diclorometano, acetona e acetato de etila (Bernal et al., 1996; Tahir et al., 2010).

O objetivo deste estudo foi ajustar e validar o método analítico para análise de malation em CLAE e determinar o método de extração do inseticida das matrizes água e solo.

\section{MATERIAL E MÉTODOS}

\subsection{Local de estudo}

Os estudos foram realizados no Laboratório de Ecotoxicologia dos Agrotóxicos e Saúde Ocupacional do Departamento de Fitossanidade da Faculdade de Ciências Agrárias e Veterinárias da Universidade Estadual Paulista (UNESP), campus de Jaboticabal.

\subsection{Reagentes e soluções}

Para validação do método cromatográfico em água e solo, foi utilizado o padrão analítico de malation (grau PESTANAL ${ }^{\circledR}$ ), com $97,5 \%$ de pureza. A acetonitrila utilizada foi de grau CLAE, da JT BAKER ${ }^{\circledR}$. A água ultrapura empregada na fase móvel foi obtida em equipamento Elga, PurelabUHQ.

As soluções estoques de malation para elaboração da curva analítica foram preparadas diluindo o padrão analítico em acetonitrila, em uma concentração de $1000 \mu \mathrm{g} \mathrm{mL}^{-1}$. Diluições sucessivas foram realizadas obtendo-se as concentrações de 0,$05 ; 0,10 ; 0,25 ; 0,50 ; 0,75$ e 1,00 $\mu \mathrm{g} \mathrm{mL} \mathrm{m}^{-1}$ de malation.

\subsection{Equipamentos}

A pesagem do padrão analítico foi realizada em balança analítica Sartorius, BL210S e do solo, em balança semianalítica Bel, P236. 
Para elaboração das soluções estoque e procedimentos de fortificação e extração do malation nas diferentes matrizes, foram utilizadas micropetas automáticas da marca Gilson e vidraria volumétrica adequada.

Um sistema de evaporador rotativo Fisaton, 802A, acoplado a um banho ultrassônico e um agitador de tubos Phoenix, YAP56, foram utilizados na extração do inseticida do solo e da água. Uma agitadora Tecnal, TE 421 foi empregada na extração do malation do solo.

A análise do inseticida foi realizada em sistema de cromatografia líquida de alta eficiência (CLAE) Surveyor LC ThermoFinnigan ${ }^{\circledR}$ acoplado a um detector UV visível (software Chromquest 4.1).

Toda a vidraria utilizada neste estudo foi higienizada de acordo com o preconizado pela NBR 13073 (ABNT, 2003).

\subsection{Validação do método analítico do malation por CLAE}

\subsubsection{Condições cromatográficas}

O método analítico foi adaptado do método descrito por Abu-Qare e Abou-Donia (2001). O sistema cromatográfico adotado foi composto por duas fases móveis 68:32 (v:v): acetonitrila grau CLAE (fase A) e água ultrapura (fase B), filtradas em membrana de $0,45 \mu \mathrm{m}$ e desgaseificadas em ultrassom por 15 minutos.

A vazão e o volume de injeção utilizados foram, respectivamente, $1 \mathrm{~mL} \mathrm{~min}^{-1} \mathrm{e} 20 \mu \mathrm{L}$ e o comprimento de onda utilizado no detector de ultravioleta (UV-visível) foi de $210 \mathrm{~nm}$. A coluna empregada foi ACE C18 $(250 \times 4,6 \mathrm{~mm})$ e $5 \mu \mathrm{m}$ de tamanho de partícula.

\subsubsection{Validação do método}

A validação do método analítico foi realizada após injeção de sete réplicas (NBR14029:2005; ABNT, 2005) de cada concentração de estudo para os parâmetros especificidade, linearidade, limites de detecção e quantificação e cinco réplicas (Resolução $n^{\circ}$ 899 da ANVISA; Brasil, 2003) para exatidão e precisão.

A curva analítica foi elaborada com concentrações variando de $0,05-1,00 \mu \mathrm{g} \mathrm{mL}^{-1}$, caracterizando o intervalo de trabalho, ou seja, a faixa da menor à maior concentração que pode ser determinada com precisão e exatidão em relação à linearidade e acima do limite de quantificação obtido pelo método.

Considerou-se a região linear, aquela em que o resultado obtido foi proporcional à concentração do analito. Para avaliação da linearidade, foi dividido o fator de resposta (área média/concentração) pela concentração. As áreas médias/concentração foram ordenadas e a mediana (independente dos valores anômalos) foi determinada com 10\% de variação superior e inferior.

A especificidade foi analisada para verificação da existência de interferência de compostos das matrizes na análise do inseticida.

O limite de detecção (LD), considerado como a menor concentração que pode ser detectada, mas não quantificada, e o limite de quantificação (LQ), considerado como a menor concentração que pode ser quantificada com exatidão e precisão aceitáveis, foram calculados a partir dos parâmetros da curva analítica das Equações 1 e 2.

$$
\begin{aligned}
& \mathrm{LD}=3,3 \times \frac{s d}{b} \\
& \mathrm{LQ}=3 \times L D
\end{aligned}
$$

em que:

$\mathrm{Sd}=$ desvio padrão da curva analítica, e 
$b=$ coeficiente angular da curva analítica.

A exatidão e a precisão intraensaio foram calculadas com três concentrações: no início $\left(0,05 \mu \mathrm{g} \mathrm{mL}^{-1}\right)$, meio $\left(0,50 \mu \mathrm{g} \mathrm{mL}^{-1}\right)$ e fim da curva analítica $\left(1,00 \mu \mathrm{g} \mathrm{mL}{ }^{-1}\right)$. Para o cálculo da exatidão, utilizou-se o valor da recuperação das amostras. Já a precisão foi calculada pela dispersão dos resultados e expressa pelo coeficiente de variação dos dados obtidos.

\subsection{Método de extração do malation das matrizes de água e solo}

\subsubsection{Fortificação e extração das amostras}

Testes de fortificação e recuperação do malation em $10,00 \mathrm{~mL}$ de água e $10,00 \mathrm{~g}$ de solo argiloso foram realizados em sala climatizada a $20 \pm 5^{\circ} \mathrm{C}$, a fim de verificar-se a porcentagem de recuperação do analito após o processo de pré-concentração e extração das matrizes. $\mathrm{O}$ volume de água e a massa de solo escolhidos neste estudo ocorreu para que a pré-concentração satisfizesse a quantificação do inseticida nas amostras de campo acima do limite de quantificação após a pulverização do inseticida na dose de campo indicada pelo Ministério da Saúde de $146 \mathrm{~g} \mathrm{ha}^{-1}$ (Brasil, 2009).

A água utilizada nestes testes foi proveniente de sistema público de abastecimento, sem passar por processo de destilação, filtrada em filtro de $0,45 \mu \mathrm{m}$ e livre da contaminação por malation, como indicaram as análises cromatográficas prévias desta matriz. O mesmo foi observado para o solo, predominantemente argiloso (57\% de argila), obtido da camada de 0-20 $\mathrm{cm}$ de profundidade do campo da Fazenda Experimental da Faculdade de Ciências Agrárias e Veterinárias de Jaboticabal.

As amostras foram fortificadas adicionando-se $1 \mathrm{~mL}$ de padrão analítico de 0,$05 ; 0,5 \mathrm{e}$ $1,0 \mu \mathrm{g} \mathrm{mL} \mathrm{m}^{-1} \mathrm{em} 9 \mathrm{~mL}$ de água, correspondentes a três níveis da curva padrão: o mais baixo, um médio e o maior, obtendo-se dessa maneira, concentrações de $0,005 \mu \mathrm{g} \mathrm{mL}{ }^{-1} ; 0,05 \mu \mathrm{g} \mathrm{m} \mathrm{L}^{-1} \mathrm{e}$ $0,1 \mu \mathrm{g} \mathrm{mL} \mathrm{L}^{-1}$.

As amostras de solo foram umidificadas com $1 \mathrm{~mL}$ de acetonitrila e então fortificadas. Após este processo foram vigorosamente homogeneizadas manualmente e em agitadora por 10 minutos, sendo então deixadas em repouso por 2 horas no escuro, com ventilação constante a $20^{\circ} \mathrm{C}$ para eliminação do solvente. A metodologia utilizada neste processo foi baseada principalmente no trabalho de Bernal et al. (1996) para extração de herbicidas.

Em seguida, volumes de $30 \mathrm{~mL}$ de acetonitrila foram adicionados às amostras, que foram agitadas por 2 horas. O solvente, por sua vez, foi coletado e filtrado em filtro de $0,45 \mu \mathrm{m}$, dentro de balão de fundo redondo. Mais $20 \mathrm{~mL}$ de acetonitrila foram adicionados às amostras de solo, que seguiram para agitação por mais 30 minutos, material posteriormente coletado e devidamente filtrado.

Os balões contendo as amostras seguiram para rotoevaporação a $40 \mathrm{rpm}$ nas mesmas condições das amostras de água, em evaporador rotativo, cujo banho de aquecimento foi de $60^{\circ} \mathrm{C}$ e o banho ultratermostatizado, a $4^{\circ} \mathrm{C}$, até a evaporação total da solução, quando foi removido do sistema e deixado em repouso até resfriamento à temperatura ambiente.

Então, $1 \mathrm{~mL}$ de acetonitrila foi adicionado ao balão, que seguiu para um banho ultrassônico por 10 minutos. Após esta etapa, o balão foi agitado por mais 2 minutos em agitador de tubos. Em seguida, a amostra foi coletada e transferida para vial, seguindo para análise em CLAE.

\subsubsection{Recuperação das amostras}

A recuperação do analito das amostras de água e solo foi calculada segundo a seguinte fórmula da Equação 3. 


$$
\% \operatorname{Rec}=\frac{\text { Concobs }}{\text { Concexp }} \times 100
$$

em que:

$\% \operatorname{Rec}=$ recuperação percentual do analito obtido no ensaio de recuperação,

Concobs $=$ concentração observada do analito na solução contaminada, e

Concexp $=$ concentração esperada do analito na solução contaminada.

A recuperação para as três concentrações de estudo foi verificada de acordo com a faixa recomendada pela Association of Official Analytical Chemists (AOAC, 1998). Segundo a AOAC, o nível aceitável para recuperação de agrotóxicos em diferentes matrizes depende da concentração investigada. Os valores aceitos encontram-se na Tabela 1.

Tabela 1. Nível aceito de recuperação de um analito em função da sua concentração.

\begin{tabular}{lc}
\hline $\begin{array}{c}\text { Concentração do analito } \\
(\%)\end{array}$ & $\begin{array}{c}\text { Intervalo de } \\
\text { recuperação aceito } \\
(\%)\end{array}$ \\
\hline$\geq 10$ & $98-102$ \\
$\geq 1$ & $97-103$ \\
$\geq 0,1$ & $95-105$ \\
$\geq 0,01$ & $90-107$ \\
$\geq 0,001->0,0001$ & $80-110$ \\
$\geq 0,000001$ & $60-115$ \\
$\geq 0,0000001$ & $40-120$ \\
\hline
\end{tabular}

Fonte: Brito et al. (2003).

\section{RESULTADOS E DISCUSSÃO}

\subsection{Validação do método analítico do malation por CLAE}

A curva analítica obtida após a injeção dos padrões de 0,$05 ; 0,10 ; 0,25 ; 0,50 ; 0,75$ e $1,00 \mu \mathrm{g} \mathrm{mL}^{-1}$ de malation encontra-se na figura 1 . O coeficiente de linearidade obtido $\left(\mathrm{R}^{2}\right)$ foi de 0,999 , indicando uma correlação fortíssima entre as variáveis.

O tempo de retenção do analito foi de 4,2 minutos e o tempo de corrida cromatográfica, de 10 minutos para água e 20 minutos para solo.

O método analítico foi específico para malation em solo e água. O limite de detecção calculado foi de $0,017 \mu \mathrm{g} \mathrm{mL}^{-1}$ e o limite de quantificação, $0,051 \mu \mathrm{g} \mathrm{mL}^{-1}$.

Muitos métodos analíticos são descritos para análise de malation por cromatografia gasosa e para análise de múltiplos resíduos (Bernal et al., 1996; Abu-Qare e Abou-Donia, 2001) e requerem um pré-tratamento das amostras, o que ocasiona um encarecimento do processo de extração.

O método proposto neste estudo é simples, utiliza modo isocrático no sistema de CLAE e dispensa o tratamento complexo das amostras, sem provocar prejuízos às análises cromatográficas, oferecendo uma vantagem metodológica e financeira em relação aos métodos normalmente descritos. 


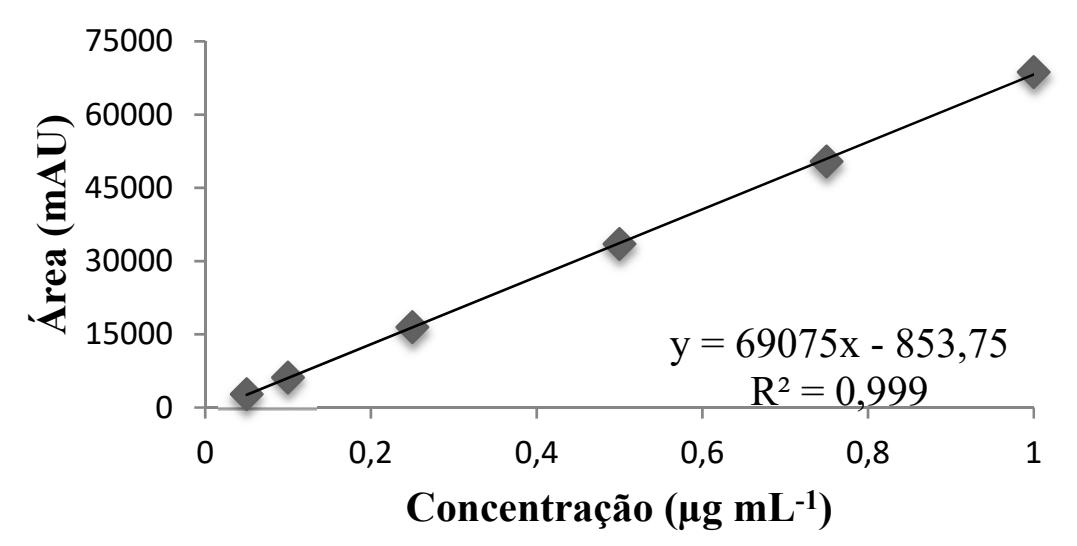

Figura 1. Curva analítica obtida para o inseticida malation com as concentrações de $0,05-1,00 \mu \mathrm{g} \mathrm{mL}^{-1}$.

A redução do tempo da corrida das amostras também é vantajosa quando comparada a métodos multirresíduos. Tahir et al. (2010) obtiveram um tempo de corrida de 28,5 minutos para separação de malation e clorpirifós de amostras de solo por cromatografia gasosa acoplada a detector de nitrogênio e fósforo, com tempo de retenção $\left(t_{R}\right)$ de 18,9 minutos para o inseticida. Morales et al. (2012) analisaram diferentes agrotóxicos em amostras de águas superficiais de regiões agrícolas por CLAE com detector de arranjo de diodos. A duração da corrida cromatográfica do método desenvolvido pelos autores foi de 115 minutos.

Este tempo foi bastante reduzido de acordo com a metodologia aqui proposta, com 10 minutos de corrida cromatográfica para amostras de água e 20 minutos para solo, com tr de 4,2 minutos para o inseticida em ambas as matrizes.

Abu-Qare e Abou-Donia (2001) obtiveram um limite de detecção e quantificação de 0,050 e $0,10 \mu \mathrm{g} \mathrm{mL}^{-1}$ para o malation em metodologia multirresíduos desenvolvida para análise de amostras de plasma e urina humana em CLAE, calculados na proporção de 1:3 e 1:10 do ruído da linha de base. Estes valores são maiores quando comparados com aqueles encontrados neste trabalho $\left(\mathrm{LD}=0,017 \mu \mathrm{g} \mathrm{mL} \mathrm{L}^{-1} \mathrm{e} \mathrm{LQ}=0,051 \mu \mathrm{g} \mathrm{mL}^{-1}\right)$.

\subsection{Método de Extração do Malation das Matrizes de Água e Solo}

As porcentagens de recuperação do malation em solo e água após extração e préconcentração encontram-se na Tabela 2. Todos os valores foram enquadrados na faixa recomendada pela AOAC (1998) para os níveis de fortificação investigados.

Tabela 2. Porcentagem de recuperação do malation em água e solo para três níveis de concentração.

\begin{tabular}{|c|c|c|c|c|c|c|}
\hline \multirow[b]{2}{*}{$\begin{array}{c}\text { Concentração } \\
\left({ }^{\mathrm{a}} \mathrm{mg} \mathrm{L}^{-1} /{ }^{\mathrm{b}} \mathrm{mg} \mathrm{kg}^{-1}\right)\end{array}$} & \multicolumn{3}{|c|}{ Água ${ }^{a}$} & \multicolumn{3}{|c|}{ Solo $^{b}$} \\
\hline & $\begin{array}{c}\% \\
\text { Recuperação }\end{array}$ & $\mathrm{DP}^{1}$ & $\mathrm{CV}^{2}$ & $\begin{array}{c}\% \\
\text { Recuperação }\end{array}$ & $\mathrm{DP}^{1}$ & $\mathrm{CV}^{2}$ \\
\hline 0,005 & 99 & 1,29 & 1,31 & 100 & 8,85 & 8,83 \\
\hline 0,050 & 97 & 0,82 & 0,85 & 94 & 5,88 & 6,27 \\
\hline 0,100 & 95 & 0,24 & 0,27 & 95 & 5,49 & 5,85 \\
\hline Média & 97 & & & 96 & & \\
\hline
\end{tabular}

Nota: ${ }^{1}=$ desvio padrão, $\mathrm{e}^{2}=$ coeficiente de variação $(\%),{ }^{\mathrm{a}}=\mathrm{mg} \mathrm{L}^{-1}$ para água, $\mathrm{e}^{\mathrm{b}}=\mathrm{mg} \mathrm{kg}^{-1}$ para solo. 
A exatidão expressa pelo fator de recuperação, e a precisão expressa pelo coeficiente de variação (CV) estão de acordo com o recomendado pela ANVISA (2003) e ABNT (2005), bem como os outros parâmetros já discutidos anteriormente, garantindo a confiabilidade dos resultados de análise.

A recuperação obtida para malation por Tahir et al. (2010) em seis réplicas de solo proveniente de um campo de golfe fortificado com $10 \mu \mathrm{g} \mathrm{g}^{-1}$ do inseticida foi de 88,5 a 99,9\%, utilizando o método de soxhlet e pré-concentração em rotoevaporador. De acordo com Karyab et al. (2013), a recuperação de malation em amostras de água variou de 45 a 63\%, com microextração em banho ultrassônico utilizando tolueno. Estes valores de recuperação são inferiores aos obtidos neste estudo para ambas as matrizes, indicando a eficiência da metodologia descrita para a extração do inseticida.

De acordo com a especificidade, a linearidade, o limite de detecção e quantificação, a precisão e a exatidão calculados e através das porcentagens de recuperação obtidas nos três níveis de estudo, o método é considerado adequado para análise de malation em amostras de água e solo argiloso.

\section{CONCLUSÃO}

A validação do método cromatográfico desenvolvido neste estudo atende às exigências da Resolução 899/2003 (2003) e da NBR14029 (ABNT, 2005), e garante a confiabilidade dos resultados. A recuperação média do malation obtida após os processos de extração e pré-concentração desenvolvidos para as matrizes água e solo é de 97 e 96\%, respectivamente, e estão enquadradas na faixa recomendada pela AOAC (1998) para os níveis de concentração de estudo.

Este método apresenta vantagens em relação a outros descritos para determinação do malation em amostras de água e solo, principalmente em relação ao procedimento de extração, tempo de análise e limites de detecção e quantificação, além de ser facilmente executado e de gerar dados satisfatoriamente interpretáveis. A aplicação da metodologia aqui proposta às amostras ambientais de água e solo possibilitará uma compreensão do estudo deste contaminante nestas matrizes, mostrando-se uma importante ferramenta na gestão da saúde ambiental.

\section{REFERÊNCIAS}

ASSOCIAÇÃO BRASILEIRA DE NORMAS TÉCNICAS - ABNT. Nbr 13073: limpeza de vidrarias para uso de ensaios de produtos agrotóxicos e afins. Rio de Janeiro, 2003.

ASSOCIAÇÃO BRASILEIRA DE NORMAS TÉCNICAS - ABNT. Nbr 14029: agrotóxico e afins - validação de métodos analíticos. Rio de Janeiro, 2005.

ABU-QARE, A. W.; ABOU-DONIA, M. B. Simultaneous determination of malathion, permethrin, DEET (N,N-diethyl-m toluamide), and their metabolites in rat plasma and urine using high performance liquid chromatography. Journal of Pharmaceutical and Biomedical Analysis, v. 26, n. 2, p. 291-299, 2001. http://dx.doi.org/10.1016/S07317085(01)00407-1

AMARANTE Jr, O. P.; SANTOS, T. C. R.; BRITO, N. M.; RIBEIRO, M. L. Métodos de extração e determinação do Herbicida Glifosato: Breve Revisão. Química Nova, v. 25, n. 3, p. 420-428, 2002. http://dx.doi.org/10.1590/S0100-40422002000300015

AGÊNCIA NACIONAL DE VIGILÂNCIA SANITÁRIA (Brasil) - ANVISA. Resolução RE No 899, de 29 de março de 2003. Diário Oficial [da] União, 02 jun. 2003. 
ASSOCIATION OF OFFICIAL ANALYTICAL CHEMISTS - AOAC. Peer-Verified Methods Program, Manual on Policies and Procedures. Gaithersburg, 1998.

BERNAL, J. L.; NOZAL, M. J.; MARTIN, M. T.; JIMÉNEZ, J. J. Possibilities of gas chromatography-atomic emission detection in pesticide multiresidue analysis Application to herbicide analysis in soils. Journal of Chromatography A, v. 754, n. 1-2, p. 245-256, 1996. http://dx.doi.org/10.1016/S0021-9673(96)00200-2

BRASIL. Departamento de Vigilância Epidemiológica. Diretrizes nacionais para prevenção e controle de epidemias de dengue - Série A. Brasília, 2009. 160 p.

BRITO, N. M.; AMARANTE Jr., O. P.; POLESE, L.; RIBEIRO, M. L. validação de métodos analíticos: estratégia e discussão. Pesticidas: Revista de Ecotoxicologia e Meio Ambiente, v. 13, p. 129-146, 2003. http://dx.doi.org/10.5380/pes.v13i0.3173

CHAIM, A. Processos de aplicação de produtos fitossanitários e contaminação ambiental. Circular Técnica no 3. Jaguariúna: EMBRAPA; CNPDA, 1989.

KARYAB, H.; MAHVI, A. H.; NAZMARA, S.; BAHOJB, A. Determination of water sources contamination to diazinon and malathion and spatial pollution patterns in Qazvin, Iran. Bulletin of Environmental Contamination and Toxicology, v. 90, p. 126-131, 2013. http://dx.doi.org/10.1007/s00128-012-0880-8

KULLURU, P. P.; DAS, B. S.; PANDA, R. K. Evaluation of Sorption and Leaching Potential of Malathion and Atrazine in Agricultural Soils of India. International Journal of Environmental Research, v.4, n. 1, p. 75-90, 2010. http://hdl.handle.net/1807/4949

MORALES, Y. M.; GARCIA, M. F.; QUINTERO, A. B.; DIAZ, P. B.; CONTRERAS, L. M. Niveles de plaguicidas en aguas superficiales de una región agrícola del estado Mérida, Venezuela, entre 2008 y 2010. Revista Internacional de Contaminación Ambiental, v. 28, n. 4, p. 289-301, 2012.

TAHIR, N. M.; SOON, K. H.; ARIFFIN, M. M.; SURATMAN, S. Chlorpyrifos and malathion residues in soils of a terengganu golf course: a case study. The Malaysian Journal of Analytical Sciences, v. 14, n. 2, p. 82-87, 2010. 


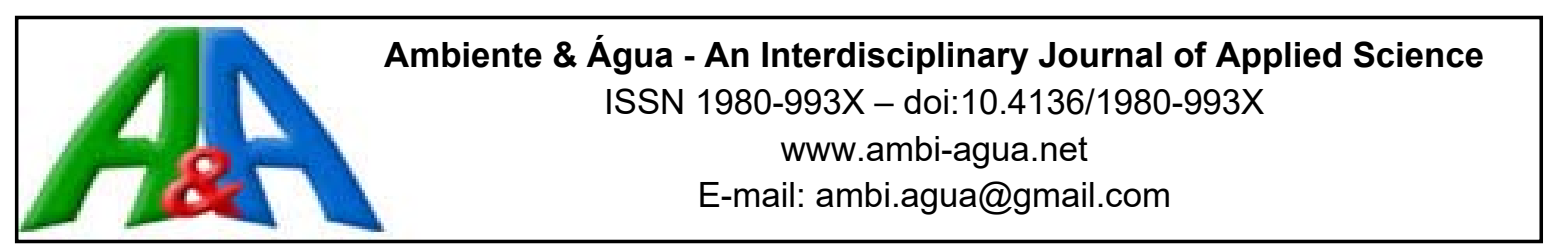

\title{
Caracterização de parâmetros de qualidade da água na área portuária de Barcarena, PA, Brasil
}

\author{
doi:10.4136/ambi-agua.1910
}

Received: 03 Apr. 2016; Accepted: 03 Mar. 2017

\begin{abstract}
Alba Rocio Aguilar Piratoba; Hebe Morganne Campos Ribeiro*; Gundisalvo Piratoba Morales; Wanderson Gonçalves e Gonçalves
\end{abstract}

\author{
Universidade do Estado do Pará (UEPA), Belém, PA, Brasil \\ *Autor correspondente: e-mail: hebemcr@gmail.com, \\ alba_roapt@hotmail.com,gundymorales@gmail.com, \\ wanderson_goncalves@rocketmail.com
}

\section{RESUMO}

Empresas no pólo industrial do município de Barcarena-PA utilizam matérias primas, insumos e energia e geram resíduos sólidos, efluentes industriais e esgoto doméstico que são lançados em corpos receptores, alterando as suas características físicas, químicas e microbiológicas. Visando determinar a influência das empresas localizadas no pólo industrial de Barcarena, foi realizado um estudo em um trecho do Rio Pará que sofre influência do lançamento de efluentes industriais das empresas em operação. Para tal, foram selecionados quatro pontos amostrais onde foram realizadas duas campanhas, sendo uma realizada no período menos chuvoso e outra no período chuvoso. Em cada campanha, foram coletadas amostras simultaneamente nos quatro pontos de amostragem durante um período de 12 horas, com intervalos de 90 minutos, iniciando e terminando a coleta no final da vazante. Foram coletadas 36 amostras nos 4 pontos selecionados em cada campanha de amostragem da maré, totalizando 72 amostras nas duas campanhas realizadas. Nas amostras, foram quantificadas variáveis hídricas como: $\mathrm{pH}$, temperatura, condutividade, sólidos totais dissolvidos (STD), cor, sódio, cálcio, potássio, cloreto, alcalinidade e dureza. Os dados foram analisados utilizando o teste estatístico ANOVA de dois fatores com a finalidade de observar se as diferentes variáveis analisadas apresentavam diferenças significativas entre os pontos de amostragem e a sazonalidade, usando nível de significância de 95\%. Foi também calculado o Índice de Qualidade de Água (IQA-CETESB). Os testes estatísticos mostraram que a localização dos pontos de amostragem não exerceu influência nos teores médios de $\mathrm{pH}$, porém houve influência significativa para as demais variáveis. Quanto à sazonalidade, houve diferença significativa em praticamente todas as variáveis, com exceção do cloreto e alcalinidade. As amostras de águas apresentaram IQA de qualidade ótima e boa.

Palavras-chave: água, ANOVA, efluentes.

\section{Characterization of water quality parameters in the port area of Barcarena, PA, Brazil}

\begin{abstract}
Companies in the industrial hub of Barcarena-PA city use raw materials, supplies and energy that generate solid waste, industrial effluents and domestic sewage that are released in
\end{abstract}


water bodies, changing their physical, chemical and microbiological characteristics. To determine the influence of the companies located in the industrial hub of Barcarena, a study was conducted in a stretch of Pará River under the influence of industrial effluents released by operating companies. Four sampling sites were therefore selected where two campaigns were conducted, one held in the less rainy period and another in the rainy season. Within each field, samples were collected simultaneously at four sample points over a period of 12 hours with 90 minute intervals starting and ending at the end of the ebb tide. We collected 36 samples in the 4 selected points in each sampling campaign of the tide, totaling 72 samples in the two campaigns. Samples were analyzed for $\mathrm{pH}$, temperature, conductivity, total dissolved solids (STD acronym in Portuguese), color, sodium, calcium, potassium, chloride, alkalinity and toughness. The ANOVA test of two factors was used in order to observe whether the variables showed significant differences between the sampling points and seasonality at a 95\% significance level. The Water Quality Index (IQA-CETESB) was also calculated. Statistical tests showed that the location of the sampling sites had no influence on the average levels of $\mathrm{pH}$, however there was a significant influence on the other variables. Regarding seasonality, there was no significant difference in all variables, except for chloride and alkalinity. The water samples showed IQA of excellent and good quality.

Keywords: ANOVA, effluent, water.

\section{INTRODUÇÃO}

A água é um dos recursos naturais mais importantes no planeta e até bem pouco tempo era considerado como um bem infinito. $\mathrm{O}$ aumento da população e todos os fatores atrelados com este crescimento têm ocorrido em detrimento da degradação dos recursos hídricos por causa de seus usos múltiplos, destacando entre eles a agricultura, o abastecimento público, a pecuária, a indústria, a geração de energia, o saneamento básico, a recreação e o lazer (Zhang et al., 2010; FAO, 2015). Embora a maior parte da superfície da Terra esteja ocupada de água, somente cerca de $2,5 \%$ são de água doce, com um mínimo de $0,06 \%$ correspondente à água dos rios, lagos, biomassa entre outros. O restante da água doce está no subsolo e nas calotas polares sendo estas duas de difícil acesso (Esteves, 2011).

Segundo Von Sperling (2007), a qualidade de uma água está determinada por fenômenos naturais e antrópicos exercidos na bacia hidrográfica. A água é o solvente universal, transportando gases, elementos e substâncias, e compostos orgânicos dissolvidos que são à base da vida no planeta (Tundisi e Matsumura-Tundisi, 2008). Na natureza, o ciclo hidrológico é o mecanismo que permite a mudança de estado físico e permite o contato com diferentes ambientes; dentro das etapas do ciclo é conferida uma natureza química à água. As características da água natural estão determinadas pelas substâncias químicas dissolvidas, diretamente relacionadas com a geoquímica do solo e das rochas nas bacias hidrográficas que drenam os rios e lagos (Von Sperling, 2007; Drever, 1988). Corpos de águas como os rios são sistemas que transportam substâncias, podendo apresentar diferentes concentrações de compostos nas nascentes, no meio e no baixo curso de um rio (Zhang et al., 2010).

De acordo com a legislação, a definição da qualidade da água faz referência ao tipo de uso ao qual se destina, e estipula os padrões de qualidade na resolução 357 do Conselho Nacional do Meio Ambiente (CONAMA) de 2005 e suas modificações nas resoluções 410 de 2009 e 430 de 2011. Os parâmetros são definidos em limites aceitáveis das substâncias presentes de acordo com o uso da água.

No caso específico de Barcarena-PA, desde os anos 80, às margens do Rio Pará expande-se um pólo industrial, onde na atualidade estão instaladas empresas com beneficiamento de

Rev. Ambient. Água vol. 12 n. 3 Taubaté - May / Jun. 2017 
alumínio e caulim e outros empreendimentos tais como Albras/Alunorte, Usina Siderúrgica do Pará-USIPAR e Rio Capim Caulim \& Pará Pigmentos S.A., Alubar, unidade de produção de fertilizantes da Bunge (CDP, 2010), sem deixar de lado a implantação do Porto de Vila do Conde.

Neste estudo, o objetivo foi fazer a determinação da qualidade da água em um trecho do rio Pará no município de Barcarena-PA e avaliar a influência das indústrias localizadas no pólo industrial.

Muitos estudos da qualidade da água são realizados mundialmente, como os realizados por Carreón et al. (2013) na lagoa Yuriria no México nos períodos de 2005 e 2009-2010 com a finalidade de avaliar variações espaciais e temporais das características da água. Em outro estudo realizado, Goher et al. (2014), no Canal de Ismaília no rio Nilo no Egito, avaliaram o índice de qualidade da água (IQA) e de alguns metais pesados. Chán Santisteban e Peña (2015) avaliaram alguns parâmetros de qualidade da água numa bacia da Guatemala que abastece a cidade para o consumo urbano. No Brasil também existem estudos como os de Bucci e Oliveira (2014) que avaliaram a qualidade da água e o estado trófico na Represa Dr. João Penido em Juiz de Fora- MG. Lobato et al. (2015) avaliaram a qualidade da água no lago Tucuruí- PA. Outro estudo de Oliveira e Cunha (2014), realizado no rio Jari - AP, avaliou a variabilidade da qualidade da água sob influência da precipitação mensal. Observa-se que estes estudos são importantes fontes de informações para conhecer as características e os efeitos de ações naturais e antrópicas exercidas nos corpos de água.

\section{METODOLOGIA}

A área de estudo localiza-se no município de Barcarena, pertencente à região metropolitana de Belém, PA, Brasil. Tal município limita-se ao Norte com a Baía de Guajará e Município de Belém, ao Sul com os Municípios de Moju e Abaetetuba, a Leste com a Baía de Guajará e Município de Acará e a Oeste com a Baía do Marajó (Município de Barcarena, 2011). Segundo a classificação de Köppen possui um clima tropical chuvoso de tipo Afi, com a presença de chuvas durante todo o ano (INMET, 2012). A média da precipitação pluvial anual é de $2500 \mathrm{~mm}$. Essas mudanças são, segundo Cohen et al. (2007), decorrentes em parte do desaparecimento da formação de nuvens baixas e médias formadas a partir de aerossóis de queimadas. A vegetação é tropical com Floresta Densa nas áreas elevadas; vegetação de Várzeas típicas de áreas inundáveis e Floresta Secundária (Ribeiro et al., 2013), ecossistemas que sofrem contínuas modificações pela presença do complexo industrial na localidade. $\mathrm{Na}$ porção continental, os solos predominantes são o Latossolo Amarelo distrófico, o Podzol Hidromórfico e Concrecionário Laterítico indiscriminado distrófico, textura indiscriminada (EMBRAPA, 2013). Entre as atividades produtivas destaca-se a agricultura, pesca artesanal e a indústria, principalmente pela locação de empresas com beneficiamento de alumínio implantado desde a década de 80 e em contínuo crescimento, decorrente de atividades minero-metalúrgicas e portuárias, sendo esta última devido à criação do Porto da Vila do Conde (Paz et al., 2011).

Foram selecionados quatro pontos de amostragem P-01, P-02, P-03 e P-04, denominados e georreferenciados como P-01 Rio Arienga (S 744945,8 O 9822509,3 UTM); P-02 na frente das empresas Pará Pigmentos S.A. (PPSA) e Imerys Rio Capim Caulim (IRCC) (S 747086,9 O 9826412,2 UTM); P-03 frente da Vila do Conde (S 748593,8 O 9828178,9 UTM) e P-04 na frente da praia do Caripi (S 754846,6 O 9835755,1 UTM). A Figura 1 mostra a localização dos pontos de amostragem do corpo hídrico estudado. A seleção dos pontos de amostragem foi realizada com a finalidade de comparar estatisticamente os diferentes parâmetros analisados no corpo hídrico. 


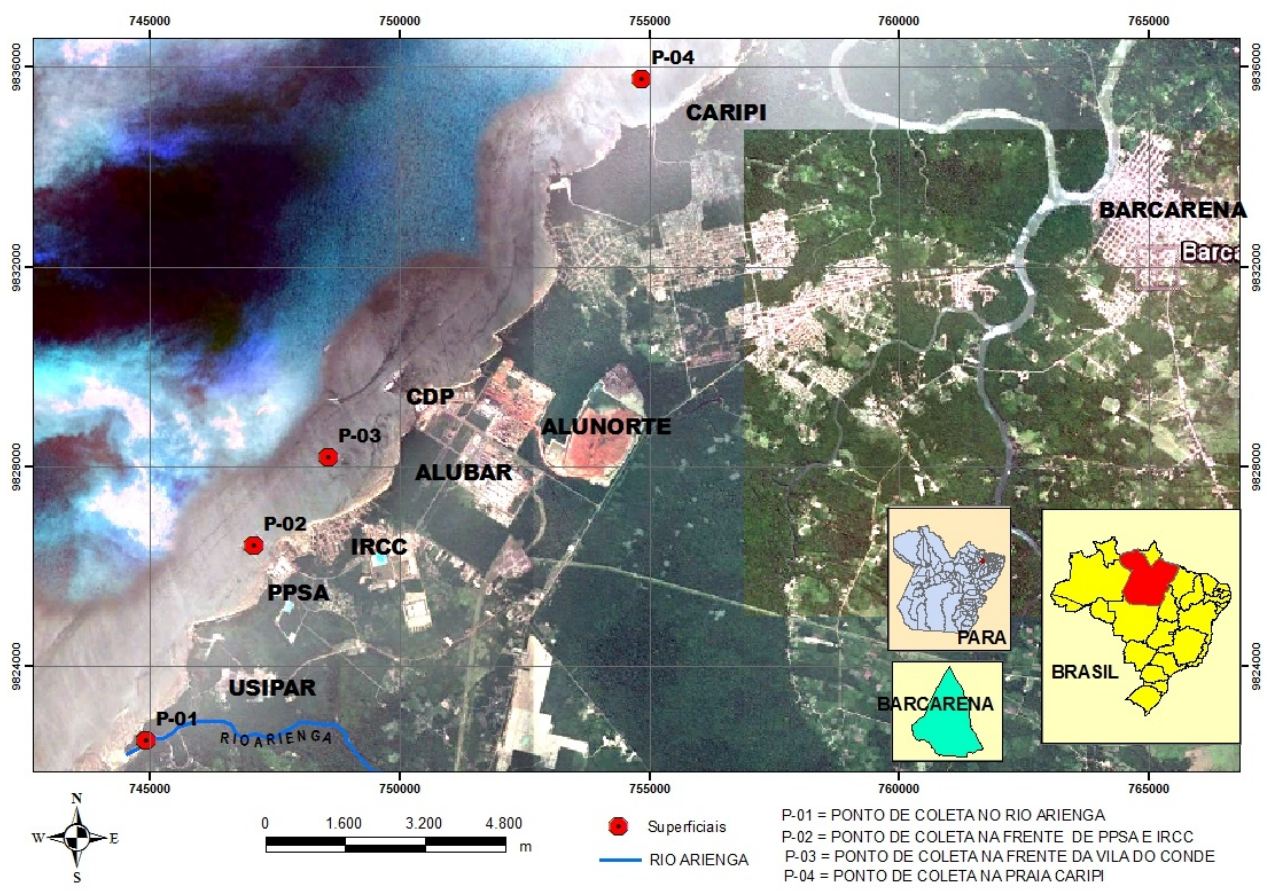

Figura 1. Mapa de localização da área de estudo e dos pontos de amostragem, onde (P-01) Rio Arienga, (P-02) frente de PPSA e IRCC, (P-03) frente da Vila do Conde e P-04 frente na praia Caripi.

A amostragem foi realizada considerando um período sazonal. A primeira foi realizada em dezembro de 2011 (período menos chuvoso) com uma temperatura máxima de $33,3^{\circ} \mathrm{C}$ e a mínima de $22,8^{\circ} \mathrm{C}$, ausência de precipitações e insolação de 9,4 . Por outro lado, a segunda amostragem foi realizada em junho de 2012 (período mais chuvoso) com as temperaturas máxima de $31,4^{\circ} \mathrm{C}$ e mínima de $21,4^{\circ} \mathrm{C}$, a precipitação de $1 \mathrm{~mm}$ e insolação com valor 0 (INMET, 2012).

Esta amostragem foi simultânea nos quatro pontos de coleta em um período de 12 horas contínua, com intervalos a cada 90 minutos, durante um ciclo de maré, iniciando às 6:00 horas e finalizando às 18:00 horas. A amostragem foi realizada de acordo como as normas da Associação Brasileira de Normas Técnicas e da Companhia Ambiental do Estado de São Paulo - CETESB. Cada coleta foi realizada manualmente em garrafas de polietileno de diferentes volumes devidamente lavadas e esterilizadas em autoclaves. Em campo, as garrafas foram acondicionadas com água do próprio corpo hídrico e colocadas em contra corrente ao fluxo da correnteza para coletar a amostra, e finalmente foram armazenadas em caixas de isopor em refrigeração (ABNT, 1987). A temperatura foi medida em campo usando termômetro digital da marca HANNA HI 98501. As medidas de $\mathrm{pH}$ e condutividade foram realizadas utilizando equipamentos da marca DIGIMED, pH-metro DM 2P e condutivímetro DM 3P. O condutivímetro também foi utilizado para a medida de sólidos totais dissolvidos. As amostras foram transportadas ao laboratório de Hidrocarbonetos (LABOHI) do Centro de Ciências Naturais e Tecnologia da Universidade do Estado do Pará. No laboratório, foram realizadas a determinação de cor com o colorímetro DM-COR. Para a análise de sódio $(\mathrm{Na})$, cálcio $(\mathrm{Ca})$ e potássio $(\mathrm{K})$, utilizou-se o fotômetro de chama DM- 62, com equipamentos devidamente calibrados. O cloreto foi determinado por titulação com nitrato de prata, conforme a norma NBR 13797. A alcalinidade foi obtida pelo método de titulação da norma técnica L5. 102, e a dureza pela titulação com EDTA, norma técnica da CETESB L5.124. Os coliformes termotolerantes foram determinados pelo método de Tubos Múltiplos de acordo com o método 
estabelecido pelo Standard Methods for the Examination of Water \& Wastewater method 9230 - B (APHA et al., 1995).

Para a sistematização dos resultados foi utilizada a estatística descritiva, tabulando a mediana e o desvio padrão (Tabela 1). O tratamento estatístico para a comparação dos dados foi realizado pelo teste de Análise da Variância (ANOVA) de dois fatores com repetição. $\mathrm{O}$ teste ANOVA é um teste de hipótese para comparar as médias de duas ou mais populações. $\mathrm{Na}$ ANOVA com fator duplo, os fatores A e B podem influenciar na variável dependente de forma isolada (efeitos principais) e de forma combinada, efeito de uma combinação específica dos fatores A e B (Lapponi, 2005). Para este estudo, os fatores foram definidos assim: o fator sazonalidade, que faz referência às duas campanhas de coleta realizadas; o fator localização, que são os quatro pontos de amostragem distribuídos espacialmente na área de estudo, e as interações dos dois fatores formam oito grupos com nove observações (número de amostras coletadas em cada ponto). Segundo o anterior, os testes de hipóteses são três hipóteses nulas: Ho1 - que não há efeito pela sazonalidade (duas campanhas de coleta), Ho2 - que não há efeito entre os quatro pontos de amostragem e $\mathrm{Ho} 3$ - que não há combinação entre os efeitos sazonalidade e pontos de amostragem. As hipóteses alternativas são $\mathrm{H}_{1}$, que há efeito em cada um dos três casos. Este teste de hipóteses é para cada um dos parâmetros analisados, considerado um nível de significância de $95 \%$.

O Índice de Qualidade de Água (IQA) corresponde a um número que varia de 0 a 100 , onde o cálculo foi executado de acordo com o que recomenda Von Sperling (2007), considerando nove parâmetros (temperatura, $\mathrm{pH}$, oxigênio dissolvido, demanda bioquímica de

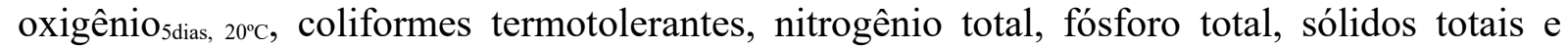
turbidez). A fórmula adaptada pela CETESB é indicada por Von Sperling (2007) para o cálculo de IQA (Equação 1).

$$
\mathrm{IQA}=\prod_{i=1}^{\mathrm{n}} \mathrm{q}_{\mathrm{i}}^{\mathrm{w}_{\mathrm{i}}}
$$

em que:

IQA: índice de qualidade de água, variando entre 0 e 100;

qi: qualidade do i-ésimo parâmetro, variando entre 0 e 100 de acordo com a curva média de variação de qualidade - uma função de sua medida ou concentração;

wi: peso correspondente ao i-ésimo parâmetro, variando entre 0 e 1; e

i: número do parâmetro, variando entre 1 e 9 ( $n=9$, que é o número de parâmetros envolvidos no cálculo de IQA).

A partir das fórmulas fornecidas por Von Sperling (2007), criou-se uma planilha para o cálculo das qualidades de cada parâmetro no software Excel, de modo a automatizá-lo.

\section{RESULTADOS E DISCUSSÃO}

\subsection{Análise de variância (ANOVA)}

As médias aritméticas e os desvios padrão estão relacionados na Tabela 1 para cada um dos parâmetros determinados das duas campanhas de coleta nos quatro pontos de amostragem. Segundo o teste estatístico ANOVA resumido na Tabela 2, são mostrados os resultados das análises de variância para cada um dos parâmetros analisados. Para todos os parâmetros, o F crítico das interações do fator ponto de coleta e para o fator sazonalidade foram 3,99; 2,748 e 2,748 , respectivamente. $\mathrm{Na}$ interpretação dos dados quando o $\mathrm{F}$ observado é menor que o $\mathrm{F}$ crítico, a hipótese nula é aceita, também comprovado quando o valor-p é menor que a probabilidade, que neste estudo é $\alpha=0,05$. 
Tabela 1. Médias (Med.), desvio padrão (DP) e número de valores (N) dos parâmetros analisados nas duas campanhas em quatro pontos de coleta.

\begin{tabular}{|c|c|c|c|c|c|c|c|c|c|c|c|c|}
\hline & \multicolumn{12}{|c|}{ Período menos chuvoso } \\
\hline & \multicolumn{3}{|c|}{ PONTO 1} & \multicolumn{3}{|c|}{ PONTO 2} & \multicolumn{3}{|c|}{ PONTO 3} & \multicolumn{3}{|c|}{ PONTO4 } \\
\hline & $\mathrm{N}$ & Med. & DP & $\mathrm{N}$ & Med. & DP & $\mathrm{N}$ & Med. & DP & $\mathrm{N}$ & Med. & DP \\
\hline $\mathrm{pH}$ & 9 & 7,02 & 0,25 & 9 & 7,01 & 0,16 & 9 & 7,18 & 0,05 & 9 & 7,04 & 0,21 \\
\hline $\mathrm{T}\left({ }^{\circ} \mathrm{C}\right)$ & 9 & 30,4 & 0,85 & 9 & 30,5 & 0,7 & 9 & 30,7 & 0,86 & 9 & 31,1 & 0,44 \\
\hline Cloreto (mg L ${ }^{-1}$ ) & 9 & 0,26 & 0,06 & 9 & 0,41 & 0,17 & 9 & 0,41 & 0,16 & 9 & 0,44 & 0,13 \\
\hline $\mathrm{CE}\left(\mu \mathrm{Scm}^{-1}\right)$ & 9 & 49,57 & 4,32 & 9 & 68,08 & 16,38 & 9 & 46,08 & 4,85 & 9 & 45,08 & 0,86 \\
\hline $\mathrm{STD}\left(\mathrm{mg} \mathrm{L}^{-1}\right)$ & 9 & 16,40 & 1,48 & 9 & 27,05 & 7,38 & 9 & 16,87 & 2,17 & 9 & 16,28 & 0,40 \\
\hline $\operatorname{Cor}\left(\mathrm{mgPt} \mathrm{L}^{-1}\right)$ & 9 & 46,83 & 8,12 & 9 & 35,46 & 3,68 & 9 & 42,43 & 3,20 & 9 & 35,56 & 4,21 \\
\hline $\mathrm{Na}\left(\mathrm{mg} \mathrm{L}^{-1}\right)$ & 9 & 2,89 & 0,29 & 9 & 6,79 & 3,80 & 9 & 2,68 & 0,53 & 9 & 2,69 & 0,19 \\
\hline $\mathrm{K} \mathrm{mg}\left(\mathrm{L}^{-1}\right)$ & 9 & 1,40 & 0,10 & 9 & 1,12 & 0,30 & 9 & 1,27 & 0,32 & 9 & 1,27 & 0,12 \\
\hline Alcalinidade $\left(\mathrm{mg} \mathrm{L}^{-1} \mathrm{CaCO}_{3}\right)$ & 9 & 16,36 & 1,09 & 9 & 17,57 & 1,35 & 9 & 18,51 & 1,18 & 9 & 18,11 & 0,98 \\
\hline Dureza $\left(\mathrm{mg} \mathrm{L}^{-1}\right)$ & 9 & 16,99 & 1,04 & 9 & 16,21 & 0,78 & 9 & 16,73 & 0,78 & 9 & 17,52 & 1,71 \\
\hline \multirow[t]{2}{*}{ Cálcio (mg L-1) } & 9 & 1,89 & 0,79 & 9 & 2,13 & 0,39 & 9 & 2,59 & 0,75 & 9 & 2,51 & 0,27 \\
\hline & \multicolumn{12}{|c|}{ Período chuvoso } \\
\hline $\mathrm{pH}$ & 9 & 7,34 & 0,17 & 9 & 7,39 & 0,03 & 9 & 7,31 & 0,03 & 9 & 7,22 & 0,04 \\
\hline $\mathrm{T}\left({ }^{\circ} \mathrm{C}\right)$ & 9 & 29,4 & 0,32 & 9 & 29,8 & 0,47 & 9 & 30,1 & 0,39 & 9 & 30,1 & 0466 \\
\hline Cloreto (mg L ${ }^{-1}$ ) & 9 & 0,23 & 0,05 & 9 & 0,42 & 0,05 & 9 & 0,38 & 0,05 & 9 & 0,37 & 0,04 \\
\hline $\mathrm{CE}\left(\mu \mathrm{Scm}^{-1}\right)$ & 9 & 35,77 & 2,56 & 9 & 42,60 & 2,50 & 9 & 43,22 & 2,91 & 9 & 43,09 & 2,14 \\
\hline $\operatorname{STD}\left(\mathrm{mg} \mathrm{L}^{-1}\right)$ & 9 & 10,38 & 0,70 & 9 & 12,66 & 0,43 & 9 & 13,35 & 1,25 & 9 & 12,76 & 0,58 \\
\hline Cor $\left(\mathrm{mgPt} \mathrm{L}^{-1}\right)$ & 9 & 59,40 & 12,51 & 9 & 48,29 & 2,87 & 9 & 50,21 & 4,02 & 9 & 96,11 & 5,42 \\
\hline $\mathrm{Na}\left(\mathrm{mg} \mathrm{L}^{-1}\right)$ & 9 & 1,54 & 0,21 & 9 & 2,83 & 0,41 & 9 & 3,28 & 1,58 & 9 & 3,40 & 0,44 \\
\hline $\mathrm{K}\left(\mathrm{mg} \mathrm{L}^{-1}\right)$ & 9 & 1,27 & 0,41 & 9 & 1,58 & 0,20 & 9 & 1,59 & 0,41 & 9 & 1,96 & 0,29 \\
\hline Alcalinidade $\left(\mathrm{mg} \mathrm{L}^{-1}\right)$ & 9 & 17,44 & 1,45 & 9 & 16,70 & 0,96 & 9 & 17,03 & 1,02 & 9 & 17,71 & 1,41 \\
\hline Dureza $\left(\mathrm{mg} \mathrm{L}^{-1}\right)$ & 9 & 12,55 & 1,18 & 9 & 14,64 & 1,04 & 9 & 14,38 & 0,78 & 9 & 14,64 & 1,04 \\
\hline Cálcio (mg L-1) & 9 & 0,57 & 0,1 & 9 & 0,82 & 0,08 & 9 & 0,78 & 0,14 & 9 & 0,81 & 0,08 \\
\hline
\end{tabular}

$\mathrm{O}$ pH é uma variável abiótica importante nos ecossistemas aquáticos de difícil interpretação pela quantidade de fatores que o podem afetar (Esteves, 2011). O valor médio do $\mathrm{pH}$ foi de 7,01 a 7,18 no período menos chuvoso, e de 7,22 a 7,39 no período chuvoso como 
mostrado na Tabela 1. Embora os valores do $\mathrm{pH}$ estejam na faixa da neutralidade, para o período menos chuvoso os valores de $\mathrm{pH}$ são mais baixos que na época de chuva, como pode ser observado na Figura 2(a). Estes teores são maiores se comparados com os valores obtidos por Pereira et al. (2007) no Rio Murucupi no mesmo município com características ácidas e valores entre 4,35 a 6,15. Pontes et al. (2012), observaram na microbacia do Córrego Banguelo no Estado de Minas Gerais que a maioria dos pontos monitorados apresentou água mais ácida também no período de chuvas, o que pode estar associada ao aumento no teor de ácidos orgânicos. Resultados similares também foram encontrados por Santi et al. (2012) no Igarapé São Francisco, no Estado do Acre, durante o período de alta pluviosidade. Os autores enfatizam que os resultados são explicados pelo fato das águas da precipitação atmosférica serem mais ácidas. Porém, deve-se considerar a descrição de Sioli $(1956 ; 1957 ; 1960)$ dos rios amazônicos em estado natural que apresentam diferentes valores de $\mathrm{pH}$. Assim, os rios de águas brancas estão entre 6,2 e 7,2, os rios de águas claras entre 4,5 e 7,8 e os rios de águas pretas entre 3,8 e 4,9. Por outro lado, os valores de $\mathrm{pH}$ podem ser alterados ao longo do rio, caso concreto do Rio Amazonas, que de um $\mathrm{pH}$ de 4,0 eleva-se até 7,8 praticamente no encontro com águas marinhas (Esteves, 2011). Segundo o teste ANOVA, a localização dos pontos não tem influência significativa no valor médio do $\mathrm{pH}$ aceitando a hipótese nula. Estudos realizados na área mostram que o $\mathrm{pH}$ é influenciado pela maré, pois pode funcionar como agente depurador nos rios da região quando estes são afetados por descargas de efluentes (Pereira et al., 2007). Entretanto, a sazonalidade e a sua interação com o fator "ponto de amostragem", estatisticamente, têm influência significativa nos teores médios do $\mathrm{pH}$, aceitando as hipóteses alternativas. De acordo com Von Sperling (2007), fatores naturais como a dissolução de rochas e a fotossíntese, ou fatores antrópicos como os esgotos domésticos e industriais afetam o $\mathrm{pH}$. Segundo Silva (2008), com o aumento das chuvas o $\mathrm{pH}$ tende a subir, pois aumenta a diluição de compostos dissolvidos e há um escoamento maior. Na maioria das águas naturais, o sistema carbonato controla o pH (Drever, 1988). Esteves (2011) afirma que as reações de íons carbonato e bicarbonato com a molécula de água elevam o pH. Em um estudo de Miranda et al. (2009), realizado no rio Tapajós em Santarém- PA, encontraram teores de $\mathrm{pH}$ entre 6,6 e 7,8, concluindo conformidade com a legislação estabelecida pelo CONAMA 357. Outro estudo realizado por Alves et al. (2012) em águas superficiais no rio Arari na ilha de Marajó-PA, encontraram inconformidades com a legislação nos valores de $\mathrm{pH}$ que estavam entre 3,3 e 6,22. Os teores de $\mathrm{pH}$ do presente estudo estão dentro dos padrões permitidos pelo CONAMA/357 para águas doces classes I, II e III, que aceita valores entre a faixa de 6,0 a 9,0 (CONAMA, 2005).

Segundo Boesch (2002) e Esteves (2011), a condutividade elétrica é um parâmetro que pode mostrar modificações na composição dos corpos d'água, mas não especifica quantidades e componentes. É um parâmetro importante para controlar e determinar o estado e a qualidade de água (Piñeiro Di Blasi et al., 2013). Existe uma correlação estatística entre a condutividade da água e a concentração de diversos elementos e íons (Tundisi e Matsumura-Tundisi, 2008). De acordo com Esteves (2011), nas regiões tropicais a condutividade está relacionada com as características geoquímicas da região e condições climáticas (periodicidade de precipitações). Rios que podem ter a mesma nascente e diferentes drenagens apresentam diferenças na condutividade elétrica (Frančišković-Bilinski, et al. 2013). Os resultados na área de estudo mostraram que os teores de condutividade mudam de 45,08 a $68,08 \mu \mathrm{S} \mathrm{cm}^{-1}$ no período menos chuvoso e de 35,77 a $43,22 \mu \mathrm{S} \mathrm{cm}^{-1}$ no período chuvoso (Tabela 1). Na Figura 2 (b) pode ser observado que no período menos chuvoso, os teores da condutividade são maiores especialmente no ponto P-02 mais próximo do pólo industrial de Barcarena e com maior influência dos efluentes lançados pelas indústrias e pela comunidade da Vila do Conde. O uso do solo pode modificar diretamente a composição de uma água refletindo-se na condutividade elétrica (Esteves, 2011, 1998; Von Sperling, 2005). Por meio das análises estatísticas, 
comprovou-se que a sazonalidade, a localização dos pontos de amostragem e a interação entre eles afetam significativamente os teores médios da condutividade elétrica, rejeitando as hipóteses nulas. Segundo Esteves (2011), a condutividade elétrica muda com a sazonalidade sendo menor no período chuvoso por causa do aumento do fator de diluição dos íons, não obstante o lançamento de efluentes industriais poderem elevar os valores da condutividade elétrica independentemente da sazonalidade. Não existe um padrão de condutividade na legislação, porém, de acordo com Von Sperling (2007), as águas naturais apresentam teores de condutividade na faixa de 10 a $100 \mu \mathrm{S} \mathrm{cm}^{-1}$, e em ambientes poluídos por esgotos domésticos ou industriais os valores podem chegar até $1000 \mu \mathrm{S} \mathrm{cm}^{-1}$. Em um estudo realizado por Alvarenga et al. (2012) em uma microbacia afluente do Rio Paraíba do Sul- SP, em um período chuvoso e dois não chuvosos reportaram valores de condutividade de 26,00 a $50,10 \mu \mathrm{S} \mathrm{cm}^{-1}$; neste estudo observou-se que um dos períodos secos apresentou baixos teores de condutividade comparado com os outros períodos de coleta. Em uma avaliação da qualidade da água realizado por Marmontel e Rodrigues (2015) em nascentes de diferentes coberturas vegetais no Córrego Pimenta- SP encontraram teores de 10,7 a $139,0 \mu \mathrm{S} \mathrm{cm}^{-1}$ no período seco e de 13,2 a $149,0 \mu \mathrm{S} \mathrm{cm}^{-1}$ no período chuvoso, mostrando um comportamento similar aos deste estudo, encontrando os maiores teores no período chuvoso. Valores médios reportados por Sioli (1984) da condutividade em três rios da região Amazônica foram de $57 \mu \mathrm{S} \mathrm{cm}^{-1}$ para o Rio Solimões, $22 \mu \mathrm{Scm}^{-1}$ para o Rio Negro e $21 \mu \mathrm{Scm}^{-1}$ para o Rio Tarumã-Mirim. Nos dois últimos casos, os valores são inferiores se comparados com os teores médios obtidos no presente estudo.

A temperatura é o parâmetro que faz a medição da intensidade de calor, refletindo o grau de aquecimento das águas e da radiação solar, e depende de fatores como clima, composição geológica, condutividade elétrica das rochas, dentre outras (Matic et al., 2013). Os teores médios da temperatura neste estudo para o período menos chuvoso estão entre 30,4 a $31,1^{\circ} \mathrm{C}$, e para o período chuvoso entre 29,4 e $30,1^{\circ} \mathrm{C}$ (Tabela 1), mostrando uma estabilidade durante todo o ano característico da região equatorial (Esteves, 2011; Matic et al., 2013). Estatisticamente, a localização e a sazonalidade tiveram influência significativa nos teores médios da temperatura aceitando as hipóteses alternativas como pode ser visto na Tabela 2 . Porém, a interação entre eles não tem influência aceitando a hipótese nula. Entre as duas campanhas de coleta pode ser observado uma variação de $1^{\circ} \mathrm{C}$ sendo maior no período menos chuvoso conforme a Figura 2 (c). As variações de temperatura nos corpos d'água naturais podem ser sazonais e diurnas de acordo com estudos de Sá Filho (2010) e estão associadas com as estações do ano - Bucci et al. (2015). Assim, estudos realizados em regiões que apresentam maior variação sazonal da temperatura influenciam na temperatura dos corpos hídricos, como o de Souza et al. (2015) que em um trecho da bacia Ribeirão Ubá- MG encontraram teores que variavam de 20,6 até $24^{\circ} \mathrm{C}$ e a elevação da temperatura da água foi correlacionada com a temperatura do ar. Na época de maior precipitação, a nebulosidade aumenta e dificulta a entrada dos raios solares às superfícies dos corpos d'água, o que não sucede no período menos chuvoso, pois o tempo de incidência dos raios solares é maior (Sá Filho, 2010). A temperatura é um parâmetro que também permite determinar se há poluição térmica pela descarga de efluentes (Von Sperling, 2007; Sanchez, 2006). Como diversos corpos hídricos são receptores de efluentes, a resolução do CONAMA 430 estabelece como temperatura máxima para o lançamento de efluentes, $40^{\circ} \mathrm{C}$. Observou-se que nos pontos de amostragem (CONAMA, 2011), o ponto P-01 tem um teor médio menor que nos pontos P-02, P-03 e P-04, pontos estes que estão localizados em áreas abertas e livres da influência vegetal, que poderiam impedir a entrada dos raios solares. Para Madden et al. (2013) as descargas de efluentes mudam a temperatura dos ecossistemas aquáticos representando ameaça para a biota aquática. Por outro lado, na coluna d'água a temperatura diminui com a profundidade de um corpo hídrico e tem correlação com outros parâmetros (Malheiros et al., 2012).

Rev. Ambient. Água vol. 12 n. 3 Taubaté - May / Jun. 2017 
Tabela 2.Teste estatístico ANOVA de um fator F.

\begin{tabular}{|c|c|c|c|c|c|c|c|c|c|}
\hline & \multicolumn{3}{|c|}{ Interações } & \multicolumn{3}{|c|}{ Sazonalidade } & \multicolumn{3}{|c|}{ Pontos } \\
\hline & $\mathrm{F}$ & valor-p & $\begin{array}{l}\text { Hipótese } \\
\text { aceita }\end{array}$ & $\mathrm{F}$ & valor-p & $\begin{array}{c}\text { Hipótese } \\
\text { aceita }\end{array}$ & $\mathrm{F}$ & valor-p & $\begin{array}{c}\text { Hipótese } \\
\text { aceita }\end{array}$ \\
\hline $\mathrm{pH}$ & 2,96 & $3,88 \mathrm{E}-02$ & $\mathrm{H}_{1}$ & 54,23 & $4,26 \mathrm{E}-10$ & $\mathrm{H}_{1}$ & 1,84 & $1,50 \mathrm{E}-01$ & $\mathrm{H}_{0}$ \\
\hline Temper. & 0,51 & 0,67 & $\mathrm{H}_{0}$ & 39,62 & $3,16 \mathrm{E}-08$ & $\mathrm{H}_{1}$ & 4,84 & 0,004 & $\mathrm{H}_{1}$ \\
\hline Cloreto & 0,49 & $7,83 \mathrm{E}-01$ & $\mathrm{H}_{0}$ & 1,44 & $2,89 \mathrm{E}-01$ & $\mathrm{H}_{0}$ & 10,71 & $1,52 \mathrm{E}-05$ & $\mathrm{H}_{1}$ \\
\hline $\mathrm{CE}$ & 12,99 & $1,001 \mathrm{E}-06$ & $\mathrm{H}_{1}$ & 51,97 & $7,999 \mathrm{E}-10$ & $\mathrm{H}_{1}$ & 14,51 & $2,57 \mathrm{E}-07$ & $\mathrm{H}_{1}$ \\
\hline STD & 14,92 & $1,80 \mathrm{E}-07$ & $\mathrm{H}_{1}$ & 105,74 & $3,47 \mathrm{E}-15$ & $\mathrm{H}_{1}$ & 18,21 & $1,18 \mathrm{E}-08$ & $\mathrm{H}_{1}$ \\
\hline Cor & 70,03 & $3,46 \mathrm{E}-20$ & $\mathrm{H}_{1}$ & 248,96 & $9,71 \mathrm{E}-24$ & $\mathrm{H}_{1}$ & 49,45 & $1,17 \mathrm{E}-16$ & $\mathrm{H}_{1}$ \\
\hline $\mathrm{Na}$ & 9,69 & 2,32E-05 & $\mathrm{H}_{1}$ & 8,06 & 0,006 & $\mathrm{H}_{1}$ & 9,79 & $2,1 \mathrm{E}-05$ & $\mathrm{H}_{1}$ \\
\hline $\mathrm{K}$ & 6,31 & $8,07 \mathrm{E}-04$ & $\mathrm{H}_{1}$ & 23,43 & $8,52 \mathrm{E}-06$ & $\mathrm{H}_{1}$ & 3,41 & $2,26 \mathrm{E}-02$ & $\mathrm{H}_{1}$ \\
\hline Alcal. & 3,75 & $1,52 \mathrm{E}-02$ & $\mathrm{H}_{1}$ & 2,23 & $1,40 \mathrm{E}-01$ & $\mathrm{H}_{0}$ & 3,01 & $3,66 \mathrm{E}-02$ & $\mathrm{H}_{1}$ \\
\hline Dureza & 5,66 & $1,67 \mathrm{E}-03$ & $\mathrm{H}_{1}$ & 121,25 & $2,07 \mathrm{E}-16$ & $\mathrm{H}_{1}$ & 4,44 & $6,77 \mathrm{E}-03$ & $\mathrm{H}_{1}$ \\
\hline Cálcio & 1,49 & $2,27 \mathrm{E}-1$ & $\mathrm{H}_{0}$ & 235,84 & $3,85 \mathrm{E}-23$ & $\mathrm{H}_{1}$ & 4,27 & $8,23 \mathrm{E}-3$ & . \\
\hline
\end{tabular}

Nota: hipóteses nulas: Ho1 - não há efeito pela sazonalidade (duas campanhas de coleta), Ho2- não há efeito entre os quatro pontos de amostragem e Ho3 - não há combinação entre os efeitos sazonalidade e pontos de amostragem. Hipóteses alternativas: $\mathrm{H}_{1}$ - há efeito em cada um dos três casos.

Os sólidos totais dissolvidos (STD) estão relacionados diretamente com a condutividade elétrica (Araújo e Oliveira, 2013; Esteves, 2011, 1998; Tundisie e Matsumura Tundisi, 2008) e é usada em laboratório de rotina como medida da salinidade da água e/ ou dos efeitos causados por alguma atividade antrópica que afete um corpo d'água (Van Niekerk et al., 2014). Os STD, ao serem relacionados com a condutividade elétrica e quando não podem ser medidos, é usado um fator de conversão como no estudo realizado por Frančišković-Bilinski, et al. (2013) que multiplicou por 0,67 e desta forma calculou os STD das nascentes que estudaram. Os teores médios dos STD no estudo são resumidos na Tabela 1 , com valores de 16,28 a 27,05 mg L $\mathrm{m}^{-1}$ para o período menos chuvoso e de 10,38 a $13,35 \mathrm{mg} \mathrm{L}^{-1}$ no período chuvoso. Em águas continentais, os STD variam em relação à hidrogeoquímica regional e das drenagens de rochas ígneas ou sedimentares (Tundisi e Matsumura Tundisi, 2008). Os STD incluem todos os sais e componentes não iônicos. Os processos de intemperismo geram produtos que são encontrados nos corpos da água na forma iônica, que são os principais constituintes dos STD. Este parâmetro é utilizado no controle de poluição de corpos d'água natural com esgotos sanitários e efluentes industriais, para avaliar a eficiência nas estações de tratamentos de efluentes como Marimuthu et al. (2013) em Tamilnadu na Índia. Os resultados obtidos mostram que o ponto P-02 no período menos chuvoso tem o teor mais elevado de STD (Figura 2(d)), deduzindo que as atividades industriais da área estão impactando os corpos receptores. Os teores médios de STD obtidos no presente estudo foram menores a $500 \mathrm{mg} \mathrm{L}^{-1}$, padrão de qualidade da resolução CONAMA 357 para águas doces classe I, II e III (CONAMA, 2005). Em um estudo de Barreto et al. (2014), foram medidos os teores de STD e avaliada a relação entre a vazão e a qualidade da água numa seção do Rio Catolé Grande-BA, onde observou-se um aumento dos STD ao aumentar a vazão do rio. A cor é uma característica física da água devido à existência de substâncias dissolvidas, ou em estado coloidal, na maioria dos casos de natureza orgânica (NBR 9896/1993). A cor é um parâmetro a ser avaliado segundo a legislação, em estudos da qualidade da água para potabilidade (Santos et al., 2015). Os valores médios obtidos da cor

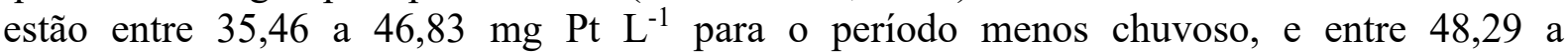
$96,11 \mathrm{mg} \mathrm{Pt} \mathrm{L}^{-1}$ para o período chuvoso (Tabela 1). Estatisticamente, a sazonalidade, a localização dos pontos de amostragem e a interação entre os dois fatores têm influência significativa no valor médio da cor rejeitando as hipóteses nulas (Tabela 2). Com o aumento das chuvas, aumenta o transporte de material orgânico e inorgânico drenado nas margens dos 
rios, o que influência um aumento na cor. As ligninas, taninos, substâncias húmicas e fúlvicas, algas e entre outras, provenientes da decomposição de material orgânico, principalmente de origem vegetal, são causadoras da cor em águas naturais (CETESB, 2012; León, 2005). Além disso, estas substâncias podem estar em solução originando a cor verdadeira ou em suspensão originando a cor aparente (USEPA, 2015; León, 2005; Esteves, 1998). Na Figura 2 (e) pode ser observado que os maiores teores correspondem à época mais chuvosa. Segundo Von Sperling (2007), as atividades antrópicas influem na constituição da cor na água pelo lançamento de efluentes domésticos e/ou industriais nos corpos d'agua, e de acordo com Skoronski et al., (2014) é um parâmetro indicador na avaliação da eficiência dos processos nas estações de tratamento de efluente. Segundo a CETESB, o esgoto doméstico se caracteriza por apresentar matéria orgânica coloidal. Outros constituintes de origem natural que causam a coloração na água são minerais dissolvidos como o ferro e manganês relacionados com a geologia dos solos das margens dos rios (CETESB, 2012; Von Sperling, 2007; León, 2005).
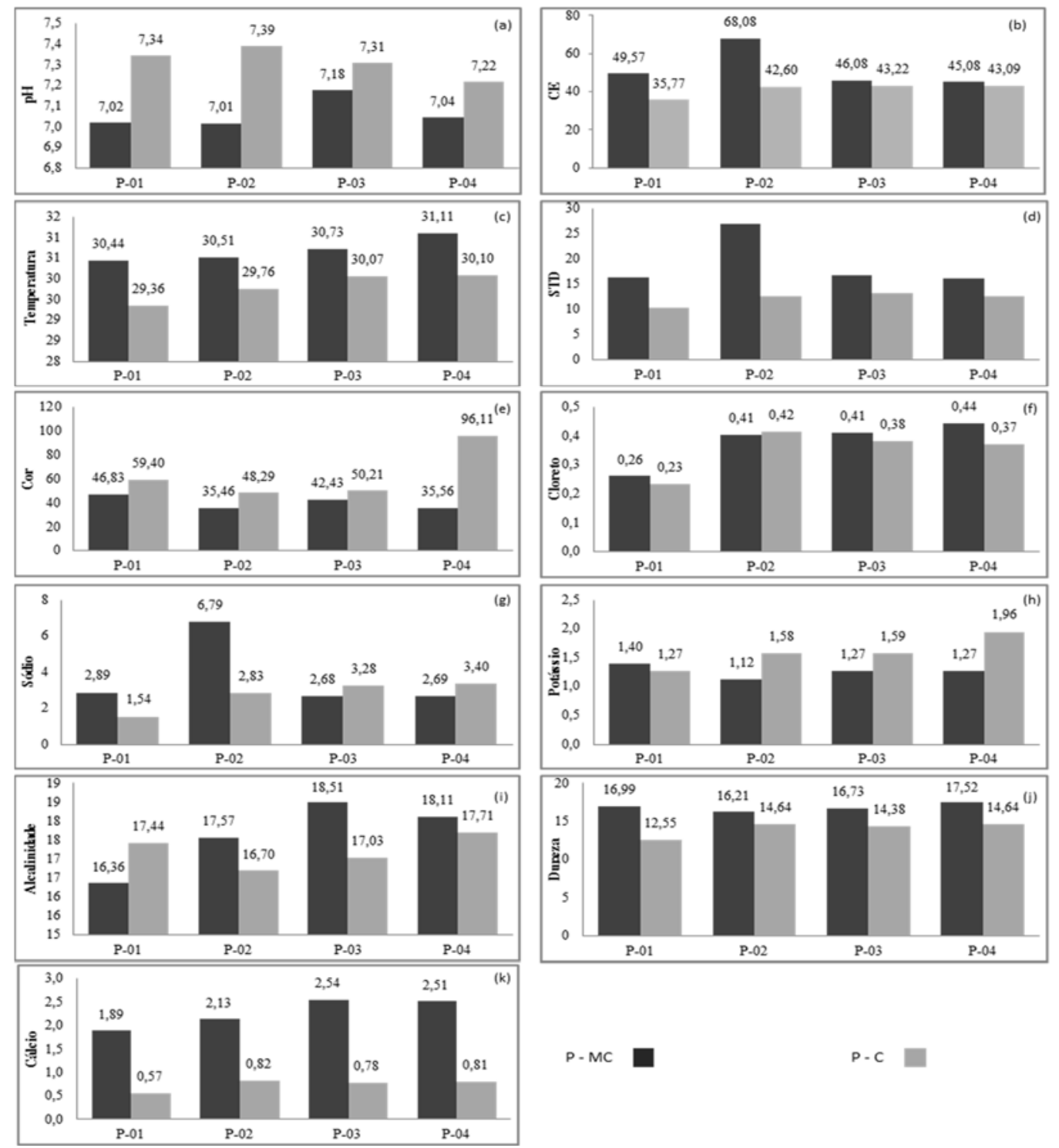

Figura 2. Distribuição dos teores médios dos parâmetros analisados: (a)pH, (b) Condutividade elétrica (CE) $\mu \mathrm{S} . \mathrm{cm}^{-1}$, (c) Temperatura ${ }^{\circ}$ C, (d) STD $\mathrm{mg} \mathrm{L}^{-1}$, (e) Cor, (f) Cloreto $m g \mathrm{~L}^{-1}$, (g) Sódio $\mathrm{m} \mathrm{L}^{-1}$, (h) Potássio $\mathrm{mg} \mathrm{L}^{-1}$, (i) Alcalinidade $m g \mathrm{~L}^{-1}$, (j) Dureza $\mathrm{mg} \mathrm{L}^{-1}$, (k) Cálcio $\mathrm{mg} \mathrm{L}^{-1}$. Ponto 1 (P-01), Ponto 2 (P-02), Ponto 3 (P-03), Ponto 4 (P-04), Período menos chuvoso (P- MC), Período chuvoso (P- C). 
O padrão estabelecido na resolução CONAMA 357 (2005) para a cor é de até $75 \mathrm{mg} \mathrm{Pt} \mathrm{L}{ }^{-1}$. Na Figura 2 (e) pode ser observado que no período menos chuvoso os quatro pontos de coleta estão dentro do padrão, porém no período chuvoso o ponto P-04 ultrapassa este limite (Tabela 1). Isto pode ser devido às atividades antrópicas realizadas nas margens do corpo hídrico em conjunto com o aumento da descarga hídrica. No trabalho Fonseca e Salvador (2005), também encontraram uma relação no aumento das unidades de cor no período de chuva, se comparado com o período menos chuvoso na Bacia hidrográfica do Rio Bonito- SP. A presença da cor na água nem sempre representa risco à saúde, mas a população pode questionar a qualidade da água (CETESB, 2012). O trabalho de Fonseca e Salvador (2005) mostra uma relação no aumento das unidades de cor no período de chuva, se comparado com o período menos chuvoso na Bacia hidrográfica do Rio Bonito- SP. Soares et al. (2009) obtiveram valores da cor fora dos padrões estabelecidos pelo CONAMA 357 (2005) em um estudo realizado no rio Águas Claras em Alvorada - RO, os quais estavam entre a faixa de 160 a $250 \mathrm{mg} \mathrm{Pt} \mathrm{L}{ }^{-1}$. Na caracterização de parâmetros do manancial Utinga na cidade de Belém-PA, Vasconcelos e Souza (2011) encontraram valores médios mensais nos anos 2007, 2008 e 2009 da cor de 53,89, 74,12 e 74,12 mg Pt L ${ }^{-1}$ respectivamente. Ainda que estes valores médios estejam enquadrados nos padrões legalmente permitidos, foi observado um aumento dos valores de um ano para o outro, o qual pode ser relacionado a um aumento das atividades antrópicas na região.

O cloreto é um íon importante nas águas subterrâneas e superficiais, podendo ter origem antrópica e geológica, sendo a lixiviação de rochas, esgotos domésticos e industriais a sua principal origem (USEPA, 2015). Segundo a CETESB (2012), uma pessoa expele na urina aproximadamente $4 \mathrm{~g}$ de cloreto por dia. O cloreto é um íon importante na produtividade global dos ecossistemas aquáticos, faz parte de importantes processos fisiológicos como a troca e/o transporte de outros íons para os meios intracelular e extracelular. Os teores médios da concentração de cloreto no período menos chuvoso foram de 0,26 a $0,44 \mathrm{mg} \mathrm{L}^{-1}$, e no período chuvoso está entre 0,23 e $0,42 \mathrm{mg} \mathrm{L}^{-1}$ (Tabela 1). Segundo o teste estatístico ANOVA (Tabela 2), não existiu evidência significativa de que a sazonalidade tenha um efeito na média dos valores aceitando a hipótese nula. A localização dos pontos de amostragem apresenta diferenças significativas no teor médio do cloreto aceitando a hipótese alternativa. Isto possivelmente se dá pelo lançamento de efluentes industriais, já que como descreve a CETESB (2012) e Von Sperling (2007), os efluentes também aportam quantidades consideráveis de cloreto dependendo do tipo de beneficiamento industrial. Na Figura 2 (f) pode ser observado que o ponto P-01 tem os valores médios mais baixos nas duas coletas. A interação dos dois fatores não tem efeito significativo nos teores médios do cloreto. Os teores de cloreto em ecossistemas continentais são extremamente variáveis. Em águas naturais, o teor do íon cloreto é menor que $50 \mathrm{mg} \mathrm{L}^{-1}$ (Rodier, 1981), e podem ser afetados pela entrada da pluma das correntes marinhas nos corpos de águas costeiras (Esteves, 2011; Hem, 1970), que podem conferir um sabor salgado à água ou propriedades laxativas (Lucas et al., 2014). Dados de Sioli (1984) mostram concentrações médias de cloreto dos rios Solimões, Negro e Tarumã-Mirim de $3,1 \mathrm{mg} \mathrm{L}^{-1} 1,7 \mathrm{mg} \mathrm{L}^{-1}$ e de 1,8 $\mathrm{mg} \mathrm{L}^{-1}$, respectivamente; Siqueira et al. (2012) em um diagnóstico do Rio Parauapebas- PA, encontraram teores de $0,40 \mathrm{mg} \mathrm{L}^{-1}$ de $\mathrm{Cl}^{-}$demonstrando que as concentrações baixas são comuns nos rios Amazônicos. A média mundial das concentrações de cloreto é de $7,8 \mathrm{mg} \mathrm{L}^{-1}$ (Esteves, 2011). Estudos em outras regiões encontraram concentrações de cloreto de 4,43 a 299,26 $\mathrm{mg} \mathrm{L}^{-1} \mathrm{Cl}^{-}$(Lucas et al., 2014) no Riacho Jacaré em Sergipe, e em uma avaliação da qualidade sazonal das águas, Ribeiro et al. (2013) em função ao lançamento de efluentes de abate bovino, reportaram teores de 0,08 a $1,84 \mathrm{mg} \mathrm{L}^{-1} \mathrm{Cl}^{-}$no período seco e de 0,34 a $1,39 \mathrm{mg} \mathrm{L}^{-1} \mathrm{Cl}^{-}$no período chuvoso; Souza et al. (2015) reportaram teores de 19,3 a 35,4 $\mathrm{mg} \mathrm{L}^{-1} \mathrm{Cl}^{-}$. Desta forma observa-se que diversos fatores afetam a concentração de cloreto nos corpos d'água. Nos padrões de enquadramento das águas doces no CONAMA 357, o valor máximo permitido de cloreto é de $250 \mathrm{mg} \mathrm{L}^{-1}$ para águas 
doces classe I, II e III, e os resultados obtidos neste estudo se enquadram nesta normativa (CONAMA, 2005). Contudo, em caracterizações gerais de recursos hídricos, o cloreto é um componente encontrado naturalmente em análises de rotina (Alfaro, 2014).

O sódio é um dos elementos encontrado em maior abundância na Terra, sendo solúvel em água (Lucas et al., 2014). Segundo a USEPA (2015) o sódio pode entrar nos corpos d'água por fontes naturais ou antrópicas. No primeiro caso pode ser por lixiviação das rochas e no segundo caso por esgotos sanitários, efluentes industriais e/ou atividades agrícolas (CETESB, 2012; Von Sperling, 2007). As concentrações de sódio obtidas no estudo no período menos chuvoso compreende teores médios de 2,68 a $6,79 \mathrm{mg} \mathrm{L}^{-1}$, e no período chuvoso estão entre 1,54 e $3,40 \mathrm{mg} \mathrm{L}^{-1}$ (Tabela 1). A sazonalidade, a localização dos pontos de amostragem e a interação entre os dois fatores têm influência significativa nos teores médios do sódio rejeitando as hipóteses nulas nos três casos. Nos ecossistemas aquáticos costeiros, o aumento na concentração de sódio pode ser influenciado pela entrada de águas marinhas (CETESB, 2012; Esteves, 2011; Tundisi e Matsumura Tundisi, 2008; Rodier, 1981). Segundo a CETESB (2012), as concentrações de sódio em águas superficiais variam consideravelmente por fatores como a geologia do local, as descargas de efluentes, o uso sazonal de sais nas rodovias e o uso de fertilizantes na agricultura. De acordo com Fittkau et al. (1975), a média do sódio do Rio Amazonas varia entre 1,15 a 2,90 $\mathrm{mg} \mathrm{L}^{-1}$. No estudo de Ribeiro et al. (2013) no ponto de amostragem com influência de lançamento de efluentes de abate bovino encontraram concentrações de sódio de 14,52 a 197,5 $\mathrm{mg} \mathrm{L}^{-1}$ para o período seco, e de 11,33 a 189,38 mg L-1 no período chuvoso, sendo que as maiores concentrações foram encontradas na jusante do córrego, apontando um comportamento similar, com concentração do sódio com menores teores obtidos no período chuvoso.

Pode ser observado na Figura 2 (g) que os teores médios mais elevados correspondem ao período menos chuvoso, possivelmente pela influência de correntes oceânicas no trecho do rio estudado. Entretanto, o ponto P-02 apresentou o teor de sódio mais elevado no período seco, devido provavelmente a impactos ambientais do local. Segundo a CETESB (2012), os valores podem estender-se de $1 \mathrm{mg} \mathrm{L}^{-1}$ ou menos, até $10 \mathrm{mg} \mathrm{L}^{-1}$. Muitas águas superficiais incluindo aquelas que recebem efluentes têm níveis bem abaixo de $50 \mathrm{mg} \mathrm{L}^{-1}$.

O potássio é um elemento que está em baixas concentrações nas águas naturais, sendo a lixiviação das rochas a sua principal fonte natural. Portanto, a fonte antrópica é uma das suas fontes, visto que é um elemento utilizado na indústria e na agricultura (Zuin et al., 2009). Uma importante função do potássio é a troca e transporte de outros íons para os meios intracelular e extracelular (Esteves, 2011). Os resultados do presente estudo mostraram que a concentrações médias de potássio obtidas foram de 1,27 a $1,96 \mathrm{mg} \mathrm{L}^{-1}$ para o período chuvoso, e,de 1,12 a $1,40 \mathrm{mg} \mathrm{L}^{-1}$ para o período menos chuvoso (Tabela 1). Estes teores encontrados foram maiores se comparados com valores obtidos por Ferch (1984) no Rio Solimões (valores de 0,9 $\mathrm{mg} \mathrm{L}^{-1}$ ) e no rio Negro $\left(0,3 \mathrm{mg} \mathrm{L}^{-1}\right)$. No entanto, o mesmo autor estudou o lago Camaleão, localizado no interior da ilha da Marchantaria no rio Solimões (AM), e observaram alterações na concentração do potássio em função da variação do nível de água. No período de águas baixas, a concentração foi aproximadamente 15 vezes o valor obtido no rio Solimões, já que na enchente o rio invade as águas do lago efetuando uma diluição, refletindo na redução de concentração de potássio. Na Figura 2 (h) pode ser observado que os maiores valores correspondem à época chuvosa. Estatisticamente, a sazonalidade da localização dos pontos de amostragem e a interação destes fatores têm influência significativa nos teores médios do potássio rejeitando as hipóteses nulas (Tabela 2). Com relação à localização dos pontos de amostragem, deve-se ter em conta que as concentrações elevadas de potássio são principalmente encontradas em águas residuais (Monaco, 2011). De acordo com Alfaro (2014), o potássio é dos poucos compostos encontrados naturalmente em corpos d'água. Está

Rev. Ambient. Água vol. 12 n. 3 Taubaté - May / Jun. 2017 
distribuído amplamente no ambiente. Desta forma, as concentrações de água bruta e potável de diferentes partes do Canadá variam de $<1$ a $8 \mathrm{mg} \mathrm{L}^{-1}$. Entretanto na Província de Saskatchewan as concentrações estão acima de $51 \mathrm{mg} \mathrm{L}^{-1}$, onde possui um dos maiores depósitos de potássio do mundo (CETESB, 2012). Segundo Esteves (2011), as concentrações médias de potássio em rios de América do Sul são de $2 \mathrm{mg} \mathrm{L}^{-1}$.

A alcalinidade nas águas naturais, responsável pela capacidade de neutralização de ácidos, geralmente apresenta como principais responsáveis: bases conjugadas de ácido carbônico, carbonatos e bicarbonatos; outras bases derivadas do íon amônio e dos ácidos sulfúrico e fosfórico também podem contribuir para a alcalinidade (Esteves, 2011; Hem, 1970). Os teores médios da alcalinidade no período menos chuvoso foram de 16,36 a $18,51 \mathrm{mg} \mathrm{L}^{-1}$ de $\mathrm{CaCO}_{3}$, e

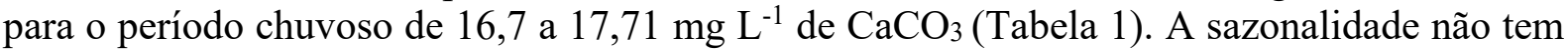
influência significativa no valor médio da alcalinidade (Tabela 2), embora para os fatores da localização dos pontos de amostragem e sua interação com a sazonalidade, observou-se evidência significativa para afirmar que eles afetam os teores médios da alcalinidade. Pode ser observado na Figura 2 (i), com exceção do ponto P-01, a alcalinidade foi maior para o período menos chuvoso. A alcalinidade não tem um significado sanitário, com exceção de quando ela ocorre devido a hidróxidos, ou quando contribua na qualidade de sólidos totais. Segundo a Secretaria de Vigilância em Saúde (Brasil, 2006), a maioria das águas naturais apresenta valores de alcalinidade na faixa de 30 a $500 \mathrm{mg} \mathrm{L}^{-1}$ de $\mathrm{CaCO}_{3}$. No presente estudo os valores são inferiores, e característicos de rios amazônicos.

A dureza é a concentração de cátions multimetálicos em solução. Os cátions frequentemente associados à dureza são cálcio e magnésio $\left(\mathrm{Ca}^{2+}, \mathrm{Mg}^{2+}\right)$, e em menor escala ferro $\left(\mathrm{Fe}^{2+}\right)$, manganês $\left(\mathrm{Mn}^{2+}\right)$, estrôncio $\left(\mathrm{Sr}^{2+}\right)$ e alumínio $\left(\mathrm{Al}^{3+}\right)$ (USEPA, 2015; Brasil, 2006). Segundo a UNEP (2008) a dureza é influenciada pela geologia da bacia de drenagem e por atividades antrópicas. As principais fontes de dureza são a dissolução de minerais contendo cálcio e magnésio, exemplificando, as rochas calcárias e os despejos industriais (Von Sperling, 2007). Os valores da dureza mudaram entre 16,21 e $17,52 \mathrm{mg} \mathrm{L}^{-1}$ de $\mathrm{CaCO}_{3}$ para o período menos chuvoso e 12,55 a 12,64 $\mathrm{mg} \mathrm{L}^{-1}$ de $\mathrm{CaCO}_{3}$ para o período chuvoso, sendo menores para este período (figura $2(\mathrm{j})$ ). De acordo com o teste ANOVA, existe evidência significativa para afirmar que a sazonalidade, a distribuição dos pontos de coleta e a interação dos dois fatores afetam no teor médio da dureza rejeitando as hipóteses nulas (Tabela 2). Geralmente ambientes com $\mathrm{pH}$ próximos à neutralidade apresentam uma dureza mole dado pelas baixas concentrações de carbonatos, sendo a reação com o $\mathrm{CO}_{2}$ para a produção de bicarbonato desprezível (Esteves,

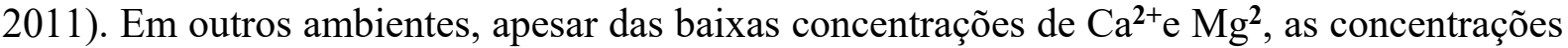
de $\mathrm{Na}_{2} \mathrm{CO}_{3}$ são consideráveis. Em outras palavras, estes ambientes com baixa dureza podem apresentar elevada alcalinidade. Os dados obtidos no presente estudo se mostraram correspondentes a águas moles de acordo com Mol e Alii (2005, apud Esteves (2011), que estabelece até $75 \mathrm{mg} \mathrm{L}^{-1}$ de $\mathrm{CaCO}_{3}$. De acordo com a legislação (Brasil, 2006) nos corpos d'água de reduzida dureza, a biota é mais sensível à presença de substâncias tóxicas, já que a toxicidade é inversamente proporcional ao grau de dureza da água, que tem efeito de reduzir a toxicidade de alguns metais como cobre, zinco, chumbo, etc. (USEPA, 2015). Os dados deste estudo apresentaram teores baixos de dureza se comparados com o estudo realizado por Paiva e Souza (2010) no rio Riachão em Caatiba- BA, que reportaram teores de 18,2 a 45,6 mg L $\mathrm{me}^{-1}$ de $\mathrm{CaCO}_{3}$.

De acordo com a UNEP (2008) a concentração média do cátion Ca em diferentes rios e lagos é de $13 \mathrm{mg} \mathrm{L}^{-1}$ na África, $22 \mathrm{mg} \mathrm{L}^{-1}$ nas Américas, $20 \mathrm{mg} \mathrm{L}^{-1}$ na Ásia, $45 \mathrm{mg} \mathrm{L}^{-1}$ na Europa e de $8 \mathrm{mg} \mathrm{L}^{-1}$ na Oceania. Nas águas naturais, o cálcio é o principal cátion, porém de acordo com Sioli (1956), em certas águas amazônicas pode ser muito escasso variando entre 1 a $4 \mathrm{mg} \mathrm{L}^{-1}$ de $\mathrm{Ca}$, valores baixos e dificilmente encontrados em outras regiões da Terra. Os valores médios obtidos para o período menos chuvoso estão entre 1,89 e $2,54 \mathrm{mg} \mathrm{L}^{-1}$ de Ca, e 
para o período chuvoso é de 0,57 a $0,81 \mathrm{mg} \mathrm{L}^{-1}$ de Ca. A composição iônica das águas varia em função das características do terreno, de áreas inundadas, presença da vegetação e uso dos solos ao longo do tempo (Tundisi e Matsumura Tundisi, 2008). Águas muito pouco mineralizadas com composição iônica dissolvida ocorrem em muitas regiões do Brasil. Na Figura 2 (k), pode ser observado que as menores concentrações de cálcio correspondem ao período chuvoso, o que concorda com Sioli (1956), que diz que o cálcio geralmente diminui com o aumento das chuvas. Estatisticamente, a sazonalidade e a localização dos pontos de amostragem influem significativamente nos teores médios do cálcio. Segundo Esteves (2011) e a UNEP (2008), o cálcio pode ter uma dinâmica sazonal e espacial relativamente marcada como resultado da atividade biológica. Em outro estudo, realizado por Kemerich et al. (2012) na caracterização química de água subterrânea numa área ocupada por cemitério em Santa Maria- RS reportaram teores de 4,65 a 17,85 $\mathrm{mg} \mathrm{L}^{-1}$ de Ca. Behera et al. (2014), ao estudarem o manguezal do rio Mahanadi na Índia, obtiveram valores elevados de teores de cálcio, de 125,4 a 400,8 $\mathrm{mg} \mathrm{L}^{-1}$, sendo atribuídos a efluentes de atividades industriais, comprovando, desta forma, sua dinâmica no meio ambiente.

\section{2. Índice de qualidade das águas (IQA)}

Com a aplicação da metodologia de cálculo de IQA para as amostragens consideradas neste estudo, foram determinados 40 diferentes resultados, que podem ser observados na Tabela 3.

Tabela 3. Resultados de IQA.

\begin{tabular}{lcccccccc}
\hline Período & Ponto & Long & Lat & $07 \mathrm{~h} 30$ & $10 \mathrm{~h} 30$ & $12 \mathrm{~h} 00$ & $13 \mathrm{~h} 30$ & $16 \mathrm{~h} 30$ \\
\hline \multirow{4}{*}{ PC } & P1 & 744945,8 & 9822509,3 & 56,576 & 90,998 & 57,649 & 56365 & 56,881 \\
& P2 & 747086,9 & 9826412,2 & 57,131 & 56,441 & 56,441 & 90,900 & 91,361 \\
& P3 & 748593,8 & 9829178,9 & 57,201 & 56,886 & 91,345 & 56,921 & 56,446 \\
& P4 & 754846,6 & 9835755,0 & 55,820 & 54,662 & 55,380 & 55,187 & 54,924 \\
\hline \multirow{4}{*}{ PMC } & P1 & 744945,8 & 9822509,3 & 85,575 & 75,593 & 89,932 & 88,535 & 83,385 \\
& P2 & 747086,9 & 9826412,2 & 86,818 & 55,042 & 86,837 & 91,329 & 88,277 \\
& P3 & 748593,8 & 9828178,9 & 79,305 & 88,954 & 88,871 & 91,394 & 88,724 \\
& P4 & 754846,6 & 9835755,0 & 92,013 & 89,671 & 86,734 & 91,550 & 91,676 \\
\hline
\end{tabular}

Interpretando tais resultados de acordo com o que recomenda a CETESB (2014), pode ser observado que durante o período chuvoso (PC), as águas estiveram, de modo geral, com qualidade inferior as águas do período menos chuvoso (PMC). Essa constatação pode ser facilmente observada na Tabela 4.

Tabela 4. Interpretações de IQA.

\begin{tabular}{ccccccccc}
\hline Período & Ponto & Long & Lat & 07h30 & $10 \mathrm{~h} 30$ & $12 \mathrm{~h} 00$ & $13 \mathrm{~h} 30$ & $16 \mathrm{~h} 30$ \\
\hline \multirow{4}{*}{ PC } & P1 & 744945,8 & 9822509,3 & Boa & Ótima & Boa & Boa & Boa \\
& P2 & 747086,9 & 9826412,2 & Boa & Boa & Boa & Ótima & Ótima \\
& P3 & 748593,8 & 9829178,9 & Boa & Boa & Boa & Boa & Boa \\
& P4 & 754846,6 & 9835755,0 & Boa & Boa & Boa & Boa & Boa \\
\hline \multirow{4}{*}{ PMC } & P1 & 744945,8 & 9822509,3 & Ótima & Boa & Ótima & Ótima & Ótima \\
& P2 & 747086,9 & 9826412,2 & Ótima & Boa & Ótima & Ótima & Ótima \\
& P3 & 748593,8 & 9828178,9 & Ótima & Ótima & Ótima & Ótima & Ótima \\
& P4 & 754846,6 & 9835755,0 & Ótima & Ótima & Ótima & Ótima & Ótima \\
\hline
\end{tabular}

Rev. Ambient. Água vol. 12 n. 3 Taubaté - May / Jun. 2017 
Tal diferença pode ser explicada pela sazonalidade, uma vez que maiores níveis pluviométricos implicam em maiores teores de poluentes, sendo carreados pela chuva do solo em direção ao rio - fenômeno chamado de wash off (Dotto, 2006). Tratando-se, então, de uma área que sofre intensa pressão antrópica - seja pelo lançamento direto de efluentes no solo, ou pela disposição inadequada de rejeitos domésticos e industriais. Admite-se que os menores valores de IQA durante a amostragem PC estão intrinsecamente ligados à maior quantidade de chuvas.

Dois parâmetros foram determinantes na redução dos valores de IQA para o PC: turbidez e coliformes. O parâmetro turbidez, apesar de indicativo de possível contaminação por patógenos, não representa sozinho indicativo de água de qualidade inferior. A turbidez é, no contexto amazônico, lugar comum nas caracterizações de águas brutas por conta do elevado teor de sedimentos que estas transportam (Filizola et al., 1999).

Estabelecendo uma conexão entre os valores de turbidez e as análises de coliformes termotolerantes, que indicaram altos teores de microrganismos, é possível afirmar que as altas taxas de turbidez podem estar relacionadas também, ao lançamento inadequado de efluentes frescos ou mais concentrados no rio (Von Sperling, 2005).

Esses dois parâmetros juntos podem indicar contaminação de águas por patógenos uma vez que: 1) as partículas em suspensão que contribuem para o aumento da turbidez podem servir como meio para a proliferação de bactérias (Von Sperling, 2005); 2) a presença de microrganismos que só se desenvolvem no intestino de animais quentes indica a presença de carga orgânica proveniente de efluentes domésticos (CB6).

Além de efluentes das atividades nativas do município de Barcarena-PA, a zona portuária alvo de estudo pode estar recebendo efluentes provenientes dos navios que ali transitam diariamente. Além de efluentes domésticos, estes navios podem estar despejando águas de lastro de outros ecossistemas, alterando não só as características físico-químicas da água, mas também sua composição de fauna e flora nas escalas macro e micro (Serafin e Henkes, 2013).

A inferioridade dos valores de IQA de PC em relação a PMC não implica, no entanto, em águas de qualidade insatisfatória. Rios de dimensões como o Rio Pará e que sofrem influência direta de maré oceânica, tem grande capacidade de diluição de seus poluentes. Damasceno et al. (2015), ao estudarem um ciclo sazonal de um trecho do rio Amazonas, no município de Macapá, obtiveram IQA com classificações de boa e ótima. Em outro estudo realizado por Alves et al. (2012) no rio Arari no Marajó- PA, foi obtido uma classificação de IQA entre ruim e regular, e estes mesmos resultados foram obtidos por Lobato et al. (2015) em um estudo realizado no lago Tucuruí- PA.

\section{CONCLUSÃO}

Dos parâmetros analisados, com exceção do $\mathrm{pH}$, estatisticamente o fator localização dos pontos de amostragem tem uma influência significativa nos valores médios da temperatura, condutividade, cor, sólidos totais dissolvidos, cloreto, sódio, potássio, alcalinidade, dureza e cálcio com um nível de significância de 5\%. Tais interferências se devem a hidrodinâmica do corpo hídrico pela interferência da entrada e saída de correntes oceânicas, produto da maré, e por outro lado a recepção de efluentes domésticos e industriais.

A condutividade, STD e sódio foram os parâmetros que apresentaram uma maior concentração no ponto P-02 que recebe a maior influência das atividades das empresas localizadas no pólo industrial de Barcarena-PA, parâmetros estes relacionados com lançamento de efluentes industriais e esgoto doméstico.

Segundo o teste ANOVA, a sazonalidade tem influência significativa nos teores médios dos parâmetros de $\mathrm{pH}$, temperatura, condutividade, $\mathrm{STD}$, cor, sódio, potássio, dureza e cálcio. 
Porém, não tem influência no cloreto e alcalinidade, pois com o aumento das chuvas alguns parâmetros da qualidade das águas podem ser afetados.

A interação da sazonalidade e localização dos pontos de amostragem têm influência significativa no $\mathrm{pH}$, condutividade, $\mathrm{STD}$, cor, sódio, potássio, dureza e alcalinidade, mas não têm influência no cálcio, cloreto e temperatura.

Os parâmetros analisados neste estudo mostraram valores dentro do padrão de qualidade da resolução CONAMA 357/2005, com exceção da cor no ponto P0-4 no período chuvoso.

Os Índices de Qualidade da água se mostraram satisfatórios, com aproximadamente metade das amostras caracterizadas com índice bom, e as demais caracterizadas com IQA ótima. Estes índices refletem a capacidade de diluição de poluentes que um rio do porte do Rio Pará tem, este fenômeno potencializado pelo efeito de marés oceânicas no corpo hídrico estudado.

Apesar dos índices satisfatórios retratados pelo IQA, as amostras apresentaram considerável presença de coliformes termotolerantes.

\section{AGRADECIMENTOS}

Ao Programa de Pós-Graduação em Ciências Ambientais (PPGCA) da Universidade do Estado do Pará (UEPA). À Coordenação de Aperfeiçoamento de Pessoal de Nível Superior (CAPES), pela bolsa de estudo. Ao projeto Qualidade dos Recursos Hídricos para o consumo humano na área de abrangência do Polo Industrial de Barcarena Pará da FAPESPA, edital $013 / 2009$, pelo financiamento para as coletas e análises.

\section{REFERÊNCIAS}

ASSOCIAÇÃO BRASILEIRA DE NORMAS TÉCNICAS. NRB 9898 - Preservação e técnicas de amostragem de efluentes líquidos e corpos receptores. Rio de Janeiro, 1987.

ALFARO, J. D. B. Determinación de cationes en agua potable del cantón de Grecia, Costa Rica por absorción atómica. Revista. InterSedes, v 15, p. 95-106, 2014. http://repositoriodigital.academica.mx/jspui/handle/987654321/402610

ALVARENGA, L. A. et al. Estudo da qualidade e quantidade da água em microbacia, afluente do rio Paraíba do Sul - São Paulo, após ações de preservação ambiental. Revista Ambiente \& Água, v. 7, n. 3, p. 228-240, 2012. http://dx.doi.org/10.4136/ambi-agua.987

ALVES, I. C. C.; El-ROBRINI, M.; SANTOS, M. de L. S. MONTEIRO S. M.; BARBOSA, L. P. F.; GUIMARÃES, J. T. F. Qualidade das águas superficiais e avaliação do estado trófico do Rio Arari (Ilha de Marajó, norte do Brasil). Acta Amazonica, v. 42, n. 1, p. 115-124, 2012. http://dx.doi.org/10.1590/S0044-59672012000100014

ARAUJO, M. C. de; OLIVEIRA, M. B M. de. Monitoramento da qualidade das águas de um riacho da Universidade Federal de Pernambuco, Brasil. Revista Ambiente \& Água, v. 8, n. 3, p. 247-257, 2013. http://dx.doi.org/10.4136/ambi-agua.1192

AMERICAN PUBLIC HEALTH ASSOCIATION et al. Standard methods for the examination of water and wastewater. $19^{\text {th }}$ ed. Washington, 1995. $1134 \mathrm{p}$. 
BARRETO, L. V.; FRAGA, M. S.; BARROS, F. M.; ROCHA, F. A.; AMORIM, J. S.; DE CARVALHO, S. R. et al. Relação entre vazão e qualidade da água em uma seção de rio. Revista Ambiente \& Água, v. 9, p. 118-129, 2014. http://dx.doi.org/10.4136/ambiagua. 1278

BEHERA B. C.; MISHRA R. R.; PATRA J. K.; DUTTA S. K.; THATOI, H. N. Physico chemical properties of water sample collected from Mangrove Ecosystem of Mahanadi river delta, Odisha, India. American Journal of Marine Science, v. 2, n. 1, p. 19-24, 2014. http://dx.doi.org/10.12691/marine-2-1-3

BOESCH, D. F. Challenges and opportunities for science in reducing nutrient over-enrichment of coastal ecosystems. Estuaries, v. 25, n. 4b, p. 886-900, 2002. http://dx.doi.org/10.1007/BF02804914

BRASIL. Secretaria de Vigilância em Saúde. Vigilância e controle da qualidade da água para o consumo. Brasília, 2006. 212 p.

BUCCI, M. H. S.; OLIVEIRA, L. F. C. Índices de qualidade da água e de estado trófico na represa Dr. João Penido (Juiz de Fora, MG). Revista Ambiente \& Água, v. 9, n. 1, p. 130-148, 2014. http://dx.doi.org/10.4136/ambi-agua.1290

BUCCI, M. M. H. S.; DELGADO, F. E. F. da; SANTOS, D. da S.; OLIVEIRA, L. F C.de. Análise de metais, agrotóxicos, parâmetros físico-químicos e microbiológicos nas águas da Represa Dr. João Penido, Juiz de Fora, MG. Revista Ambiente \& Água, v. 10, n. 4, p. 804-824, 2015. http://dx.doi.org/10.4136/ambi-agua.1534

CARREÓN, E. T.; SEDENO J. E. D.; LOPEZ E. L. Evaluación de la calidad del agua en la Laguna de Yuriria, Guanajuato, México, mediante técnicas multivariadas: un análisis de valoración para dos épocas 2005, 2009-2010. Revista Internacional Contaminación Ambiental, v. 29, n. 3, p. 147-163, 2013.

COMPANHIA AMBIENTAL DO ESTADO DE SÃO PAULO. IQA: Índice de qualidade das águas. Disponível em: http://www.cetesb.sp.gov.br/agua/ÁguasSuperficiais/42-Índicede-Qualidade-dasÁguas-(iqa). Acesso em: 28 set. 2014.

COMPANHIA AMBIENTAL DO ESTADO DE SÃO PAULO. Website. 2012. http://www.cetesb.sp.gov.br. Acesso: 20 set. 2012.

CHAN SANTISTEBAN, M. L.; PENA, W. Evaluación de la calidad del agua superficial con potencial para consumo humano en la cuenca alta del SisIcán, Guatemala. Cuadernos de Investigación UNED, v. 7, n. 1, p. 19-23, 2015.

COHEN, J. C. P.; BELTRAO, J. da C.; GANDU, A. W.; SILVA, R. R. da. Influência do desmatamento sobre o ciclo hidrológico na Amazônia. Ciência e Cultura, v. 59, n. 3, p. 36-39, 2007.

COMPANHIA DOCAS DO PARÁ - CDP. Atualização do plano de desenvolvimento e zoneamento do porto de Vila do Conde. Belém, 2010.

CONSELHO NACIONAL DO MEIO AMBIENTE. Resolução No 430, de 13 de Maio de 2011. Dispõe sobre as condições e padrões de lançamento de efluentes, complementa e altera a Resolução no 357, de 17 de março de 2005, do Conselho Nacional do Meio AmbienteCONAMA. Diário Oficial [da] União, n. 92, 16 maio 2011, p. 89. Brasilia, 2011. 
CONSELHO NACIONAL DO MEIO AMBIENTE. Resolução n 357, de 17 de março de 2005. Dispõe sobre a classificação dos corpos de água e diretrizes ambientais para o seu enquadramento, bem como estabelece as condições e padrões de lançamento de efluentes, e dá outras providências. Diário Oficial [da] União, n. 53, 18 mar. 2005, p. 58-63.

DAMASCENO, M. da C. S.; RIBEIRO, H. M. C.; TAKIYAMA, L. R.; PAULA, M. T. de. Avaliação sazonal da qualidade das águas superficiais do Rio Amazonas na orla da cidade de Macapá, Amapá, Brasil. Revista Ambiente \& Água, v. 10, n. 3, p. 598-613, 2015. http://dx.doi.org/10.4136/ambi-agua.1606

DOTTO, C. B. S.; PAIVA, E. M. C. D.; SILVA, L. F. Acumulação e balanço de sedimentos em superfícies asfálticas em área urbana de Santa Maria - RS. Revista Brasileira de Recursos Hidrícos, v. 12, p. 1-11, 2006.

DREVER, J. I. The Geochemistry of natural waters. [S.1.]: Prentice Hall, 1988.

EMPRESA BRASILEIRA DE PESQUISA AGROPECUÁRIA. Centro Nacional de Pesquisa de Solos. Sistema brasileiro de classificação de solos. Brasília, 2013. 306p.

ESTEVES, F. Fundamentos de limnologia, Rio de Janeiro: Interciência, 1998. 601 p.

ESTEVES, F. Fundamentos de limnologia. 3. ed. Rio de Janeiro: Interciência, 2011. 826 p.

FILIZOLA, N.; GUYOT, J. L.; BOAVENTURA, G. Fluxo de sedimentos em suspensão na Amazônia-uma análise a partir da base de dados da ANEEL. 1999. Disponível em: http://www.ana.gov.br/hibam/publicacoes/filizola_1.pdf.

FITTKAU, E. J.; JUNK, W.; KLINGE, H.; SIOLI, H. Substrate and vegetation in the Amazon region. In: CRAMER, J. (Ed.). Beriohto dor internationalen Symposien der Internationalen Vereinigung für Vegetationskunde. [S.1.: s.n.]: 1975. p. 73-93.

FOOD AND AGRICULTURE ORGANIZATION OF THE UNITED NATIONS. The outlook for 2050 is encouraging, globally, but much work is needed to achieve sustainable water use and ensure food security for all. Rome, 2015. p. 76

FONSECA, H. S.; SALVADOR, N. N. B. Estudo integrado da qualidade das águas da bacia hidrográfica do Rio Bonito em Descalvado - SP. Revista do Instituto Adolfo Lutz, v. 64, n. 2, 2005.

FRANČIŠKOVIĆ-BILINSKI S.; CUCULIĆ V.; BILINSKI H.; HÄUSLER H.; STADLER $\mathrm{Ph}$. Geochemical and stable isotopic variability within two rivers rising under the same mountain, but belonging to two distant watersheds. Chemie der Erde-Geochemistry, v. 73, p. 293-308, 2013.

GOHER, M. E.; HASSAN, A. M.; ABDEL-MONIEM, I. A.; FAHMY, A.H. El-SAYED, S. M. Evaluation of surface water quality and heavy metal indices of Ismailia Canal, Nile River, Egypt. The Egyptian Journal of Aquatic Research, v. 40, p. 225-233, 2014. http://dx.doi.org/10.1016/j.ejar.2014.09.001

HEM, J. D. Study and Interpretation of the chemical characteristics of natural waters. Washington: U.S. Geological Survey, 1970. 363p.

INSTITUTO NACIONAL DE METEOROLOGIA. Website. 2012. Disponível em: www.inmet.gov.br. Acesso em: 2012. 
KEMERICH, P. D. C.; BORBA, W. F.; SILVA, R. F.; BARROS, G.; GERHARDT, A. E.; FLORES, C. E. B. Valores anômalos de metais pesados em solo de cemitério. Revista Ambiente \& Água, v. 7 n. 1, p. 140-156, 2012. http://dx.doi.org/10.4136/ambi-agua.838

LAPPONI, J. C. Estatística usando Excel. 4. ed. Rio de Janeiro: ELSEVIER- CAMPUS, 2005. p. 476.

LEÓN, J. A. C. Calidad de aguas para estudiantes de ciencias ambientales. Bogotá: Universidad Distrital Francisco José de Caldas, 2005.

LOBATO, T. C.; HAUSER-DAVIS, R. A.; OLIVEIRA, T. F.; SILVEIRA, A. M.; SILVA, H. A. N.; TAVARES, M. R. M. et al. Construction of a novel water quality index and quality indicator for reservoir water quality evaluation: a case study in the Amazon region. Journal of Hydrology, v. 522, p. 674-683, 2015. http://dx.doi.org/10.1016/j.jhydrol.2015.01.021

LUCAS, A. A. T.; MOURA, A. S. A; NETTO, A de O. A; FACCIOL, G. G; SOUSA, I. F. Qualidade da água no riacho Jacaré, Sergipe e Brasil usada para irrigação. Revista Brasileira de Agricultura Irrigada, v. 8, n. 2, p. 98-105, 2014. http://dx.doi.org/10.7127/RBAI.V8N200228

MADDEN, N.; LEWIS, A.; DAVIS, M. Thermal effluent from the power sector: an analysis of once-through cooling system impacts on surface water temperature. Environmental Research Letters, v. 8, 2013.

MALHEIROS, C. H.; HARDOIM, E. L.; DE LIMA, Z. M.; AMORIM, R. S. S. Qualidade da água de uma represa localizada em área agrícola (Campo Verde, MT, Brasil). Revista Ambiente \& Água, v. 7, n. 2, p. 245-262, 2012. http://dx.doi.org/10.4136/ambiagua.904

MARIMUTHU, T.; RAJENDRAN, S.; MANIVANNAN, M.. An analysis of efficiency and water quality parameters of dye effluent treatment plant, Karur, Tamilnadu, India. Journal of Environmental Science, Computer Science and Engineering \& Technology, v. 2, n. 3, p. 567-571, 2013.

MARMONTEL, C. V. F.; RODRIGUES, V. A. Parâmetros Indicativos para qualidade da água em nascentes com diferentes coberturas de terra e conservação da vegetação ciliar. Floresta e Ambiente, v. 22, n. 2, p. 171-181, 2015. http://dx.doi.org/10.1590/21798087.082014

MATIC, N.; MIKLAVCIC, I.; MALDINI, K.; DAMIR, T.; CUCULIC, V.; CARDELLINI, C. ET AL. Geochemical and isotopic characteristics of karstic springs in coastal mountains (Southern Croatia). Journal of Geochemical Exploration, n. 132, p. 90-110, 2013. http://dx.doi.org/10.1016/j.gexplo.2013.06.007

MIRANDA, R. G.; PEREIRA, S. de F. P.; ALVES, D. T. V.; OLIVEIRA, G. R. F. Qualidade dos recursos hídricos da Amazônia - Rio Tapajós: avaliação de caso em relação aos elementos químicos e parâmetros físico-químicos. Revista Água \& Ambiente, v. 4, n. 2, 2009. http://dx.doi.org/10.4136/ambi-agua.88 
MONACO, P. A.; MATOS, A. T.; SILVA, N. C. L.; LIMA, C. R. da.; MOREIRA, R. M. Estimativa da concentração de potássio a partir da condutividade elétrica em água residuarias da lavagem e despolpa dos frutos do cafeeiro. Universidade Federal de Viçosa. 2011. Disponível em:

http://www.poscolheita.com.br/poscolheita/Artigos/Meio\%20Ambiente/CONIRD\%20P AOLA\%2011.pdf. Acesso: 8 set. 2012.

OLIVEIRA, B. S. S.de; CUNHA, A. C. da. Correlação entre qualidade da água e variabilidade da precipitação no sul do Estado do Amapá. Revista Ambiente \& Âgua, v. 9, n. 2, p. 261-275, 2014. http://dx.doi.org/10.4136/ambi-agua.1287

PAIVA, L. C.; SOUZA, A. O. Avaliação de alguns parâmetros físico-químicos da água do rio Riachão no município de Caatiba - BA. Enciclopédia Biosfera, v. 6, n. 9, 2010.

PAZ, A. C.; FREDOU, F L.; FREDOU, T. Caracterização da atividade pesqueira em Vila do Conde (Barcarena, Pará), no estuário amazônico. Boletim do Museu Paraense Emílio Goeldi. Ciências humanas, v. 6, n. 2, 2011. http://repositorio.ufpa.br/jspui/handle/2011/3849

PEREIRA, S de F.; LIMA, M. A.; FREITAS, K. H.; MESCOUTO, C. S.; SARAIVA, A. F. Estudo químico ambiental do Rio Murucupi- Barcarena, PA, Brasil área impactada pela produção de alumínio. Revista Água \& Ambiente, v. 2, n. 3, 2007. http://dx.doi.org/10.4136/ambi-agua.34

PONTES, P. P; MARQUES, A. R; MARQUES, G. F. Efeito do uso e ocupação do solo na qualidade da água na micro-bacia do Córrego Banguelo - Contagem. Revista Água \& Ambiente, v. 7, n. 3, p. 183-194, 2012. http://dx.doi.org/10.4136/ambi-agua.962

PIÑEIRO DI BLASI, J. I.; MARTÍNEZ TORRES, J.; GARCÍA NIETO, P. J.; ALONSO FERNÁNDEZ, J. R.; DÍAZ MUÑIZ, C.; TABOADA, J. Analysis and detection of outliers in water quality parameters from 'different automated monitoring stations in the Miño river basin (NW Spain). Ecological Engineering, v. 60, p. 60-66, 2013. http://dx.doi.org/10.1016/j.ecoleng.2013.07.054

RIBEIRO, E. A.; SANDRI, E. A.; BOÊNO, J. A. Qualidade da água de córrego em função do lançamento de efluente de abate de bovino. Revista Brasileira de Engenharia Agrícola e Ambiental, v. 17, n. 4, p. 245-433, 2013. http://dx.doi.org/10.1590/S141543662013000400011

RODIER, J. Analisis de las aguas. Barcelona: OMEGA, 1981. p. 1059.

SÁ FILHO, J. A. R. de. Avaliação qualitativa das águas no sistema da macrodrenagem da Bacia do Tabuleiro do Martins - Maceió/ AL. 2010. Dissertação (Mestrado em Recursos Hídricos e Saneamento) - Universidade Federal de Alagoas, Maceió, 2010.

SANCHEZ, L. E. Avaliação de impacto ambiental: conceitos e métodos. São Paulo: Oficina de Textos, 2006. p. 24.

SANTI, G. M.; FURTADO, C. M.; MENEZES, R. S. A.; KEPPELER, E. C. Variabilidade espacial de parâmetros e indicadores de qualidade da água na sub-bacia hidrográfica do igarapé São Francisco, Rio Branco, Acre, Brasil. Ecologia Aplicada, v. 11, n.1, p. 23-31, 2012. http://dx.doi.org/10.21704/rea.v11i1-2.422 
SANTOS, A. G. da S. dos; MORAES, L. R. S.; NASCIMENTO, S. A. de M. Qualidade da água subterrânea e necrochorumeno entorno do cemitério do Campo Santo em SalvadorBA. Revista Eletrônica GESTA, v. 3, n. 1, p. 39-60, 2015. http://dx.doi.org/10.17565/gesta.v3i1.12456

SILVA, A. E. P.; ANGELIS, C. F.; MACHADO, L. A. T.; WAICHAMAN, A.V. Influência da precipitação na qualidade da água do Rio Purus. Acta Amazonica, v. 38, n. 4, p. 733 742. 2008. http://dx.doi.org/10.1590/S0044-59672008000400017

SIOLI, H. O Rio Arapiuns: estudo limnológico de um corpo d'água da região do terciário, plioceno, série das barreiras, do Baixo Amazonas. Boletim Técnico IAN, p. 3-115, 1956.

SIOLI, H. Pesquisas limnológicas na região da estrada de ferro de Bragança- Estado do Pará- Brasil. Belém: IAN, 1960.

SIOLI, H. Valores de pH de águas amazônicas. Boletim Museo Paraense Emílio Goldie. Geologia, v. 1, p. 1-35, 1957.

SIQUEIRA, G. W.; APRILE, F.; MIGUEIS, A. M. Diagnóstico da qualidade da água do rio Parauapebas (Pará - Brasil). Acta Amazonica, v. 42, n. 3, p. 413-422, 2012. http://dx.doi.org/10.1590/S0044-59672012000300014

SKORONSKI, E. et al. Estudo da aplicação de tanino no tratamento de água para abastecimento captada no rio Tubarão, na cidade de Tubarão, SC. Revista Ambiente \& Água, v. 9, n. 4, p. 679-687, 2014. http://dx.doi.org/10.4136/ambi-agua.1303

SOARES, G. T.; TÁVORA, F.; NUNES. R de O. Índice de qualidade das águas claras, Alvorada do Oeste RO. 2009. TCC (Graduação em Ciências Biomédicas) - Faculdade de Ciências Biomédicas, Cacoal, 2009.

SERAFIN, I. T.; HENKES, J. A. Água de lastro: um problema ambiental. Revista Gestão \& Sustentabilidade Ambiental, v. 2, n. 1, p. 92-112, 2013.

SIOLI, H. Amazônia: fundamentos de ecologia da maior região de florestas tropicais. Petrópolis: Vozes, 1984. 72 p.

SOUZA, J. A. R. de.; MOREIRA, D. A.; CONDÉ, N. M.; CARVALHO, W. B de.; CARVALHO, C. V. M. Análise das condições de potabilidade das águas de surgências em Ubá, MG. Revista Ambiente \& Água, v. 10, n. 3, p. 614-622, 2015. http://dx.doi.org/10.4136/ambi-agua.1630

TUNDISI, J. G.; MATSUMURA TUNDISI, T. Limnologia. São Paulo: Oficina de Textos, 2008. $632 \mathrm{p}$.

UNITED STATES. Environmental Protection Agency - USEPA. Secondary maximum contaminant levels: a strategy for drinking water quality and consumer acceptability. 2015. Disponível em: http://www.waterrf.org/PublicReportLibrary/4537.pdf. Acesso em: set.

UNITED NATIONS ENVIRONMENT PROGRAMME - UNEP. Vital water graphics: an overview of the state of the World's Fresh and marine waters. 2nd Edition. Nairobi, 2008.

VAN NIEKERK, H.; SILBERBAUER, M. J.; MALULEKE, M. Geographical differences in the relationship between total dissolved solids and electrical conductivity in South African rivers. Water SA, v. 40, n. 1, p. 133-137, 2014. 
VASCONCELOS, V. de M. M.; SOUZA, C. F. Caracterização dos parâmetros de qualidade da água do manancial Utinga, Belém, PA, Brasil. Revista Ambiente \& Água, v. 6, n. 2, 2011. http://dx.doi.org/10.4136/ambi-agua.202

VON SPERLING, M. Estudos de modelagem da qualidade da água de rios. Belo Horizonte: UFMG, 2007. Vol. 7. 452 p.

VON SPERLING, M. Introdução à qualidade das águas e ao tratamento de esgoto. 3. ed. Belo Horizonte: UFMG, 2005. 588 p.

ZHANG, Z.; TAO, F.; DU, J.; SHI, P.; YU, D.; MENG, Y. et al. Surface water quality and its control in a river with intensive human impacts - a case study of the Xiangjiang River, China. Journal of Environmental Management, v. 91, p. 2483-2490, 2010. http://dx.doi.org/10.1016/j.jenvman.2010.07.002

ZUIN, V. G.; IORIATTI, M. C. S.; MATHEUS C. E. O emprego de parâmetros físicos e químicos para a avaliação da qualidade de águas naturais: uma proposta para a educação química e ambiental na perspectiva CTSA. Química Nova na Escola, v. 31. 2009. 


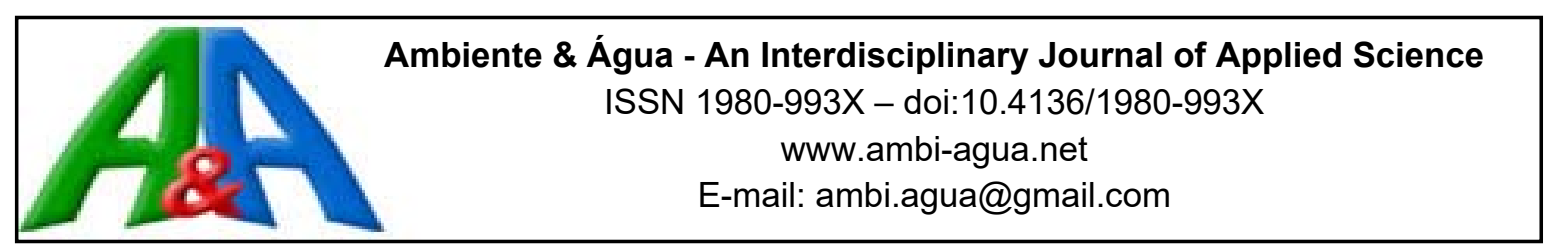

\title{
Estudo da tratabilidade de lixiviado gerado em um aterro controlado
}

\author{
doi:10.4136/ambi-agua.1957 \\ Received: 15 jun. 2016; Accepted: 18 Feb. 2017

\section{Daniela Vidal Vasconcelos; Larissa Loureiro Salgueiro Silva; Igor Lopes Guerra; Juacyara Carbonelli Campos*}

\author{
Universidade Federal do Rio de Janeiro (UFRJ), Escola de Química, \\ Rio de Janeiro, RJ, Brasil \\ Departamento de Processos Inorgânicos \\ *Autor correspondente: e-mail: juacyara@eq.ufrj.br, \\ dvvasconcelos@poli.ufrj.br, larissaloureiross@hotmail.com, \\ ilopesguerra@gmail.com
}

\section{RESUMO}

O presente trabalho avaliou os processos de coagulação/floculação, adsorção em carvão ativado em pó (CAP) e reação com Fenton para redução da concentração dos poluentes e aumento da biodegradabilidade do lixiviado. No processo de coagulação/floculação foram avaliados o pH (4 a 8) e a concentração de cloreto férrico (100 a $\left.600 \mathrm{mg} \mathrm{L}^{-1}\right)$. No processo de adsorção em CAP, foram avaliadas as concentrações de $0,1-5,0 \mathrm{~g} \mathrm{~L}^{-1}$ de CAP, e na reação com Fenton, foram avaliadas as relações DQO: $\mathrm{H}_{2} \mathrm{O}_{2}$ [1:0,5, 1:1, 1:2 e 1:5], além das relações $\mathrm{Fe}: \mathrm{H}_{2} \mathrm{O}_{2}$ [1:3, 1:5 e 1:10]. Nas melhores condições obtidas, foi avaliada a biodegradabilidade aeróbia dos efluentes tratados pelo método de Zahn-Wellens. O resultado do processo de coagulação/floculação foi de $22,9 \%$ de remoção da DQO e $64 \%$ de COT, utilizando 300 mg L' ${ }^{1}$ de coagulante em pH 4. Na adsorção em CAP, foram obtidas remoções de 69\% da DQO, utilizando $5 \mathrm{~g} \mathrm{~L}^{-1}$ de carvão. Na reação de Fenton, foram alcançadas remoções de $82,3 \%$ de DQO (para DQO: $\mathrm{H}_{2} \mathrm{O}_{2}=1: 2$ e $\mathrm{Fe}: \mathrm{H}_{2} \mathrm{O}_{2}=1: 3$ ). Os resultados de biodegradabilidade aeróbia mostraram que apenas o lixiviado tratado com Fenton apresentou uma biodegradabilidade de 12 pontos percentuais maior em relação ao bruto, mostrando a sua potencialidade como pré-tratamento ao processo biológico.

Palavras-chave: biodegradabilidade aeróbia, carvão ativado, coagulação/floculação, Reativo de Fenton.

\section{Treatability study of leachate generated in a controlled landfill}

\begin{abstract}
This study evaluated the processes of coagulation/flocculation, activated carbon adsorption and reaction with Fenton to reduce the concentration of pollutants and increase aerobic biodegradation of leachate so that it can be treated by biological process. For the process of coagulation / flocculation, $\mathrm{pH}$ (4 to 8) and the concentration of ferric chloride (100 to $600 \mathrm{mg} \mathrm{L}^{-1}$ ) were evaluated. For the adsorption on activated carbon (PAC) process, CAP concentrations of 0.1 and $5.0 \mathrm{~g} \mathrm{~L}^{-1}$ were evaluated; and for Fenton reaction, $\mathrm{COD}: \mathrm{H}_{2} \mathrm{O}_{2}$ ratio[1: 0.5, 1: 1, 1: 2 and 1: 5] and $\mathrm{Fe}: \mathrm{H}_{2} \mathrm{O}_{2}$ [1:3, 1: 5 and 1:10] were evaluated. The aerobic biodegradation of treated leachate by Zahn-Wellens method was evaluated under the best-
\end{abstract}


obtained conditions. The results for coagulation/flocculation was $22.9 \%$ removal of COD and $64 \%$ of TOC, using $300 \mathrm{mg} \mathrm{L}^{-1}$ of coagulant and $\mathrm{pH}$ equal to 4 . For the adsorption on activated carbon, removal of $69 \%$ of COD was reached using $5 \mathrm{~g} \mathrm{~L}^{-1} \mathrm{PAC}$. For Fenton reaction, removal of $82.3 \%$ for COD was reached (for COD: $\mathrm{H}_{2} \mathrm{O}_{2}=1: 2, \mathrm{Fe}: \mathrm{H}_{2} \mathrm{O}_{2}=1: 3$ ). The results of aerobic biodegradability showed that only Fenton-treated leachate could increase biodegradability by 12 percentage points compared with raw leachate. The results showed the potential of the Fenton process as a pre-treatment to the biological process.

Keywords: activated carbon, aerobic biodegradability, coagulation/flocculation, Fenton reaction.

\section{INTRODUÇÃO}

O lixiviado de aterro sanitário pode ser definido como uma mistura de líquidos proveniente da umidade natural que ocorre dentro e fora da pilha de resíduos, da água presente nos materiais depositados, da atividade microbiana e da água de infiltração, acrescentando-se os materiais dissolvidos ou suspensos que foram carreados no processo de lixiviação (Sá et al., 2012).

O uso de processos biológicos para o tratamento de lixiviado é recorrente, sendo o sistema de lodos ativados o mais aplicado devido ao amplo conhecimento das condições e à facilidade de operação. No entanto, conforme o tempo de operação do aterro, há um aumento do teor de matéria orgânica recalcitrante do lixiviado, havendo necessidade de pré-tratamento por processos físico-químicos (Cheibub et al., 2014).

Alguns estudos feitos nos últimos cinco anos pelos pesquisadores Ferreira e Campos (2014), Gewehr (2012), Cheibub et al. (2014) e Li et al. (2010) utilizaram o processo de coagulação/floculação com coagulante cloreto férrico para o tratamento de lixiviados dos seguintes aterros, respectivamente: Gericinó/RJ, Porto Alegre/RS, Gramacho/RJ e Shuangkou Town/China. Esse coagulante é o mais observado na literatura no tratamento de lixiviados devido à forte interação com as substâncias húmicas presentes no efluente (Cheibub et al., 2014).

Ferreira e Campos (2014) utilizaram $500 \mathrm{mgFe}^{+3} \mathrm{~L}^{-1} \mathrm{em}$ um lixiviado com $1.981 \mathrm{mg} \mathrm{L}^{-1}$ de DQO (Demanda Química de Oxigênio) e obtiveram 60\% de eficiência de remoção. Com uma concentração aproximadamente duas vezes maior de $\mathrm{Fe}^{3+}$ (1.102 $\left.\mathrm{mg} \mathrm{L}^{-1}\right)$, Gewehr (2012) atingiu o mesmo nível de eficiência (63\%) para um lixiviado que apresentava DQO de 4.798 $\mathrm{mg} \mathrm{L}^{-1}$. Nesse sentido, a natureza do lixiviado (tipo de resíduo, operação do aterro, clima entre outras variáveis) são definitivas para a eficiência de tal processo (Cheibub et al., 2014).

O carvão ativado (CA) é um adsorvente bastante utilizado em tratamentos de efluentes, pois apresenta características capazes de remover parte do material orgânico dissolvido remanescente de outros tratamentos (Metcalf \& Eddy, 2003). Estudos realizados por Maia (2012) e Cotman e Gotvajn (2010), utilizando adsorção em carvão ativado em pó (CAP) como pré-tratamento do lixiviado do Aterro Metropolitano de Gramacho (RJ) e de um aterro na Eslovênia, respectivamente, mostraram que podem ser alcançadas eficiências de remoção de DQO de $80 \%$ e $86 \%$, quando utilizadas dosagens de 10 e $50 \mathrm{~g} \mathrm{~L}^{-1}$ de CAP, respectivamente.

Os Processos Oxidativos Avançados (POAs) têm como objetivo principal a formação de oxidantes fortes, como é o caso da radical hidroxila, $\mathrm{OH}^{\bullet}\left(\mathrm{EH}^{0}=2,8 \mathrm{~V}\right)$, o qual irá oxidar a matéria orgânica em compostos mais simples. Existem diversos tipos de POA, contudo, é constante a utilização da reação de Fenton para o tratamento de lixiviados, pois neste caso podem ocorrer dois fenômenos: a oxidação e a adsorção da matéria orgânica no lodo formado (Deng e Egnlehardt, 2006). Assim, na reação de Fenton o peróxido de hidrogênio é adicionado ao efluente em presença de um sal de ferro, gerando $\mathrm{OH}^{\bullet}$ (Fenton, 1894). Essa técnica é capaz de 
tornar os compostos mais sensíveis ao tratamento biológico subsequente ou reduzir a sua toxicidade (Metcalf \& Eddy, 2003).

Estudos nacionais e internacionais realizados por Queiroz et al. (2011), Moravia et al. (2011), Cotman e Gotvajn (2010) e Zhang et al. (2012) que utilizaram a reação de Fenton como técnica de tratamento do lixiviado de Gericinó/RJ, CTR Belo Horizonte/MG, Aterro Municipal da Eslovênia e Wuhan na China, respectivamente, obtiveram eficiências maiores que $60 \%$ na remoção da DQO.

O presente trabalho visa avaliar técnicas de tratamento para um lixiviado gerado em um aterro controlado situado no Estado do Rio de Janeiro, de forma a minimizar o impacto ocasionado pela elevada concentração de matéria orgânica e, dessa forma, aumentar a sua biodegradabilidade para que possa ser tratado em sistemas biológicos. Esse aterro operou por 22 anos e na época do estudo, já estava encerrado (desde 2012). A recirculação do lixiviado era realizada sob o maciço de resíduos enterrados, através de caminhões com aspersores acoplados na traseira, que coletavam o lixiviado no tanque de recepção.

\section{MATERIAS E MÉTODOS}

As tecnologias utilizadas como tratamento do lixiviado do aterro controlado avaliadas nesse trabalho foram: Coagulação/Floculação, utilizando como coagulante o cloreto férrico $\left(\mathrm{FeCl}_{3}\right)$, adsorção com carvão ativado em pó (CAP) e Reação de Fenton, e após todos os tratamentos foram executados testes de biodegradabilidade aeróbia em cada um dos efluentes. O fluxograma da Figura 1 demonstra as sequências de tratamento estudadas.

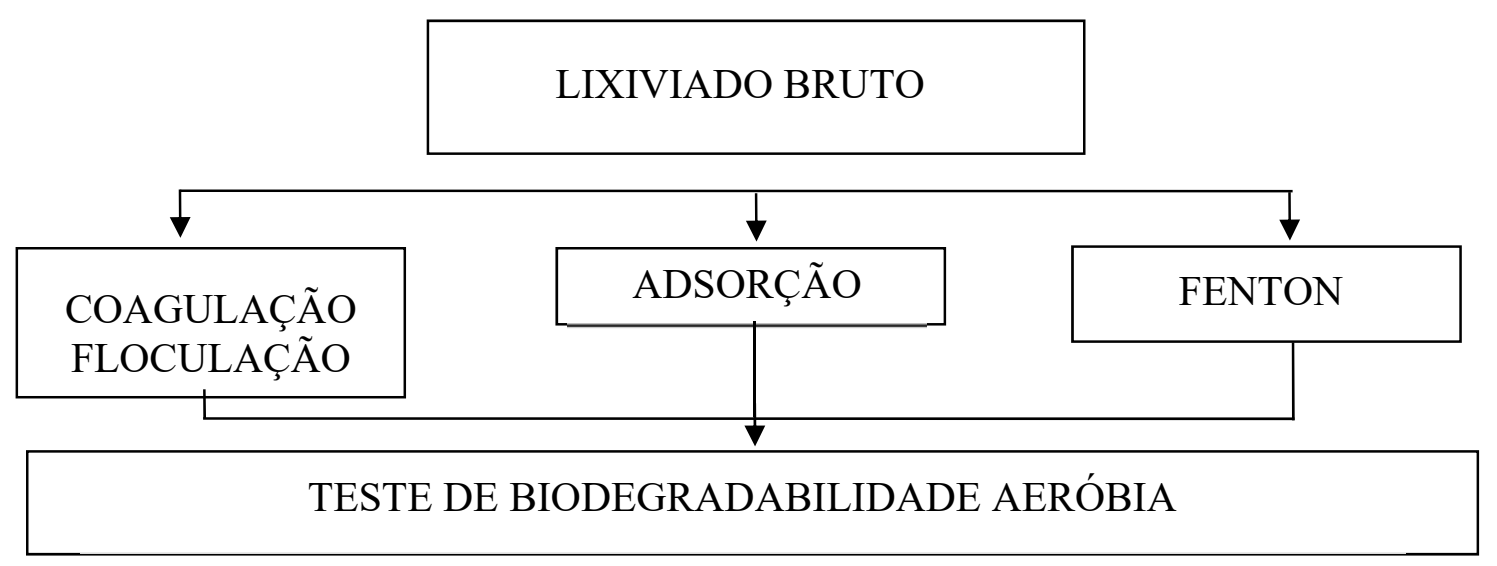

Figura 1. Metodologia de tratamento do lixiviado.

\subsection{Coleta do efluente}

Amostras de lixiviado foram coletadas no tanque de recepção de um aterro controlado. $\mathrm{O}$ aterro encontra-se atualmente encerrado após 22 anos de operação, quando recebeu diariamente 180 toneladas de resíduos sólidos domésticos e 1,5 toneladas de resíduos provenientes da área de saúde (Vasconcelos, 2014). As coletas foram realizadas sempre no mesmo ponto e em diferentes épocas do ano, o que possibilitou avaliar as mudanças nas características do lixiviado. As amostras eram coletadas em bombonas de 20 litros. Geralmente, a coleta era realizada no final da tarde, o efluente era preservado na geladeira até o dia seguinte, e era levado para o laboratório, onde já eram iniciadas as análises. Os parâmetros de caracterização foram: $\mathrm{pH}$, cloreto, DQO, Demanda Bioquímica de Oxigênio (DBO), Carbono Orgânico Total (COT), Absorbância a $254 \mathrm{~nm}\left(\mathrm{Abs}_{254}\right)$ e cor, segundo metodologia constante no Standard Methods (APHA, 2005). 


\subsection{Processo de coagulação/floculação}

$\mathrm{O}$ processo de coagulação/floculação foi realizado em duas etapas: definição do $\mathrm{pH}$ (volume de $300 \mathrm{~mL}$ de lixiviado, concentração do coagulante $200 \mathrm{mg} \mathrm{FeCl}_{3} \mathrm{~L}^{-1}$ ), no qual variouse o pH (4 a 9) a fim de encontrar o ponto ótimo de eficiência de remoção de DQO e redução da Abs254 (parâmetro que avalia a presença de substâncias orgânicas, em sua maioria orgânicos aromáticos, que absorvem luz em comprimento de onda de $254 \mathrm{~nm}$, região do UV - APHA, 2005); e variação da concentração de cloreto férrico (100 a $600 \mathrm{mg} \mathrm{L}^{-1}$ a partir do $\mathrm{pH}$ ótimo) avaliando os mesmos parâmetros.

Todos os ensaios foram realizados no Jar Test (Nova Ética), a uma rotação de 150 rpm pelo tempo de 1 minuto durante a mistura rápida e a 20 minutos durante a mistura lenta a $20 \mathrm{rpm}$.

\subsection{Adsorção com carvão ativado em pó}

Foi utilizado CAP da marca Carbomafra, (Tipo: $117 \mathrm{CB}$ AS no40), de origem vegetal e fabricação nacional. A metodologia do tratamento utilizada foi adaptada de Maia (2012), onde se variaram as concentrações de carvão em 0,$1 ; 0,4 ; 0,7 ; 1,0 ; 3,0 ; 5,0 \mathrm{~g} \mathrm{~L}^{-1}$. Os testes foram executados em erlenmeyers com efluente e CAP, deixando em contato por 24 horas em constante agitação de $250 \mathrm{rpm}$ em mesa agitadora a $25^{\circ} \mathrm{C}$. Após as 24 horas, as amostras foram filtradas em papel filtro e feitas análises de COT, DQO e Abs254.

\subsection{Reação de Fenton}

Foram fixadas, inicialmente, as relações DQO lixiviado bruto: $\mathrm{H}_{2} \mathrm{O}_{2}$ em 1:1, 1:2 e 1:5. Para cada relação, foram utilizadas diferentes razões $\mathrm{Fe}^{+2}: \mathrm{H}_{2} \mathrm{O}_{2}$, a saber, 1:3, 1:5 e 1:10.

Após duas horas, as amostras foram retiradas do meio reacional, alcalinizadas com solução de hidróxido de sódio $\left(40 \mathrm{~g} \mathrm{~L}^{-1}\right)$ e decantadas para análise. $\mathrm{O}$ teor de peróxido residual foi analisado através de análise colorimétrica de reação com metavanadato de amônio, visto que ele causa interferência na determinação da DQO (Costa et al., 2015).

\subsection{Testes de biodegradabilidade aeróbia}

A metodologia utilizada para o teste de biodegradabilidade aeróbia foi Método de Zahn-Wellens, adotada pela OECD - Organisation For Economic Co-Operation And Development (1992), e consiste em analisar a biodegradabilidade aeróbia de um determinado efluente. Foram utilizados biorreatores (erlenmeyer de $2 \mathrm{~L}$ ) que continham: $500 \mathrm{~mL}$ de meio mineral, uma certa quantidade de efluente que atingisse uma DQO de $1.000 \mathrm{mg} \mathrm{L}^{-1}$, e um volume específico de lodo de uma ETE (Estação de Tratamento de Esgoto) situada no Estado do Rio de Janeiro, para atingir uma concentração de 4,0 $\mathrm{g} \mathrm{L}^{-1}$ de Sólidos Suspensos Voláteis (SSV). Foram utilizadas bombas de aquário com difusores para o fornecimento de ar dissolvido. Para o bloqueio da luz, foi utilizado papel laminado envolto nos erlenmeyers; e para o controle de $\mathrm{pH}$, foram utilizadas soluções de $\mathrm{NaOH}\left(40 \mathrm{~g} \mathrm{~L}^{-1}\right)$ e $\mathrm{H}_{2} \mathrm{SO}_{4}\left(50 \mathrm{~g} \mathrm{~L}^{-1}\right)$ (Soares, 2013).

Os testes de biodegradabilidade foram realizados em duplicata, e conduzidos em biorreatores alimentados da seguinte forma:

- Branco (somente meio mineral + lodo);

- Controle: solução de glicose com DQO equivalente a $1000 \mathrm{mg} \mathrm{L}^{-1}+$ lodo.

- Lixiviado bruto + lodo;

- Lixiviado tratado por Coagulação/Floculação + lodo;

- Lixiviado tratado por Adsorção em Carvão Ativado + lodo; e

- Lixiviado tratado por Fenton + lodo. 
O ensaio em branco foi utilizado para descartar possíveis contribuições que o lodo e o meio mineral possam gerar no sistema reacional e a solução de glicose foi utilizada para servir como controle do lodo, para verificar se o mesmo se apresenta ativo.

\section{RESULTADOS E DISCUSSÃO}

\subsection{Caracterização do lixiviado}

Os resultados de caracterização obtidos das amostras de lixiviado bruto coletadas no tanque de retenção do aterro controlado em diferentes épocas do ano estão apresentados na Tabela 1.

Tabela 1. Caracterização do lixiviado bruto do aterro controlado (RJ).

\begin{tabular}{lccccccc}
\hline Parâmetros & $21 / 03 / 13$ & $22 / 08 / 13$ & $09 / 01 / 14$ & $23 / 01 / 14$ & $20 / 02 / 14$ & $20 / 03 / 14$ & $29 / 05 / 14$ \\
\hline $\mathrm{pH}$ & 8,4 & 8,5 & 8,3 & 8,6 & 8,5 & 8,2 & 8,2 \\
$\begin{array}{l}\text { Cloreto } \\
\left(\mathrm{mg} \mathrm{L}^{-1}\right)\end{array}$ & 791 & 1.641 & 1.377 & 1.321 & 2.001 & 1.732 & 1.608 \\
$\begin{array}{l}\text { DQO } \\
\left(\mathrm{mg} \mathrm{L}^{-1}\right)\end{array}$ & 550 & 7.400 & 2.023 & 1.920 & 2.836 & 5.875 & 3.041 \\
$\begin{array}{l}\text { Cor } \\
\left(\mathrm{mgPtCo} \mathrm{L}^{-1}\right)\end{array}$ & 6.800 & 5.700 & 6.783 & 6.416 & 6.300 & 5.083 & 6.504 \\
$\begin{array}{l}\text { Abs } 254 \\
\mathrm{COT}_{\left(\mathrm{mg} \mathrm{L}^{-1}\right)}\end{array}$ & $\mathrm{NA}$ & 17,9 & 16,5 & 15,1 & 16,5 & 46,06 & 25,16 \\
$\begin{array}{l}\text { DBO } \\
\left(\mathrm{mg} \mathrm{L}^{-1}\right)\end{array}$ & 154 & 506 & NA & 441,8 & 486,2 & 751,5 & 706,5 \\
\hline \begin{tabular}{l} 
Clima \\
\hline
\end{tabular} & Chuvoso & Seco & Seco & Chuvoso & Seco & Seco & Seco \\
\hline
\end{tabular}

NA: Não Avaliado.

Os resultados mostram que este lixiviado apresenta características de um efluente de difícil tratamento, em especial devido à elevada concentração de matéria orgânica recalcitrante (baixa relação DBO/DQO, 0,23). Essa análise indica que o efluente precisaria passar por um pré-tratamento antes de ser tratado biologicamente, para aumentar a relação a biodegradabilidade.

Segundo Gomes (2009), estas características confirmam que o lixiviado é oriundo de resíduos mais estabilizados, pois nestas condições há a presença de ácidos fúlvicos e húmicos, compostos de difícil degradação biológica. Esses ácidos contribuem para a coloração escura do lixiviado, que pôde ser observada em todas as amostras e é confirmada pelos valores elevados de cor e Abs254.

Esse resultado já era esperado, visto que o aterro encontra-se fechado desde 2012 e que a linha de alimentação do tanque de retenção é oriunda de células mais antigas. Pode ser observado, também, o pH levemente básico superior a 8 em todas as coletas. 


\subsection{Coagulação/Floculação}

A Tabela 2 ilustra os resultados obtidos durante a otimização do $\mathrm{pH}$ e concentração do coagulante durante a realização do processo de coagulação/floculação.

Tabela 2. Resultados dos testes de otimização de $\mathrm{pH}$ e concentração de coagulante $\left(\mathrm{FeCl}_{3}\right)$ utilizando lixiviado com DQO inicial de $1031 \mathrm{mg} \mathrm{L}^{-1}$ Abs254 de 17,9 e pH inicial de 8,5. Condições dos ensaios: mistura rápida, $150 \mathrm{rpm}$ por 1 minuto e mistura lenta, $20 \mathrm{rpm}$ por 20 minutos.

\begin{tabular}{|c|c|c|c|c|c|}
\hline \multicolumn{6}{|c|}{ Otimização do pH } \\
\hline $\mathrm{pH}$ & $\begin{array}{l}\text { Coagulante } \\
\left(\mathrm{mg} \mathrm{FeCl}_{3} \mathrm{~L}^{-1}\right)\end{array}$ & $\mathrm{Abs}_{254}$ & $\begin{array}{l}\text { Redução da } \\
\operatorname{Abs}_{254}(\%)\end{array}$ & $\begin{array}{c}\mathrm{DQO} \\
\left(\mathrm{mg} \mathrm{L}^{-1}\right)\end{array}$ & $\begin{array}{l}\text { Eficiência de } \\
\text { remoção de } \\
\text { DQO }(\%)\end{array}$ \\
\hline 4 & \multirow{6}{*}{200} & 0,48 & 97,3 & 756 & 26,7 \\
\hline 5 & & 0,58 & 96,7 & 858 & 16,7 \\
\hline 6 & & 0,55 & 96,9 & 906 & 12,1 \\
\hline 7 & & 0,66 & 96,3 & 921 & 10,6 \\
\hline 8 & & 0,82 & 95,4 & 913 & 11,5 \\
\hline 9 & & 0,82 & 95,4 & 917 & 11,1 \\
\hline \multicolumn{6}{|c|}{ Otimização da concentração de coagulante } \\
\hline $\begin{array}{c}\text { Coagulante } \\
\left(\mathrm{mg} \mathrm{FeCl}_{3} \mathrm{~L}^{-1}\right)\end{array}$ & $\mathrm{pH}$ & $\mathrm{Abs}_{254}$ & $\begin{array}{l}\text { Redução da } \\
\operatorname{Abs}_{254}(\%)\end{array}$ & $\begin{array}{c}\mathrm{DQO} \\
\left(\mathrm{mg} \mathrm{L}^{-1}\right)\end{array}$ & $\begin{array}{l}\text { Eficiência de } \\
\text { remoção de } \\
\text { DQO }(\%)\end{array}$ \\
\hline 100 & \multirow{6}{*}{4,0} & 0,49 & 97,3 & 898 & 12,9 \\
\hline 200 & & 0,48 & 97,3 & 752 & 27,1 \\
\hline 300 & & 0,47 & 97,4 & 795 & 22,9 \\
\hline 400 & & 0,44 & 97,5 & 830 & 19,5 \\
\hline 500 & & 0,40 & 97,8 & 849 & 17,7 \\
\hline 600 & & 0,40 & 97,8 & 728 & 29,4 \\
\hline
\end{tabular}

Na primeira etapa, o pH igual a 4 foi a condição que apresentou a maior eficiência na remoção da DQO e Abs254. Destaca-se a elevada redução da Abs254 em pH 4 de, aproximadamente, 97\%. Dessa maneira, esse valor de $\mathrm{pH}$ foi escolhido para etapa seguinte.

A concentração de cloreto férrico que apresentou a maior eficiência de remoção em relação à DQO foi $600 \mathrm{mg} \mathrm{L}^{-1}$, porém as concentrações de 200 e $300 \mathrm{mg} \mathrm{L}^{-1}$ também apresentaram resultados significativos, na de 22 a $27 \%$ de remoção. Entretanto, para aplicação de $300 \mathrm{mg} \mathrm{FeCl}_{3} \mathrm{~L}^{-1}$ foi alcançada remoção de $64 \%$ de COT e para $200 \mathrm{mg} \mathrm{FeCl} \mathrm{L}^{-1}, 38,9 \%$ (resultados não mostrados na Tabela 2). Sendo assim, como melhores condições de tratamento desse lixiviado, foram eleitos o $\mathrm{pH}$ igual a 4 e $300 \mathrm{mg} \mathrm{FeCl}_{3} \mathrm{~L}^{-1}$.

Marañón et al. (2008), utilizando $400 \mathrm{mg} \mathrm{FeCl}_{3} \mathrm{~L}^{-1}$, obtiveram uma eficiência de remoção de DQO de 28,1\%, valor próximo aos encontrados nesse estudo. Esse resultado decorre, provavelmente, devido à operação do aterro, pois o aterro espanhol operava do mesmo modo que $o$ aterro do presente trabalho.

De acordo com os trabalhos de Ferreira e Campos (2014) e Gewehr (2012), que obtiveram $60 \%$ e $63 \%$ de eficiência de remoção de DQO, respectivamente, pode-se verificar que os resultados dos testes de coagulação/floculação obtidos neste estudo, em geral, apresentaram uma baixa eficiência de remoção de DQO, porém, esse fato pode ser devido à composição química variada do lixiviado e dos resíduos enterrados. 


\subsection{Adsorção em carvão ativado}

A Tabela 3 ilustra os resultados dos ensaios de adsorção usando o carvão ativado em pó em diferentes concentrações.

Alguns ensaios mostraram significativas eficiências de remoção de DQO, sendo as melhores obtidas com as concentrações de 3 e $5 \mathrm{~g} \mathrm{~L}^{-1}$ de CAP. Aghamohammadi et al. (2007) e Kargi e Uygur (2004) utilizaram $3 \mathrm{~g} \mathrm{~L}^{-1}$ e $5 \mathrm{~g} \mathrm{~L}^{-1}$, respectivamente, de CAP (de diferentes procedências) para tratar o lixiviado. Ambos os autores encontraram uma eficiência de remoção de $49 \%$ de DQO, um pouco abaixo do que encontrado no presente trabalho, mas mesmo assim mostra que a adsorção ao CAP pode ser uma alternativa promissora para a remoção de matéria orgânica do efluente em questão.

Tabela 3. Resultados dos testes de adsorção com carvão ativado em pó após 24 horas de contato e sob agitação de $250 \mathrm{rpm}$, Carbomafra, (Tipo: $117 \mathrm{CB}$ AS nº40).

\begin{tabular}{ccc}
\hline $\begin{array}{c}\text { CAP } \\
\left(\mathrm{g} \mathrm{L}^{-1}\right)\end{array}$ & $\begin{array}{c}\text { DQO } \\
\left(\mathrm{mg} \mathrm{L}^{-1}\right)\end{array}$ & $\begin{array}{c}\text { Eficiência de remoção } \\
\text { de DQO }(\%)\end{array}$ \\
\hline Lixiviado bruto & 2600 & -- \\
0,1 & 1740 & 33,1 \\
0,4 & 1404 & 46,0 \\
0,7 & 1309 & 49,7 \\
1,0 & 1304 & 49,8 \\
3,0 & 976 & 62,5 \\
5,0 & 805 & 69,0 \\
\hline
\end{tabular}

Em geral, os ensaios com carvão ativado mostraram significativas eficiências de remoção, porém quando foram utilizadas dosagem maiores, 3 e $5 \mathrm{~g} \mathrm{~L}^{-1}$ de CAP, foram alcançadas as melhores eficiências na remoção da DQO.

De acordo com o Cotman e Gotvajn (2010), o tratamento utilizando carvão ativado apresenta boa eficiência de remoção da DQO, onde os autores obtiveram $86 \%$ de remoção usando uma dosagem de $50 \mathrm{~g} \mathrm{~L}^{-1}$. Entretanto, deve-se considerar que o emprego de dosagens elevadas pode dificultar a aplicação dessa técnica de tratamento no aterro, considerando os custos elevados de um sistema de tratamento em escala real e a regeneração do CAP.

\subsection{Reação de Fenton}

Para a avaliação da remoção da matéria orgânica, inicialmente foram estabelecidas as relações DQOLIXIVIADO BRUTO: $\mathrm{H}_{2} \mathrm{O}_{2}$ e para cada valor dessa relação foram variadas as relações de $\mathrm{Fe}^{+2}: \mathrm{H}_{2} \mathrm{O}_{2}$. O tempo de reação $(2 \mathrm{~h})$ e o $\mathrm{pH}$ (3) foram fixados em valores usuais de acordo com a literatura. Em uma segunda etapa, foi avaliada a relação DQOLIXIVIADO BRUTo: $\mathrm{H}_{2} \mathrm{O}_{2}$ de 1:0,5. A Tabela 4 ilustra os resultados de eficiência de remoção da DQO para os experimentos utilizando o Reativo de Fenton.

As porcentagens de remoção da DQO foram todas maiores que $50 \%$ em todas as condições testadas e percebe-se que quanto menor a quantidade de ferro na reação, menor a remoção de DQO e maiores as concentrações de peróxido residual no efluente. Esse cenário se dá porque o ferro é o catalisador responsável pela formação dos radicais hidroxila, os quais favorecem a oxidação da matéria orgânica.

Observando-se os resultados, quando a quantidade de peróxido aumenta (relação DQO: $\mathrm{H}_{2} \mathrm{O}_{2}$ de 1:2 e 1:5), aumentam-se as quantidades de reagentes, mas a eficiência de remoção de DQO não acompanha na mesma proporção. Então, para confirmar os resultados anteriores foi 
utilizada uma nova amostra de lixiviado e realizados ensaios com relação DQO: $\mathrm{H}_{2} \mathrm{O}_{2}$ igual a 1:1 e 1:0,5, mantendo-se a proporção de $\mathrm{Fe}: \mathrm{H}_{2} \mathrm{O}_{2}$ de 1:3. Os resultados podem ser observados na última linha da Tabela 4.

Tabela 4. Resultados dos ensaios do Reativo de Fenton utilizando pH igual a 3 e $2 \mathrm{~h}$ de reação.

\begin{tabular}{|c|c|c|c|c|c|c|c|}
\hline $\begin{array}{l}\text { DQO } \\
\text { LIXIVIADO } \\
\text { BRUTO } \\
\left(\mathrm{mg} \mathrm{L}^{-1}\right)\end{array}$ & $\begin{array}{l}\text { DQO: } \\
\mathrm{H}_{2} \mathrm{O}_{2}\end{array}$ & $\begin{array}{c}\mathrm{Fe}: \\
\mathrm{H}_{2} \mathrm{O}_{2}\end{array}$ & $\begin{array}{c}\mathrm{H}_{2} \mathrm{O}_{2} \\
\left(\mathrm{mg} \mathrm{L}^{-1}\right)\end{array}$ & $\begin{array}{l}\mathrm{Fe}^{2+} \\
\left(\mathrm{mg} \mathrm{L}^{-1}\right)\end{array}$ & $\begin{array}{c}\mathrm{H}_{2} \mathrm{O}_{2} \text { residual } \\
\left(\mathrm{mg} \mathrm{L}^{-1}\right)\end{array}$ & $\begin{array}{l}\text { DQO final* } \\
\left(\mathrm{mg} \mathrm{L}^{-1}\right)\end{array}$ & $\begin{array}{l}\text { Eficiência de } \\
\text { remoção de } \\
\text { DQO }(\%)\end{array}$ \\
\hline \multirow{6}{*}{2023} & \multirow{3}{*}{$1: 1$} & $1: 3$ & \multirow{3}{*}{2.023} & 674,3 & 78 & 436 & 78,4 \\
\hline & & $1: 5$ & & 404,6 & 190 & 581 & 71,3 \\
\hline & & $1: 10$ & & 202,3 & 570 & 847 & 58,1 \\
\hline & \multirow{3}{*}{$1: 2$} & $1: 3$ & \multirow{3}{*}{4.046} & $1.348,7$ & 53 & 358 & 82,3 \\
\hline & & $1: 5$ & & 809,2 & 523 & 521 & 74,2 \\
\hline & & $1: 10$ & & 404,6 & 597 & 484 & 76,0 \\
\hline \multirow{3}{*}{1702} & \multirow{3}{*}{$1: 5$} & $1: 3$ & \multirow{3}{*}{8.510} & $2.836,7$ & 68 & 343 & 79,8 \\
\hline & & $1: 5$ & & $1.702,0$ & 452 & 340 & 80,0 \\
\hline & & $1: 10$ & & 851,0 & 990 & 381 & 77,6 \\
\hline \multirow{2}{*}{2490} & $1: 1$ & $1: 3$ & 2.490 & 830,0 & 181 & 655 & 73,7 \\
\hline & $1: 0,5$ & $1: 3$ & 1.245 & 415,0 & 146 & 896 & 64,0 \\
\hline
\end{tabular}

*corrigida, descontando a parcela referente ao peróxido residual.

Comparando os dois testes feitos para relação DQO/ $\mathrm{H}_{2} \mathrm{O}_{2}$ igual a $1 / 1$ pode-se observar que o ensaio que utilizou menor quantidade de $\mathrm{H}_{2} \mathrm{O}_{2}$ resultou em elevada concentração de peróxido residual, diferentemente do obtido no primeiro ensaio. O resultado de remoção de DQO para a relação DQO: $\mathrm{H}_{2} \mathrm{O}_{2}$ igual a 1:1 foi similar ao anterior (com outra amostra de lixiviado). Porém, para a menor concentração de peróxido, a remoção de DQO foi diminuída em quase dez pontos percentuais.

Outros autores obtiveram em suas pesquisas eficiências maiores que $80 \%$, no entanto, utilizaram relações Fe: $\mathrm{H}_{2} \mathrm{O}_{2}$ maiores. Como exemplo, Costa et al. (2015) obteve eficiência de remoção de DQO igual a $88 \%$ utilizando a relação $\mathrm{Fe}^{2+}: \mathrm{H}_{2} \mathrm{O}_{2}$ igual a 1:5 com tempo de reação de 60 minutos.

\subsection{Testes de biodegradabilidade aeróbia}

Para avaliar se os tratamentos pesquisados tiveram efeito na biodegradabilidade do lixiviado, foram realizados testes de biodegradabilidade aeróbia para o efluente tratado por coagulação/floculação, adsorção em carvão ativado e Fenton, nas suas melhores condições. Conforme Tabela 5, os resultados apresentados são médias da duplicata realizada. Ressalta-se que os resultados não diferiram em menos de $10 \%$ entre eles e todos os ensaios foram realizados em amostras diferentes de lixiviado.

O lixiviado bruto apresentou resultados diferentes no teste de biodegradabilidade. Isso se deve ao fato de que para cada teste uma nova amostra era coletada, e os resultados evidenciam a heterogeneidade das características do lixiviado.

No teste 1, o lixiviado bruto apresenta uma boa biodegradabilidade (80\%), superior ao lixiviado pré-tratado (54\%). Isso demonstra que a amostra de lixiviado bruto se apresentou 
muito mais biodegradável que o efluente do processo de coagulação/floculação, e que o mesmo não foi capaz de aumentar a biodegradabilidade do lixiviado.

Para o teste 2 , utilizando efluente após o CAP, a partir do $13^{\circ}$ dia a biodegradabilidade dos efluentes tratados começou a aumentar. A condição com concentração de $5 \mathrm{~g} \mathrm{~L}^{-1}$ de carvão gerou os melhores resultados. Ao fim do tratamento com CAP houve uma remoção de $69 \%$ da DQO, sendo obtidos valores de biodegradabilidade próximos aos do lixiviado bruto $(23 \%)$. Esse resultado comprova que o tratamento não alterou a biodegradabilidade do efluente.

Tabela 5. Resultado de biodegradabilidade aeróbia em 29 dias.

\begin{tabular}{|c|c|c|}
\hline Testes & Amostras e condições do processo & $\begin{array}{l}\text { Biodegradabilidade } \\
\text { aeróbia após } 29 \text { dias (\%) }\end{array}$ \\
\hline \multirow[b]{2}{*}{1} & Lixiviado Bruto (coletado em 22/08/2013) & 80 \\
\hline & $\begin{array}{l}\text { Lixiviado após coagulação/floculação } \\
\left(\mathrm{pH}=4 \text { e } 300 \mathrm{mg} \mathrm{FeCl}_{3} \mathrm{~L}^{-1}\right)\end{array}$ & 54 \\
\hline \multirow{3}{*}{2} & Lixiviado Bruto (coletado em 20/03/2014) & 23 \\
\hline & Lixiviado após adsorção com $3 \mathrm{~g}$ CAP/L & 17 \\
\hline & Lixiviado após adsorção com $5 \mathrm{~g}$ CAP/L & 23 \\
\hline \multirow[b]{2}{*}{3} & Lixiviado Bruto (coletado em 29/05/2014) & 5 \\
\hline & $\begin{array}{l}\text { Lixiviado após Reativo de Fenton } \\
\left(\mathrm{DQO} / \mathrm{H}_{2} \mathrm{O}_{2} \text { de } 1 / 1 \mathrm{e} \mathrm{Fe}^{+2} / \mathrm{H}_{2} \mathrm{O}_{2} \text { de } 1 / 3\right)\end{array}$ & 25 \\
\hline
\end{tabular}

Para os ensaios com efluente tratado pelo processo Fenton (DQO: $\mathrm{H}_{2} \mathrm{O}_{2}$ de 1:1 e Fe: $\mathrm{H}_{2} \mathrm{O}_{2}$ de 1:3), a biodegradabilidade foi maior que o lixiviado bruto. Destaca-se, neste caso, a maior recalcitrância do lixiviado bruto perante aos anteriores. Apesar disso, a reação de Fenton conseguiu aumentar a biodegradabilidade do lixiviado.

\section{CONCLUSÕES}

Ao todo foram coletadas sete amostras de lixiviado em diferentes épocas do ano no tanque de retenção de um aterro controlado no Estado do Rio de Janeiro, o que permitiu avaliar o comportamento da composição do líquido ao longo do tempo. Por se tratar de um aterro controlado, onde as condições de operação do aterro não são as ideiais, percebeu-se grande variabilidade nas características do lixiviado.

Após definidas as condições ótimas de tratamento do lixiviado por coagulação/floculação ( $\mathrm{pH}=4$ e $300 \mathrm{mg} \mathrm{FeCl}_{3} \mathrm{~L}^{-1}$ ), obteve-se uma remoção de 22,9\% da DQO e 64\% do COT.

Duas condições ótimas do processo de adsorção em carvão ativado em pó no tratamento do lixiviado foram estabelecidas, com 3 e $5 \mathrm{~g} \mathrm{~L}^{-1}$ de carvão, e essas condições obtiveram eficiências de remoção da DQO de $62,5 \%$ e $69 \%$, respectivamente.

A Reação de Fenton foi o tratamento que apresentou as melhores porcentagens de remoção, obtendo eficiências de remoção de DQO entre 58,12 a 82,30\%, sendo a escolhida como melhor condição a que utilizou as relações DQO: $\mathrm{H}_{2} \mathrm{O}_{2}$ igual a $1: 1$ e $\mathrm{Fe}: \mathrm{H}_{2} \mathrm{O}_{2}$ igual $1: 3$ e obteve $78,42 \%$ de remoção, pois esta utilizou menor concentração de ferro e peróxido de hidrogênio.

Nos testes de biodegradabilidade aeróbia, a Reação de Fenton levou a um aumento da biodegradabilidade do lixiviado nas condições de DQO $: \mathrm{H}_{2} \mathrm{O}_{2}$ de $1: 1$ e $\mathrm{Fe}^{2+}: \mathrm{H}_{2} \mathrm{O}_{2}$ de 1:3. 


\section{AGRADECIMENTOS}

À FAPERJ (Fundação Carlos Chagas Filho de Amparo à Pesquisa do Estado do Rio de Janeiro) pelo auxílio financeiro para a pesquisa.

\section{REFERÊNCIAS}

AGHAMOHAMMDI, N.; AZIZ, H. A; ISA, M.H.; ZINATIZADEH, A. A. Powdered activated carbon augmented activated sludge process for treatment of semi-aerobic landfill leachate using response surface methodology. Bioresource Technology, v. 98, n.18, , p. 35103578, 2007. http://dx.doi.org/10.1016/j.biortech.2006.11.037

AMERICAN PUBLIC HEALTH ASSOCIATION - APHA. Standard Methods for the Examination of Water and Wastewater. 21. ed. Washington, DC, 2005.

CHEIBUB, A.F.; CAMPOS, J.C; FONSECA, F.V. Removal of COD from a stabilized landfill leach ate by physicochemical and Advanced Oxidative Process Journal of Environmental Science and Health Part A Toxic/Hazardous Substances \& Environmental Engineering, v. 49, n. 14, p. 1718-1726, 2014. http://dx.doi.org/10.1080/10934529.2014.951259

COSTA, F. M.; CAMPOS, J. C.; FONSECA, F. V.; BILA, D. M. Tratamento de lixiviados de aterros de resíduos sólidos utilizando Processos Fenton e Foto-Fenton Solar. Revista Ambiente \& Água, v.10, n.1, 2015. http://dx.doi.org/10.4136/ambi-agua.1483

COTMAN, M.; GOTVAJN, A.Z. Comparison of different physic-chemical methods for the removal of toxicants landfill leachate. Journal of Hazardous Materials, v. 178, n. 1-3, p. 208-305, 2010. http://dx.doi.org/10.1016/j.jhazmat.2010.01.078

DENG, J.; ENGLEHARDT, J.D. Treatment of landfill leachate by the Fenton process. Water Research, v. 40, n.20, p. 3683-3694, 2006. http://dx.doi.org/10.1016/j.watres.2006.08.009

FENTON, H. J. H. Oxidation of tartaric acid in presence of iron. Journal of the Chemical Society, Transactions, v. 65, n. 141, p. 899-910, 1894. http://dx.doi.org/10.1039/CT8946500899

FERREIRA, D. S.; CAMPOS, J.C. Estudo comparativo da coagulação-floculação e eletrocoagulação no tratamento de lixiviado de Aterro Sanitário. In: SIMPOSIO ITALOBRASILEIRO DE ENGENHARIA SANITÁRIA E AMBIENTAL, 12., 19-21 maio. Natal. Anais... Natal: ABES, 2014. 1 CD-ROM.

GEWEHR, A.G. Tratamento por Coagulação/Floculação de Lixiviado Bruto de Aterro Sanitário com e sem Pré-Tratamento Biológico em Reator Sequencial em Batelada. 2012. 163f. Dissertação (Mestrado em Recursos Hídricos e Saneamento) - Universidade Federal do Rio Grande do Sul, Porto Alegre, 2012.

GOMES, L. P. (Org) PROSAB, Programa de Pesquisa em Saneamento Básico. Edital 5. Resíduos sólidos: estudos de caracterização e tratabilidade de lixiviados de aterros sanitários para as condições brasileiras. Rio de Janeiro: ABES, 2009. 362 p.

KARGI, F.; UYGUR, A. Biological nutrient removal from pre-treated landfill leach ate in a sequencing batch reactor. Journal of Environmental Management, v. 71, n.1, p. 9-14, 2004. http://dx.doi.org/10.1016/j.jenvman.2004.01.002 
LI, W.; HUA, T.; ZHOU, Q.; ZHANG, S.; LI., F. Treatment of stabilized landfill leachate by the combined process of coagulation/flocculation and powder activated carbon adsorption. Desalination, v. 264, n. 1-2, p. 56-62, 2010.

http://dx.doi.org/10.1016/j.desal.2010.07.004

MAIA, L. S. Uso de carvão ativado em pó no tratamento biológico de lixiviado de aterro de resíduos. 2012. 177f. Dissertação (Mestrado em Tecnologia de Processos Químicos e Bioquímicos) - Universidade Federal do Rio de Janeiro, Rio de Janeiro, 2012.

MARAÑÓN, E.; CASTRILLÓN, L.; FERNÁNDEZ-NAVA, Y.; FERNÁNEZ-MÉNDEZ, A.; FERNÁNDEZ-SANCHÉZ, A. Coagulation-flocculation as a pretreatment processat a landfill leach ate nitrification-denitrification plant. Journal of Hazardous Materials, v. 156, n. 1-3, p. 538-544, 2008. http://dx.doi.org/10.1016/j.jhazmat.2007.12.084

METCALF \& EDDY INC. Wastewater engineering: treatment and reuse. 4th ed. New York: McGraw-Hill, 2003. 1819p.

MORAVIA, W. G.; LANGE, L. C.; AMARAL, M. C. S. Avaliação de processo oxidativo avançado pelo reagente de fenton em condições otimizadas no tratamento de lixiviado de aterro sanitário com ênfase em parâmetros coletivos e caracterização do lodo gerado. Química Nova, v. 34, n. 8, 2011.

ORGANIZATION FOR ECONOMIC CO-OPERATION AND DEVELOPMENT - OECD. OECD Guideline for Testing of Chemicals. Zahn-Wellens. Paris, 1992. Disponível em: https://www.oecd.org/env/ehs/testing/E302B.pdf . Acesso em: 11 jun.2016.

QUEIROZ, L. G.; FREIRE, L. F. A.; ARAUJO, F. V. F.; YOKOYAMA, L.; CAMPOS, J. C. Estudo do processo Fenton e Foto-Fenton no tratamento de lixiviados de aterros sanitários. In: CONGRESSO BRASILEIRO DE ENGENHARIA SANITÁRIA E AMBIENTAL, 26., 2011, Porto Alegre. Anais... Rio de Janeiro: ABES, 2011. v. 1. p. 1 5.

SÁ, L. F.; JUCÁ, F. T.; SOBRINHO, M. A. M. Tratamento do lixiviado de aterro sanitário usando destilador solar. Revista Ambiente \& Água, v.07, n.1, 2012. http://dx.doi.org/10.4136/ambi-agua.81

SOARES, C. I. S. Ensaio de biodegradabilidade aeróbia para apoio à operação de Contactor Biológico Rotatório tratando lixiviados. 2013. 114f. Dissertação (Mestrado em Engenharia Civil) - Universidade do Vale dos Sinos, São Leopoldo, 2013.

VASCONCELOS, D.V. Estudo da tratabilidade do lixiviado gerado no aterro controlado de Volta Redonda(RJ). 2014. 66f. Dissertação (Mestrado em Engenharia Ambiental) - Escola Politécnica, Universidade Federal do Rio de Janeiro, Rio de Janeiro, 2014.

ZHANG, H.; WU, X.; LI, X. Oxidation and coagulation removal of COD from landfill leachate by Fered-Fenton process. The Chemical Engineering Journal, v. 210, n.1, p.188-194, 2012. http://dx.doi.org/10.1016/j.cej.2012.08.094 


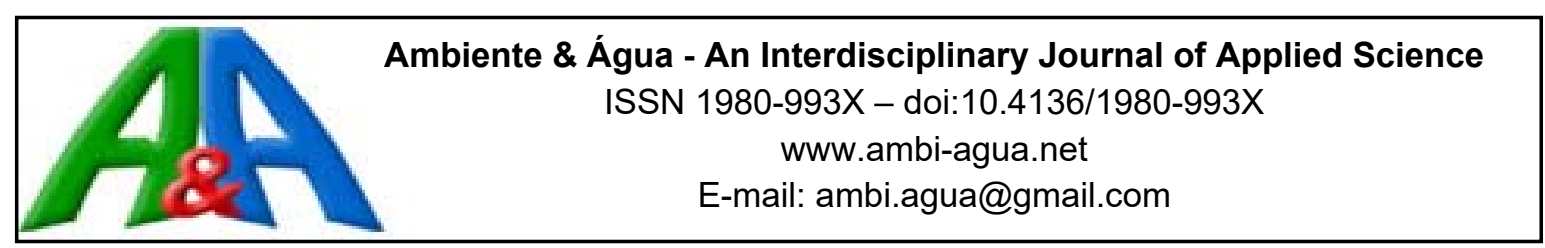

\title{
Análise bacteriológica da água de consumo comercializada por caminhões-pipa
}

\author{
doi:10.4136/ambi-agua.1934
}

Received: 08 May. 2016; Accepted: 18 Feb. 2017

\author{
Maria Helena Martins Mendonça ${ }^{1}$; Sthefany Angely Moraes Roseno'; \\ Thayany Ruanny Leite Cachoeira ${ }^{1}$; Ákylla Fernanda Souza Silva ${ }^{1}$; \\ Paula Regina Luna de Araújo Jácome ${ }^{2}$; Agenor Tavares Jácome Júnior ${ }^{1 *}$

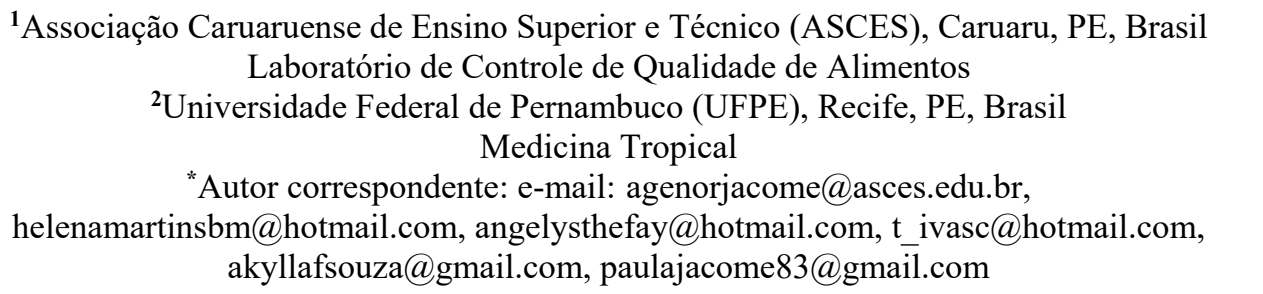

\section{RESUMO}

A garantia do fornecimento de uma água de qualidade destinada ao consumo humano é uma questão relevante para a saúde pública, sobretudo quando a água ofertada é dependente de meios alternativos, como os chamados caminhões-pipa. Entretanto, a grande preocupação quanto a esse tipo de transporte de água está relacionada aos diversos riscos de contaminações que podem ocorrer. Assim, o presente estudo teve como objetivo avaliar a qualidade bacteriológica da água para consumo direto (ingestão) comercializada por caminhões-pipa, destinada ao abastecimento da cidade de Caruaru-PE. Foram analisadas 10 amostras, obtidas de cinco caminhões-pipa, por meio da Técnica dos Tubos Múltiplos, para a identificação de Pseudomonas aeruginosa e do grupo coliforme e, da técnica pour plate, para a contagem de bactérias heterotróficas. Os resultados revelaram a presença dos grupos bacterianos testados na maioria das amostras analisadas. Foi verificado que o tempo era um fator que contribuia para o aumento do índice de contaminação. Conclui-se que esse tipo de comércio acaba fornecendo uma água que não atende aos requisitos de potabilidade e com um alto risco de contaminação, sendo imprópria para o consumo humano.

Palavras-chave: água potável, coliforme, Pseudomonas aeruginosa.

\section{Bacteriological analysis of drinking water sold by water tank trucks}

\begin{abstract}
Assuring the quality of the supply of water for human consumption is important for public health, especially when delivery of the water is dependent on alternative means, such as tanker trucks. The major concern about this kind of water transport is the risk of contamination. This study therefore evaluated the bacteriological quality of water sold by water trucks that supply the city of Caruaru-PE, Brazil. Ten samples from five trucks were analyzed using the technique of multiple tubes for the identification of Pseudomonas aeruginosa and coliform, and the pour plate technique for counting heterotrophic bacteria was also used. The results revealed the
\end{abstract}


presence of bacteria groups in most analyzed samples. Delivery time was a factor that increases the rate of contamination. It can be concluded that this type of delivery provides water that does not meet potability requirements and has a high risk of contamination, resulting in water that is unfit for human consumption.

Keywords: coliforms, potable water, Pseudomonas aeruginosa.

\section{INTRODUÇÃO}

A água é considerada um recurso natural insubstituível, tendo fundamental importância para a manutenção da vida. O controle da qualidade da água é uma necessidade universal, que exige atenção por parte das autoridades sanitárias e dos consumidores em geral, sobretudo no que se refere à água destinada ao consumo humano, visto que ela pode se tornar um veículo capaz de transmitir uma série de agentes patogênicos e substâncias nocivas influenciando diretamente no bem-estar e na saúde da população (Araújo et al., 2011; Wang et al., 2014).

Caruaru é um município localizado na região do agreste pernambucano, a 130 quilômetros da capital, Recife. Sua população estimada pelo Instituto Brasileiro de Geografia e Estatística no ano de 2015, foi de 347.088 habitantes, com área territorial de $920,611 \mathrm{~km}^{2}$ (IBGE, 2015). É prática comum no município a comercialização de água, dita "potável e mineral", em caminhões transportando até seis containers (cujas especificações são para transporte de peixe vivo) com capacidade para $1.000 \mathrm{~L}$ de água. Essa água é obtida diretamente de fontes naturais, sendo coletadas de aquíferos subterrâneos da região. A água captada passa por uma etapa de cloração e em seguida é livremente vendida em garrafões com capacidade para $20 \mathrm{~L}$, sendo a água envasada apenas no momento da sua comercialização.

Os caminhões que fazem o transporte da água para o consumo ou outras finalidades de uso doméstico (caminhões-pipa) devem garantir que a água distribuída seja potável e seguir todos os procedimentos citados na Portaria 2914/11 (MS) estabelecido no Artigo 15. Essa mesma portaria estabelece os padrões de potabilidade para essas águas, de modo que o seu consumo não ofereça riscos à saúde. Entretanto, a grande preocupação quanto ao comércio da água para o consumo em caminhões-pipa é referente aos diversos riscos de contaminações que ela está exposta, podendo ser comercializada fora dos padrões de qualidade e ainda servir como propagadora de diversas doenças (Carvalho, 2015).

Nesse sentido, o monitoramento da qualidade bacteriológica da água para consumo deve ser realizado a fim de se avaliar se ela se encontra dentro dos padrões de potabilidade humana, que requer uma água limpa e livre de patógenos ou qualquer outro tipo de contaminação que cause danos à saúde (Müller e Parussolo, 2014). Para que essa qualidade seja estabelecida, são utilizados como parâmetro, micro-organismos indicadores de contaminação fecal, como o grupo Coliforme, tendo como principal representante a Escherichia coli, que avalia suas condições higiênicas evidenciando uma possível contaminação fecal recente (Coelho et al., 2010; Cavalcante, 2014; Silva et al., 2016).

Além do grupo coliforme, a pesquisa da bactéria Pseudomonas aeruginosa, em ambientes aquáticos, tem-se mostrado de grande importância, sobretudo em águas destinadas ao consumo humano, como as águas minerais (Almeida et al., 2009; Pedrosa et al., 2014). Trata-se de um bacilo gram-negativo, sendo classificado como um dos micro-organismos mais versáteis e oportunistas. Sua presença está relacionada às diversas causas de infecções devido à colonização de dispositivos médicos e a consequente formação de biofilme, ocasionando em importantes complicações clínicas e elevados custos associados ao manejo dos pacientes (Quatrin et al., 2015).

Levando em consideração que o consumo de uma água fora dos padrões estabelecidos pela legislação pode ocasionar diversos riscos à saúde da população, o presente trabalho teve como 
objetivo avaliar a qualidade bacteriológica das águas para consumo direto (ingestão) comercializadas em "Caminhões-pipa" do município de Caruaru-PE. A determinação da qualidade bacteriológica das águas será realizada pesquisando-se a presença de indicadores de contaminação fecal (grupo coliforme), de contaminação por material orgânico (a espécie Pseudomonas aeruginosa) e pela contagem de bactérias heterotróficas nas amostras de água coletadas.

\section{MATERIAL E MÉTODOS}

\subsection{Tipologia do estudo, coleta e amostragem}

O presente estudo possuiu um desenho experimental laboratorial. $\mathrm{O}$ universo da pesquisa foi composto por amostras de água para consumo direto (ingestão) comercializadas em "caminhões-pipa" na cidade de Caruaru-PE. As coletas foram realizadas no mês de dezembro de 2015 a fevereiro de 2016, sendo coletadas 10 amostras de água obtidas de 5 caminhões-pipa em diferentes pontos da Cidade de Caruaru-PE. As amostras foram coletadas em dois horários distintos, sendo das $09: 00 \mathrm{~h}$ às $11: 00 \mathrm{~h}$ para a primeira coleta, e das 14:00h às 16:00h para a segunda coleta.

Os critérios de elegibilidade para os caminhões-pipa eram, principalmente, o seu destino de abastecimento por todo o município, sobretudo nos bairros mais populosos; ser um caminhão de médio porte, com capacidade para até seis containers retangulares, que utilizassem para transportar água tanques para transporte de peixe vivo, com capacidade de $1.000 \mathrm{~L}$ em material de polietileno (PE); e que a água neles comercializada fosse advinda das fontes subterrâneas localizadas na reserva do Muricí, situada na zona rural do município de Caruaru-PE.

As amostras foram coletadas em botijões de 20L, previamente higienizados através de assepsia com álcool $70 \%$ e, logo em seguida, as amostras de cada caminhão-pipa eram distribuídas em sacos estéreis com capacidade para $140 \mathrm{~mL}$. Por fim, as amostras eram transportadas sobre refrigeração até o Laboratório de Análise de Água e Bromatologia localizado do Centro Universitário Tabosa de Almeida - ASCES/UNITA, em Caruaru-PE, para a realização das análises bacteriológicas.

\subsection{Análise microbiológica}

As pesquisas de $P$. aeruginosa e do grupo coliforme foram realizadas através da Técnica dos Tubos Múltiplos, método preconizado pelo Standard Methods for the Examination of Water and Wasterwater (APHA et al., 2012). As condições de cultivo para a pesquisa de $P$. aeruginosa foi utilizando o Caldo Asparagina em 3 séries de 5 tubos, com incubação de $35^{\circ} \mathrm{C} / 48 \mathrm{~h}$ para a fase presuntiva, e o Caldo Acetamida para a fase confirmatória na mesma temperatura e tempo de incubação. Para a pesquisa de coliformes foram utilizados os meios Caldo Lactosado (ensaio presuntivo) e Caldo Lactosado Verde Brilhante Bile (ensaio confirmatório) incubados à $35^{\circ} \mathrm{C} / 48 \mathrm{~h}$. A contagem de bactérias heterotróficas foi feita de acordo com a técnica de Pour Plate (APHA et al., 2012).

\subsection{Processamento de dados}

As análises dos dados foram conduzidas utilizando o software excel (v. 14.07) no qual foi aplicada uma análise descritiva para obtenção do percentual de positividade das amostras para $P$. aeruginosa, coliformes totais e termotolerantes, e a média e desvio padrão das contagens de bactérias heterotróficas dadas por unidades formadoras de colônias para cada mililitro de água (UFC mL $\mathrm{mL}^{-1}$ ). 


\section{RESULTADOS E DISCUSSÃO}

Os resultados aqui observados demonstraram que a grande maioria (90\%) das amostras de água comercializadas em caminhões-pipa analisadas nessa pesquisa apresentaram contagens de coliformes totais (CT), coliformes termotolerantes (CTo), Pseudomonas aeroginosa e bactérias heterotróficas em desacordo com padrões de potabilidade estabelecidos pela legislação vigente (Tabela 1). Apenas na amostra E, coletada no turno da manhã (E m), foi observada a ausência dos grupos bacterianos analisados, no entanto, a contagem de bactérias heterotróficas ainda

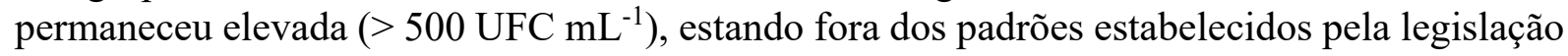
(Tabela 1).

Na Tabela 1 estão distribuídos os resultados relativos às determinações dos NMP (Número Mais Provável) de coliformes totais, termotolerantes e Pseudomonas aeroginosa por $100 \mathrm{ml}$ de água e Bactérias heterotróficas por UFC $\mathrm{mL}^{-1}$.

Tabela 1. Resultado da análise do Número Mais Provável (NMP) de coliformes totais, termotolerantes e Pseudomonas aeruginosa, e contagem de bactérias heterotróficas (UFC $\mathrm{ml}^{-1} \times 10^{3}$ ) em amostras de água para consumo humano comercializada por caminhões-pipa.

\begin{tabular}{|c|c|c|c|c|}
\hline Amostras & $\begin{array}{l}\text { Coliformes } \\
\text { Totais* }\end{array}$ & $\begin{array}{c}\text { Coliformes } \\
\text { Termotolerantes* }\end{array}$ & $\begin{array}{l}\text { Pseudomons } \\
\text { aeroginosa* }\end{array}$ & $\begin{array}{c}\text { Bactérias } \\
\text { Heterotróficas* }\end{array}$ \\
\hline $\mathrm{A}(\dot{\mathrm{m}})$ & $17 \mathrm{NMP} / 100 \mathrm{ml}$ & $9 \mathrm{NMP} / 100 \mathrm{ml}$ & $33 \mathrm{NMP} / 100 \mathrm{ml}$ & $4434 \pm 1168 \mathrm{UFC} \mathrm{ml}^{-1}$ \\
\hline $\mathrm{A}(\mathrm{T})$ & $>1600 \mathrm{NMP} 100 \mathrm{ml}$ & $90 \mathrm{NMP} / 100 \mathrm{ml}$ & $17 \mathrm{NMP} / 100 \mathrm{ml}$ & $4484 \pm 722 \mathrm{UFC} \mathrm{ml}^{-1}$ \\
\hline $\mathrm{B}(\dot{\mathrm{m}})$ & $11 \mathrm{NMP} / 100 \mathrm{ml}$ & $11 \mathrm{NMP} / 100 \mathrm{ml}$ & $11 \mathrm{NMP} / 100 \mathrm{ml}$ & $2817 \pm 471 \mathrm{UFC} \mathrm{m}^{-1}$ \\
\hline $\mathrm{B}(\mathrm{T})$ & $280 \mathrm{NMP} / 100 \mathrm{ml}$ & $17 \mathrm{NMP} / 100 \mathrm{ml}$ & $90 \mathrm{NMP} / 100 \mathrm{ml}$ & $3000 \pm 200 \mathrm{UFC} \mathrm{ml}^{-1}$ \\
\hline $\mathrm{C}(\dot{\mathrm{m}})$ & $4 \mathrm{NMP} / 100 \mathrm{ml}$ & $2 \mathrm{NMP} / 100 \mathrm{ml}$ & $11 \mathrm{NMP} / 100 \mathrm{ml}$ & $3097 \pm 453 \mathrm{UFC} \mathrm{ml}^{-1}$ \\
\hline $\mathrm{C}(\mathrm{T})$ & $9 \mathrm{NMP} / 100 \mathrm{ml}$ & $9 \mathrm{NMP} / 100 \mathrm{ml}$ & $21 \mathrm{NMP} / 100 \mathrm{ml}$ & $3600 \pm 530 \mathrm{UFC} \mathrm{ml}^{-1}$ \\
\hline $\mathrm{D}(\dot{\mathrm{m}})$ & $14 \mathrm{NMP} / 100 \mathrm{ml}$ & $12 \mathrm{NMP} / 100 \mathrm{ml}$ & $11 \mathrm{NMP} / 100 \mathrm{ml}$ & $2934 \pm 405 \mathrm{UFC} \mathrm{ml}^{-1}$ \\
\hline $\mathrm{D}(\mathrm{T})$ & $26 \mathrm{NMP} / 100 \mathrm{ml}$ & $7 \mathrm{NMP} / 100 \mathrm{ml}$ & $14 \mathrm{NMP} / 100 \mathrm{ml}$ & $3333 \pm 514 \mathrm{UFC} \mathrm{ml}^{-1}$ \\
\hline $\mathrm{E}(\dot{\mathrm{m}})$ & $<2 \mathrm{NMP} / 100 \mathrm{ml}$ & $<2 \mathrm{NMP} / 100 \mathrm{ml}$ & $<2 \mathrm{NMP} / 100 \mathrm{ml}$ & $3700 \pm 361 \mathrm{UFC} \mathrm{ml}^{-1}$ \\
\hline $\mathrm{E}(\mathrm{T})$ & 27 NMP/100ml & $90 \mathrm{NMP} / 100 \mathrm{ml}$ & $22 \mathrm{NMP} / 100 \mathrm{ml}$ & $4734 \pm 1070 \mathrm{UFC} \mathrm{ml}^{-1}$ \\
\hline
\end{tabular}

Nota: *A Portaria 2914/11MS estabelece como limites aceitáveis para coliformes totais e termotolerantes $<2 \mathrm{NMP} / 100 \mathrm{~mL}$, e para bactérias heterotróficas abaixo de $500 \mathrm{UFC} / \mathrm{mL}$. A Pseudomonas aeruginosa não é prevista por essa portaria, mesmo sendo considerada um indicador de contaminação por material orgânico. NMP - Número Mais Provável; (m) - manhã; (T) - tarde; UFC - Unidade Formadoras de Colônias.

De acordo com a Tabela 1, é possível observar que há aumento significativo na contagem microbiana das amostras coletadas na parte da tarde frente ao grupo coliforme e à espécie Pseudomonas aeruginosa, quando comparadas as análises bacteriológicas das amostras de água coletadas pela manhã (Tabela 2). Isso pode ser explicado pela influência de alguns fatores, tais como: a temperatura da água no interior do container de armazenamento, a idade da água, o material que compõem os containers dos caminhões-pipa e a reutilização dos mesmos sem uma prévia higienização. Os efeitos combinados destes fatores influenciam na abundância relativa 
de vários micro-organismos na água e, especificamente, sobre o número de bactérias totais e de patógenos oportunistas (Wang et al., 2014).

A reutilização dos containers na comercialização da água sem que seja submetido à etapas de desinfecções pode apresentar riscos do ponto de vista microbiológico, tornando-se uma possível fonte de contaminação (Carvalho, 2015). Esse fato está relacionado principalmente à ineficiência das etapas de limpeza dos containers, uma vez que o biofilme formado em seu interior não é facilmente removível (Farache Filho e Dias, 2008). Além disso, na embalagem da água mineral, rachaduras presentes na face interna podem ser locais adequados para o desenvolvimento de biofilmes e, consequentemente, a contaminação da água. Essa aderência pode explicar a longa sobrevivência deste micro-organismo, podendo sobreviver em águas envasadas por vários anos (Iwersen et al., 2009).

Tabela 2. Variação percentual (\%) dos parâmetros bacteriológicos, entre os períodos da manhã e da tarde, das amostras de água para consumo humano comercializadas por caminhões-pipa.

\begin{tabular}{ccccc}
\hline Amostras & $\begin{array}{c}\text { Coliformes } \\
\text { Totais }\end{array}$ & $\begin{array}{c}\text { Coliformes } \\
\text { Termotolerantes }\end{array}$ & $\begin{array}{c}\text { Pseudomonas } \\
\text { aeroginosa }\end{array}$ & $\begin{array}{c}\text { Bactérias } \\
\text { Heterotróficas }\end{array}$ \\
\hline A & 9312 & 900 & -48 & 4 \\
B & 2445 & 55 & 718 & 2 \\
C & 125 & 350 & 91 & -7 \\
D & 86 & -42 & 27 & 7 \\
E & 2600 & 8900 & 2100 & 32 \\
\hline
\end{tabular}

Um segundo fator que pode influenciar diretamente tanto no crescimento de micro-organismos, como no aumento da formação de biofilmes, é a temperatura, que quando elevada pode evaporar o cloro presente na água. Nesse estudo, foi observada que na parte da tarde as temperaturas encontravam-se naturalmente mais elevadas $\left(30 \pm 1^{\circ} \mathrm{C}\right)$ quando comparadas às temperaturas das amostras da mesma água coletada pela manhã $\left(20 \pm 1^{\circ} \mathrm{C}\right)$. Esses resultados foram semelhantes ao estudo realizado por Torvinen, et al. (2007) que observaram elevadas contagens microbianas com o aumento da temperatura nos sistemas de distribuição de água potável.

Outro fator a ser observado é a idade da água, ou seja, o tempo que água fica armazenada no interior dos containers dos caminhões durante a comercialização. Em um estudo realizado por Wang et al. (2014) foram observadas mudanças significativas na contagem microbiana relacionada à idade da água, o que pode ser explicado pelo efeito direto das mudanças nas condições físico-química da água durante o tempo em que fica armazenada no interior de containers de PVC. Com isso, dentre outras espécies, os autores observaram um aumento do número de Pseudomonas aeruginosa na água.

Além da temperatura e idade da água, o material do qual é composto os containers, o polietileno (PE), favorece o crescimento de micro-organismos na água, propiciando a adesão bacteriana às suas superfícies, sendo este, um dos passos iniciais para formação de biofilme. Isso agrava a contaminação da água, reduzindo a sua qualidade e aumentando a taxa de corrosão dos containers com consequente redução da segurança microbiológica através da sobrevivência de agentes patogênicos. Dentre os materiais utilizados o SS 316 e o policloreto de polivinila (PVC) foram termodinamicamente favoráveis para 6 tipos bacterianos, SS 304 para 18 tipos, e Copper, Polipropileno (PP) e Polietileno (PE) para 25 tipos de bactérias. A adesão é dependente 
da afinidade entre as propriedades físico-químicas da superfície bacteriana e dos materiais (Simões et al., 2007; Torvinen et al., 2007).

Com relação à contagem de bactérias heterotróficas, estas apresentaram um crescimento relativamente parecido nos dois horários de coleta (Tabela 2). No entanto, em ambas as coletas (manhã e tarde), essas contagens excederam o limite de 500 UFC mL-1, podendo ser consideradas impróprias para o consumo de acordo com os padrões de potabilidade estabelecidos pela portaria vigente (2914 MS/2011, Brasil, 2011), onde recomenda-se que a contagem de bactérias heterotróficas não ultrapasse o limite de $500 \mathrm{UFC} / \mathrm{mL}$.

\section{CONCLUSÃO}

A forma de comércio das águas destinadas ao consumo humano por caminhão-pipa no município de Caruaru-PE foi considerada imprópria para este fim, tendo em vista que a análise bacteriológica das mesmas apresentou baixo índice de potabilidade e um alto risco de contaminação por patógenos, fato este evidenciado pela presença dos coliformes fecais, Pseudomonas aeroginosa e pela elevada contagem de bactérias heterotróficas.

Desse modo, faz-se necessária uma fiscalização mais efetiva por parte dos órgãos responsáveis para o melhoramento dos recursos hídricos. É sugerido que seja realizado um monitoramento nos pontos de captação dos distribuidores e principalmente nos tanques que transportam a água comercializada, a fim de que haja a implantação de sistemas de controle como as Boas Práticas de Fabricação (BPF's) e as Análises de Perigos e Pontos Críticos de Controle (APPCC), garantindo que as propriedades naturais da água mineral sejam mantidas. Além disso, é fundamental a conscientização dos consumidores quanto ao seu direito em adquirir um produto de boa qualidade.

\section{AGRADECIMENTOS}

Agradecemos ao Laboratório Luiz Alberto Florêncio pelo apoio e incentivo.

\section{REFERÊNCIAS}

ALMEIDA, V. F. S.; OLIVEIRA, S. R.; JÁCOME, P. R. L. A.; JÁCOME-JÚNIOR, A. T. Avaliação de indicadores higiênico-sanitários e das características físico-químicas em águas utilizadas em escolas públicas de nível fundamental. Revista do Instituto Adolfo Lutz, v. 68, n. 3, p. 334-40, 2009.

AMERICAN PUBLIC HEALTH ASSOCIATION - APHA; AMERICAN WATER WORKS ASSOCIATON - AWWA; WATER ENVIRONMENT ASSOCIATION - WEF. Standard methods for the examination of water $\&$ wastewater. 22st edition. Washington, 2012. $1360 \mathrm{p}$.

ARAÚJO, G. F. R; TONANI, K. A. A.; RAGAZZI, M. F.; JULIÃO, F. C.; SAMPAIO, C. F.; CARDOSO, O. O. et al. Qualidade físico-química e microbiológica da água para o consumo humano e a relação com a saúde: estudo em uma comunidade rural no estado de São Paulo. O Mundo da Saúde, v. 35, n. 1, p. 98-104, 2011.

BRASIL. Ministério da Saúde. Portaria n 2914 de 12 de dezembro de 2011. Dispõe sobre os procedimentos de controle e de vigilância da qualidade da água para consumo humano e seu padrão de potabilidade. Diário Oficial [da] União, Poder Executivo, Brasília, DF, 12 mar. 2011. 
CARVALHO, A. M. Qualidade da água distribuída pelos caminhões-pipa para consumo humano. In: EXPOSIÇÃO DE EXPERIÊNCIAS MUNICIPAIS EM SANEAMENTO, 9., de 24 a 29 de maio de 2015, Poços de Caldas. Anais... Poços de Caldas: [s.n.], 2015.

CAVALCANTE, R. B. L. Ocorrência de Escherichia coli em fontes de água e pontos de consumo em uma comunidade rural. Revista Ambiente \& Agua, v. 9, n. 3, 2014. http://dx.doi.org/10.4136/ambi-agua.1301

COELHO, M. I. S.; MENDES, E. S.; CRUZ, M. C. S.; BEZERRA, S. S.; PINHEIRO, R. P. Avaliação da qualidade microbiológica de águas minerais consumidas na região metropolitana de Recife, Estado de Pernambuco. Acta Scientiarum. Health Sciences, v. 32, n. 1, p. 1-8, 2010. http://dx.doi.org/10.4025/actascihealthsci. v32i1. 3837

FARACHE FILHO, A.; DIAS, M. F. F. Qualidade microbiológica de águas minerais em galões de 20 litros. Alimentos e Nutrição Araraquara, v. 19, n. 3, p. 243-248, 2009.

INSTITUTO BRASILEIRO DE GEOGRAFIA E ESTATÍSTICA - IBGE. Estimativa da População de Caruaru no ano de 2015. Disponível em: https://goo.gl/NK9nCL https://goo.g1/NK9nCL. Acesso: 23 abril 2016

IWERSEN, A. T.; YAMANAKA, E. H. U.; LUZ JÚNIOR, L. F. D. L.; MOSNTEIRO, C. L. B.; COGO, L. L.; BEUX, M. R. Avaliação da qualidade microbiológica de águas minerais envasadas-dinâmica populacional de Pseudomonas aeruginosa. Boletim do Centro de Pesquisa de Processamento de Alimentos, v. 27, n. 2, 2009. http://dx.doi.org/10.5380/cep.v27i2.22030

MÜLLER, L. R.; PARUSSOLO, L. Qualidade microbiológica da água utilizada para consumo em escolas municipais de Mamborê, Paraná. SaBios-Revista de Saúde e Biologia, v. 9, n. 1, p. 95-99, 2014.

PEDROSA, A. P.; BRANDAO, M. L. L.; MEDEIROS, V. M.; ROSAS, C. O.; BRICIO, S. M. L; ALMEIDA, A. E. C. C; Pesquisa de fatores de virulência em Pseudomonas aeruginosa isoladas de águas minerais naturais. Revista Ambiente \& Água, v. 9, n. 2, p. 313-324, 2014. http://dx.doi.org/10.4136/ambi-agua.1359

QUATRIN, P. M.; COMIM, V. M.; LOPES, L. Q. S.; GÜNDEL, A.; ALMEIDA VAUCHER, R.; SANTOS, R. C. V. Avaliação de diferentes substratos para a formação de biofilmes in vitro de Pseudomonas aeruginosa. Disciplinarum Scientia, v. 16, n. 2, p. 191-203, 2015.

SILVA, A. F. S.; LIMA, C. A.; QUEIROZ, J. J. F.; JÁCOME, P. R. L. A.; JÁCOME-JÚNIOR, A. T. Análise bacteriológica das águas de irrigação de horticulturas. Revista Ambiente \& Água, v. 11, n. 2, 2016. http://dx.doi.org/10.4136/ambi-agua.1798

SIMÕES, L. C.; SIMÕES, M.; OLIVEIRA, R.; VIEIRA, M. J. Potential of the adhesion of bacteria isolated from drinking water to materials. Journal of Basic Microbiology, v. 47, p. 174-183, 2007. http://dx.doi.org/10.1002/jobm.200610224

TORVINEN, E.; LEHTOLA, M. J.; MARTIKAINEN, P. J.; MIETTINEN, I. T. Survival of Mycobacterium avium in Drinking Water Biofilms as Affected by Water Flow Velocity, Availability of Phosphorus, and Temperature. Applied and Environmental Microbiology, v. 73, n. 19, p. 6201-6207, 2007. http://dx.doi.org/10.1002/jobm.200610224 
WANG, H.; MASTERS, S.; EDWARDS, M. A.; FALKINHAM III, J. O.; PRUDEN, A. Effect of disinfectant, water age, and pipe materials on bacterial and eukaryotic community structure in drinking water biofilm. Environmental science \& technology, v. 48, n. 3, p. 1426-1435, 2014. http://dx.doi.org/10.1021/es402636u 


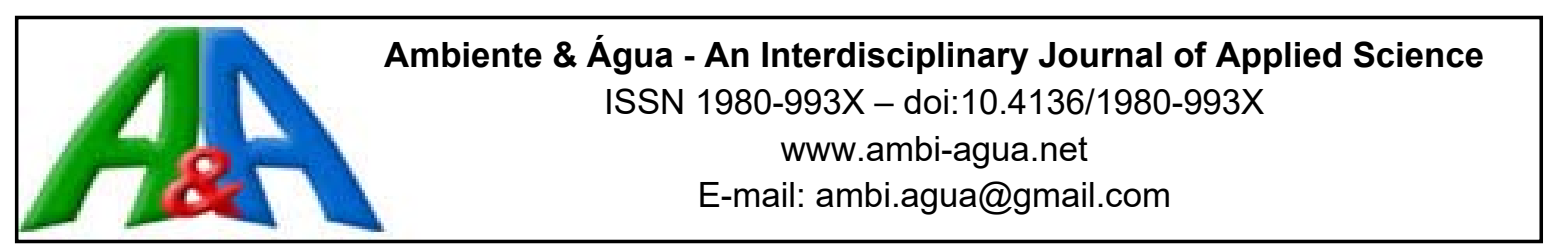

\title{
Análise hidrodinâmica do estuário do rio Lima, Portugal, a partir de simulação numérica
}

\author{
doi:10.4136/ambi-agua.1925
}

Received: 03 May 2016; Accepted: 06 Mar. 2017

\author{
Nelson Carvalho Dantas de Brito Costa ${ }^{1}$; Stênio de Sousa Venâncio ${ }^{2 *}$; \\ José Luís da Silva Pinho'; José Manuel Pereira Vieira ${ }^{1}$ \\ ${ }^{1}$ Universidade do Minho (UM), Braga, Portugal \\ Departamento de Engenharia Civil, Centro do Território, Ambiente e Construção (CTAC) \\ ${ }^{2}$ Universidade Federal do Triângulo Mineiro (UFTM), Uberaba, MG, Brasil \\ Departamento de Engenharia Civil \\ *Autor correspondente: e-mail: stenio@civil.uftm.edu.br, \\ a61843@alumni.uminho.pt,jpinho@civil.uminho.pt,jvieira@civil.uminho.pt
}

\section{RESUMO}

A complexidade que envolve a gestão sustentável das zonas costeiras, associada a sua relevância econômica e sócioambiental, tem como pré-requesito o conhecimento do padrão hidrodinâmico dos estuários, que é influenciado diretamente pelas vazões típicas e pelas marés oceânicas, como também pode sofrer impacto devido às alterações morfológicas do leito e condições de estratificação. Neste trabalho, com base no programa Delft3D, desenvolvido pela Deltares, um modelo bidimensional foi criado para a análise de padrões hidrodinâmicos do estuário do rio Lima, Portugal, a partir de simulação dos níveis da superfície livre e velocidades, considerando vazões fluviais extremas e maré alta de águas vivas. Dados de campanha hidrométrica, com monitorização da dinâmica da superfície livre do estuário, foram obtidos em quatro estações específicas e serviram para a calibração do modelo apresentando uma boa correlação entre os valores de níveis medidos e simulados, com ligeiro desvio no período de maré baixa. Pelo modelo de eficiência de Nash-Sutcliffe (NSE), por exemplo, com excessão da estação de Lanheses2 (com NSE $=0,87$ ), as outras três estações monitoradas apresentaram NSE acima de 0,94 . O modelo apresentou robustez e se mostrou capaz em representar o fenômeno real, e permite identificar o comportamento hidrodinâmico do estuário em cenários distintos de vazão e maré. As zonas suscetíveis a inundações, assim como a influência que a vazão e a maré oceânica exercem sobre o padrão hidrodinâmico, foram analisadas numericamente. Os resultados apontaram uma maior influência da vazão fluvial sobre os níveis de água no estuário, sendo que a maré exerce maior influência para o interior do estuário, principalmente em cenários de baixas vazões fluviais. O modelo pode ser considerado como uma ferramenta básica para o estudo e processo de gestão do estuário do rio Lima, cuja abrangência depende da extensão das campanhas de monitorização e calibração dos parâmetros envolvidos, que são objetivos da continuidade deste trabalho.

Palavras-chave: Delft3D, modelagem, vazão. 


\title{
Hydrodynamic analysis of Lima River estuary, Portugal, based on numerical simulations
}

\begin{abstract}
The complexity involved in the sustainable management of coastal zones, with their economic and socio-environmental importance, requires a sound knowledge of their hydrodynamics, which are directly influenced by river discharges and ocean tides, but can also be influenced by morphological changes of beds and stratification conditions. This work implemented a two-dimensional hydrodynamic model, using Delft3D software developed by Deltares for analysis of hydrodynamic patterns in the Lima River estuary, Portugal. Water levels and velocities were simulated, considering extreme river discharges and high tides of tidal waves. The model was calibrated using hydrometric field data from the measurement of water levels at four specific locations, showing a good correlation between the measured and simulated water levels, with slight deviation in the low tide period. For Nash-Sutcliffe efficiency metrics (NSE), for example, with the exception of Lanheses2 station (with NSE $=0.87$ ), the other three monitored stations showed NSE above 0.94. The model was strong and was capable of representing real phenomenon and allowing the characterization of hydrodynamic behavior in different scenarios of river discharges and tides. The areas susceptible to flooding as well as the influence the flow and ocean tides have on the hydrodynamics were numerically analyzed. The results showed a greater influence of river flow on the water levels within the estuary, with the tide exerting greater influence in the interior of the estuary, especially in low river flow scenarios. The model can be considered an important tool for the study and management of Lima River estuary, and its capabilities will be extended to morphodynamic and stratification simulations using field data that is being collected.
\end{abstract}

Keywords: Delft3D, modeling, water flow.

\section{INTRODUÇÃO}

Cerca de $60 \%$ das grandes cidades existentes no nosso planeta estão localizadas em zonas próximas a estuários, sendo estas regiões consideradas como as mais valiosas e mais apetecíveis para a população em geral (Duarte e Vieira, 1997). O elevado crescimento da ocupação humana das regiões litorais origina impactos negativos, como por exemplo as inundações. Perceber estes impactos e identificar as suas causas é uma tarefa importante e necessária para o processo de gestão sustentável, possibilitando medidas estratégicas que visem diminuir ou anular as consequências para todos os seres vivos (Bell et al., 2000). Por ora, a complexidade destes ambientes costeiros dificulta as tarefas de previsão do seu comportamento, o que se deve à interação da vazão do rio, correntes de maré e a morfologia do canal, produzindo tipos de circulação e estratificação não triviais do ponto de vista de análise, e que afetam, por sua vez, diretamente a composição e distribuição da fuana e flora. Contudo, o entendimento dos processos hidrodinâmicos e de transporte em estuários é de grande importância para o projeto de estruturas costeiras, modelagem ambiental e minimização dos efeitos de descargas poluentes.

Com o grande desenvolvimento tecnológico verificado, o domínio da hidroinformática permite simular o funcionamento destes sistemas complexos, representando um ganho monetário e de tempo consideráveis para diagnósticos e projetos, além da possibilidade de realizar prognósticos de longo prazo. Os vários modelos desenvolvidos e validados em aplicações nos sistemas hidráulicos reais de pequena e grande escala demonstram a capacidade para simular, com confiança, os processos de correntes, ondas, salinidade e de transporte de sedimentos em zonas estuarinas, como por exemplo, HAMSOM (Backhaus, 1983), POM 
(Blumberg e Mellor, 1987) e sua versão comercial ECOM-si (Blumberg, 1994), e FVCOM (Chen et al., 2003) para correntes; ECOMSED (Blumberg, 2002) para o transporte de sedimentos; SWAN (Booij et al., 1996) para agitação; o modelo ROMS (Shchepetkin e McWilliams, 2005), MIKE 3, por DHI Water and Environment, e Delft3D, por Deltares (Delft3D-Flow, 2011), instituto de pesquisa da Holanda, para simulações abrangentes. Apesar do avanço tecnológico verificado, estudos desta natureza sobrepõe as dificuldades de obtenção de dados de campo para a calibração dos modelos, sejam em escassez, escala ou até mesmo em confiança, e também as limitações matemáticas dos modelos para integrarem certos parâmetros naturais de maneira realista. Entretanto, do ponto de vista prático, as intervenções ambientais de engenharia e seus decorrentes impactos poderão ser realizados recorrendo-se à modelação matemática. Em estuários, as aplicações mais comuns advêm da previsão de inundações, análise da intrusão salina, o cálculo de tempos de residência, a propagação e rebentação das ondas e a previsão de sobrelevações e de correntes litorais devidas à agitação.

Este trabalho tem por objetivo principal caracterizar a hidrodinâmica no estuário do rio Lima, entre a sua foz em Viana do Castelo e o açude da vila de Ponte de Lima, no norte de Portugal (Figura 1), a partir de calibração hidrodinâmica de curto período dos níveis de maré, obtidos por campanhas de campo. O procedimento de calibração de níveis de água em período de tempo não extensivo tem sido apontado por diferentes trabalhos para resultados de análise hidrodinâmica realistas, como por exemplo em Hu et al. (2009), com 30 horas de calibração, Wan et al. (2014), 48 horas, e Uncles et al. (2013) com período de 48 horas, o que representa um ganho expressivo de tempo de estudo. Como objetivo específico, o conhecimento das áreas alagáveis e das zonas de baixa e elevada velocidade da água vem representar uma importância fundamental para o gerenciamento do sistema, permitindo definir políticas que sejam sustentáveis para a região do estuário. Para esta análise, valores de vazões representativos do estuário e séries temporais de maré são utilizados. O programa Delft3D utilizado neste trabalho tem sido amplamente empregado em todo o mundo (por exemplo: Harcourt-Baldwin e Diedericks, 2006; Van Maren, 2007; Bouma et al., 2007; Tonon et al., 2007; Allard et al., 2008), e pode realizar simulações de fluxos, transportes de sedimentos, ondas, qualidade da água, estudos morfológicos e processos ecológicos em áreas costeiras, fluviais e estuarinas. É constituído por vários módulos que podem interagir uns com os outros. Delft3D-FLOW, a base de um destes módulos, é um sistema multi-dimensional (2D ou 3D) hidrodinâmico (e de transporte) que resolve as equações de Navier-Stokes para um fluido incompressível sob o conceito de águas rasas e os pressupostos de Boussinesq, e calcula o transporte de sedimentos e atualizações morfológicas simultaneamente com o fluxo (ver Lesser et al., 2004, para descrição detalhada e validação). Os efeitos da agitação sobre o transporte de sedimentos também podem ser considerados por acoplamento ao módulo Delft3D-WAVE (modelo de ondas SWAN). Neste estudo, um modelo bidimensional para simulação hidrodinâmica foi desenvolvido para o estuário do rio Lima com base no Delft3D-FLOW. Após as definições de parâmetros específicos e calibração para os dados de campo obtidos, uma análise hidrodinâmica da zona estuarina foi realizada a partir da simulação dos níveis de água e velocidades para cenários de mínima e máxima vazão e maré alta de marés vivas.

\section{MATERIAL E MÉTODOS}

\section{1. Área de estudo}

Na Figura 1 é apresentada a localização da área estudada, destacando as fronteiras consideradas (montante: açude da vila de Ponte de Lima; jusante: oceano Atlântico), assim como as estações de monitorização hidrométrica utilizadas para calibrar e validar o modelo

Rev. Ambient. Água vol. 12 n. 3 Taubaté - May / Jun. 2017 
numérico (Lanheses1, Vila Mou, Lanheses2 e Cardielos). A caracterização da área segue a descrição de Pinho et al. (2014) e Vieira e Pinho (2010).

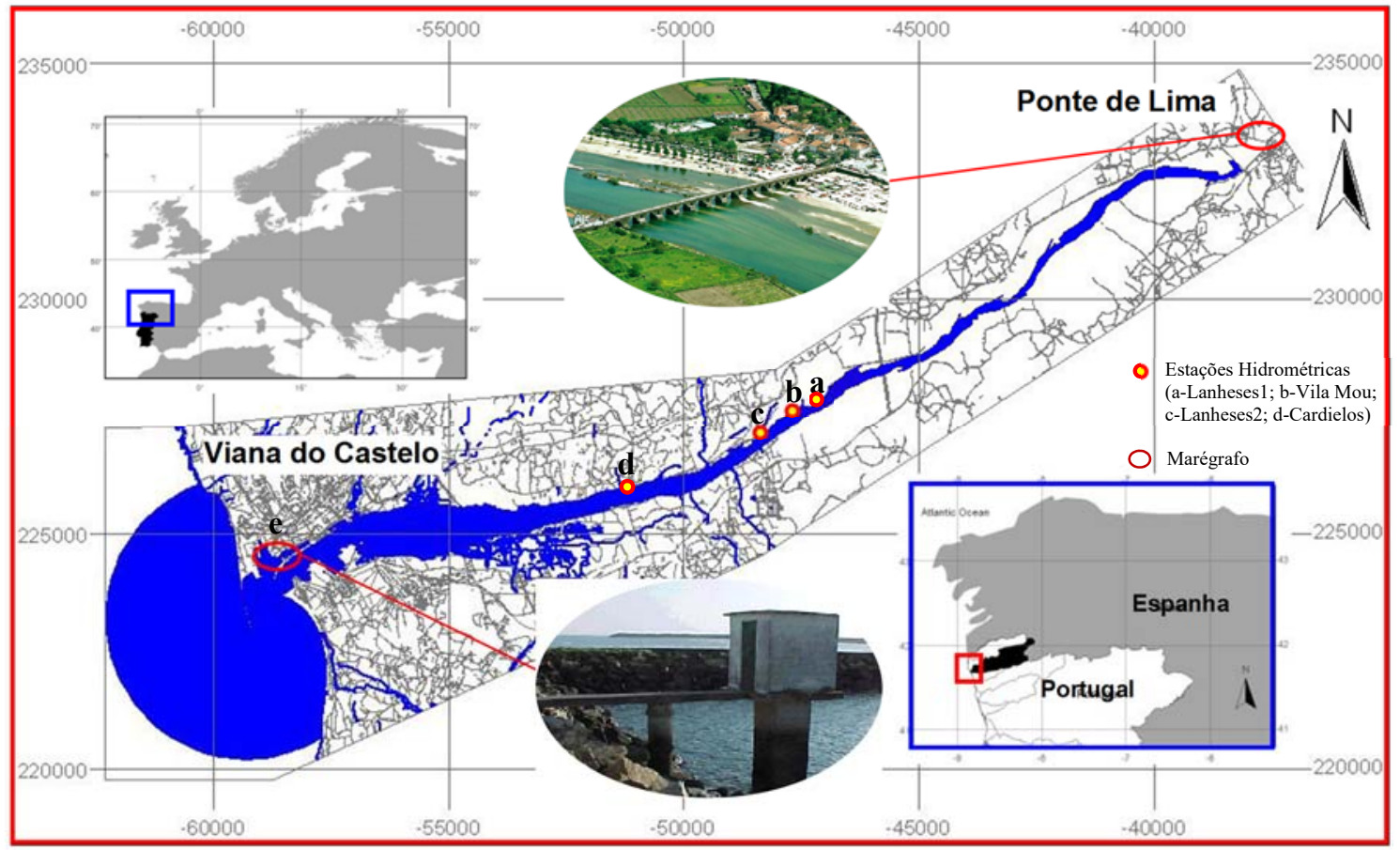

Figura 1. Localização do estuário do rio Lima, fronteiras consideradas e estações hidrométricas.

Fonte: modificado de Vieira e Pinho (2010).

O rio Lima nasce no monte Talariño, a uma altitude de 975 metros, na Serra de São Mamede, na província de Ourense em Espanha. Entra em Portugal nas proximidades de Lindoso e deságua em Viana do Castelo, apresentando uma extensão total de cerca de $108 \mathrm{~km}$, dos quais $67 \mathrm{~km}$ em território português, e destes aproximadamente $20 \mathrm{~km}$ abordados neste estudo.

A bacia do rio Lima apresenta uma forma alongada e é limitada a norte pela bacia hidrográfica do rio Minho, a leste pela do rio Douro e a sul pelas bacias dos rios Cávado e Âncora. Tem uma superfície de aproximadamente $2450 \mathrm{~km}^{2}$. A altitude média da bacia é de $447 \mathrm{~m}$, sendo a Serra da Peneda e a Serra Amarela os setores mais elevados, respectivamente com $1416 \mathrm{~m}$ e $1361 \mathrm{~m}$. O clima da região deste rio resulta da sua posição geográfica e proximidade do Atlântico e é caracterizado como sendo do tipo marítimo.

As disponibilidades hídricas desta bacia estão essencialmente dependentes da forma como a precipitação se distribui espacial e temporalmente, uma vez que os aquíferos têm uma baixa capacidade de armazenamento, o que faz com que o escoamento tenha uma resposta relativamente rápida à ocorrência de precipitação. A região desta bacia é de elevada pluviosidade, ocorrendo precipitação média anual entre 1300 e $4200 \mathrm{~mm}$.

O escoamento anual médio, quando entra em Portugal, é de $1598 \mathrm{hm}^{3}$ e na foz, de $3304 \mathrm{hm}^{3}$. De uma forma sintetizada, esta bacia apresenta um clima bastante úmido e caracteriza-se por uma pequena deficiência de água no Verão e um excesso no Inverno. A satisfação de pedidos de irrigação, de abastecimento público e para produção de energia é conseguida a partir de volumes armazenados durante períodos úmidos. São dois os grandes aproveitamentos hidroelétricos em funcionamento ao longo da bacia: Alto Lindoso e Touvedo. A barragem do Alto Lindoso situa-se junto da fronteira com a Espanha, sendo o maior produtor hidroelétrico de Portugal. Funciona como reguladora da vazão do rio Lima em conjunto com a barragem de Touvedo, estando ambas as barragens à montante do trecho do estuário estudado. 
No estuário, o rio fica mais largo e com uma inclinação muito reduzida, propiciando a formação de depósitos sedimentares tanto no leito como nas suas margens. Assim, formam-se ínsuas e margens muito extensas, que rapidamente são dominadas por vegetação herbácea, criando uma série de praias fluviais até à zona de Viana do Castelo. Devido a estas características, as zonas de leito de cheia do rio são zonas com uma cota muito próxima das margens e com uma grande extensão que, na ocorrência de grandes vazões, são facilmente inundadas, chegando a aumentar em duas vezes a largura do rio. No que diz respeito à zona da foz em Viana do Castelo, esta varia de 800 m, perto da ponte Eiffel, até 300 m, entre o porto antigo e o novo. Existe esta variação de larguras devido à presença do porto marítimo de maiores dimensões para conseguir dar resposta a maiores embarcações. Assim, o porto passou da margem norte para a margem sul, estreitando ainda mais o rio. Consequentemente, e com a necessidade de garantir a entrada e saída das embarcações, existem duas obras marítimas de grandes dimensões que protegem a entrada da foz das fortes ondulações provenientes do mar. Neste percurso o canal do rio é estreito e possui uma profundidade média de $10 \mathrm{~m}$, havendo uma sistemática remoção de inertes por parte do porto de Viana do Castelo para manter as condições de navegabilidade do canal. De acordo com o estudo feito pela empresa de projetos de engenharia PROMAN (2006), na zona do estuário não existem afluentes com dimensão nem vazão suficientes para provocar alterações significativas no canal principal do rio. Em relação às vazões existentes no Rio Lima, estas são diretamente condicionadas e geradas pelas duas barragens referidas. Segundo análises estatísticas dos dados existentes na plataforma do Sistema Nacional de Informação de Recursos Hídricos (SNIRH), da estação hidrométrica que existe $\operatorname{logo}$ a seguir à barragem de Touvedo, conclui-se que a vazão média anual ronda os $38 \mathrm{~m}^{3} / \mathrm{s}$. Porém, em época de verão, este valor pode baixar para cerca de $5 \mathrm{~m}^{3} / \mathrm{s}$.

\subsection{Dados de campo}

O trabalho de campo foi realizado entre o dia 06-07-2015 e o dia 11-07-2015 e consistiu da colocação de sonda do tipo RBR- TGR2050 nos locais já identificados anteriormente na Figura 1. A escolha dos locais se deu em função da facilidade de acesso e atendimento aos critérios necessários para a instalação do equipamento, além do critério hidráulico (Figura 2a). De posse dos dados de previsão de maré para o período através do Instituto Hidrográfico, foi instalada a sonda no período de maré baixa o que, além de facilitar a instalação, possibilita registrar um maior conjunto temporal de níveis de água com a sonda submersa. A sonda foi fixada, através das estruturas existentes, ex. estrutura de ancoragem de barcos (Figura 2b), ou usando a estrutura metálica própria (Figura 2c). Após o processo de instalação, a mesma foi coberta com vegetação de forma a garantir a sua segurança, previnindo contra possíveis danos ou furto (Figura 2d). O equipamento ficou submerso durante dois períodos de maré ( 24 horas) para as estações de Lanheses 1, Lanheses 2 e Vila Mou. Na estação de Cardielos só foi conseguido um período de maré (12 horas) devido às questões operacional e de segurança, pois esta foi instalada em um local com característica balnear (de fácil acesso). Os dados registrados pela sonda, em cada ciclo da campanha, foram exportados para o programa Excel através do software Ruskin do próprio equipamento, sendo a sonda reconfigurada para o próximo ciclo. Adicionalmente à campanha de registro de níveis de água no estuário, foi obtido também o registro instantâneo de maré oceânica pelo marégrafo de Viana do Castelo, assim como as vazões diárias típicas, máxima e mínima do estuário através dos dados fornecidos pela companhia Energias de Portugal - EDP. Os dados de vazão foram gerados a partir do complexo hidrelétrico de Touvedo. Os dados de batimetria do estuário são relativos ao final do ano de 2003 e início de 2004, e foram obtidos pela APA - Agência Portuguesa do Ambiente, sendo que na área específica da foz (na embocadura), refere-se ao levantamento feito pela Administração do Porto de Viana do Castelo, para o mesmo período.

Rev. Ambient. Água vol. 12 n. 3 Taubaté - May / Jun. 2017 


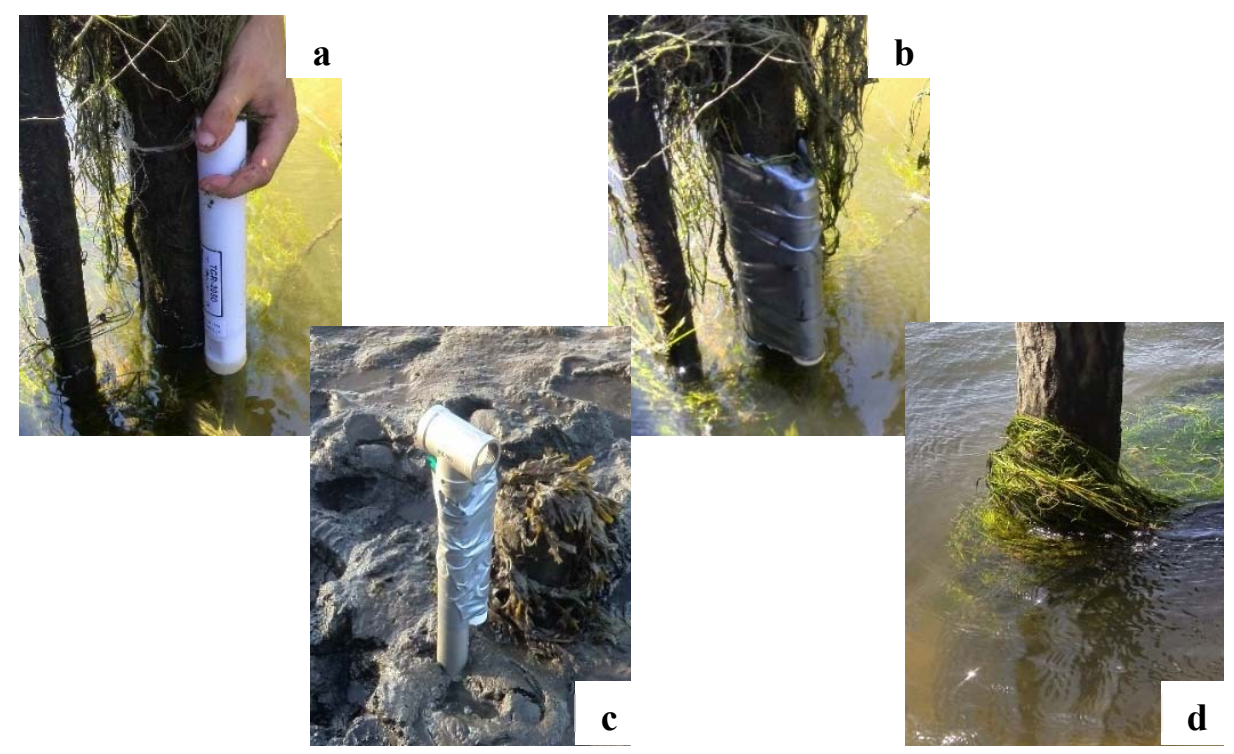

Figura 2. Processo de instalação da sonda para o registro dos níveis de água (Cardielos).

\subsection{Simulação numérica}

A escolha do módulo 2D do código Delft3D adequa-se aos objetivos do trabalho onde a determinação do leito de cheia é pretendido. Testes realizados por este trabalho envolvendo também o módulo 3D conduziram para resultados semelhantes aos obtidos no módulo 2D, mas com tempo de processamento maior. $\mathrm{O}$ modelo numérico hidrodinâmico bidimensional construído com o uso do módulo FLOW do Delft3D (Delft3D-FLOW, 2011) resolve numericamente as equações de conservação de massa e quantidade de movimento obtidas a partir das equações de Navier_Stockes, recorrendo a um método numérico baseado no método das diferenças finitas. Assume-se o conceito de águas rasas para a determinação dos níveis de água e velocidades. Sua implementação consistiu, inicialmente, da elaboração de uma malha computacional, com um total de 15558 células de cálculo ortogonais, e respectiva batimetria (Figura 3), com dimensões variando entre $10 \mathrm{~m}$ e $500 \mathrm{~m}$, necessárias e suficientes para abranger toda a área do estuário (leitos maior e menor). Os dados batimétricos do estuário foram disponibilizados pela Administração do Porto de Viana do Castelo. De maneira a evitar instabilidades numéricas, o passo de tempo definido foi de 1 minuto, sendo que valores superiores conduziram para a instabilidade do processamento. Os parâmetros de resistência e de turbulência adotados decorreram dos processos de calibração dos níveis de água (dados de campo) e testes de sensibilidade, assumindo o coeficiente de rugosidade de Manning o valor de $0,015 \mathrm{~s} . \mathrm{m}^{-1 / 3}$ e o coeficiente de viscosidade e difusividade turbulenta horizontal de $1 \mathrm{~m}^{2} / \mathrm{s}$. Nas fronteiras abertas do modelo numérico foram considerados a vazão média diária (à montante) e os dados de maré instantânea (à jusante), relativos ao período da campanha. Os pontos de monitoramento de nível de água no estuário foram, conforme campanha, introduzidos na malha numérica para a calibração do modelo (cenário $\mathrm{C} 1$ ). O período simulado pelo modelo, para o cenário $\mathrm{C} 1$, é de 7 dias, sendo o mesmo calibrado para os dados de níveis de maré de 24 horas, registrados pela sonda. Para a análise numérica dos níveis hidrodinâmicos, várias configurações de vazão e maré foram avaliadas após a calibração do modelo. Dois cenários representativos foram propostos: a situação das cheias no estuário e também o perfil de vazão fluvial baixa. A vazão mínima considerada, $38 \mathrm{~m}^{3} / \mathrm{s}$ (cenário $\mathrm{C} 2$ ), que é registrada ou é superada durante $50 \%$ do tempo, propicia uma avaliação da influência da maré nos níveis de água do estuário; já a vazão máxima de $3200 \mathrm{~m}^{3} / \mathrm{s}$ (cenário C3), corresponde a vazão milenar e permite identificar o efeito da vazão sobre os níveis de água atingidos no estuário. Ambos os cenários consideram 
maré alta em situação de marés vivas. O período de simulação é de 2 dias para $\mathrm{C} 2$ e C3, tempo suficiente para o estabelecimento das condições de máximos níveis no estuário. Apesar do modelo permitir a inserção da variável vento no processo de cálculo hidrodinâmico, o mesmo não foi considerado. Isto porque a dimensão máxima do escoamento em relação às características do vento faz com que estas últimas assumam correntes de ordem inferior, como verificado em testes preliminares e conforme também concluído por Vieira e Pinho (2010), não interferindo nos resultados gerados pelo modelo.

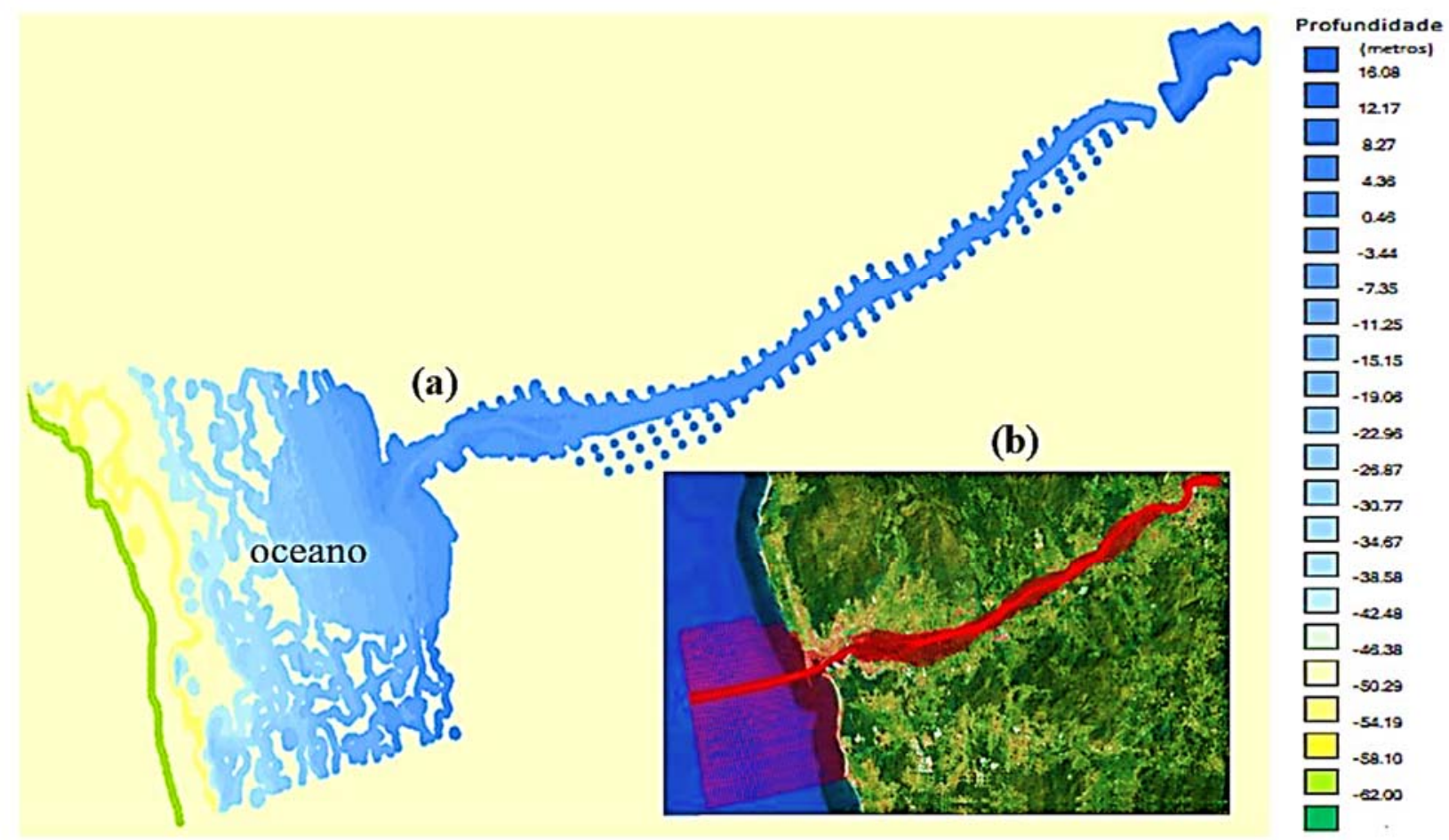

Figura 3. Batimetria (a) e malha computacional (b) utilizadas no modelo numérico.

\section{RESULTADOS E DISCUSSÃO}

Para o cenário de calibração $(\mathrm{C} 1)$, os resultados do modelo apresentaram uma boa concordância, segundo análise gráfica e quatro métricas utilizadas: o modelo de eficiência de Nash-Sutcliffe (NSE), a soma das diferenças entre valores simulados e valores observados (BIAS), raiz quadrada do erro quadrático médio (RMSE) e a média do erro absoluto (MAE). A Figura 4 mostra o gráfico de calibração com os valores obtidos pelas métricas.

A resposta apresentada pelo modelo demonstra robustez, com capacidade de representar o fenômeno real. Pelo modelo de eficiência de Nash-Sutcliffe (NSE), por exemplo, com exceção da estação de Lanheses2 (com NSE $=0,87$ ), todas as outras estações apresentaram NSE acima de 0,94. Ligeiras diferenças entre níveis medidos e simulados apenas foram verificadas nas estações de Lanheses 1 e Lanheses 2 no período de maré baixa, e podem estar associadas à leitura feita pela sonda nestas condições ou devido ao próprio modelo de elevação utilizado como base da simulação hidrodinâmica, que causa impacto direto, sobretudo em cenários de maré baixa, conforme destacado por Falcão et al. (2013). Entretanto, dada à aproximação conseguida, é de considerar que este fato não compromete a análise da característica hidrodinâmica do estuário. Como é de se observar também, os registros de níveis mínimos efetuados pela sonda ficaram prejudicados para a situação de maré baixa. Isto ocorreu devido à cota de instalação da sonda 
por limitações físicas locais (ex.: base de fixação, vegetação, assoreamento), mas que não compromete a análise qualitativa proposta para este trabalho.

$\mathrm{O}$ resultados das simulações referentes aos níveis de água obtidos no estuário para os cenários C2 e C3 são apresentados na Figura 5.

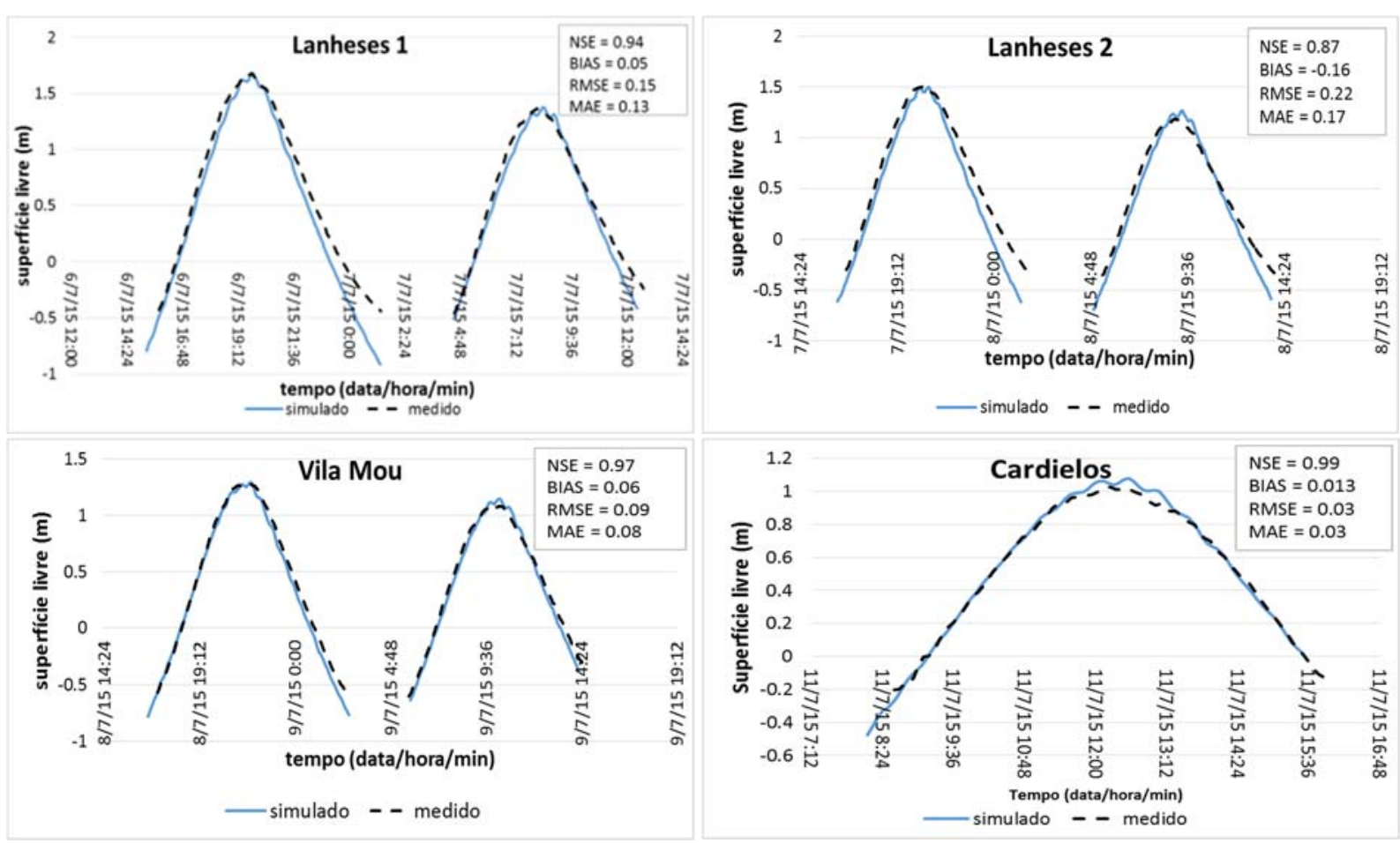

Figura 4. Calibração dos níveis de água, cenário $\mathrm{C} 1$, com coeficiente de rugosidade de Manning de $0.015 \mathrm{~s} . \mathrm{m}^{-1 / 3} \mathrm{e}$ viscosidade turbulenta de $1 \mathrm{~m}^{2} / \mathrm{s}$.

Uma análise comparativa entre os dois cenários mostrados possibilita verificar uma ampliação considerável na largura do leito de escoamento de $\mathrm{C} 2$ para $\mathrm{C} 3$, o que denota uma influência considerável da vazão de Touvedo sobre o estuário, uma vez que ambos os cenários foram simulados sob a mesma condição de maré. Dada a característica topográfica do leito do estuário e das áreas adjacentes, uma elevação considerável do nível de água não é verificada, o que vem a justificar a ampliação da seção transversal do leito de escoamento. As profundidades de água registradas pelo modelo no cenário $\mathrm{C} 2$ variam entre os $4 \mathrm{~m}$ à $10 \mathrm{~m}$, com exceção da foz do estuário, onde o valor de $10 \mathrm{~m}$ é superado. Estes níveis se aproximam dos valores reais em pontos amostrados no trecho central do estuário, para vazões próximas da considerada no cenário C2. As áreas de inundação identificadas pelo modelo numérico no cenário C3 são condizentes às marcas de inventário relativas à cheia de 15/11/1987, que registrou vazão fluvial de $3120 \mathrm{~m}^{3} / \mathrm{s}$ e nível de água de 7,25 m no açude da vila de Ponte de Lima (Pinho et. al., 2014), com impacto direto para os vários núcleos populacionais instalados nestas áreas, e que exercem atividade agrícola fixada nos leitos de cheia. Também é destacada na Figura 5, cenário C3, a isóbara de cheia correspondente ao estudo realizado pela Agência Portuguesa do Ambiente - APA, na hipótese de baixo risco de inundação (vazão milenar) para a região de Ponte de Lima, cuja área inundada é praticamente idêntica à gerada pelo modelo numérico. Este estudo é disponibilizado pelo Sistema Nacional de Informação de Ambiente (SNIAmb, 2016) e tem como referência a Directiva 2007/60/CE do Parlamento Europeu e do Conselho de 23 de outubro de 2007, relativa a avaliação e gestão dos riscos de inundações. 


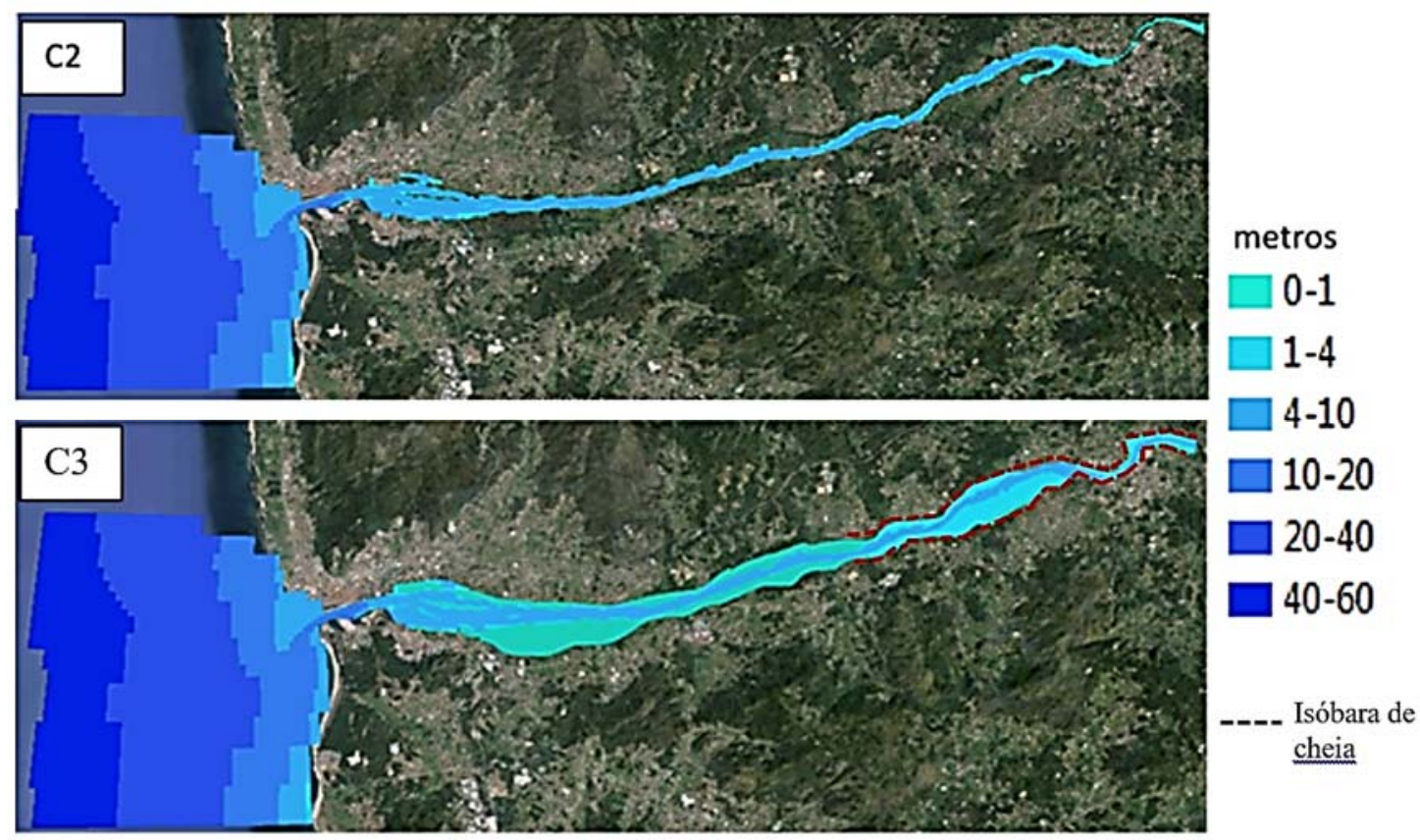

Figura 5. Nível de água no estuário, referido ao NMmar, em situação de maré viva, para os cenários C2 $\left(38 \mathrm{~m}^{3} / \mathrm{s}\right)$ e C3 $\left(3200 \mathrm{~m}^{3} / \mathrm{s}\right)$, com isóbara de cheia (SNIAmb, 2016).

Na Figura 6 apresentada a seguir são destacados três pontos no modelo numérico do estuário (A - embocadura, B - zona central da foz e C - início da foz), onde é feita uma análise das velocidades obtidas na simulação de forma a complementar a caracterização hidrodinâmica pretendida. Nota-se que a zona imediatamente anterior à foz (especificamente em C) possui velocidades baixas não superiores a $1.6 \mathrm{~m} / \mathrm{s}$, o que indica que nestas zonas há a forte possibilidade de ocorrer depósitos de sedimentos, mesmo em situação de valores elevados de vazão. Esta realidade é constatada in loco pelos depósitos de sedimentos configurados nesta zona do estuário. No ano de 2014, foram gastos meio milhão de euros em dragagens na região próxima da foz para manter o canal navegável (Barbosa, 2015).

É observado também nos gráficos da Figura 6, que para o cenário C2 existem picos de velocidade consecutivos de pequena amplitude, em conformidade com a oscilação entre maré alta e maré baixa. Entretanto, para o cenário C3, os picos são de maior amplitude e com valores de velocidade também maiores. Este fato sugere, para a vazão de cheia milenar, um predomínio do escoamento de montante para o cenário C3 durante toda a simulação. Contudo, há uma tendência mínima de inversão do escoamento para este mesmo cenário nas regiões $(A)$ e (B), que decorrem da influência dos picos de maré. Para o cenário $\mathrm{C} 2$, a tendência de inversão do sentido de escoamento de jusante para montante, é também sentida na região $\mathrm{C}$, cuja propagação foi verificada por quase $20 \mathrm{~km}$ a partir da foz. No estudo realizado por Rebordão e TrigoTeixeira (2009) aplicando o modelo hidrodinâmico ADCIRC para o mesmo estuário, foi verificada uma propagação da maré oceânica para a montante com valor idêntico, considerando a situação de marés vivas e mortas e vazões fluviais. Este fato, considerando o histórico de baixos valores de vazão no estuário, cuja intensidade é controlada pelos reservatórios de montante, justifica a potencialidade da região da foz por exemplo para depositar sedimentos no leito. As pequenas instabilidades registradas nos gráficos de velocidade, sobretudo na zona da foz, são decorrentes da conformação geométrica das células, com característica ortogonal. 

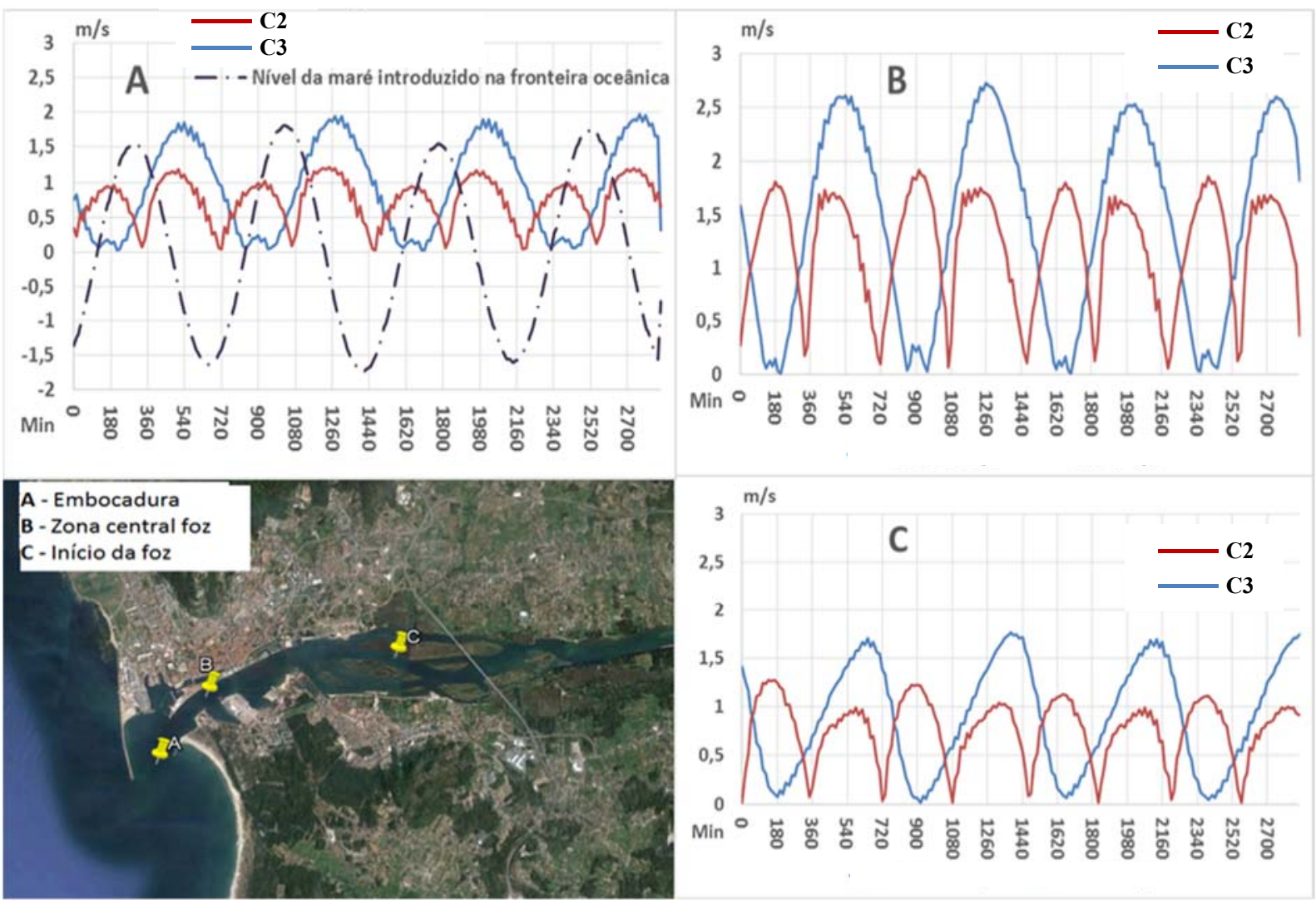

Figura 6. Velocidades simuladas em três pontos distintos da foz de Viana do Castelo, para os cenários $\mathrm{C} 2\left(38 \mathrm{~m}^{3} / \mathrm{s}\right)$ e $\mathrm{C} 3\left(3200 \mathrm{~m}^{3} / \mathrm{s}\right)$.

\section{CONCLUSÕES}

Atendendo a demanda prática do gestor do sistema de se conhecer a dinâmica hidráulica do estuário do rio Lima, um estudo inicial foi proposto. Campanha de monitoramento de nível em pontos do estuário foi realizada e um modelo numérico bidimensional foi implementado.

Os resultados de calibração obtidos permitiram extrapolar à análise numérica para dois cenários distintos, vazão mínima e cheia milenar. A vazão de Touvedo é determinante para a configuração dos níveis de água no estuário, tendo a maré oceânica uma influência restrita a foz de Viana do Castelo em cenário de cheia. Os valores de velocidade no estuário são relativamente baixos mesmo em situações de cheia, justificados pela presença de planícies de inundação ao longo do mesmo. Este fato condiciona a uma ampliação considerável do leito de escoamento em situações de cheia, fato este comprovado pelos inventários do estuário, o que vem a afetar a população ribeirinha para fins econômicos, de segurança e de lazer, além de potencializar o assoreamento identificado in loco principalmente junto da foz.

Do ponto de vista de simulação numérica, o modelo apresentou robustez e capacidade de bem representar a hidrodinâmica do estuário. Com base no conjunto de dados reunidos retrata, e com boa aproximação, a zona de inundação prevista para o entorno da vila de Ponte de Lima, segundo marcas da cheia ocorrida em novembro de 1987 e também ao estudo da Agência Portuguesa do Ambiente. Entretanto, para um avanço nas análises quantitativas, uma extensão de campanhas de campo é sugerida, de forma a possibilitar, inclusive, a análise numérica para a questão morfodinâmica, que também se apresenta como demanda dos gestores do sistema. Já com relação à campanha de níveis de água realizada, recomenda-se uma recalibração da sonda para as estações hidrométricas de Lanheses1 e Laneses2, para a situação de maré baixa, onde foi detectada ligeira divergência entre os valores medidos e simulados. Uma estratégia de 
instalação das sondas em cotas mais profundas do estuário também deverá ser analisada, com o intuito de contemplar os níveis de água correspondentes a maré baixa.

Finalmente, este estudo permitiu esboçar o padrão do comportamento hidrodinâmico do estuário do rio Lima para situações de maré e vazão fluvial extremas. Este fato, por sua vez, viabiliza tomadas de decisão realistas, como por exemplo, no subsídio da implementação de sistemas de alerta de inundação e ações da Defesa Civil na gestão do armazenamento de água e descargas de Touvedo, na definição da extensão das zonas de dragagem e também dos pontos de monitoramento hidráulico e sedimentométrico para campanhas periódicas pretendidas na continuidade deste trabalho. Por ora, um importante passo foi dado, possibilitando um maior conhecimento sobre a hidrodinâmica do estuário e, por conseguinte, permitindo o estabelecimento de políticas de gestão que resultem em ações e medidas não tomadas sem o necessário conhecimento como tradicionalmente acontece em grande parte destes sistemas hidráulicos complexos.

\section{AGRADECIMENTOS}

Os autores agradecem ao CNPq pela bolsa (Processo 200016/2014-8) de pós-doutoramento concedida ao autor 2.

\section{REFERENCIAS}

ALLARD, R.; DYKES, J.; HSU, Y. L.; KAIHATU, J.; CONLEY, D. A real-time nearshore wave and current prediction system. Journal Marine System, v. 69, p. 37-58, 2008. http://dx.doi.org/10.1016/j.jmarsys.2007.02.020

BACKHAUS, J.O. A semi-implicit scheme for the shallow water equations for application to shelf sea modeling. Continental Shelf Research, v. 2, p. 243-254, 1983. http://dx.doi.org/10.1016/0278-4343(82)90020-6

BARBOSA, B. Um milhão para dragagens. Aurora do Lima, n. 4, 2015.

BELL, R.; GREEN, M.; HUME, T.; GORMAN, R. What regulates sedimentation in estuaries? Water and Atmosphere, v. 8, p. 13-16, 2000.

BOOIJ, N.; HOLTHUIJSEN, L. H.; RIS, R. C. The SWAN wave model for shallow water. In: INTERNATIONAL. CONFERENCE ON COASTAL ENGINEERING, 25., 1996, Orlando. Proceedings... New York: ASCE, 1996. vol. 1. p. 668-676.

BOUMA, T. J.; VAN DUREN, L. A.; TEMMERMAN, S.; CLAVERIE, T.; BLANCOGARCIA, A.; YSEBAERT, T. et al. Spatial flow and sedimentation patterns within patches of epibenthic structures: combining field, flume and modelling experiments. $\begin{array}{llllll}\text { Continental Shelf Research, } 2007 . & \text { v. 27, p. 1020-1045, }\end{array}$ http://dx.doi.org/10.1016/j.csr.2005.12.019

BLUMBERG, A. F.; MELlOR, G. L. A description of a three-dimensional coastal ocean circulation model. In: HEAPS, N. S. (Ed.). Three-Dimensional coastal ocean models. Washington, DC: American Geophysical Union, 1987. p. 1-16. http://dx.doi.org/10.1029/CO004p0001

BLUMBERG A.F. A primer for ECOM-si. Technical report of HydroQual, 66 p., 1994.

BLUMBERG, A.F. A primer for Ecomsed. Technical report of HydroQual, 188 p., 2002. 
CHEN, C.; LIU, H.; BEARDSLEY, R. C. An unstructured, finite volume, threedimensional, primitive equation ocean model: application to coastal ocean and estuaries. Journal of Atmospheric and Oceanic Technology, v. 20, p. 159-186, 2003.

DELFT3D-FLOW. User Manual: simulation of multi-dimensional hydrodynamic flows and transport phenomena, including sediments. Deltares, 2011. $674 \mathrm{p}$.

DUARTE, A.; VIEIRA, J. Caracterização dos ambientes estuarinos: mistura em estuários. Braga: Universidade do Minho, 1997.

FALCÃO, A. P.; MAZZOLARI, A.; GONÇALVES, A. B.; ARAÚJO, M. A. V. C.; TRIGOTEIXEIRA, A. Influence of elevation modelling on hydrodynamic simulations of a tidally-dominated estuary. Journal of Hydrology, v. 497, p. 152-164, 2013. http://dx.doi.org/10.1016/j.jhydrol.2013.05.045

HARCOURT-BALDWIN, J. L.; DIEDERICKS, G. P.; J. Numerical modelling and analysis of temperature controlled density currents in Tomales Bay, California. Estuarine Coastal Shelf Science, v. 66, p. 417-428, 2006. http://dx.doi.org/10.1016/j.ecss.2005.10.001

HU, K.; DING, P.; WANG, Z.; YANG, S. A 2D/3D hydrodynamic and sediment transport model for the Yangtze Estuary, China. Journal of Marine Systems, v. 77, p. 114-136, 2009. http://dx.doi.org/10.1016/j.jmarsys.2008.11.014

LESSER, G. R.; ROELVINK, J. A.; VAN KESTER, J. A. T. M.; STELlinG, G. S. Development and validation of a three-dimensional morphological model. Coastal Engineering, v. 51, p. 883-915, 2004.

http://dx.doi.org/10.1016/j.coastaleng.2004.07.014

PINHO, J. L. S.; FERREIRA, R.; VIEIRA, L.; SCHWANENBERG, D. Comparison between two hydrodynamic models for flooding simulations at river Lima basin. Water Resource Management, v. 29, n. 2, p. 431-444, 2014. http://dx.doi.org/10.1007/s11269-014-08786

PROMAN - CENTRO DE ESTUDOS E PROJECTOS SA. Projeto das obras de $\mathbf{1}^{\mathbf{o}}$ fase de expansão portuária do porto de Viana do Castelo. Lisboa, 2006.

REBORDÃO, I.; TRIGO-TEIXEIRA, A. Tidal propagation in the Lima estuary. Journal of Coastal Research, SI-56, p. 1400-1404, 2009. http://www.jstor.org/stable/25738019

SHCHEPETKIN, A. F.; McWILliAMS, J. C. The Regional Ocean Modeling System: a splitexplicit, free-surface, topography following coordinates ocean model. Ocean Modelling Journal, v. 9, p. 347-404, 2005. http://dx.doi.org/10.1016/j.ocemod.2004.08.002

SISTEMA NACIONAL DE INFORMAÇÃO DE AMBIENTE - SNIAMB (Portugal). Website. Disponível em: http://sniamb.apambiente.pt/Home/Default.htm. Acesso em: 10 nov. 2016.

TONNON, P. K.; VAN RIJN, L. C.; WALSTRA, D. J. R. The morphodynamic modelling of tidal sandwaves on the shoreface. Coastal Engineering Journal, v. 54, p. 279-296, 2007. http://dx.doi.org/10.1016/j.coastaleng.2006.08.005

UNCLES, R. J.; STEPHENS, J. A.; HARRIS, C. Towards predicting the influence of freshwater abstractions on the hydrodynamics and sediment transport of a small, strongly tidal estuary: The Devonshire Avon. Ocean \& Coastal Management, v. 79, p. 83-96, 2013. http://dx.doi.org/10.1016/j.ocecoaman.2012.05.006 
VAN MAREN, D. S. Grain size and sediment concentration effects on channel patterns of siltladen rivers. Sedimentary Geology Journal, v. 202, p. 297-316, 2007. http://dx.doi.org/10.1016/j.sedgeo.2007.04.001

VIEIRA, J. M. P.; PINHO, J. L. S. Distribuição salina na embocadura e estuário do rio Lima em diferentes regimes hidrodinâmicos. Revista Recursos Hídricos, v. 31, n. 2, p. 5-14, 2010 .

WAN, Y.; GU, F.; WU, H.; ROELVINK, D. Hydrodynamic evolutions at the Yangtze Estuary from 1998 to 2009. Applied Ocean Research, v. 47, p. 291-302, 2014. http://dx.doi.org/10.1016/j.apor.2014.06.009 


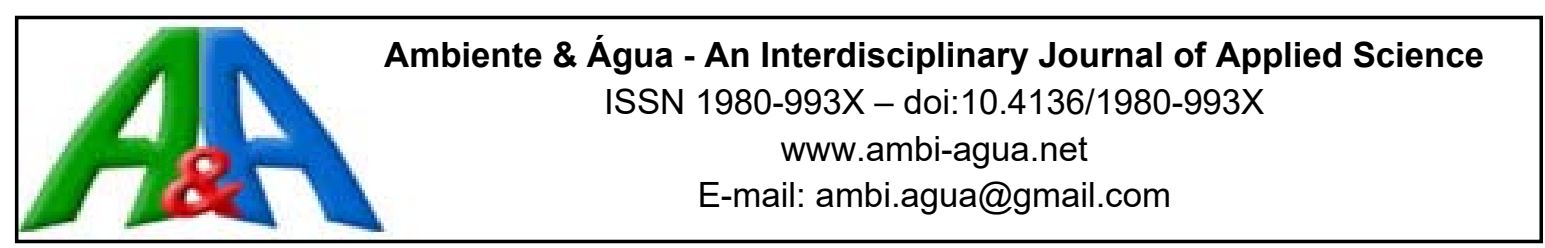

\title{
Variabilidade de concentração de metano na região do Pantanal Mato- grossense usando dados do satélite AQUA
}

\author{
doi:10.4136/ambi-agua.1985
}

Received: 16 Aug. 2016; Accepted: 03 Feb. 2017

\author{
Tonny Jader de Moraes*; Fernando da Silva Sallo; Carlo Ralph de Musis; \\ Luciana Sanches; Iramaia Jorge Cabral de Paulo; Rafael da Silva Palácios
Universidade Federal de Mato Grosso (UFMT) / Instituto de Física (IF), Cuiabá, MT, Brasil
Programa de Pós-Graduação em Física Ambiental
*Autor correspondente: e-mail: tonny@fisica.ufmt.br, fdss88@gmail.com, carlo.demusis@gmail.com, lsanches@hotmail.com, iramaiaj@gmail.com, rafael.pgfa@gmail.com

\section{RESUMO}

A emissão de metano é um fator importante na gestão de áreas alagadas como o Pantanal. Zonas úmidas em todo o mundo contribuem para o ciclo global do $\mathrm{CH}_{4}$, emitindo cerca de um terço do $\mathrm{CH}_{4}$ global. No entanto, a dinâmica de $\mathrm{CH}_{4}$ na atmosfera acima do Pantanal, continua mal compreendida. Neste trabalho estudou-se a variabilidade de $\mathrm{CH}_{4}$ na atmosfera na região do Pantanal com base na série temporal de concentração de $\mathrm{CH}_{4}$ (2003-2013), a partir de dados do sensor AIRS a bordo do satélite AQUA, e se analisou sua relação com a precipitação. A metodologia utilizada baseou-se em estatísticas descritivas que incluem médias semanais, anomalias baseadas na variância, correlação cruzada entre precipitação e concentração de $\mathrm{CH}_{4}$, e transformada wavelet. Os resultados mostraram que existe uma concentração média sazonal e a variabilidade da anormalidade de $\mathrm{CH}_{4}$ com uma precipitação é negativa. Variações sub-anuais de $\mathrm{CH}_{4}$ foram inversamente proporcionais às de precipitação, devido possivelmente ao aumento da concentração de hidroxila [OH-] durante a estação chuvosa, o que diminui o saldo de emissão de $\mathrm{CH}_{4}$. A análise wavelet permitiu observar um ciclo anual e interanual da concentração de $\mathrm{CH}_{4}$ entre 2009 a 2013.

Palavras-chave: correlação cruzada, precipitação, wavelet.

\section{Methane concentration variability in Pantanal region in the Mato Grosso State using data from AQUA satellite}

\begin{abstract}
Methane emission is an important factor in the management of wet areas such as the Pantanal region. The temporal variability of $\mathrm{CH}_{4}$ concentrations on the Pantanal was therefore studied using remote sensing data from 2003 to 2013 from an AIRS sensor on board of AQUA satellite. Wetlands worldwide contribute to the overall $\mathrm{CH}_{4}$ cycle, emitting around one-third of the overall $\mathrm{CH}_{4}$. However, the dynamics of $\mathrm{CH}_{4}$ remain poorly understood in the Pantanal. This work studied the variability of $\mathrm{CH}_{4}$ in the atmosphere over the Pantanal of Mato Grosso, based on the time series of $\mathrm{CH}_{4}$ concentration (2002-2013). The methodology used was based on descriptive statistics that included weekly averages, variance anomalies, cross-correlation between precipitation and concentration of $\mathrm{CH}_{4}$, and the transformed wavelet technique. The
\end{abstract}


results showed a seasonal average concentration and the variability of $\mathrm{CH}_{4}$ abnormality in a negative cross-correlation with precipitation. Sub-annual variations of $\mathrm{CH}_{4}$ were inversely related to precipitation, and seemed to be influenced by the concentration of hydroxyl [OH-] during the rainy season, which reduces the balance of $\mathrm{CH}_{4}$ emissions. The wavelet analysis found an annual and inter-annual cycle of $\mathrm{CH}_{4}$ concentration between 2009-2013.

Keywords: cross-correlation, rainfall, wavelet.

\section{INTRODUÇÃO}

$\mathrm{O}$ metano $\left(\mathrm{CH}_{4}\right)$ é o composto químico orgânico mais abundante da atmosfera. Vários estudos indicam que sua concentração vem aumentando de aproximadamente 722 ppb em 1750, para $1802 \pm 1 \mathrm{ppb}$ (Dlugokencky et al., 2011) atingindo mais que o dobro desde o período pré-industrial (Bousquet et al., 2006). As áreas alagáveis são importantes por serem sensíveis as modificações climáticas e são os maiores emissores naturais de $\mathrm{CH}_{4}$, sendo que o seu aumento pode atuar como uma retroalimentação positiva para o aquecimento futuro (Melton et al., 2013).

As áreas alagáveis são a maior fonte natural de $\mathrm{CH}_{4}$ na atmosfera, contribuindo $145 \mathrm{Tg}$ ano $^{-1}$, o que corresponde a cerca de $24 \%$ da emissão total de todas as fontes, e são especialmente importantes durante o período das chuvas (Bousquet et al., 2011). No Brasil há um alagamento sazonal em grandes áreas como a região Amazônica e o Pantanal. A inundação sazonal do Pantanal traz um conjunto de características distintas em suas dinâmicas de nutrientes e pulso de inundação (Vourlitis et al., 2013). Nessa área a vazão de água é reduzida, formando um ambiente favorável à deposição e posterior degradação da matéria orgânica de forma aeróbica e anaeróbica, resultando na formação de gases $\mathrm{CO}_{2}$ e $\mathrm{CH}_{4}$.

Uma das alternativas para construção de modelos para estimativa das emissões de $\mathrm{CH}_{4}$ é via uso de informações obtidas por sensoriamento remoto, viabilizando estudo em locais com poucas informações coletadas in loco. Por exemplo, estudos demonstraram a viabilidade e a vantagem de utilizar o sensor Atmospheric Infrared Sounder (AIRS) a bordo da plataforma AQUA, para inferir e monitorizar a concentração de gases na atmosfera, oferecendo uma grande oportunidade para coletar e inferir a concentração de alguns gases-traço de efeito de estufa na atmosfera da Terra (Xiong et al., 2013; Costa et al., 2013).

$\mathrm{O}$ objetivo deste trabalho foi quantificar a concentração de $\mathrm{CH}_{4}$ no Pantanal Mato-grossense, analisar a variabilidade temporal da concentração de metano na atmosfera em função da variabilidade de precipitação pluviométrica por meio de correlação cruzada, bem como avaliar a dinâmica da concentração do gás $\mathrm{CH}_{4}$ por meio da análise wavelet (ou ondoleta) com base na série temporal de 2002-2013.

\section{MATERIAL E MÉTODO}

Este estudo foi realizado em uma área no Norte do Pantanal Mato-grossense compreendida

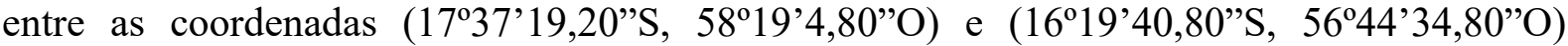
(Figura 1), altitude entre 80 a $120 \mathrm{~m}$. A região está sob domínio climático Aw, segundo a classificação de Köppen, com duas estações bem definidas, uma seca, de abril a setembro e outra úmida, de outubro a março, com precipitação média anual superior a $1300 \mathrm{~mm}$.

Os dados utilizados de $\mathrm{CH}_{4}$ foram estimados pelos sensores AIRS a bordo do satélite AQUA, no período 2002-2013, com concentrações médias diárias de taxa de mistura de $\mathrm{CH}_{4}$ (VMR, volume mixing ratio) para três níveis de pressão atmosférica $(160,5 ; 260 ; 359 \mathrm{hPa})$. Os dados AIRS são distribuídos pela NASA Goddard Earth Sciences Data Information and Services Center (DISC). A resolução espacial é $1^{\circ}$ por $1^{\circ}$ de latitude e longitude, com

Rev. Ambient. Água vol. 12 n. 3 Taubaté - May / Jun. 2017 
periodicidade diária e cobertura global. Além disso, foram utilizados dados de precipitação média diária ( $\mathrm{mm} \mathrm{dia}^{-1}$ ) obtidos pelo produto TRMM (Daily TRMM and Other Rainfall Estimate) no período de 2002-2015.

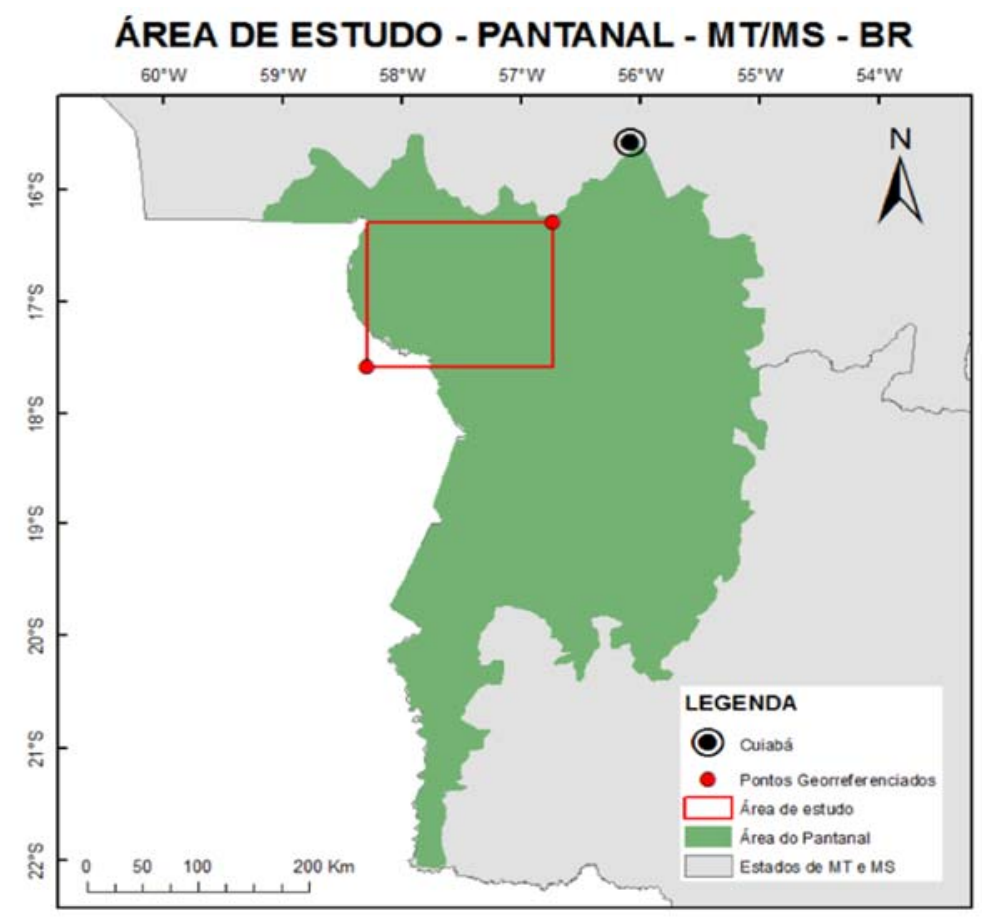

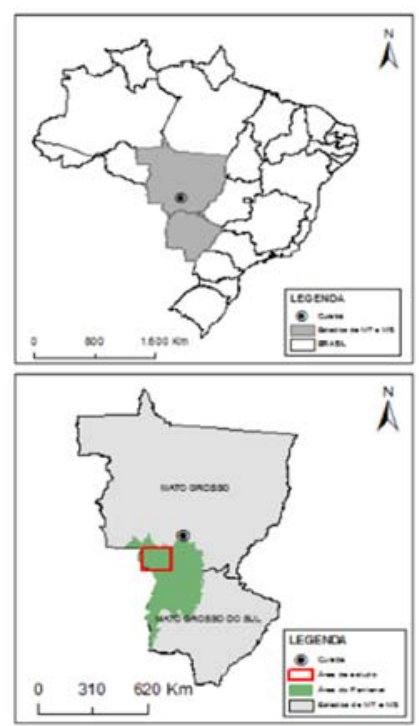

Sistema de Coordenada Geográica: SIRGAS 2000 Elaborado por: Karen F. A. P. Sallo

Figura 1. Localização da área de estudo georreferenciada e delimitada pelos pontos e pela linha em vermelho, aproximadamente $60 \mathrm{~km}$ da cidade de Cuiabá, Mato Grosso, Brasil. A área de estudo abrange pouco mais de 2 pixels.

As investigações sobre a modulação de taxa de mistura de $\mathrm{CH}_{4}$ no Pantanal foi realizada inicialmente pelo cálculo das médias de 8 dias e desvio padrão (DP) da concentração de $\mathrm{CH}_{4}$ nos três perfis de pressão atmosféricas. Esse procedimento propiciou um exploratório para variabilidade temporal. Em seguida foi removida a variabilidade anual da série para os três níveis de pressão através do cálculo da anomalia e da anomalia acumulada, com objetivo de analisar a variabilidade interanual da concentração de $\mathrm{CH}_{4}$ no período 2002-2013.

As variações temporais da concentração de $\mathrm{CH}_{4}$ foram avaliadas por meio da análise de ondoleta, que possibilitam a decomposição da série como uma função de tempo e da frequência. A ondoleta Morlet é uma função do tempo t, composta por uma exponencial complexa e modulada por uma exponencial gaussiana (Torrence e Compo, 1997). A função é da família ondoletas complexas não ortonormais dada pela Equação 1.

$$
\psi(t)=\pi^{-1 / 4} \mathrm{e}^{\mathrm{iw_{0 }} \mathrm{t}} \mathrm{e}^{-1 / 2 \mathrm{t}^{2}}, \text { para } \mathrm{w}_{0} \geq 5
$$

em que:

$\Psi$ é o valor ondoleta para um parâmetro adimensional t,

wo a frequência adimensional. Admite-se w0 $=6$ para satisfazer a condição de admissibilidade; deste modo a função deve ter média zero e ser localizada tanto no espaço tempo como na frequência (Torrence e Compo, 1997).

A ondoleta foi utilizada pelos autores Torrence e Compo (1997) e Beecham e Chowdbury (2010) na análise de séries temporais de precipitação. A técnica foi utilizada na análise de fluxo e concentração de $\mathrm{CH}_{4}$ na atmosfera por Koebsch et al. (2015) e Costa et al. (2013). Neste 
estudo, a análise de ondoleta foi aplicada utilizando-se o algoritmo elaborado por Torrence e Compo (1997).

Para as análises da série temporal de precipitação efetuou-se a média, anomalia e anomalia acumulada, usando como base o tempo mensal do período 2002-2013. Essa análise exploratória possibilitou observar padrões não-sazonais e variações ao longo da série. Posteriormente, realizou-se a análise de correlação cruzada em escala semanal para as séries de anomalia de chuva e anomalia de concentração de $\mathrm{CH}_{4}$ para o mesmo período de dados da precipitação 2002-2013.

\section{RESULTADO E DISCUSSÃO}

Observa-se uma relação entre as séries da concentração de $\mathrm{CH}_{4}$ e a precipitação, sendo possível observar máximos coincidentes (Figura 2). Detectou-se sazonalidade nas concentrações de $\mathrm{CH}_{4}$ nos níveis de pressão (Figura 2), com as maiores concentrações no nível de 359 mb com média ( \pm DP) $1766 \pm 10$ ppbv. Ao nível de pressão de $160 \mathrm{mb}$, a média $( \pm \mathrm{DP})$ da concentração foi $1728 \pm 17$ ppbv, apresentando maior amplitude entre as concentrações máximas e mínimas. Também, é mais aparente a sazonalidade da concentração do $\mathrm{CH}_{4}$ em nível de pressão $160 \mathrm{mb}$, com uma média $( \pm \mathrm{DP})$ de $1728 \pm 17 \mathrm{ppbv}$, porém menos evidente em 359 $\mathrm{mb}$. Esse resultado foi semelhante aos trabalhos de Costa et al. (2013) e Ribeiro et al. (2016), que trabalharam com dados de sensoriamento relativos a áreas alagadas no Estado do Amazonas. Do mesmo modo, houve uma diminuição da concentração de $\mathrm{CH}_{4}$ em função da diminuição dos níveis de pressão, sendo justificada pelos principais processos de remoção de $\mathrm{CH}_{4}$ da atmosfera, que são a reação de $\mathrm{CH}_{4}$ com radicais hidroxila $\left(\mathrm{OH}^{-}\right)$na troposfera e estratosfera e com átomos de oxigênio na estratosfera (Dlugokencky et al., 2011). Resultados semelhantes também foram obtidos por Alvalá et al. (2004), que analisaram a concentração de $\mathrm{CH}_{4}$ na região do Atlântico Sul com medidas realizadas a $25 \mathrm{~km}$ da costa brasileira, utilizando a método trajetórias isentrópicas, observando uma variação sazonal com uma média $( \pm \mathrm{DP})$ de $1707 \pm 8$ ppbv.

Durante a estação seca (maio a setembro), verificou-se a média ( \pm DP) das concentrações de $\mathrm{CH}_{4}$ de $1736 \pm 16 ; 1754 \pm 10$ e $1765 \pm 11$ ppbv nos níveis pressão 160,5; 260 e $359 \mathrm{mb}$, respectivamente. Enquanto que durante a estação chuvosa (janeiro a abril) as médias $( \pm \mathrm{DP})$ foram $1720 \pm 14 ; 1746 \pm 11$ e $1751 \pm 16$ ppbv em nível de pressão 160,5; 260 e 359 mb, respectivamente. As maiores concentrações de $\mathrm{CH}_{4}$ durante a estação seca, de acordo com Spivakovsky et al. (1990) e McNorton et al. (2016), podem ser explicadas pela sazonalidade do radical $\mathrm{OH}^{-}$na troposfera e estratosfera. Ainda Spivakovsky et al. (1990) sugerem que, na latitude próxima à região de estudo, a concentração de $\mathrm{OH}^{-}$é maior no período chuvoso, servindo como sumidouro de $\mathrm{CH}_{4}$. Conforme observado por Marani e Alvala (2006), a variação de fluxo de $\mathrm{CH}_{4}$ está associada à variação anual de área alagada no pantanal, que por sua vez está relacionada a sazonalidade de precipitação. De acordo com os resultados de Ribeiro et al., (2016), ocorre um pico de precipitação seis meses antes do maior pico de concentração de $\mathrm{CH}_{4}$, na região da Amazônia. E ainda Bastviken et al. (2010), sugerem que o metabolismo de matéria orgânica está relacionado à estação hidrológica - com a crescente das águas no Pantanal, ocorre a maior taxa de metabolismo de matéria orgânica.

É possível observar um padrão das anomalias ao longo de toda a série, entretanto foi notado um aumento das anomalias positivas a partir de $2007 \mathrm{e}$, posteriormente, aumento das anomalias negativas após 2011 (Figura 3A). Este resultado pode ser verificado (Figura 3A) pelas séries de anomalia acumulada, onde é possível observar uma tendência de diminuição da precipitação nos primeiros 4 anos da série e, posteriormente, aumento das anomalias positivas em 2007, e após 2011 apareceu aumento de anomalias negativas. Esse resultado foi consistente com o de

Rev. Ambient. Água vol. 12 n. 3 Taubaté - May / Jun. 2017 
Penatti et al. (2015), que verificaram, por sensoriamento remoto, mudanças espaço-temporais das variáveis do balanço hídrico no Pantanal. Anomalias positivas de estoque de água terrestre medidos foram maiores nos anos de 2006, 2007, 2008 e 2011, com menor pico ocorrido em 2012. Hamilton et al. (2002) destacaram que a maior parte da variabilidade climática observada é conduzida pelas anomalias na temperatura superficial das águas do Oceano Pacífico, com os fenômenos El Niño e La Niña influenciando diretamente na taxa de precipitação na bacia pantaneira e seus afluentes. Nesse contexto, um fator importante na emissão de $\mathrm{CH}_{4}$ no Pantanal para a atmosfera é a extensão espacial da área alagada. Essa extensão é primariamente controlada pela variação sazonal do nível dos rios e pelo acúmulo de água da precipitação. Com base em dados de satélite, Hamilton et al. (2002) obtiveram estimativas sobre o alagamento no Pantanal, os quais foram utilizados para estimativas de emissão de $\mathrm{CH}_{4}$ do Pantanal.

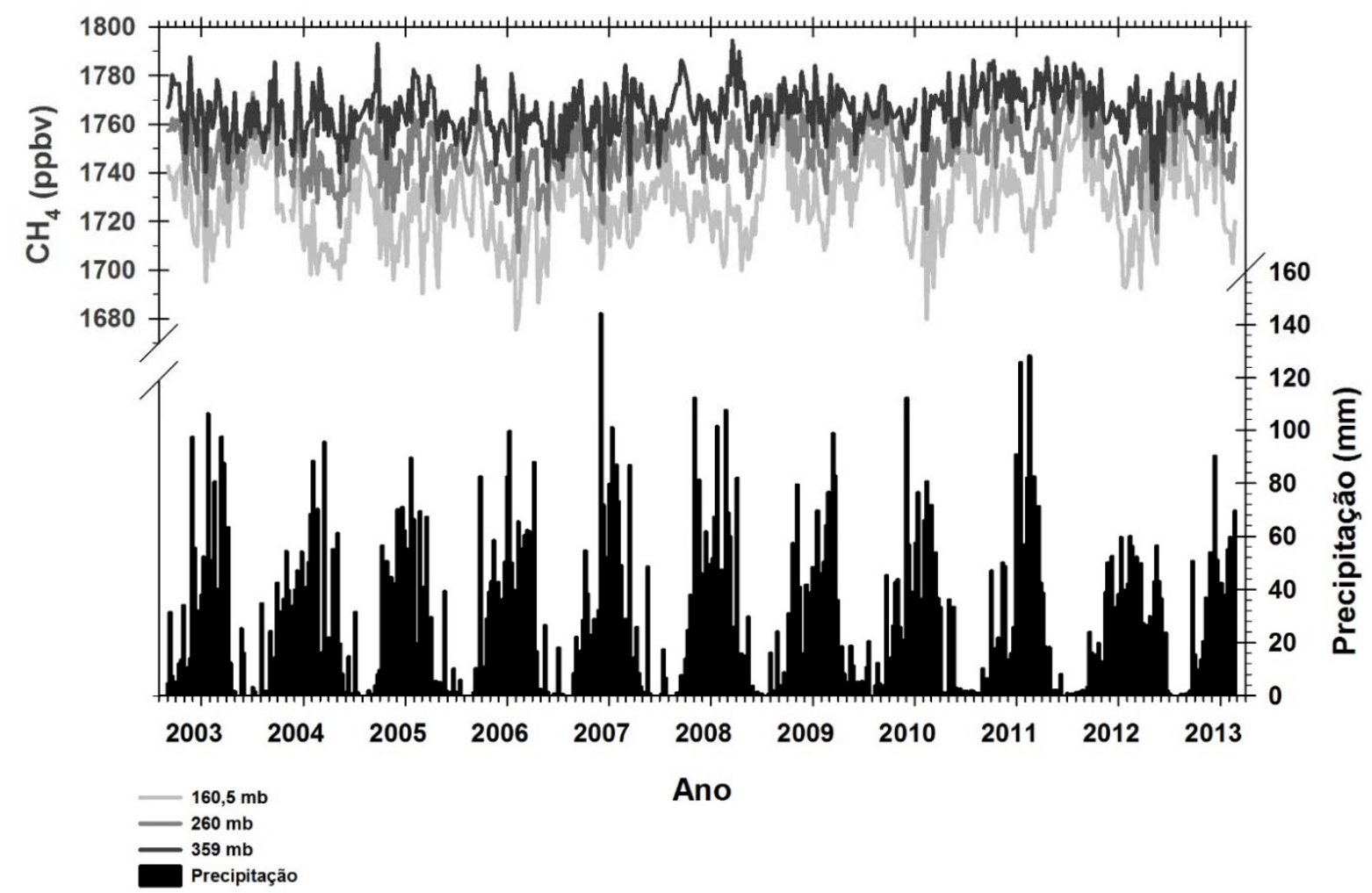

Figura 2. Série temporal de concentração média de 8 dias de $\mathrm{CH}_{4}$, e de precipitação sobre a região do Pantanal Mato-grossense, de 2002 a 2013. As linhas em tom de cinza (acima) com escala a esquerda em três níveis de pressão atmosférica, iniciando mais acima na escala $359 \mathrm{mb}, 260 \mathrm{mb}$ e 160,5 mb, terminando mais abaixo na escala, respectivamente. Na parte inferior da figura em preto com escala à direita, observa-se a série de precipitação.

Nas análises da anomalia da concentração de $\mathrm{CH}_{4}$ (Figura 3) observa-se que em geral houve aumento das anomalias positivas de concentração de $\mathrm{CH}_{4}$ a partir de $2007 \mathrm{em}$ todos os níveis de pressão atmosférica, sendo menos evidente no nível $359 \mathrm{mb}$ (Figura 3C). Nota-se também a predominância de negativos das anomalias entre os anos de 2003 a 2007. Contudo, a maior variabilidade da anomalia ocorreu no nível de pressão 160 mb (Figura 3A), entre 49,6 a $-52,6$ ppbv. A tendência da dinâmica de concentração de $\mathrm{CH}_{4}$ pode ser observada na série de anomalia acumulada (Figura 3) pelo decréscimo da concentração de $\mathrm{CH}_{4}$ para 2002-2006, e aumento em 2007 a 2013, nos níveis de pressão analisados. 
$\mathrm{Na}$ anomalia acumulada da precipitação (Figura 3D) observa-se dois comportamentos que governam as oscilações das anomalias de $\mathrm{CH}_{4}$. $\mathrm{O}$ primeiro refere-se às variações sub-anuais de $\mathrm{CH}_{4}$, que é inversamente proporcional ao ciclo anual de precipitação. O segundo refere-se ao aumento da concentração de $\mathrm{CH}_{4}$ a partir de 2008, que tem origem do aumento progressivo do alagamento a partir de 2006 até 2012. O aumento de alagamento estar relacionado as variações interanuais de precipitação, que por sua vez estão relacionadas com os fenômenos de El Niño e La Niña (Ribeiro et al., 2016).

A
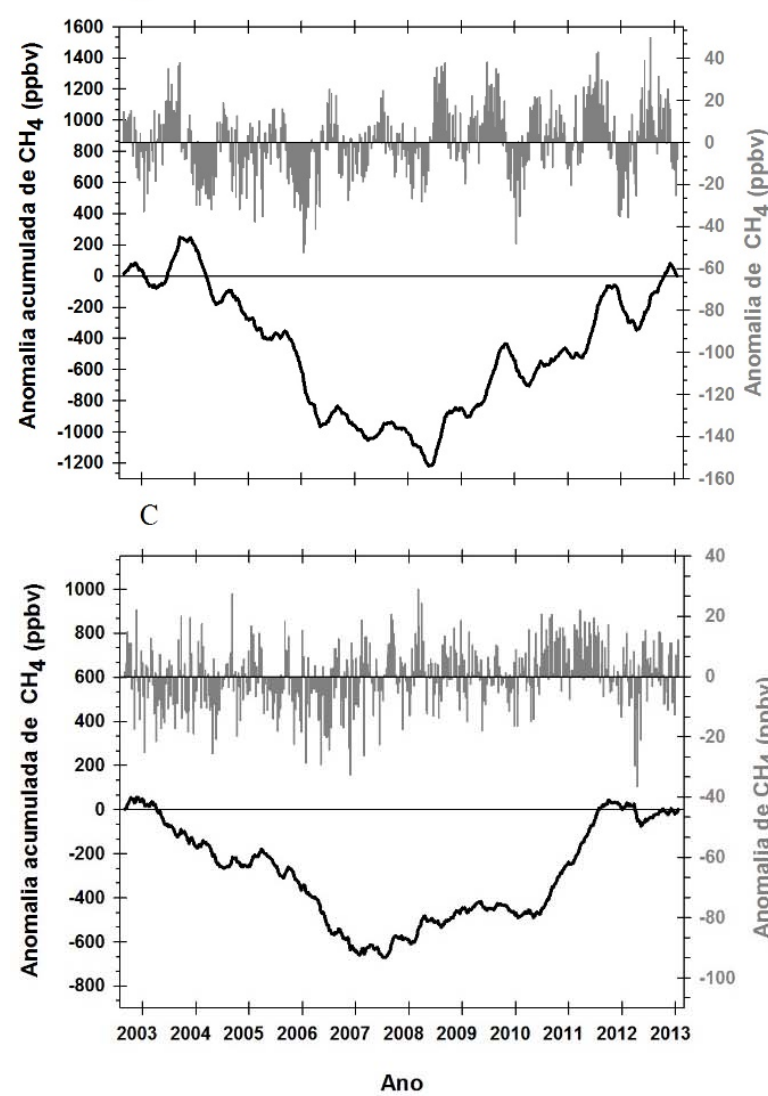

B

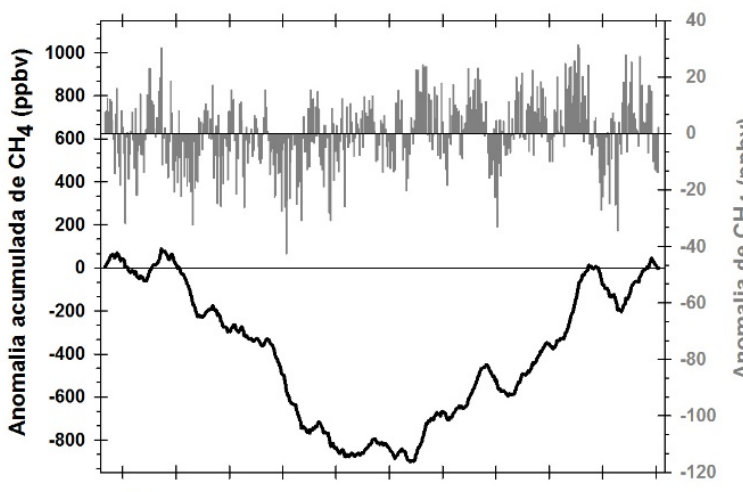

D

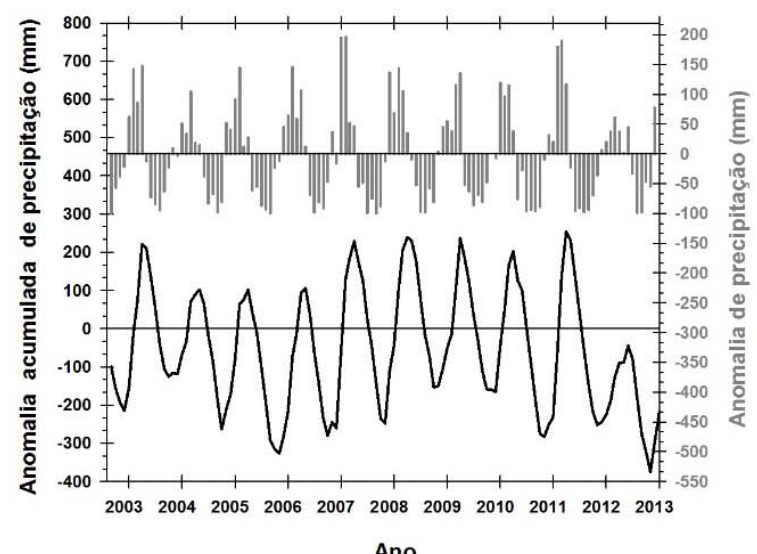

Ano

Figura 3. Variabilidade e tendência na concentração de $\mathrm{CH}_{4}$ e precipitação na atmosfera ao longo da série histórica. A variação interanual de anomalia de $\mathrm{CH}_{4}$ e precipitação pode ser observada na escala à direita em cinza. Na escala à esquerda na cor preta à anomalia acumulada, observa-se a tendência de acréscimo e decréscimo de concentração de $\mathrm{CH}_{4}$ e precipitação ao longo da série. Análises para os níveis $359 \mathrm{mb}$ (C), $260 \mathrm{mb}$ (B) e $160 \mathrm{mb}$ (A) de pressão atmosférica e precipitação (D).

Essa variabilidade interanual da concentração de $\mathrm{CH}_{4}$ (Figura 3A) pode ser explicada pela variabilidade interanual de precipitação (Figura 3D), com aumento das anomalias de precipitação e consequente aumento das áreas alagadas. Conforme Bousquet et al. (2006), áreas úmidas tem papel dominante na emissão de $\mathrm{CH}_{4}$ para atmosfera, variando em torno de ( $\pm 12 \mathrm{Tg} \mathrm{CH}_{4}$ ano $^{-1}$ ) explicando $70 \%$ das anomalias globais durante as duas últimas décadas. A variabilidade do $\mathrm{CH}_{4}$ em escala regional, como é o caso, está em concordância com a precipitação acumulada, sendo possível afirmar que existe uma correlação negativa entre as mesmas, justificada pelo pico máximo de precipitação coincidir com o mínimo de concentração de $\mathrm{CH}_{4}$, comparadas no mesmo período 2002-2013 e mesma resolução temporal de 8 dias.

A análise da série temporal da anomalia de concentração de $\mathrm{CH}_{4}$ com relação à anomalia de precipitação a partir de correlação cruzada determinou o tempo de defasagem entre as séries a 
fim de estabelecer o grau de associação entre estas (Figura 4). Verifica-se que para uma defasagem igual a zero a correlação é negativa, mostrando de forma geral que um aumento na altura precipitada reduz a emissão de $\mathrm{CH}_{4}$. Por outro lado, observam-se coeficientes de defasagem positivos em média 24 semanas depois dos picos negativos de defasagens, onde há as alturas maiores de precipitação. Isso é indicativo de que a diminuição da precipitação no Pantanal Mato-grossense influencia no aumento da emissão de $\mathrm{CH}_{4}$ para a atmosfera após aproximadamente 24 semanas, acompanhado por um decréscimo subsequente. Em medidas de superfície, a emissão de $\mathrm{CH}_{4}$ é maior no período chuvoso (Alvalá e Kirchhoff, 2000; Marani e Avalá, 2006; Da Silva et al., 2016). Contudo, existe um certo atraso entre o pico de chuva e pico de emissão de metano (Marani e Avalá, 2007) devido ao intervalo de tempo necessário para os processos de aumento do nível da lâmina d'água e aumento da metabolização anaeróbica pelas bactérias (metanogênicas) (Da Silva et al., 2016). Além disso, existe um intervalo entre os picos de emissão de superfície e o aumento da concentração na alta atmosfera (Ribeiro et al., 2016).

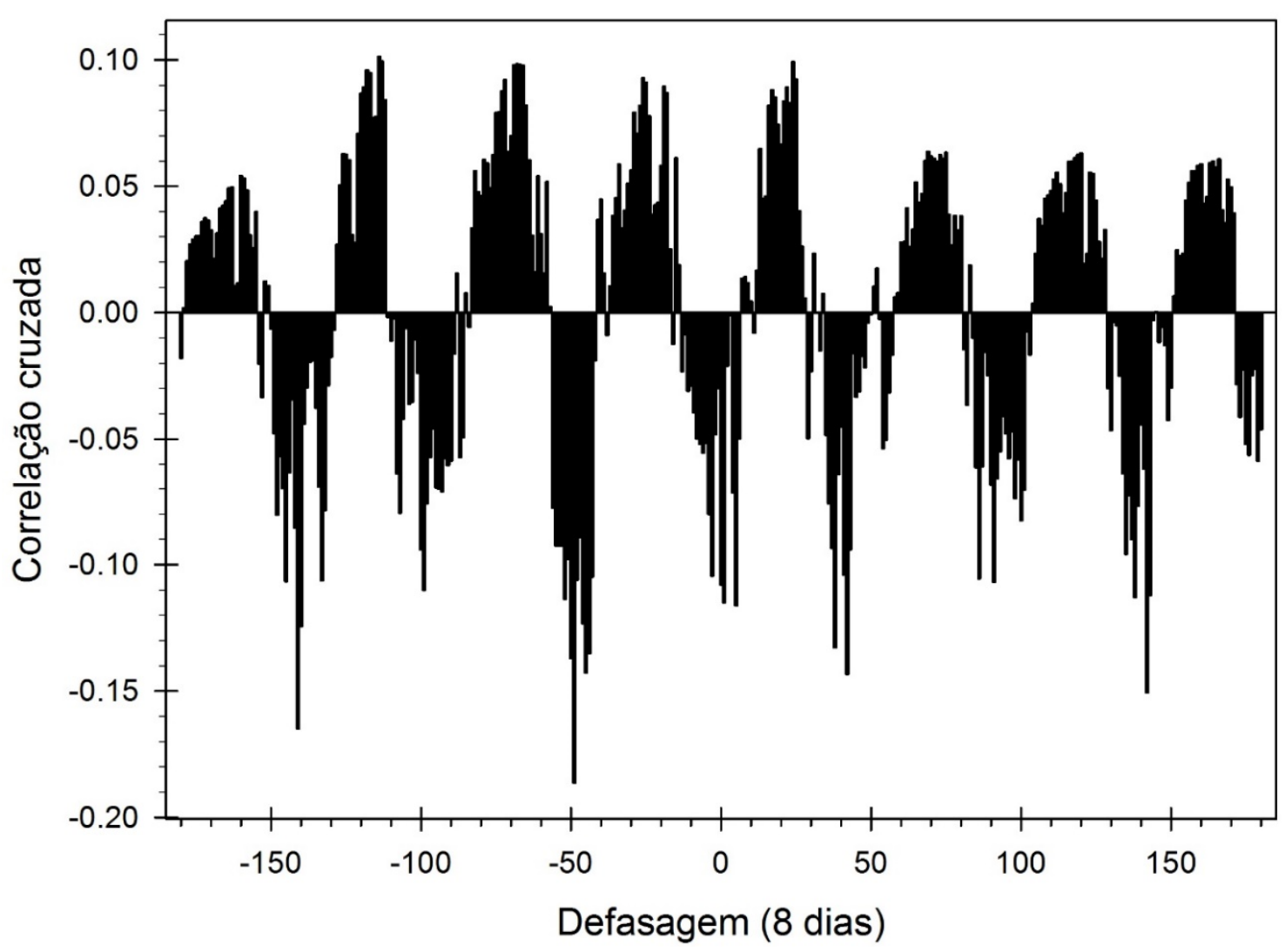

Figura 4. Correlação cruzada entre a série temporal de anomalia de precipitação e anomalia concentração do $\mathrm{CH}_{4}$ do período de 2002-2013. A escala defasagem representa o tempo de resposta do $\mathrm{CH}_{4}$ em relação à variação da precipitação.

Resultados de emissões pontuais e curto intervalo de tempo são reportados por vários estudos sendo incapazes de mostrar a dinâmica das emissões. Bastviken et al. (2010), mediram o fluxo de $\mathrm{CH}_{4}$ em 16 lagos na região do Pantanal Mato-grossense, realizando uma extrapolação utilizando a média de área alagada $\left(38880 \mathrm{~km}^{2}\right)$. O Pantanal produz um fluxo de 1,9 $\mathrm{Tg} \mathrm{CH} 4$ ano $^{-1}$. Estes resultados podem ser comparados aos de Marani e Alvalá (2006), que analisaram locais próximos ao rio Miranda também na região do Pantanal Mato-grossense, e ao utilizarem uma média maior de área alagada, obtiveram o valor de $3,3 \mathrm{Tg} \mathrm{CH}_{4}$ ano $^{-1}$, que representa 3,3\% da contribuição global de áreas alagadas. Os fluxos difusivos são 
correlacionados principalmente com características físico-químicas relacionadas ao aumento de matéria orgânica durante o alagamento no Pantanal (Da Silva et al., 2016). Áreas alagadas que compreendem florestas, ou que estão próximas a rios no Pantanal, tem altas taxas de produtividade bruta primaria, alta temperaturas e elevada radiação solar, resultando no aumento da taxa de decomposição, que por sua vez contribui no acréscimo de fluxo de $\mathrm{CH}_{4}$ para atmosfera (Bastviken et al., 2010).

$\mathrm{Na}$ análise da transformada ondoleta é possível identificar pela Figura 5A dois ciclos com intensidades de energia predominantes ao longo da série temporal de concentração de $\mathrm{CH}_{4} \mathrm{em}$ nível de pressão $260 \mathrm{mb}$ (2002-2013). Assim observa-se pela faixa da escala de cor no espectro de potência da Figura 5A que ocorreram ciclos na escala anual \pm 1 ano de 2004 a 2011 . O segundo ciclo foi interanual de \pm 2 anos de 2005 a 2011, com o conjunto de valores significativos delimitados pelo cone de influência. Este ciclo interanual de concentração de $\mathrm{CH}_{4}$ também foi observado por Marani e Alvalá (2006). Como também, ciclos aproximadamente anuais, mas de maior intensidade de energia (escala de 50 a 60 no espectro de potência ondoleta), ocorreram em período de 2006 a 2011. A intensidade de energia no período de 2006-2011 identificada na análise ondoleta, pode ser justificada pelo aumento na anomalia de precipitação.

Observa-se pelo espectro de potência global (Figura 5B), que os ciclos anual e interanual contêm as maiores variâncias, e além disso a variância do ciclo anual é maior e está, a maior parte, dentro do limite significativo.

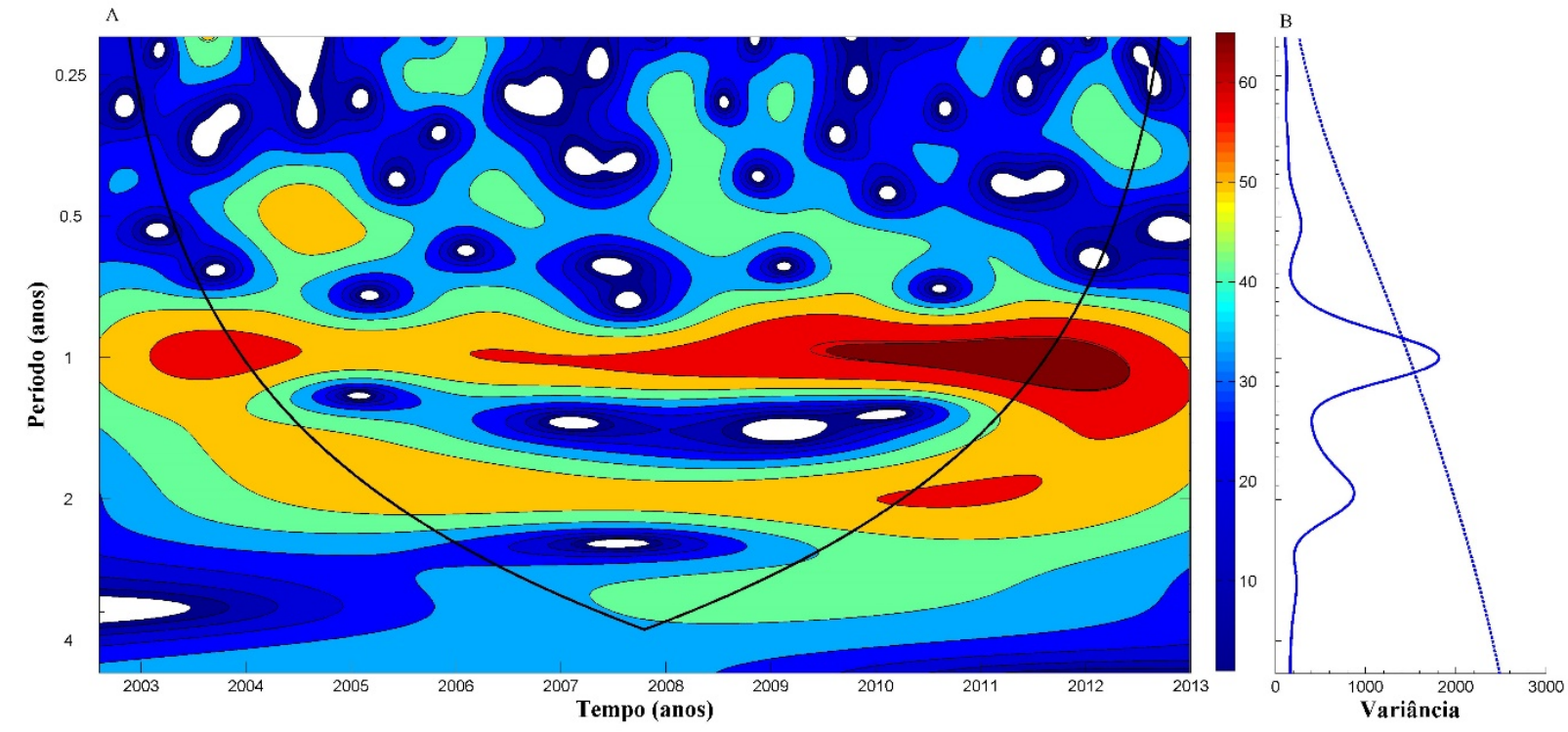

Figura 5. (A) Espectro de potência ondoleta. A região delimitada pela linha curva em forma de U representa o cone de influência (nível de 95\% de significância). (B) Espectro de potência global (linha azul). A linha pontilhada em azul é o nível de significância de $95 \%$ para o espectro global.

O resultado pode ser explicado pela variabilidade interanual observada pela anomalia da concentração de $\mathrm{CH}_{4}$. Portanto, a análise ondoleta reforça o resultado observado pela análise de anomalia de concentração de $\mathrm{CH}_{4}$. Houve variabilidade interanual e características cíclicas tanto em escala anual como interanual de concentração de $\mathrm{CH}_{4}$. $\mathrm{O}$ ciclo de maior predominância da periodicidade (acima de 60) foi aproximadamente 0,9 a 1 ano de ocorrência na segunda metade de 2009, em que esse ciclo variava entre a faixa 0,9 a 1,3 (Figura 5A) até meados de 2012; mas ele foi significativo até 2011 conforme delimitação da curva em forma de U (cone de influência na Figura 5A), justificado pela sazonalidade anual da precipitação no Pantanal. O cone de influência também indica que nenhum ciclo é significativo acima de 4 anos. Esses 
resultados são semelhante ao de Costa et al., (2014) e Ribeiro et al., (2016) com dados de sensoriamento relativos a áreas alagadas no Estado do Amazonas.

\section{CONCLUSÃO}

A investigação sobre o $\mathrm{CH}_{4}$ na atmosfera possibilitou analisar perturbações importantes na variabilidade da série temporal de concentração de $\mathrm{CH}_{4}$ sobre a região do Pantanal Mato-grossense de 2003-2013. Primeiramente observou-se um padrão sazonal da concentração de $\mathrm{CH}_{4}$ consistente com a sazonalidade da precipitação. Em escala anual, uma maior altura precipitada ocasionou maior concentração de $\mathrm{CH}_{4}$. Entretanto, em escala semanal observou-se pela análise de correlação cruzada que existe correlação negativa entre anomalia de chuva e concentração de $\mathrm{CH}_{4}$ na atmosfera com defasagem de 24 semanas, ocorrendo maior concentração de $\mathrm{CH}_{4}$ durante a estação seca. Esta defasagem corresponde ao intervalo de tempo necessário para a ampliação de área alagada como condição favorável a uma maior quantidade de decomposição de biomassa, que ocasiona emissões de $\mathrm{CH}_{4}$ para a atmosfera durante a estação subsequente. Ela também pode estar relacionada a um consumo de $\mathrm{CH}_{4}$ pelo radical $\mathrm{OH}^{-}$, que é seu principal sumidouro na atmosfera no período chuvoso.

Detectou-se variabilidade interanual de $\mathrm{CH}_{4}$ ao longo do período de 2002-2013, com aumento das anomalias positivas a partir de 2007, possivelmente relacionada ao acréscimo de anomalias positivas de precipitação a partir de 2006. Na análise ondoleta, observou-se ciclos anuais que ocorrem ao longo de quase toda série de temporal, variando entre 0,9 a 1,3 anos intensificando a partir de 2009 até 2013, indicando estar relacionado com a sazonalidade da precipitação e com um incremento da concentração de $\mathrm{CH}_{4}$. Contudo, houve ciclos interanuais variando aproximadamente de 1,5 a 2 anos.

Análises da concentração de $\mathrm{CH}_{4}$ sobre o Pantanal fornecem contribuições importantes sobre a dinâmica do $\mathrm{CH}_{4}$ na média e alta troposfera. Essas informações podem dar suporte a gestão de hídricos, e ainda ajudar no conhecimento de futuras mudanças climáticas e delinear estratégias de mitigação.

\section{REFERENCIAS}

ALVALÁ, P. C.; BOIAN, C.; KIRCHHOFF, V. W. J. H. Measurements of $\mathrm{CH}_{4}$ and $\mathrm{CO}_{2}$ during ship cruises in the South Atlantic. Atmospheric Environment, v. 38, p. 4583-4588, 2004. http://dx.doi.org/10.1016/j.atmosenv.2004.03.042

ALVALÁ, P. C.; KIRCHHOFF, V. W. J. H. Methane fluxes from the Pantanal floodplain in Brazil: seasonal variation. In: VAN HAM, J.; BAEDE, A. P. M.; MEYER, L. A.; YBEMA, R. (Eds.). Non-CO2 Greenhouse Gases: Scientific Understanding, Control and Implementation. Netherlands: Springer, 2000. p. 95-99. http://dx.doi.org/10.1007/978-94-015-9343-4_6

BASTVIKEN, D.; SANTORO, A. L.; MAROTTA, H.; PINHO, L. Q.; CALHEIROS, D. F.; CRILL, P. Methane emissions from Pantanal, South America, during the low water season: toward more comprehensive sampling. Environmental Science and Technology, v. 44, n. 14, p. 5450-5455, 2010. http://dx.doi.org/10.1021/es1005048

BEECHAM, S.; CHOWDHURY, R. K. Temporal characteristics and variability of point rainfall: a statistical and Wavelet analysis. International Journal of Climatology, v.30, p. 458-473, 2010. http://dx.doi.org/10.1002/joc.1901 
BOUSQUET, P.; CIAIS, P.; MILLER, J. B.; DLUGOKENCKY, E. J.; HAUGLUSTAINE, D. A.; PRIGENT, C. et al. Contribution of anthropogenic and natural sources to atmospheric methane variability. Nature, v.443, p. 439-443, 2006.

http://dx.doi.org/10.1038/nature05132

COSTA, P. S.; SIlVA, J. V.; SOUZA, R. A. F.; SOUZA, R. V. A.; JÚNIOR, N. P. F.; CARTAXO, E. F. Monitoring of Methane on Dams of hydroelectrics of the Amazon Basin from the Aqua Satellite information. Journal of Hyperspectral Remote Sensing, v.4, p. 19-30, 2013.

DA SILVA, M. G.; ALVALÁ, P. C.; MARANI, L.; FERREIRA, W. J. Análise da influência de parâmetros ambientais no fluxo de metano em áreas alagáveis e lagoas permanentes na região do Rio Abobral, no Pantanal, Brasil. Revista Ambiente \& Água, v. 11, n. 2, p. 327-338, 2016. http://dx.doi.org/10.4136/ambi-agua.1775

DLUGOKENCKY, E. J.; NISBET, E. G.; FISHER, R.; LOWRY, D. Global atmospheric methane: budget, changes and dangers. Royal Society Publishing, v.369, p.2058-2072, 2011. http://dx.doi.org/10.1098/rsta.2010.0341

HAMILTON, S. K.; SIPPEL, S. J.; MELACK, J. M. Comparison of inundation patterns among major South American floodplains. Journal of Geophysical Research, v.107, p. 1-14, 2002. http://dx.doi.org/10.1029/2000jd000306

KOEBSCH, F.; JURASINSKI, G.; KOCH, M.; HOFMANN, J. Controls for multi-scale temporal variation in ecosystem methane exchange during the growing season of a permanently inundated fen. Agricultural and Forest Meteorology, v.204 p. 94-105, 2015. http://dx.doi.org/10.1016/j.agrformet.2015.02.002

MARANI, L.; ALVALA, P. C. Methane emissions from lakes and floodplains in Pantanal, Brazil. Atmospheric Environment, v.41, p.1627-1633, 2006.

http://dx.doi.org/10.1016/j.atmosenv.2006.10.046

MELTON, J. R.; WANIA, R.; HODSON, E. L.; POULTER, B.; RINGEVAL, B.; SPAHNI, R. et al. Present state of global wetland extent and wetland methane modelling: conclusions from a model intercomparison project (WETCHIMP). Biogeosciences, v. 10, p. 753-788, 2013. http://hdl.handle.net/11858/00-001M-0000-000F-ED12-B

MCNORTON, J.; CHIPPERFIELD, M. P.; GLOOR, M.; WILSON, C.; FENG, W.; HAYMAN, G. D. et al. Role of $\mathrm{OH}$ variability in the stalling of the global atmospheric $\mathrm{CH}_{4}$ growth rate from 1999 to 2006. Atmospheric Chemistry and Physics, p. 1-24, 2016. http://dx.doi.org/10.5194/acp-2015-1029

PENATTI, N. C.; RIBEIRO, A. T. I.; FERREIRA, L. G.; ARANTES, A. E.; COE, M. T. Satellite-based hydrological dynamics of the world's largest continuous wetland. Remote Sensing of Environment, p. 1-13, 2015. http://dx.doi.org/10.1016/j.rse.2015.08.031

RIBEIRO, I. O.; DE SOUZA, R. A. F.; ANDREOLI, R. V.; KAYANO, M. T.; DOS SANTOS COSTA, P. Spatiotemporal variability of methane over the Amazon from satellite observations. Advances in Atmospheric Sciences, v. 33, n. 7, p. 852-864, 2016. http://dx.doi.org/10.1007/s00376-016-5138-7 
SPIVAKOVSKY, C. M.; YEVICH, R.; LOGAN, J. A.; WOFSY, S. C.; MCELROY, M. B.; PRATHER, M. J. Tropospheric $\mathrm{OH}$ in a three-dimensional chemical tracer model: An assessment based on observations of $\mathrm{CH} 3 \mathrm{CCl} 3$. Journal of Geophysical Research: Atmospheres, v. 95, n. D11, p. 18441-18471, 1990. http://dx.doi.org/10.1029/JD095iD11p18441

TORRENCE, C.; COMPO, G. P. A Practical Guide to Wavelet Analysis. Bulletin of the American Meteorological Society, v.79, p. 61-78, 1997. http://dx.doi.org/10.1175/1520-0477(1998)079\%3C0061:APGTWA\%3E2.0.CO;2

VOURLITIS, G. L.; LOBO, F. A.; LAWRENCE, S.; LUCENA, I. C; PINTO Jr., O. B.; DALMAGRO, H. J.; et al. Variations in Stand Structure and Diversity along a Soil Fertility Gradient in a Brazilian Savanna (Cerrado) in Southern Mato Grosso. Forest, Range \& Wildland Soils, p. 1370-1379, 2013. http://dx.doi.org/10.2136/sssaj2012.0336

XIONG, X.; BARNET, C.; MADDY, E.; WOFSY, S. C.; CHEN, L.; KARION, A. et al. Detection of methane depletion associated with stratospheric intrusion by atmospheric infrared sounder (AIRS), Geophysical Research Letters, v.40, p. 2455-2459, 2013. http://dx.doi.org/10.1002/grl.50476 


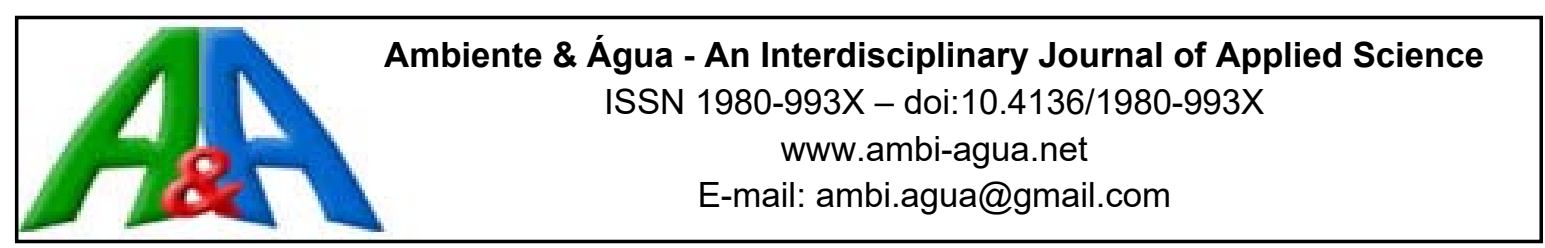

\title{
Efetividade do ensaio Trad-MCN para avaliação de contaminantes atmosféricos em regiões brasileiras
}

\author{
doi:10.4136/ambi-agua.2049 \\ Received: 24 Nov. 2016; Accepted: 20 Mar. 2017

\begin{abstract}
Juliana Caroline Vivian Sposito; Luiza Flávia Veiga Francisco; Alexeia Barufatti Grisolia*
\end{abstract} \\ Universidade Federal da Grande Dourados (UFGD), Dourados, MS, Brasil \\ *Autor correspondente: e-mail: alexeiagrisolia@ufgd.edu.br, \\ juliana_sposito@hotmail.com, luizaveiga10@hotmail.com
}

\section{RESUMO}

A planta Tradescantia pallida (Rose) D.R. Hunt var. purpurea tem sido utilizada em diversos modelos experimentais para detecção de danos morfofisiológicos e genéticos, por ser uma planta sensível a poluentes atmosféricos. No entanto, dentre os biotestes utilizados para avaliação do potencial mutagênico de contaminantes ambientais, o bioensaio de micronúcleo em Tradescantia (Trad-MCN) é um dos testes mais utilizados em estudos de monitoramento das condições atmosféricas. Diante do exposto, foi realizada uma revisão de literatura, identificando regiões brasileiras que utilizaram o bioensaio de micronúcleo em Tradescantia para monitorar alterações genéticas advindas da contaminação atmosférica. $\mathrm{O}$ levantamento de trabalhos indexados foi realizado em bancos de referência, como Portal de Períodicos CAPES, SciELO, ScienceDirect e PubMed, sendo os mesmos investigados quanto às regiões brasileiras biomonitoradas, período, área, exposição, monitoramento ativo ou passivo e planta natural ou clone. Os resultados indicaram que pesquisas baseadas no bioensaio Trad-MCN foram realizadas em diversas regiões brasileiras. Verificou-se que a maioria dos trabalhos são oriundos da região sudeste, especialmente do estado de São Paulo. Esse fato pode ser atribuído ao maior número de indústrias e automóveis em circulação existentes neste estado quando comparado aos demais, podendo interferir diretamente na qualidade do ar, despertando assim o interesse no meio científico. Com base nesta investigação, o bioensaio Trad-MCN revelou eficácia, e a planta Tradescantia demonstrou ser importante indicadora biológica de danos genéticos ocasionados pela exposição aos poluentes atmosféricos, e é amplamente utilizada na região sudeste do país.

Palavras-chave: bioindicador, micronúcleos, Tradescantia.

\section{Effectiveness of the Trad-MCN assay for the evaluation of atmospheric contaminants in Brazilian regions}

\section{ABSTRACT}

The Tradescantia pallida (Rose) D.R. Hunt var. purpurea plant has been used in several experimental models to detect morphophysiological and genetic damage due its susceptibility to atmospheric pollutants. However, among the bioassays used to evaluate the mutagenic potential of environmental contaminants, the Tradescantia-Micronucleus (Trad-MCN) 
bioassay is one of the most-used tests in studies of atmospheric conditions monitoring. A review of literature was therefore carried out, identifying Brazilian regions where the micronucleus bioassay in Tradescantia was used to monitor genetic alterations caused by atmospheric contamination. Reference banks were used to survey the indexed studies, such as portal CAPES, SciELO, ScienceDirect and PubMed, which were investigated regarding the Brazilian biomonitored region, period, area, exposure, active or passive monitoring and natural plant or clone. The results indicated that research based on the Trad-MCN bioassay was performed in several Brazilian regions. The review verified that the majority of the studies come from the southeast region, especially from the state of São Paulo. This fact can be explained by the greater number of industries and automobiles in circulation in this state as compared to others, which can directly interfere with air quality thus arousing the interest of the scientific community. Based on this review, the Trad-MCN bioassay has been demonstrated to be effective and the Tradescantia plant has been shown to be an important biological indicator of genetic damage caused by exposure to air pollutants and is widely used in the southeastern region of the country.

Keywords: bioindicator, micronuclei, Tradescantia.

\section{INTRODUÇÃO}

O biomonitoramento corresponde a um método experimental que possibilita detectar impactos ocasionados por poluentes nos organismos vivos, conhecidos como bioindicadores (Carneiro e Takayanagui, 2009). Estes organismos fornecem informações sobre alterações morfológicas e/ou fisiológicas que ocorrem nos mesmos, quando expostos a ambientes que passaram por mudanças físico-químicas e se encontram degradados (Klumpp et al., 2004).

As plantas têm sido frequentemente utilizadas por apresentarem vantagens em relação aos métodos convencionais, como: avaliação de efeitos em linhagens germinativas, visualização de danos genéticos em células individuais, sensibilidade, baixo custo operacional, rápida execução, maior número de amostragens, além de fácil adaptação podendo se desenvolver durante todo o ano, apresentando-se como um instrumento favorável para estudos de biomonitoramento (Carvalho, 2005; Catinon et al., 2008; De Souza et al., 2016).

As plantas bioindicadoras possuem sensibilidade às alterações do ambiente, fornecendo informações importantes no monitoramento de poluentes atmosféricos. Essa sensibilidade pode ser atribuída à principal via de entrada de poluentes, os estômatos, por onde são realizadas trocas gasosas, verificando-se danos macroscópicos como aparecimento de cloroses, necroses, queda de folhas ou diminuição no seu crescimento, bem como em nível genético, fisiológico ou bioquímico (Alves et al., 2001; Savóia, 2007).

Algumas plantas do gênero Tradescantia são conhecidas como importantes ferramentas em estudo de biomonitoramento, como a Tradescantia pallida (Rose) Hunt var. purpurea Boom e o clone 4430 (Meireles e Cerqueira, 2011).

\subsection{Clone 4430 x Tradescantia pallida}

Em 1978, Ma e colaboradores padronizaram teste utilizando Clone BNL 4430, um híbrido estéril (Tradescantia hirsutiflora $\times$ Tradescantia subcaulis) do gênero Tradescantia, contendo $2 \mathrm{n}=12$ cromossomos (todos metacêntricos). Esta esterilidade certifica a homogeneidade genética do clone na ausência de efeitos mutagênicos (White e Claxton, 2004). Desde então, o referido clone tem sido utilizado como bioindicador no monitoramento de poluentes atmosféricos. 
Entretanto, o Clone 4430 tem aplicações limitadas em países tropicais, dada sua sensibilidade ao clima (temperatura e umidade do ar elevadas) e aos ataques de insetos quando expostas por períodos prolongados em ambiente aberto, limitando seu uso para estudos de biomonitoramento (Sant'Anna, 2003).

Neste contexto, a espécie Tradescantia pallida tem sido largamente usada como planta bioindicadora apresentando resistência natural às intempéries da natureza, além de fácil propagação (Suyama et al., 2002). A Tradescantia pallida (Rose) D.R Hunt var. purpurea (Commelinaceae), originária do México, corresponde a uma espécie de planta herbácea indicadora biológica, suculenta, de $15-25 \mathrm{~cm}$ de altura, anual ou perene, raramente epífita, ereta a decumbente. Planta decorativa de cor roxa, com folhas alternas inteiras, com bainhas envolvendo o caule, pubescentes, possui inflorescência cimosa, racemosa ou capitata, com brácteas pequenas a grandes, frequentemente espatáceas (Ribeiro et al., 1999; Lorenzi e Souza, 2001).

Conhecida popularmente como trapoeraba-roxa, coração-roxo, trapoerabão ou trapoeraba, apresenta ampla distribuição e fácil adaptação, sendo cultivada em regiões tropicais e subtropicais. Considerando a Tradescantia como planta bioindicadora, o seu uso pode levar a identificação dos efeitos diretos sobre os organismos sejam eles anatômicos (Alves et al., 2001; Crispim et al., 2014), ou até mesmo no DNA (Sposito et al., 2017), sob forma de efeitos genotóxicos e/ou mutagênicos, sendo interpretadas como respostas adaptativas dos vegetais as condições ambientais.

\subsection{Testes utilizados com Tradescantia pallida}

\subsubsection{Testes anatômicos}

A concentração de elementos químicos não essenciais nas folhas está diretamente relacionada à deposição de partículas provenientes da poluição atmosférica por emissões veiculares, alterando a composição química foliar natural destas plantas. Sumita et al. (2003) avaliaram a capacidade de acumulação de oligoelementos provenientes da poluição atmosférica em folhas de T. pallida e indicaram o uso potencial desta planta no biomonitoramento de ambientes urbanos altamente poluídos. Santos et al. (2015) também mostraram que plantas expostas em áreas de alto fluxo veicular apresentaram maiores concentrações de elementos relacionados às emissões dos veículos, sendo consideradas sensíveis e um instrumento alternativo no biomonitoramento.

A exposição das plantas aos poluentes atmosféricos também pode alterar a frequência estomática, sendo desfavorável ao desenvolvimento fisiológico normal da planta como comprometimento da capacidade fotossintética devido a redução das trocas gasosas. Crispim et al. (2014) observaram que plantas de T. pallida situadas em áreas com alto fluxo veicular apresentaram maior número de células epidérmicas e densidade estomática. Estas observações indicaram que alterações estomáticas interferem na quantidade de poluentes gasosos absorvidos pela planta, sendo essencial para sua adaptação em condições adversas.

Segundo Alves et al. (2001) e Crispim et al. (2014) variações anatômicas, como espessura da folha e quantidade de estômatos, representam uma estratégia adaptativa a ambientes poluídos, dificultando o deslocamento dos poluentes para o interior da folha. No entanto, alterações na capacidade de trocas gasosas acarretam no comprometimento da taxa fotossintética e, consequentemente, do crescimento da planta, constituindo uma das formas mais sensíveis de medir o estresse em um organismo. Segundo Zeiger (2006), partículas em suspensão, ao atingirem as folhas, bloqueiam os estômatos, diminuindo a condutância de $\mathrm{CO}_{2}$, interferindo na taxa de fotossíntese e, consequentemente, no crescimento das plantas. 


\subsubsection{Testes genéticos}

Segundo Ma et al. (1994), o bioensaio de mutação em pelo estaminal (Trad-SHM) é baseado na detecção de mutações mitóticas. As células de pelos estaminais são heterozigotas, com um marcador fenotípico visível que muda a cor dos filamentos do estame de azul (dominante) para rosa (recessivo) quando expostos a poluentes que podem promover mutações baseadas na mudança de coloração nas células de pelos estaminais. De acordo com Patussi e Bündchen (2013), o teste Trad-SHM tem sido empregado na avaliação do risco ambiental para análise de contaminantes ambientais, sendo utilizado como biomarcador da qualidade ambiental.

O ensaio do cometa pode ser utilizado para detectar quebras na dupla fita de DNA em vários tipos de células utilizando eletroforese, com base na migração dos fragmentos de DNA livres resultantes de quebras para fora do núcleo. Desta maneira, o nível de dano genético das células está relacionado com a extensão dos fragmentos de DNA (Collins, 2004; Speit e Hartmann, 2005). Sposito et al. (2017), demonstraram que plantas expostas ao tráfego veicular intenso apresentaram maior número de danos genéticos em relação a plantas não sujeitas ao estresse ambiental por poluentes atmosféricos, indicando a eficácia da técnica na detecção de danos no DNA associados ao tráfego veicular.

Dentre as espécies vegetais, a Tradescantia pallida (Trad-MCN) tem sido amplamente empregada na detecção de danos cromossômicos em células-mãe de grãos de pólen na fase de tétrade. O teste consiste na estimativa da frequência de micronúcleos, sendo o número de micronúcleos proporcional à concentração de poluentes (De Andrade Júnior et al., 2008).

Micronúcleos correspondem a pequenas massas de cromatina derivadas de quebras cromossômicas (clastogênese) e/ou de aberrações cromossômicas numéricas (aneugênese) induzidas por agentes que danificam o cromossomo ou o fuso mitótico. Os fragmentos ou cromossomos inteiros não se ligam às fibras do fuso mitótico e não são incorporados no núcleo das células filhas durante a meiose. Segundo Carvalho (2005) cromossomos em divisão meiótica são mais sensíveis à quebra que os cromossomos em divisão mitótica. Desta forma, essas estruturas permanecem no citoplasma das células interfásicas e formam a própria membrana nuclear, originando micronúcleos, os quais se assemelham ao núcleo principal quanto à forma, estrutura e propriedades de coloração, e podem variar quanto ao tamanho (Ma et al., 1981; Holland et al., 2008; Meireles e Cerqueira, 2011).

$\mathrm{O}$ teste tem sido empregado em diversos trabalhos científicos apresentando vantagens como baixo custo financeiro, fácil acesso ao material e alta sensibilidade aos agentes genotóxicos, permitindo a avaliação do dano cromossômico em preparações citológicas simples e de rápida execução, sendo considerado ferramenta fundamental para a detecção de efeitos clastogênicos e aneugênicos (Klumpp et al., 2004; Pereira et al., 2013).

Sposito et al. (2017), em estudo de biomonitoramento passivo realizado em cidades do estado de Mato Grosso do Sul, demonstram que o teste Trad-MCN é uma excelente ferramenta para detecção de estressores ambientais, como os poluentes atmosféricos. Segundo Lima (2001), o monitoramento passivo, é baseado na utilização de organismos existentes naturalmente no local de pesquisa, e o ativo ocorre quando os organismos são introduzidos na área de estudo.

Considerando que o bioensaio Trad-MCN é considerado ferramenta abrangente no sentido biológico e geográfico, o presente estudo teve como objetivo realizar levantamento bibliográfico, aferindo regiões brasileiras monitoradas que utilizaram o teste de micronúcleo em Tradescantia (Trad-MCN). 


\section{MATERIAL E MÉTODOS}

Realizou-se levantamento bibliográfico de trabalhos científicos publicados e indexados, em sites de busca como: Portal de Períodicos CAPES, SciELO, ScienceDirect e PubMed, que utilizaram o teste Trad-MCN em Tradescantia como organismo bioindicador para monitoramento da qualidade do ar no Brasil. Para tanto, foram utilizadas as seguintes palavras-chave: poluição atmosférica, biomonitoramento, Tradescantia e micronúcleo. Foram incluídos apenas pesquisas de monitoramento em plantas expostas in situ.

Os trabalhos foram avaliados quanto ao período de monitoramento, região brasileira monitorada (Norte, Nordeste, Sul, Sudeste e Centro-oeste, e respectivos Estados), área de estudo (urbana/rural), fontes emissoras de poluição atmosférica (tráfego, atividade industrial, material particulado e queima de biomassa), planta utilizada no monitoramento (Tradescantia pallida ou clone híbrido 4430) e procedimentos de monitoramento (passivo/ativo). $\mathrm{O}$ monitoramento passivo consiste em utilizar plantas existentes naturalmente na área de estudo. $\mathrm{O}$ monitoramento ativo, por sua vez, refere-se às plantas introduzidas por determinado período ao local de pesquisa.

\section{RESULTADOS E DISCUSSÃO}

Os resultados do levantamento bibliográfico foram apresentados na Tabela 1.

O levantamento bibliográfico abrangeu diversas regiões do país. No entanto, verificou-se que a maioria dos estudos que utilizaram o bioensaio Trad-MCN como ferramenta de monitoramento da qualidade do ar ocorreram na região sudeste (43\%), especialmente no estado de São Paulo. Outro aspecto relevante foi a relação deste teste com o tráfego veicular e atividades industriais.

De acordo com estatísticas fornecidas pelo Departamento Nacional de Trânsito, o Brasil possui 90 milhões de veículos motorizados, dos quais 30\% (27.332.101) estão concentrados no Estado de São Paulo (Brasil, 2016), correspondendo a uma parcela significativa da frota veicular do país (Brasil, 2013). Segundo estimativa da CETESB (2004), veículos automotores produzem mais poluição atmosférica que qualquer outra atividade humana. Ambientes urbanos são áreas sob constante atividade humana e, consequentemente, elevada concentração de poluentes atmosféricos, provenientes de fontes móveis (frota de veículos automotores) e estacionárias (atividades industriais). Costa e Droste (2012) verificaram frequências de micronúcleo (MCN) superiores em área urbana com elevada frota veicular em comparação aos resultados observados na área rural.

Nas regiões urbanas, as emissões de poluentes por veículos contribuem para o aumento de partículas, que podem ser inaladas nos pulmões, aumentando os riscos para a saúde (Song e Gao, 2011). Desta forma, o maior número de trabalhos que avaliaram danos genéticos em T. pallida expostas ao tráfego veicular demonstraram a preocupação com essas fontes poluidoras e os danos por elas ocasionados à saúde da população. Neste cenário, o biomonitoramento por meio do bioensaio Trad-MCN pode ser utilizado como ferramenta de gestão prática na detecção e avaliação da poluição do ar, complementando métodos físicos e químicos (Sposito et al., 2015).

Apesar das fontes móveis serem responsáveis pela maior taxa de poluição atmosférica, Mariani et al. (2009), Savóia et al. (2009), Costa e Droste (2012), Teixeira e Barbério (2012), Barbério et al. (2013) e Campos et al. (2016) consideraram fontes estaciónarias como importantes meios de poluição atmosférica, e que devem ser monitoradas. O Estado de São Paulo representa o principal centro financeiro do país com o maior e mais completo parque industrial do Brasil, aproximadamente 63.708 indústrias (IBGE, 2014) 
Tabela 1. Trabalhos de monitoramento da qualidade do ar realizados em diferentes regiões brasileiras utilizando o bioensaio Trad-MCN.

\begin{tabular}{|c|c|c|c|c|c|c|}
\hline Autoria & Período de amostragem & Região/Estado & Área & Fontes emissoras & Ativo ou passivo & T. pallida /clone 4430 \\
\hline Guimarães et al. $(2000)^{\mathrm{a}}$ & Junho, agosto a dezembro (1998) & Sudeste (SP) & Urbana & Tráfego & Ativo e passivo & T. pallida \\
\hline de Andrade Júnior et al. (2008)a & Maio (2005) a março (2006) & Nordeste (BA) & Urbana & Tráfego & Ativo & T. pallida \\
\hline Mariani et al. $(2009)^{\mathrm{a}}$ & Maio a outubro (2006) & Sudeste (SP) & Urbana & Tráfego e indústria & Ativo & T. pallida \\
\hline Meireles et al. (2009) ${ }^{\mathrm{a}}$ & Fevereiro (2006) a dezembro (2007) & Nordeste (BA) & Urbana & Tráfego & Ativo e passivo & Clone \\
\hline Savóia et al. (2009)a & Setembro (2003) a setembro (2004) & Sudeste (SP) & Urbana & Tráfego e indústria & Ativo & T. pallida \\
\hline Sisenando et al. $(2011)^{\mathrm{a}}$ & Maio (2008) a abril (2009) & Centro-Oeste (MT) & Urbana & Queima de biomassa & Ativo e passivo & T. pallida \\
\hline Costa e Droste (2012) ${ }^{\mathrm{a}}$ & Um ano $(2009 / 2010)$ & Sul (RS) & Urbana e rural & Indústria & Ativo & T. pallida \\
\hline Crispim et al. $(2012)^{\mathrm{a}}$ & Março a agosto (2010) & Centro-Oeste (MS) & Urbana & Tráfego & Passivo & T. pallida \\
\hline Teixeira e Barbério (2012) ${ }^{\mathrm{a}}$ & Setembro (2010) a junho (2011) & Sudeste (SP) & Urbana e rural & Tráfego e indústria & Ativo & T. pallida \\
\hline Barbério et al. $(2013)^{\mathrm{a}}$ & Julho (2011) a junho (2012) & Sudeste (SP) & Urbana & Indústria & Ativo & T. pallida \\
\hline De Brito et al. $(2013)^{b}$ & Outubro a dezembro (2010) & Sul (RS) & Urbana & Material particulado & Ativo & T. pallida \\
\hline Pereira et al. $(2013)^{\mathrm{a}}$ & Inverno (2006) ao verão (2011) & Sudeste (MG) & Urbana & Tráfego & Passivo & T. pallida \\
\hline Blume et al. (2014) ${ }^{\mathrm{a}}$ & Dezembro (2011) a novembro (2012) & Sul (RS) & Urbana & Tráfego & Ativo & T. pallida \\
\hline Crispim et al. $(2014)^{\mathrm{a}}$ & Abril a setembro (2011) & Centro-Oeste (MS) & Urbana & Tráfego & Ativo & T. pallida \\
\hline Pereira et al. (2014) ${ }^{\mathrm{a}}$ & Maio (2010) & Sudeste (MG) & Urbana & Tráfego & Passivo & T. pallida \\
\hline Yaguinuma et al. (2014) ${ }^{\mathrm{a}}$ & Maio a setembro $(*)$ & Sudeste (SP) & Urbana & Tráfego & Ativo & T. pallida \\
\hline Santos et al. $(2015)^{\mathrm{a}}$ & Março a junho / agosto (2011) & Sudeste (SP) & Urbana & Tráfego & Ativo & T. pallida \\
\hline Sposito et al. $(2015)^{\mathrm{a}}$ & Maio a agosto $(2010-2012)$ & Centro-Oeste (MS) & Urbana & Tráfego & Ativo & T. pallida \\
\hline Cassanego et al. $(2015)^{\mathrm{a}}$ & Maio (2012) a março (2013) & Sul (RS) & Urbana & Tráfego & Ativo & T. pallida \\
\hline da Costa et al. $(2015)^{\mathrm{a}}$ & Abril (2012) a fevereiro (2014) & Sul (RS) & Urbana & Tráfego & Ativo & T. pallida \\
\hline Caon et al. $(2016)^{a}$ & Novembro (2012) a outubro (2013) & Sul (RS) & Urbana & Tráfego, indústria e agricultura & Ativo & T. pallida \\
\hline Campos et al. $(2016)^{\mathrm{a}}$ & Junho (2013) a agosto (2013) & Sudeste (MG) & Urbana & Indústria & Ativo & T. pallida \\
\hline da Costa et al. $(2016)^{\mathrm{a}}$ & Maio (2012) a fevereiro (2014) & Sul (RS) & Urbana & Tráfego & Passivo e ativo & T. pallida \\
\hline Sposito et al. $(2017)^{\mathrm{a}}$ & Março, maio, julho, setembro e novembro (2014) & Centro-Oeste (MS) & Urbana & Tráfego & Passivo & T. pallida \\
\hline
\end{tabular}

Nota: $\left({ }^{*}\right)$ Artigo não fornece dados sobre o ano de monitoramento. $\left({ }^{a}\right)$ Trabalhos que verificaram associação significativa entre frequência de micronúcleo e contaminação atmosférica. (b) Não foi verificado genotoxicidade pelo referido teste em locais com áreas poluídas.

Fonte: Guimarães et al., 2000; de Andrade Júnior et al., 2008; Mariani et al., 2009; Meireles et al., 2009; Savóia et al., 2009; Sisenando et al., 2011; Costa e Droste, 2012; Crispim et al., 2012; Teixeira e Barbério, 2012; Barbério et al., 2013; De Brito et al., 2013; Pereira et al., 2013; Blume et al., 2014; Crispim et al., 2014; Pereira et al., 2014; Yaguinuma et al., 2014; Santos et al., 2015; Sposito et al., 2015; Cassanego et al., 2015; da Costa et al., 2015; Caon et al., 2016; Campos et al., 2016; da Costa et al., 2016; Sposito et al., 2017 . 
O processo de industrialização aumenta significativamente a contaminação atmosférica por misturas complexas de poluentes atmosféricos, como partículas, óxidos de nitrogênio e carbono (Costa e Droste, 2012). Neste contexto, o monitoramento de regiões com intensa concentração industrial, como o estado de São Paulo, constitui ferramenta importante para avaliação dos impactos socioambientais da atividade industrial, além daqueles impactos resultantes da interação com demais atividades antrópicas.

Também foi verificada a relação entre frequência de micronúcleos e exposição a partículas finas oriundas da queima de biomassa. A queima de biomassa é um dos exemplos de atividade da ação humana relacionada ao aumento significativo da concentração de poluentes, causando efeitos adversos à qualidade do ar e consequentemente a saúde da população (Cançado et al., 2006; Magalhães et al., 2007). Sisenando et al. (2011) observaram relação entre o aumento da frequência de micronúcleos e o aumento da exposição a partículas finas ocasionadas pela queima da palha da cana-de-açúcar. Os autores ainda sugerem que T. pallida é um importante indicador biológico a ser incluído na avaliação do risco humano à exposição a agentes tóxicos.

O monitoramento pode ser realizado a partir de dois sistemas distintos: passivo, com a utilização de organismos naturalmente existentes em uma área, ou ativo, com exposição de organismos na área a ser avaliada por determinado tempo e em condições controladas (Lima, 2001). Estudos realizados por Meireles et al. (2009) e Guimarães et al. (2000), utilizando os dois sistemas de monitoramento, observaram que o ativo foi mais sensível aos poluentes e demonstrou maior ocorrência de micronúcleos em relação ao passivo. Verificaram que plantas existentes naturalmente no local de estudo, monitoramento passivo, podem se adaptar as condições ambientais as quais estão expostas, considerando assim o monitoramento ativo mais sensível, eficaz e amplamente utilizado nos estudos da qualidade do ar.

Os bioensaios desenvolvidos utilizando plantas e clones do gênero Tradescantia são considerados ferramentas valiosas para avaliar os efeitos mutagênicos de contaminantes ambientais. Por esta razão, desde os primórdios da toxicologia genética, várias espécies e clones do gênero Tradescantia têm sido utilizados como organismos bioindicadores em estudos e programas de biomonitoramento (Ma e Grant, 1982).

No Brasil, a Tradescantia pallida vem sendo utilizada em substituição ao clone 4430, fornecendo resultados satisfatórios. Resultados baseados em estudos comparativos obtidos por Mielli et al. (2009) demonstraram que ambas as plantas apresentaram resultados semelhantes. Desta forma a T. pallida pode substituir o clone 4430 no teste de micronúcleo. Considerando que o clone 4430 tem aplicações limitadas em países tropicais quanto ao clima e ataque de insetos, o que limita o seu uso para estudos de biomonitoramento (Sant'Anna, 2003), tais resultados justificam o maior número de trabalhos que utilizam a planta $T$. pallida ao invés do clone.

A T. pallida tem sido amplamente utilizada por ser considerada tão eficiente para estudos de biomonitoramento quanto as plantas geneticamente selecionadas. A utilização de plantas naturais oferece vantagens, como redução de custo, desenvolvimento em países com condição climática tropical e subtropical e maior resistência a pragas, já que estão biologicamente adaptadas (Batalha et al., 1999).

Diante do levantamento bibliográfico, verificou-se que todos os trabalhos de monitoramento utilizando o bioensaio Trad-MCN apresentaram relação significativa entre o número/frequência de micronúcleos e a contaminação atmosférica ocasionada por atividade industrial, tráfego veicular e queima de biomassa, com exceção do trabalho de De Brito et al. (2013), no qual não foi detectado genotoxicidade pelo referido ensaio em locais com áreas poluídas.

Segundo Santos et al. (2015), o bioensaio Trad-MCN pode servir como uma metodologia de suporte para a adoção de políticas públicas ambientais mais restritivas no Brasil e extensível a outros países em desenvolvimento. Além do mais, de acordo com Costa e Droste (2012),

Rev. Ambient. Água vol. 12 n. 3 Taubaté - May / Jun. 2017 
Teixeira e Barbério (2012), Crispim et al. (2014), Sposito et al. (2015) e Da Costa et al. (2016), propõe-se, que o ensaio Trad-MCN seja incluído como ferramenta adicional no monitoramento da qualidade do ar e complementar às análises químicas.

\section{CONSIDERAÇÕES FINAIS}

O levantamento bibliográfico permitiu concluir que a Tradescantia demonstra ser uma planta altamente sensível e um excelente organismo teste, sendo considerada uma ferramenta essencial no biomonitoramento de ambientes degradados.

Os resultados do levantamento referente ao uso do bioensaio Trad-MCN revelaram que poluentes atmosféricos oriundos de atividade industrial, tráfego veicular e queima de biomassa, apresentaram potencial estresse oxidativo em Tradescantia. Desta forma, sugere-se que a referida técnica seja utilizada como método complementar às análises químicas.

\section{AGRADECIMENTOS}

Os autores são gratos à Universidade Federal da Grande Dourados (UFGD) pelo seu apoio logístico, à Fundação de Apoio ao Desenvolvimento do Ensino, Ciência e Tecnologia do Estado de Mato Grosso do Sul (FUNDECT) e à Coordenação de Aperfeiçoamento de Pessoal de Nível Superior (CAPES).

\section{REFERÊNCIAS}

ALVES, E. S.; GIUSTI, P. M.; DOMINGOS, M.; SALDIVA, P. H. N.; GUIMARÃES, E. T.; LOBO, D. J. A. Estudo anatômico foliar do clone híbrido 4430 de Tradescantia: alterações decorrentes da poluição aérea urbana. Revista Brasileira de Botânica, v. 24, n. 4, p. 567-576, 2001. http://dx.doi.org/10.1590/S0100-84042001000500012

BARBÉRIO, A.; VOLTOLINI, J. C.; RIBEIRO, M. C. L. Efeitos mutagênicos da poluição atmosférica em Tradescantia pallida no distrito de Moreira César, em Pindamonhangaba, SP. Revista Biociências, v. 19, n. 1, p. 69-79, 2013.

BATAlHA, J. R. F.; GUIMARÃES, E. T.; LOBO, D. J. A.; LICHTENFELS, A. J. F. C.; DEUR, T. et al. Exploring the clastogenic effects of air pollutants in São Paulo (Brazil) using the Tradescantia micronuclei assay. Mutation Research/Fundamental and Molecular Mechanisms of Mutagenesis, v. 426, n. 2, p. 229-232, 1999. http://dx.doi.org/10.1016/S0027-5107(99)00073-1

BLUME, K. K.; COSTA, G. M.; CASSANEGO, M. B. B.; DROSTE, A. Genotoxicidade do ar em área urbana na região metropolitana de Porto Alegre, RS, Brasil. Revista Brasileira de Biociências, v. 12, n. 3, p. 158-163, 2014.

BRASIL. Departamento Nacional de Trânsito - DENATRAN. Frota de veículos no ano de 2013. 2013. Disponível em: http://www.denatran.gov.br/frota.htm. Acesso em: 10 nov. 2014.

BRASIL. Departamento Nacional de Trânsito - DENATRAN. Frota de veículos no ano de 2016. 2016. Disponível em: http://www.denatran.gov.br/frota.htm. Acesso em: 10 mar. 2017. 
CAMPOS, C. F.; CAMPOS JR., E. O. D.; SOUTO, H. N.; SOUSA, E. D. F.; PEREIRA, B. B. Biomonitoring of the environmental genotoxic potential of emissions from a complex of ceramic industries in Monte Carmelo, Minas Gerais, Brazil, using Tradescantia pallida. Journal of Toxicology and Environmental Health, v. 79, p. 123-128, 2016. http://dx.doi.org/10.1080/15287394.2015.1118714

CANÇADO, J. E.; SALDIVA, P. H.; PEREIRA, L. A.; LARA, L. B.; ARTAXO, P.; MARTINELLI, L. A. et al. The impact of sugar cane-burning emissions on the respiratory system of children and the elderly. Environmental health perspectives, v. 114, n. 5, p. 725-729, 2006. http://www.jstor.org/stable/3651044

CAON, K.; DA COSTA, G. M.; CASSANEGO, M. B. B.; DROSTE, A. Tradescantia pallida var. purpurea (Commelinaceae) e biomonitoramento da genotoxicidade do ar no município de Caxias do Sul, RS, Brasil. Pesquisas, Botânica, n. 69, p. 279-291, 2016.

CARNEIRO, R. M. A.; TAKAYANAGUI, A. M. M. Estudos sobre bioindicadores vegetais e poluição atmosférica por meio de revisão sistemática da literatura. Revista Brasileira de Ciências Ambientais, v. 13, p. 26-44, 2009.

CARVALHO, H. A. The Tradescantia as vegetable bioindicator in monitoring clastogenic effects of ionizing radiation. Radiologia Brasileira, v. 38, p. 459-462, 2005.

CASSANEGO, M. B. B.; SASAMORI, M. H.; PETRY, C. T.; DROSTE, A. Biomonitoring the genotoxic potential of the air on Tradescantia pallida var. purpurea under climatic conditions in the Sinos River basin, Rio Grande do Sul, Brazil. Brazilian Journal of Biology, v. 75, n. 4, p. 79-87, 2015. http://dx.doi.org/10.1590/1519-6984.05514

COLLINS, A. R. O cometa ensaio para danos ao DNA e reparação. Molecular biotechnology, v. 26, n. 3, p. 249, 2004.

CATINON, M.; AYRAULT, S.; DAUDIN, L.; SEVIN, L.; ASTA, J.; TISSUT, M.; RAVANEL, P. Atmospheric inorganic contaminants and their distribution inside stem tissues of Fraxinus excelsior L. Atmospheric environment, v. 42, n. 6, p. 1223-1238, 2008. http://dx.doi.org/10.1016/j.atmosenv.2007.10.082

COMPANHIA DE TECNOLOGIA DE SANEAMENTO AMBIENTAL - CETESB. Relatório anual de qualidade do ar no estado de São Paulo. São Paulo, 2004.

COSTA, G. M.; DROSTE, A. Genotoxicity on Tradescantia pallida var. purpurea plants exposed to urban and rural environments in the metropolitan area of Porto Alegre, southern Brazil. Brazilian Journal of Biology, v. 72, n. 4, p. 801-806, 2012. http://dx.doi.org/10.1590/S1519-69842012000500004

CRISPIM, B. A.; VAINI, J. O.; GRISOLIA, A. B.; TEIXEIRA, T. Z.; MUSSURY, R. M.; SENO, L. O. Biomonitoring the genotoxic effects of pollutants on Tradescantia pallida (Rose) D.R. Hunt in Dourados, Brazil. Environmental Science and Pollution Research, v. 19, n. 3, p. 718-723, 2012. http://dx.doi.org/10.1007/s11356-011-0612-3

CRISPIM, B. A.; SPOSITO, J. C.; MUSSURY, R. M.; SENO, L. O.; GRISOLIA, A. B. Effects of atmospheric pollutants on somatic and germ cells of Tradescantia pallida (Rose) DR HUNT cv. purpurea. Anais da Academia Brasileira de Ciências, v. 86, n. 4, p. 18991906, 2014. http://dx.doi.org/10.1590/0001-3765201420140338 
DA COSTA, G. M.; CASSANEGO, M. B. B.; PETRY, C. T.; SASAMORI, M. H.; ENDRESJÚNIOR, D.; DROSTE, A. Avaliação da influência do tempo de exposição de Tradescantia pallida var. purpurea para biomonitoramento da genotoxicidade do ar atmosférico. Revista Brasileira de Biociências, v. 13, n. 4, p. 224-230, 2015.

DA COSTA, G. M.; PETRY, C. T.; DROSTE, A. Active versus passive biomonitoring of air quality: Genetic damage and bioaccumulation of trace elements in flower buds of Tradescantia pallida. Water, Air, \& Soil Pollution, v. 227, n. 7, p. 1-12, 2016. http://dx.doi.org/10.1007/s11270-016-2923-y

DE ANDRADE JR., S. J.; SANTOS JR., J. C. S.; DA LUZ OLIVEIRA, J.; CERQUEIRA, E. D. M. M.; MEIRELES, J. R. C. Micronúcleos em tétrades de Tradescantia pallida (Rose) Hunt. cv. purpurea Boom: alterações genéticas decorrentes de poluição aérea urbana. Acta Scientiarum Biological Sciences, v. 30, n. 3, p. 295-301, 2008.

DE BRITO, K. C. T.; DE LEMOS, C. T.; ROCHA, J. A. V.; MIELLI, A. C.; MATZENBACHER, C.; VARGAS, V. M. F. Comparative genotoxicity of airborne particulate matter (PM2. 5) using Salmonella, plants and mammalian cells. Ecotoxicology and Environmental Safety, v. 94, n. 1, p. 14-20, 2013. http://dx.doi.org/10.1016/j.ecoenv.2013.04.014

DE SOUZA, C. P.; DE ANDRADE, G. T.; FONTANETTI, C. S. Evaluation of herbicides action on plant bioindicators by genetic biomarkers: a review. Environmental monitoring and assessment, v. 188, n. 12, p. 694, 2016. http://dx.doi.org/10.1007/s10661-016-5702-8

GUimarÃES, E. T.; DOMINGOS, M.; ALVES, E. S.; CALDINI, N.; LOBO, D. J. A.; LICHTENFELS, A. J. F. C. et al. Detection of the genotoxicity of air pollutants in and around the city of São Paulo (Brazil) the Tradescantia-micronucleus (Trad-MCN) assay. Environmental and Experimental Botany, v. 44, n. 1, p. 1-8, 2000. http://dx.doi.org/10.1016/S0098-8472(00)00050-2

HOLLAND, N.; BOLOGNESI, C.; KIRSCH-VOLDERS, M.; BONASSI, S.; ZEIGER, E.; KNASMUELLER, S. et al. The micronucleus assay in human buccal cells as a tool for biomonitoring DNA damage: the HUMN project perspective on current status and knowledge gaps. Mutation Research/Reviews in Mutation Research, v. 659, n. 1, p. 93-108, 2008. http://dx.doi.org/10.1016/j.mrrev.2008.03.007

INSTITUTO BRASILEIRO DE GEOGRAFIA E ESTATÍSTICA - IBGE. Pesquisa industrial anual: empresa. 2014. Disponível em: http://www.ibge.gov.br/estadosat/temas.php? sigla $=$ sp\&tema=piaempresa2014. Acesso em: 10 mar. 2017.

KLUMPP, A.; ANSEL, W.; FOMIM, A.; SCHNIRRING, S.; PICKL, C. Influence of climatic condition the mutations in pollen mother cells of Tradescantia clone 4430 and implications for the Trad-MCN bioassay protocol. Hereditas, v. 141, n. 2, p. 142-148, 2004. http://dx.doi.org/10.1111/j.1601-5223.2004.01806.x

LIMA, J. S. A. Utilização de bioindicadores de poluição em condições temperadas e tropicais. In: MAIA, N. B. M.; MARTOS, H. L.; BARELLA, W. (Org.). Indicadores ambientais: conceitos e aplicações. São Paulo: Educ/Comped/Inep, 2001.

LORENZI, H.; SOUZA, H. M. Plantas ornamentais no Brasil: arbustivas, herbáceas e trepadeiras. Nova Odessa: Instituto Plantarum, 2001. 
MA, T. H.; SPARROW, A. H.; SCHAIRER, L. A.; NAUMAN, A. F. Effect of 1,2dibromoethane (DBE) on meiotic chromosomes of Tradescantia. Mutation Research/Genetic Toxicology, v. 58, n. 2-3, p. 251-258, 1978. https://doi.org/10.1016/0165-1218(78)90016-2

MA, T. H. Tradescantia micronucleus bioassay and pollen tube chromatid aberration test for in situ monitoring and mutagen screening. Environmental Health Perspectives, v. 37, p. 85,1981 .

MA, T. H.; GRANT, W. F. The Tradescantias: adventurous plants. Herbarist, n. 48, p. 36-44, 1982.

MA, T. H.; CABRERA, G. L.; CHEN, R.; GILL, B. S.; SANDHU, S. S.; VANDENBERG, A. L. et al. Tradescantia micronucleus bioassay. Mutation Research/Fundamental and Molecular Mechanisms of Mutagenesis, v. 310, n. 2, p. 221-230, 1994. http://dx.doi.org/10.1016/0027-5107(94)90115-5

MAGAlHÃES, D.; BRUNS, R. E.; VASCONCELlOS, P. C. Polycyclic aromatic hydrocarbons as sugarcane burning tracers: a statistical approach. Química Nova, v. 30, n. 3, p. 577-581, 2007. http://dx.doi.org/10.1590/S0100-40422007000300014

MARIANI, R. L.; JORGE, M. P. M.; PEREIRA, S. S.; MELIONE, L. P.; CARVALHOOLIVEIRA, R.; SALDIVA, P. H. N. Association between micronuclei frequency in pollen mother cells of Tradescantia and mortality due to cancer and cardiovascular diseases: A preliminary study in Sao Jose dos Campos, Brazil. Environmental Pollution, v. 157, n. 6, p. 1767-1770, 2009. http://dx.doi.org/10.1016/j.envpol.2009.02.023

MEIRELES, J.; ROCHA, R.; COSTA NETO, A.; CERQUEIRA, E. Genotoxic effects of vehicle traffic pollution as evaluated by micronuclei test in Tradescantia (Trad-MCN). Mutation Research/Genetic Toxicology and Environmental Mutagenesis, v. 675, n. 1, p. 46-50, 2009. http://dx.doi.org/10.1016/j.mrgentox.2009.02.005

MEIRELES, J. R. C.; CERQUEIRA, E. M. M. Use of the Micronucleus Test on Tradescantia (Trad-MCN) to Evaluate the Genotoxic Effects of Air Pollution. In: MOLDOVEANU, A. M. (Ed.). Air pollution: new developments. [S.1.]: InTech, 2011. http://dx.doi.org/10.5772/17959MIELLI, A. C.; MATTA, M. E. M.; NERSESYAN, A.; SALDIVA, P. H. N.; UMBUZEIRO, G. A. Comparação entre as Respostas do Clone 4430 e Tradescantia pallida no Teste de Micronúcleos (Trad-MN). Journal of the Brazilian Society of Ecotoxicology, v. 4, n. 1-3, 49-54, 2009.

PATUSSI, C.; BÜNDCHEN, M. Avaliação in situ da genotoxicidade de triazinas utilizando o bioensaio Trad-SHM de Tradescantia clone 4430. Revista Ciência \& Saúde Coletiva, v. 18, n. 4, p. 1173-1178, 2013.

PEREIRA, B. B.; DE CAMPOS JÚNIOR, E. O.; MORELLI, S. In situ biomonitoring of the genotoxic effects of vehicular pollution in Uberlândia, Brazil, using a Tradescantia micronucleus assay. Ecotoxicology and environmental safety, v. 87, p. 17-22, 2013. http://dx.doi.org/10.1016/j.ecoenv.2012.10.003 
PEREIRA, B. B.; DE CAMPOS JR, E. O.; DE LIMA, E. A. P.; BARROZO, M. A. S.; MORELLI, S. Biomonitoring air quality during and after a public transportation strike in the center of Uberlândia, Minas Gerais, Brazil by Tradescantia micronucleus bioassay. Environmental Science and Pollution Research, v. 21, n. 5, p. 3680-3685, 2014. http://dx.doi.org/10.1007/s11356-013-2335-0

RIBEIRO, J. E. L. S.; HOPKINS, M. J. G.; VICENTINI, A.; SOTHERS, C. A.; COSTA, M. A. S.; BRITO, J. M. et al. Flora da Reserva Ducke: Guia de identificação das plantas vasculares de uma floresta de terra firme na Amazônia Central. Manaus: INPA-DFID, 1999.

SANT'ANNA, E. T. G. Poluição atmosférica urbana na cidade de São Paulo e mutagênese: avaliação de riscos utilizando-se bioindicadores vegetais do gênero Tradescantia, 2003. Tese (Doutorado em Fisiopatologia Experimental) - Universidade de São Paulo, São Paulo, 2003.

SANTOS, A. P. M.; SEGURA-MUÑOZ, S. I.; NADAL, M.; SCHUHMACHER, M.; DOMINGO, J. L.; MARTINEZ, C. A. et al. Traffic-related air pollution biomonitoring with Tradescantia pallida (Rose) Hunt. cv. purpurea Boom in Brazil. Environmental monitoring and assessment, v. 187, n. 2, p. 1-10, 2015. http://dx.doi. org/10.1007/s10661-014-4234-3

SAVÓIA, E. J. L. Potencial de Trandescantia pallida cv. purpurea para biomonitoramento da poluição aérea de Santo André. 2007. Tese (Doutorado em Fisiopatologia Experimental) - Faculdade de Medicina, Universidade de São Paulo, São Paulo, 2007.

SAVÓIA, E. J. L.; DOMINGOS, M.; GUIMARÃES, E. T.; BRUMATI, F.; SALDIVA, P. H. $\mathrm{N}$. Biomonitoring genotoxic risks under the urban weather conditions and polluted atmosphere in Santo André, SP, Brazil, through Trad-MCN bioassay. Ecotoxicology and Environmental Safety, v. 72, n. 1, p. 255-260, 2009. http://dx.doi. org/10.1016/j.ecoenv.2008.03.019

SISENANDO, H. A.; DE MEDEIROS, S. R. B.; SALDIVA, P. H.; ARTAXO, P.; HACON, S. S. Genotoxic potential generated by biomass burning in the Brazilian Legal Amazon by Tradescantia micronucleus bioassay: a toxicity assessment study. Environmental Health, v. 10, n. 1, p. 1, 2011. http://dx.doi.org/10.1186/1476-069X-10-41

SONG, F.; GAO, Y. Size distributions of trace elements associated with ambient particular matter in the affinity of a major highway in the New Jersey-New York metropolitan area. Atmospheric Environment, v. 45, n. 37, p. 6714-6723, 2011. http://dx.doi. org/10.1016/j.atmosenv.2011.08.031

SPEIT, G.; HARTMANN, A. The comet assay: a sensitive genotoxicity test for the detection of DNA damage. Molecular toxicology protocols, v. 291, p. 85-95, 2005. http://dx.doi.org/10.1385/1-59259-840-4:085

SPOSITO, J. C. V.; CRISPIM, B. A.; MUSSURY, R. M.; GRISOLIA, A. B. Genetic instability in plants associated with vehicular traffic and climatic variables. Ecotoxicology and environmental safety, v. 120, p. 445-448, 2015. http://dx.doi.org/10. 1016/j.ecoenv.2015.06.031 
SPOSITO, J. C. V.; CRISPIM, B. A.; ROMÃN, A. I.; MUSSURY, R. M.; PEREIRA, J. G.; SENO, L. O. et al. Evaluation the urban atmospheric conditions in different cities using comet and micronuclei assay in Tradescantia pallida. Chemosphere, v. 175, p. 108-113, 2017. http://dx.doi.org/10.1016/j.chemosphere.2017.01.136

SUMITA, N. M.; MENDES, M. E.; MACCHIONE, M.; GUIMARAES, E. T.; LICHTENFELS, A. J. D. F. C.; LOBO, D. J. D. A. et al. Tradescantia pallida cv. purpurea boom in the characterization of air pollution by accumulation of trace elements. Journal of the Air \& Waste Management Association, v. 53, n. 5, p. 574-579, 2003. http://dx.doi.org/10.1080/10473289.2003.10466197

SUYAMA, F.; GUIMARÃES, E. T.; LOBO, D. J.; RODRIGUES, G. S.; DOMINGOS, M.; ALVES, E. S. et al. Pollen mother cells of Tradescantia clone 4430 and Tradescantia pallida var. purpurea are equally sensitive to the clastogenic effects of X-rays. Brazilian Journal of Medical and Biological Research, v. 35, n. 1, p. 127-129, 2002. http://dx.doi.org/10.1590/S0100-879X2002000100018

TEIXEIRA, M. C. V.; BARBÉRIO, A. Biomonitoramento do ar com Tradescantia pallida (Rose) DR Hunt var purpurea Boom (Commelinaceae). Revista Ambiente \& Água, v. 7, n. 3, 2012. http://dx.doi.org/10.4136/ambi-agua.982

WHITE, P. A.; CLAXTON, L. D. Mutagens in contaminated soil: a review. Mutation Research/Reviews in Mutation Research, v. 567, n. 2, p. 227-345, 2004. http://dx.doi.org/10.1016/j.mrrev.2004.09.003

YAGUINUMA, D. H.; BRITO, L. G. L.; FLUMINHAN, A. Avaliação dos danos genéticos provocados por radiação solar e poluição aérea através da análise de micronúcleos em Tradescantia pallida cv purpurea. Fórum Ambiental da Alta Paulista, v. 10, n. 12, p. 255-269, 2014. http://dx.doi.org/10.17271/1980082710122014919

ZEIGER, E. The effect of air pollution on plants. In: TAIZ; L.; ZEIGER, E. Plant Physiology. $5^{\text {th }}$ ed. Sunderland: Sinauer, 2006. 